ANTI-CALVINIST? CEREMONIAL CONFORMITY AND LAUDIAN WRITING,

RECONSIDERED (c. 1590-1640)

\author{
A Dissertation \\ presented to
}

the Faculty of the Graduate School

at the University of Missouri-Columbia

In Partial Fulfillment

of the Requirements for the Degree

Doctor of Philosophy

By

TRAVIS KNAPP

Dr. Anne Myers, Dissertation Supervisor

May 2021 
The undersigned, appointed by the dean of the Graduate School, have examined the dissertation entitled

\section{ANTI-CALVINIST? CEREMONIAL CONFORMITY AND LAUDIAN WRITING,} RECONSIDERED (c. 1590-1640)

presented by Travis Knapp,

a candidate for the degree of doctor of philosophy,

and hereby certify that, in their opinion, it is worthy of acceptance.

Professor Anne Myers

Professor John Frymire

Professor William Kerwin

Professor David Read 


\section{ACKNOWLEDGEMENTS}

The intellectual and emotional debts I have accrued while completing this project are many.

While personal relationships tend to be relegated to the end of the acknowledgements, I begin with them. I would like to start by thanking my parents for their unfailing and unending support. I have been extremely fortunate to have such loving parents who have offered encouragement and support at every step of my life, which has made my graduate school experience much more comfortable, even amidst the various struggles and chaos that emerge in the process. Part of the reason I chose to attend the University of Missouri was to stay close to my family, and being within driving distance to my parents, my brothers and their families, has made the far-too-short holiday breaks quite enjoyable and pleasant.

Although I am sure I will inevitably omit meaningful friendships I have made over the years, no other has meant so much to me during grad school as my dear friend Allie's. I never would have imagined this friendship would have outlasted jokes about HR tabs and quips about who has played DnD more recently (not me) and turned into something so meaningful. From my trivial text rantings to her presence and support for me, especially when I began this project, which coincided with one of the lowest emotional points of my life, I cannot express my thankfulness enough for her friendship. Similarly, I hope in a few years I will be able to repay the favors to another friend from my undergraduate years, Allison, who was happy to listen to me vent about the ups and downs of the job market. While I have known Maggie since she began her master's at 
Mizzou, I only met her husband Joel this past year, when they moved into the house in front of mine. I have appreciated their friendship, camaraderie, and support (in long porch chats and leftover baked goods) as I finished this dissertation.

I have been fortunate to receive much institutional and professional support over the course of this project. Through Mizzou's participation in the Newberry Library Consortium, I have been lucky to attend workshops and receive research support from the Newberry and the Folger Shakespeare Libraries, the staff of which at both institutions have encouraged this project from its infancy. In addition to my assistantship, this project was funded in part by two fellowships, the MU English Department's Harry J. and Richard A. Hocks Dissertation Fellowship and the University of Missouri Graduate School's Raymond White Dissertation Year Fellowship. For finishing this project during a pandemic, the support has been instrumental, even if I did have to postpone a research trip to the UK.

This work has benefited from many mentorships and academic relationships over the year. I probably would never have gone to graduate school in English if not for the support of Edward Jones, whose research mentorship got me into the early modern period and without whom, I doubt I would have come across or recognize the name Lancelot Andrewes, whose writings and sermons got me into this research path. Almost every chapter of this dissertation was workshopped by the MU English Department's Critical Writing Workshop. My thanks to Emma Lipton, Nicole Songstad, Johanna Kramer, Elijah Guerra, McKenzie Peck, Thanh Nguyen, and Peter Land for their comments on various drafts and getting this project into decent argumentative shape. The professional 
mentorship of Steve Karian and Becca Hayes has helped me immensely in terms of refining my textual scholarship and preparing myself for the academic job market.

Lastly, the support and rapport of my dissertation committee has done much in terms of improving my ability as a scholar. Their genial attitudes and warmth in humoring my questions made all of the required meetings and examinations something to enjoy and look forward to rather than fear. To John Frymire, I appreciate the casual reminders that, for as much as England is on an island, early modern Protestantism was not so insular. To Bill Kerwin, I appreciate the early opportunities to explore Laudian poetics in your seminars and your enthusiasm in learning about what I have to contribute to the study of the religious landscape of $17^{\text {th }}$-century Britain. To David Read, I am thankful for your critical eye that has helped improve my prose and argumentation and for the reminders that I need to be more mindful of the puritans. And finally, to my adviser Anne Myers, I am thankful for everything: for constant encouragement, for the willingness to allow me to come into her office and ramble about my projects for hours at a time while still helping me narrow my focus, and support in reading and commenting on every abstract, application, and draft I have written these last seven years. I would not have had the academic success if not for her support as well as everyone else mentioned (and those I may unfortunately omitted).

And, to end the way all academic acknowledgements end: my work has been made better by the care and support of all mentioned here. Any shortcomings and errors that remain, quite naturally, are my own. 


\section{TABLE OF CONTENTS}

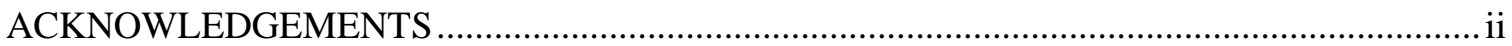

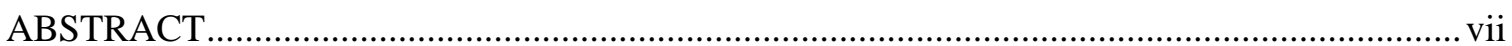

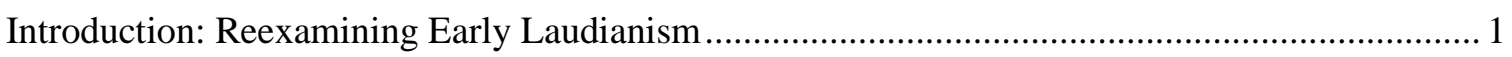

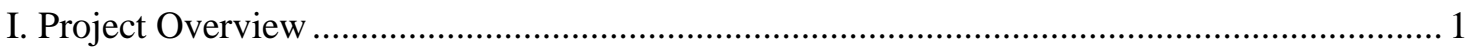

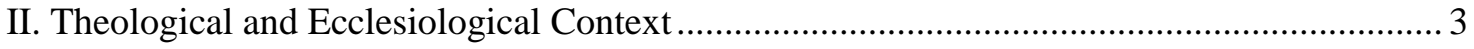

III. Laudianism, Avant-Garde Conformity, and Calvinism .................................................. 9

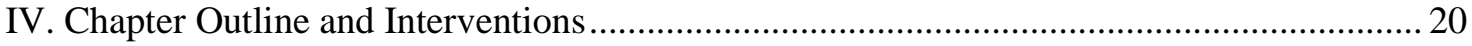

Chapter One: "I came hither to Preach, not to dispute" - Oratory and Polemic in 1618 Court Sermons

I. "We bethinke our selves: how to doe him Service. . Reverently to performe holy dueties:

Laudably to have our conversation among men" $(2,25-6)$.

II. The Duties of the whole man: "Give me leave to joyne these three, Adoration,

Prostration and Kneeling together: because in trueth they should never be separated" (10) .... 50

III. "The custome of Easter made a contention, would make it an Easter day Text" (1) ......... 61

Chapter Two: Merely Popish? John Cosin and his "barking Libellers" ........................................ 77

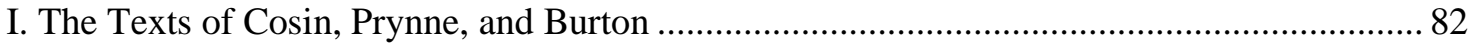

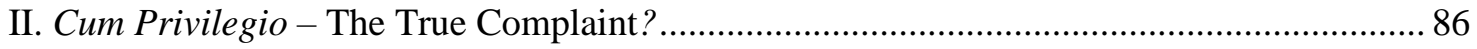

III. A Different Type of Altar Controversy - a Jesuit Frontispiece? ........................................ 89

IV. Whose Tradition? Catholic and Protestant Sources in Cosin's Primer Material ................. 95

V. Daniel Featley: A Case-study in English Protestant Conformity.

VI. "And if this bee superstition, what is Religion?" (536): Addressing the Controversies of

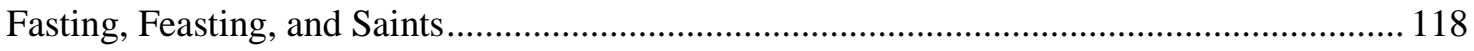

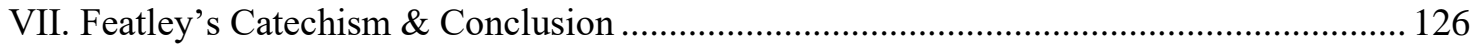

Chapter Three: Laudianism in Private Devotionals, 1612-1631 ................................................ 136

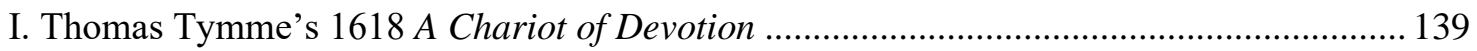

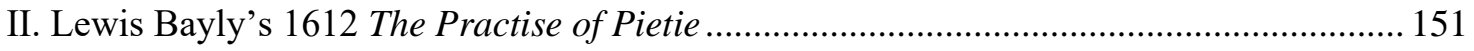

III. Exeter: Henry Tozer's 1628 Directions for a Godly Life and Charles Herle's 1631

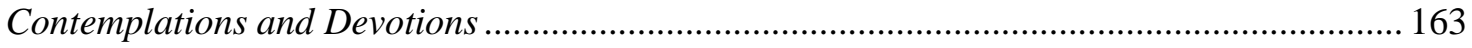

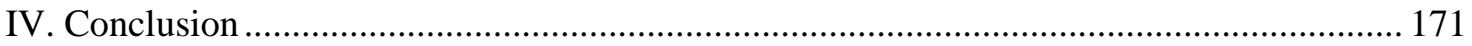

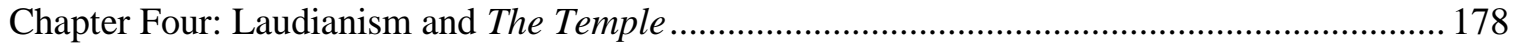

I. "The Dedication” and The Church-porch: Ceremonial Preparation?.................................... 182 
II. Inside The Church: Holy Week, Liturgy, and Preparing for the Sacrament ....................... 192

III. Initial Culminations? A Superficial Easter and a Sacramental Sequence......................... 203

IV. Enflaming the Broken Heart: the Artistic Interlude and Poetry Sequence ....................... 221

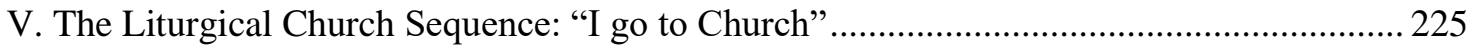

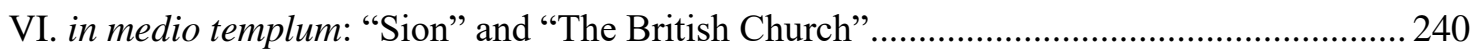

VII. The Apocalyptic Culmination: "The Invitation" to "sit and eat" ...................................247

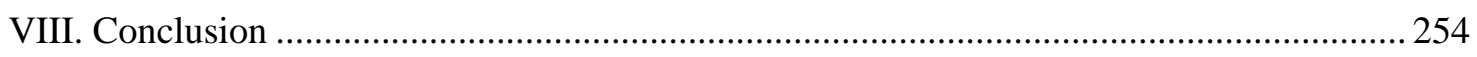

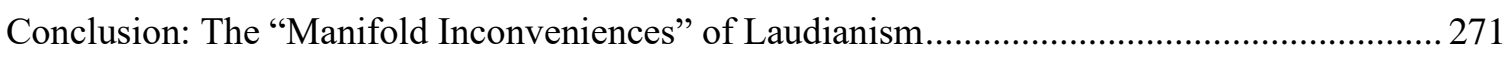

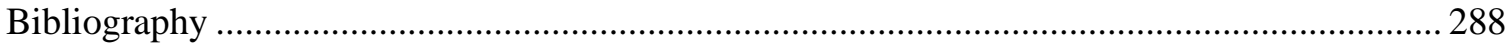

VITA 


\title{
ANTI-CALVINIST? CEREMONIAL CONFORMITY AND LAUDIAN WRITING, RECONSIDERED (c. 1590-1640)
}

Travis Knapp

Dr. Anne Myers, Dissertation Supervisor

\begin{abstract}
In recent studies of religion in early modern England, scholars have come to the consensus that the religious identity of the Church of England was never quite as stable or uniform as commonly perceived, with a wide variety of religious beliefs and practices coexisting in practice and print. While a significant portion of work has been done exploring the various ranges of puritan thought, diminishing the restrictive stereotypes of the often-derogatory label, less work has been done on the Laudians, a group of English churchmen known for their ceremonial worship practices, often considered to be uniformly anti-Calvinist or anti-puritan, marked partially by their (exclusive) emphasis on external markers of worship. This dissertation examines a wide range of Laudian texts, most published between 1610 and 1633 across the genres of court sermons, private devotionals, polemics, and poetry, to explore the various nuances of Laudianism. It argues that, in practice and especially before William Laud became Archbishop of Canterbury, the religious ideology now called Laudianism was less exclusive and authoritarian than commonly assumed. Rather than target Calvinist critics to force conformity in gesture, sacramental and liturgical observance, Laudian writers seek to reform religious behavior amenably. While Laudians do emphasize external worship practices, these practices are informed by internal markers of piety, where the external shows of worship become meaningless if the worshippers' hearts and souls are not oriented to the worship and service they display with their bodies.
\end{abstract}


Introduction: Reexamining Early Laudianism

“The description 'Laudian', however, can be vague and unhelpful, and obscure more than clarify."

"'Laudian' is not at all easy either to define or to apply. Moreover, there are those who deny that Laud was a Laudian."

\section{Project Overview}

This dissertation, with chapters organized by genre, examines religious identity within the Church of England during the early seventeenth century. Revisionist church history has argued that, against a widespread Calvinist consensus, a small cadre of court preachers, initially thought to have united around issues of Arminianism, advanced certain practices under King James I that paved the way for the ecclesiastical policies, now known as Laudianism, of King Charles I and his archbishop William Laud. This historiography has redefined English puritanism, lessening its association with overzealous preachers occupying a fringe position of Calvinist thought. While this work has done much to show the diversity of thought within the English Church, Laudianism largely remains on the opposite fringe, pairing rigid enforcement of ceremonial conformity in the 1630 s with a pervasive anti-Calvinist bias as the most definitive features - never mind that the belief in free-will or double predestination has little to do, inherently, with ceremonial or liturgical practices. This project seeks to show a similar flexibility existing in Laudian thought, revealing its moderation and undoing misconceptions blurred by scholarly skepticism that fails to take Laudians at their word and over-extends Civil War attitudes beyond their chronological scope. ${ }^{2}$ My definitions 
of Laudianism come from the primary sources themselves, with a concerted effort to emphasize generic and occasional contexts that shaped their formation.

Because the term Laudian carries an implicit anti-Calvinist bias, I try to separate each genre from polemical biases that may distort how we read the individual texts. For instance, church historians tend to cull most heavily and almost interchangeably from theological tracts, polemics, and sermons. In Chapter One, I argue that while printed sermons can have polemical subtexts, to use them chiefly as doctrinal statements - rather than attempts to stir hearers into religious action - undercuts a significant aim of the genre. For evidence, I use three sermons by Lancelot Andrewes and John Buckeridge. These sermons were delivered across the span of six months and published by royal command in 1618, a formative year in the evolution of James's religious policy. The second and third chapters turn to devotional literature, some of which provide models for devotion while others are more argumentative in nature. Chapter Two looks at perhaps the most contested devotional printed in the seventeenth century, John Cosin's $A$ Collection of Private Devotions, published in 1627 and met immediately with strong puritan criticism from William Prynne and Henry Burton. I explore the polemical potential of this devotion but argue that the responses are based on deliberate misreadings of Cosin's work that may stem more from the politics of the press than his articulated beliefs. I juxtapose Cosin's devotional with Daniel Featley’s Ancilla Pietatis (1625-6), a text that had much in common with Cosin's work but received less criticism. This similarity suggests that it was not the theological content of Cosin's work that attracted controversy. Chapter Three surveys other devotionals first published between 1612-1635 to explore how a variety of authors packaged Laudian practices for the masses away from 
the Stuart court. The fourth chapter examines George Herbert's The Temple, published in 1633, the year Laud became Archbishop of Canterbury. Few poets have had their precise beliefs scrutinized as much as Herbert, and literary scholars may be the ones that most advance the strict dichotomy between Calvinist and Laudian thought (with Laudian here being conflated with Anglo-Catholic and medieval traditions). I argue that an inclusive view of Laudianism - not one that separates it from the mainstream of English Protestantism - helps explain what has been identified as contradictory impulses in Herbert's poetry. Herbert's use of ceremony does not elevate ceremony for its own sake (as some presume of Laudianism) but frames it as a tool to advance one's own pious practices and inward reflections. Laudianism, then, is not a set of beliefs based upon exclusion, but incorporation. It seeks to unify English Reformed thought with the longstanding traditions of the universal Christian church. In the conclusion, I compare some of these "pre-Laud" attitudes with writings of Laud himself to show that, even at its most political, the tenets of Laudianism were consistent with its earlier conceptualizations.

\section{Theological and Ecclesiological Context}

If historical scholarship seeks to clarify the past, there must be a certain irony to the premise of the 2017 Oxford History of Anglicanism, wherein the editors state that "the Church of England . . . was always a contested identity." In the sixteenth and seventeenth centuries, the state of the Church "can appear a confusing muddle." 3 In terms of religious identity, this is progress. Revisionist scholarship from the 1980s has challenged the longstanding tradition of viewing the post-Reformation English Church as being split between its Anglican and puritan sides. ${ }^{4}$ This binary has a few potential sources. It may 
stem from the English Civil Wars, with an assumption of Anglican royalists and Commonwealth puritans, labels that people apply beyond the chronological scope of the mid-seventeenth century. In the $19^{\text {th }}$ century, the Anglo-Catholic Oxford Movement with its Library of Anglo-Catholic Theology promoted an ideology of the Anglican via media, with the English Church exemplifying the idealized compromise between Catholic Rome and Calvinist Geneva. To these Victorian scholars, the early seventeenth-century divines (anachronistically called Caroline) paved the way for the Anglicanism, cemented through the Restoration and its revision to the Book of Common Prayer. ${ }^{5}$ In the past forty years, puritanism has been found to be less unified, radical, and fringe than commonly believed, with the identification of moderate and conforming Puritans calming the identity once reserved for radical Calvinists. ${ }^{6}$ On the other hand, Puritanism's supposed ideological opposite within the Church of England, Laudianism, has not received the same treatment. ${ }^{7}$ My project seeks to reclaim early Laudianism from its connotations of radicalism to show its own appeals to moderation.

In its most technical sense, Laudianism refers to a set of church reforms, enforced by Archbishop William Laud and King Charles I. However, many of the tenets of Laudianism predate Laud's tenure as archbishop (1633-1645) and extend beyond the physical layout of the church. I maintain that Laudianism gets the short-shrift when it comes to scholarship (especially, but not exclusively, by literary scholars). ${ }^{8}$ Whereas views of English Protestantism have widened, Laudianism has stayed as an extreme, with the political Laudianism of the 1630 s taken as exemplar. ${ }^{9}$ This view of Laudianism sees the "beauty of holiness" campaign as one that is focused wholly on the externals of worship - with the placement of the altar, altar rails, and kneeling at communion as the 
defining factors of Laudianism. ${ }^{10}$ True, Charles and Laud enacted these policies in the 1630s and were immediately condemned as extreme, most notably by William Prynne whose puritanism seems almost sui generis. ${ }^{11}$ But these men did not come up with these policies in a vacuum. Their beliefs, perhaps most broadly described as a ceremonial conformity to the Book of Common Prayer, did not originate in an attempt to frame worship in exclusively external terms, as is often claimed. Peter Lake coined the term "Avant-Garde Conformity," which is often taken to be the precursor to Laudianism, to describe the (primarily) Jacobean churchmanship of bishops Lancelot Andrewes (16051626) and John Buckeridge (1611-1631). ${ }^{12}$ While their beliefs may have been more focused on gesture than the alleged "Calvinist consensus,"13 the (proto-)Laudian push towards beautification of the church and gesture, I argue, relied upon - or, maybe, took for granted - traditional notions of inward piety that are otherwise associated with Calvinist modes of worship. ${ }^{14}$

This dissertation seeks to broaden the view of Laudianism, relying especially on those works published before Laud became Archbishop in $1633 .{ }^{15}$ The quest to define Laudianism may indeed, to borrow a phrase of Anthony Milton's, be a “quixotic enterprise" due to the wide range of opinions found in the 130 years of the Church of England after its break from Rome and before the Restoration of Charles II. ${ }^{16}$ Although English religion may not become "Anglican" or systematically uniform until 1662 with the revision to the Book of Common Prayer (hereafter $B C P$ ), the attempt to understand the ideology behind what is often a dismissive sobriquet has its benefits, especially in an attempt to escape reductive stereotypes imposed by nomenclature. The dismissive attitudes toward Laudianism promote an assumption that the political regime under Laud 
and Charles - when Laudianism was at its most rigidly external - encapsulates all periods of Laudian belief, when, in reality, most earlier forms of Laudianism (with a notable exception for John Cosin's behavior at Durham) rely on a churchmanship that is meant to be more inclusive, moderate, and based on inward attitudes. I argue that conceptualizing Laudianism only as it existed in the 1630 s and 1640 s is restrictive and counterproductive in the same way that assuming all puritans were unanimous in their dissent for the church's authority and prayerbook. The Laudian brand of conformity, which upholds the authority of the church to implement worship practices, was in line with other English Protestants of the period. While Laudians may have brought more attention to the role of gesture, it was not for the sake of ostentation itself, but for a physical representation of the reverence and godliness demanded in worship. Gesture was an acknowledgement of humanity's humility and low status before the divine. That acknowledgement took place in the believer's heart before their knee and body could express it.

Typical of works on religious identity in this period, my references to Laudianism require an explanation of nomenclature and a disclaimer that there may be no sufficient and accurate label to account for the myriad beliefs in the pre-Restoration Church of England. Much like Anglicanism, Laudianism has anachronistic elements, as the term was coined well after Laud's death. ${ }^{17}$ Admittedly, I use Laudian freely, if out of necessity - arguing for an inclusive ideology results in a relative laxity in terminology, especially when trying to escape the term's narrowest uses to show that the religious landscape is different than has been understood. (Plus, Laudian is the shortest of its various synonyms). Part of my argument is that in the 1630s Laudianism sees a tonal and political shift, though other scholars do not distinguish between pre- or post-1633 Laudianism. 
Perhaps another term would be better. Peter Lake's "Avant-Garde Conformity” comes close to filling this gap, but its ideological telos still culminates in Laudianism. ${ }^{18}$ Lake's term is, in effect, a chronological euphemism, where the chronology remains specific to the Elizabethan and Jacobean church, but the beliefs are practically Laudian. ${ }^{19}$ As mentioned, the religion of the English Reformation was at no point uniform or systematic. The irony and challenge of arguing for the inclusive origins of Laudianism is that later, political Laudianism (like earlier notions of puritanism) destabilizes more than it unifies. ${ }^{20}$ To be clear, I am not suggesting that pre-political Laudianism is a substitute or origin for the idealized Anglican via media (though as a site of moderation, Laudianism does evoke certain elements of that ideology), but rather early Laudian beliefs, contrary to its anti-Calvinist stereotype, appeal to a wide range of English Protestants. $^{21}$

One of the more divisive conflicts in this period was over the role of tradition and whose tradition the English Church was continuing. Spinks's classification of "Patristic Reformed Churchmen" encapsulates the Laudian belief that the English church is continuing the tradition of the Ancient or Primitive Church. ${ }^{22}$ While it acknowledges that the Roman Church has erred, the English Reformation restored those flawed elements to reverent worship. The puritan counterpart argues the Reformed tradition truly begins in the sixteenth century (though it canonizes some early reformers like Tyndale or Wycliffe) and thus the Catholic (or even Jewish) continuity is heretical. ${ }^{23}$ Even in its early days in the early-to-mid sixteenth century, the English Church struggled reconciling its Catholic past with continental influences on theology and practice. For my purposes, the tenets of Laudianism, especially as a site of moderation begin with Thomas Cranmer, whose 
creation of the $B C P$ and its ever-important essay "Of Ceremonies" distanced the practice of the English Church from a more superstitious Rome. ${ }^{24}$ This view approaches systematization in Hooker's Ecclesiastical Polity in the 1590s ${ }^{25}$ However, most prominent expressions of Laudianism come from the churchmanship of Lancelot Andrewes and his ilk, especially as practiced, preached, and published between 16181630. ${ }^{26}$ While there has always - from Cranmer, Hooker, and Cosin - been some element of responding to puritan and Reformed critiques, the tenets of Laudianism seek to reform practice rather than eradicate altogether the influence of Calvin's more austere followers.

Though much scholarship has stemmed from Nicholas Tyacke's "anti-Calvinist" thesis, I try to avoid referring to Laudians as Arminian except in specific cases where they rail against predestination. ${ }^{27}$ Part of the avoidance of Arminian stems from the methodological focus of not relying on a single issue to determine belief - predestination was important, and James banned the preaching of it, but like the purported antiCalvinism (or the more prominent Stuart anti-puritanism), it was not the sole factor in whether one was Laudian. I am, in some ways, taking the opposite approach of Alec Ryrie: though he recognizes the insufficiency of the English Protestant binary, his inclusive vision of English religion nevertheless relegates Laudians to the margins, on the outside looking in; while I recognize that there are "moderate" and "conforming" puritans, in an attempt not to conflate puritanism with Calvinism writ large, I tend to reserve puritan for those nonconforming or anti-state church Calvinists. ${ }^{28}$ This is not to diminish the importance or widespread notions of puritan thought, but to accentuate Laudian thought and show, especially in Chapter Three, how mainstream their core ideas were. Some of the difference in interpretation stems from what we mean by "Calvinist" - 
whether it refers to a follower of Calvin's writings, the Reformed tradition stemming from Calvin's efforts, or those second- or third-generation Calvinists who, in England, take us closer to views of puritanism than Calvin himself would. ${ }^{29}$ Much of the religious conformity of the Laudians aligned with Calvinist thought, especially when setting aside the conflict between predestination and Arminian to focus on the debate over churchmanship.

III. Laudianism, Avant-Garde Conformity, and Calvinism

So what, then, makes a Laudian? One of the premises of this project is that the term in general scholarly parlance is insufficient in capturing the full range that the term can encompass. The biggest component of my argument for a broader understanding of Laudianism is that we need not see the ideology as exclusively anti-Calvinist, though scholarship often adopts an anti-Calvinist or anti-puritan frame when discussing Laudianism. The two scholars most responsible for adding nuance to the contemporary understanding of Laudianism are Peter Lake and Anthony Milton, to whom I will give ample space before adding my own clarifications. ${ }^{30}$ Milton's views are more easily summable. Throughout the Oxford History of Anglicanism he categorizes Laudianism as a mix of "high church ceremonialism, vigorous clericalism, and the doctrinal repositioning of the Church vis-à-vis Rome and Reformed Protestantism," along with a "consciously inimical" attacking of the "perceived over-emphasis on the importance of preaching" to mirror its "anti-puritan edge," which assumed that the "church's evangelical traditions and Calvinist doctrines were incompatible with a reverence for the past and the 'beauty of holiness'." Other defining features include the preference for altar, priest, and sacrifice to be used in official documents over table and minister, and a 
historical ritualism (part of the "doctrinal repositioning") derived from the Church Fathers, medieval tradition, and the Old Testament Solomonic Temple. ${ }^{31}$ It is worth noting that the divide over sermons is overstated: the Laudian critique of sermon-centered piety does not seek to eliminate the role of sermons in English devotion but diminish the practice of reducing worship to sermon-hearing, which may come at the expense of the service itself or, when done too frequently (sermon-gadding), prevent the hearer from reflecting on the preacher's words and taking action. Most scholars do not distinguish between different conceptions of the beauty of holiness. As I argue in Chapter One, Andrewes's preaching on the beauty of holiness is not identical to the characteristics of Laud's more famous campaign and is similar to Hooker's treatment in the Ecclesiastical Lawes of Politie. ${ }^{32}$ At no point does he, or any of the authors in this project, say that the reverence demanded by the beauty of holiness is incompatible with Calvinist doctrine. Many of Milton's characterizations stem from Peter Lake's groundwork. Lake's most concise explications - if brevity is possible for an author whose self-assessment admits that his writing produces "acres of Lakeian prose"- of Laudianism come from his essays on "Laudian Style" and Avant-Garde Conformity. In the former, he looks explicitly at the Laudianism of the 1630s to argue that Laudianism "did exist as a coherent, distinctive and polemically aggressive vision of the Church, the divine presence in the world and the appropriate response to that presence." Though Lake may be alone in arguing for a coherent vision of Laudianism, his arguments about participation deserve attention. In religious services, ceremonies serve as "visible sermons" to teach laity reverence, humility, and worship. In terms of grace, Lake's picture of Laudianism is notably anti-Calvinist, mirroring Tyacke's emphasis on predestination: "Laudian attitudes 
to the sacraments as the prime source of a potentially saving grace, offered first in baptism and then in the Eucharist to all members of the visible church implied a view of the theology of grace very different from the absolute predestinarianism which passed for orthodox among many educated English protestants." ${ }^{33}$ Lake coined "Avant-Garde Conformity" to provide a chronological link in the anti-puritan churchmanship between Hooker and Laud. ${ }^{34}$ He provides a useful distinction between political puritanism - those against monarchy and a king-led church - and puritan piety, to which he juxtaposed Andrewes's and Buckeridge's brand of conformity. Where Lake posits Hooker's "broadly based vision of Christian community" that joined all together in the sacraments, he likewise sees an inward-facing style of piety that was "word-centred, predestinarian, concerned with separating the godly off from the ungodly." 35 With this dichotomy regardless of its verity (I find it misleading, at best) - an inclusive view of Laudianism makes sense. ${ }^{36}$ As in Herbert's "Come ye hither all" of "The Invitation," the sacrament of the Eucharist is open to all, not just those assured of their elect status. ${ }^{37}$ Likewise, Laudian divines encourage ceremonial participation for all who attend the divine service. ${ }^{38}$

As mentioned, Lake's very frame promulgates a polemical us-verse-them attitude, which is misleading when one considers his sources. After defining a version of puritan piety, Lake uses a two-part frame to outline the tenets of Avant-Garde Conformity in terms of what Andrewes hated and what he liked, gleaned from a select choice of sermons mostly delivered between 1614 and 1618. While there is a certain argument to be made for polemics requiring an audience - and Andrewes certainly levied sarcasm against what is commonly perceived as Calvinist behaviors - it is important to remember, 
as I argue in Chapter One, that most sermons are not, inherently, polemics and to take them as in that vein or as theological treatises equivocates their original, preached context. ${ }^{39}$ For Andrewes, an irenic preacher who in Lake's own assessment was "chronically devoid both of political sense and gumption," it seems unbecoming to preach conformity in a "polemically aggressive" manner. ${ }^{40}$ Nevertheless, Lake enumerates that Andrewes hated threats to order, hierarchy, and nonconformity, in addition to the cult of the sermon and the "spiritual idolatry" that coexisted with hypocrisy. Citing largely from Andrewes's 1616 Whitsunday sermon, Lake shows Andrewes's distaste for "those merely formal marks of apparent zeal" or "outward works and observances of their own making rather than any duties required of them by God;" without the grace of the Spirit, Andrewes condemns these hypocritical acts as "an outward show of godliness, but no inward power" or "no inward holiness."41 Coincidentally, these accusations are familiar to those waged against the Andrewesian brand of ceremony, except Andrewes critiqued the love of "Christian liberty" in which the "irreligious profaneness" that sought to avoid superstition came at the expense of “outward ceremonies.” For this inner-outer dichotomy, Lake turns to Buckeridge's concerns with presumption affecting behavior inside the church: "The contemporary obsession with the inward at the expense of the outward, with faith and not with works, with the gospel not the law caused many Christians to behave as though God had made only their souls and not their bodies and offer him only spiritual and not physical or outward reverence." ${ }^{\prime 2}$ Concerns with presumption, profaneness, superstition, and inward holiness feature throughout this project. To counter the things Andrewes (and, less-so, Buckeridge) hated, Lake then celebrated those things Andrewes preached positively: 
Christ crucified, Christ rising from the tomb, repentance and good works (distinguished from merit and free will), the trio of praise, fasting, and alms (a theme that, unacknowledged by Lake, emerges especially in Andrewes's Lenten sermons and will appear in Cosin's Private Devotions), the adoration of Christ, prayer, the sacraments, and the great feasts of the church. ${ }^{43}$ From Lake's assessment, we a see a ceremonially inclined Andrewes, which was largely influential in terms of defining what would become Laudianism. Key to Andrewes's views is a Christocentric participation - both in the Eucharist, but also in other holy acts or works.

Despite a scholarly trend to pit sacramental piety against Word-centered piety, neither inherently contradicts Calvinism nor are they diametric opposites. ${ }^{44}$ As Doerksen - a proponent of Herbert-as-Calvinist - explains, Calvin "recognized the Word preached and the Sacraments duly administered as the essentials of the church (as do the English 39 Articles). ${ }^{45}$ It is a false dichotomy to separate the sacraments from Word-centered piety. ${ }^{46}$ Although the traditions surrounding the Eucharist may have evolved and, from a Protestant viewpoint, became too idolatrous under Catholicism, the basis of the practice stems from Scripture. We should not have to nuance our understanding of Protestant theology to see these as noncompeting ideas. However, this dichotomy has persisted, in part due to scholars not fully contextualizing the polemical claims of the seventeenthcentury authors. An example of this might be seen through Alec Ryrie, who dismisses the Laudian critique of sermon-centered piety ("that puritans valued preaching over prayer") as a tendentious "calumny" while later admitting a "wider Protestant horror of idleness" without connecting the two ideas. ${ }^{47}$ For Andrewes and his Avant-Garde Conformist peers, the perceived emphasis on preaching may, at worst, encourage the passivity of the 
hearer (as seen in Chapters One, Two, and Four). As Lake describes, sacraments were more efficacious for all, and sermons should aid sacrament and prayer, rather than replace them. As he says, "Prayer was, therefore, the natural accomplice of preaching. . . Thus like the sacrament prayer was a source of enabling grace." ${ }^{48}$ The fear for Andrewes was that sermon-hearing was itself the goal, not the prayer or sacramental participation it should inspire. One caveat here may be the connotation of prayer. Ryrie writes about prayer in a broad sense. Lake may be conflating "prayer" with the "public prayer" of the liturgy and service; as addressed in multiple chapters, there are several early modern individuals concerned with the practice of attending sermons only to leave before the service itself, a complaint that may date to Chrysostom. ${ }^{49}$ Concerns of liturgical adherence laid out in the $B C P$ feature prominently in this project - "what is the entire liturgy if not a ceremony?"50 This should not be surprising, as the $B C P$ is the most common object of conformity (also relevant are the church canons, 39 Articles, and Acts of Settlement or Uniformity) and provides models for prayer and sacramental observance. ${ }^{51}$ However, unlike its temporary replacement in the Directory of Public Worship, the $B C P$ is less concerned with the content or framing of the sermons themselves. ${ }^{52}$ Chapter Two, which only obliquely contributes to the sacrament-sermon debate of the period, does focus on liturgical conformity in that Cosin's Collection of Private Devotions sought to take the liturgical practices of the $B C P$ and translate them into private devotional acts.

What makes the Eucharist contentious is not necessarily the sacrament itself but how it was to be received. Spinks comments that between the Hampton Court Conference, the Articles of Perth, and the Spanish Match, King James I's rule was 
bookended by controversies over gesture and kneeling. ${ }^{53}$ Ryrie argues that kneeling was a widespread Christian practice, a "simple metonym for prayer" and uncontroversial in any context other than communion (though Chapter Three argues that the enthusiastic vigor for which private devotionals admonish kneeling in prayer suggests otherwise). $\mathrm{He}$ writes, "It was precisely because kneeling was such a universal symbol of worship that kneeling before a communion table was felt to be idolatrous. Outside that setting, kneeling to pray was an unexpected and entirely uncontroversial norm." In every chapter we will see just how the various preachers align with Ryrie's overview; most do not quibble with his assessment that kneeling is "universally accepted symbol of submission and humility ... not merely a sign of inward humiliation, but a help to it" but apply it to different degrees. ${ }^{54}$ Kneeling is a site of controversy because it reveals the distinction that some people make about the totality of using the body in worship - is it, as Lake suggests "Buckeridge claimed[,] that outward bodily reverence both expressed and helped to form or create internal spiritual reverence," or is gesture a wholly external act? In Lake's assessment, "for Andrewes it was, of course, axiomatic that such unity should take an outward physical as well as an inward spiritual form." ${ }^{55}$ While Lake says such a view is axiomatic for Andrewes, these quotations are the only two references he makes to blending inward and outward shows of piety through gesture, even though much of the 1618 sermons concern themselves with this because inward piety is required to avoid superstition. ${ }^{56}$ Like Andrewes's puritan-leaning critics, such scant reference to the inward seems to give credence to a view that the Avant-Garde Conformist position on gesture is wholly external. ${ }^{57}$ I argue against that view. The Laudian view of gesture is sacramental. Gesture is the "outward visible sign" of the "inward and invisible grace;" gesture only 
becomes superstitious or hypocritical if it is lacking grace or inward sincerity of devotion. ${ }^{58}$ Though Calvinist-branded devotion apparently focuses more on meditating and finding those inward thoughts, for Andrewes and Buckeridge, that inner devotion is requisite for holy displays of reverence.

The two greatest inhibitors to accepting a moderate Laudianism or Avant-Garde Conformity are a general skepticism or refusing to take early modern writers at their word and spreading the Civil War's puritan-royalist binary to the entire history of the Church of England, as if the Carolinian authoritarianism of Laud and Charles from around 1633-1645 is emblematic of all ceremonial conformists. ${ }^{59}$ Much of my project concerns itself with unraveling the second, so I will focus here on the first inhibitor of skepticism. This plays out in two ways: the first is failing to distinguish Laudianism from Catholicism, and the second dismisses the actual words Laudian writers produced. The first occurs most notably in Herbert criticism. As discussed in Chapter Four, many scholars of Herbert repeat what has become a truism about his religious identity almost always divided between Calvinism and Laudianism (or Anglo-Catholicism). ${ }^{60}$ In some variations this has morphed into a distinction between Catholicism and Protestantism, due to the medieval past and Catholic meditative practices evoked at the start of The Church poems inside The Temple. ${ }^{61}$ Laudianism is Protestant. ${ }^{62}$ Cosin's Private Devotions are attacked as Crypto-Catholic, but they maintain a Protestant sensibility if read as sincere. In his funeral oration, Laud maintained his Protestant identity: "I was borne and baptized in the bosome of the Church of England, as it stands yet established by Law, in that profession I have ever since lived, and in that profession of the Protestant Religion here established I come now to die . . . therefore I desire it may be remembred: O have 
alwayes lived in the Protestant Religion established in England." ${ }^{63}$ The difference in interpretation stems from degree. In this case, it has to do with views of how the Church of England coexists with the universal Christian church. Laudians saw the Church of England as reformed from the erred, Catholic tradition; puritans and left-leaning Calvinists saw them as reformed against it and began their ecclesiastical history with late medieval reformers, like Tyndale and Wycliff, in favor of abandoning church tradition altogether with new interpretations of Scripture. ${ }^{64}$ For those not concerned with discerning a difference between Roman Catholic tradition and the primitive church, there still exists a skepticism in taking statements of faith and belief at face value, which may stem from uncritically accepting or internalizing the contemporary critiques of superstition and idolatry. This leads to scholars dismissing moments where Laudian writers express a concern with the inner state of the soul. ${ }^{65}$

When we read the early modern Laudians as being sincere in their writings (i.e., taking them at face-value and not as examples of rhetorical chicanery) the case for a Protestant Laudianism does, or should, not seem innovative. In addition to basing their practices on the Ancient Church, Laudianism has a large, if muted, theological debt to continental Lutheranism. Doubtlessly, some of the claims for innovation stem from contemporary voices that eschew continental contexts. In a 1639 letter, Scottish Puritan Robert Baillie decried the "English method of study," in which English divinity students allegedly read exclusively from the Fathers and English theologians while ignoring the writings of continental theologians. ${ }^{66}$ In attempting to read a direct influence of Calvin on Herbert, Doerksen reiterates the spirit of Baillie's claim that Laudians were not that concerned with continental influences (which might help explain James's refusal to send 
Avant-Garde Conformists to the Synod of Dort) ${ }^{67}$ English puritans, on the other hand, owe a strong allegiance to second-generation English Calvinists, many of whom may have been more extreme than Calvin himself. One of the seminal readings of Herbert-asCalvinist is Strier's Love Known, which posits the influence of Luther's justification-byfaith doctrine on Calvin and Herbert while admitting the distinction between Anglicans and puritans is "crudely and unhistorically drawn." ${ }^{68}$ Luther's influence on English Protestantism is not wholly Calvinist in the sense literary scholars take it to be. Where Strier sees a connection between Luther and Calvin, Veith points out that scholars are quick to overlook Lutheran sacramentalism (more prominent in the lower continent) and ceremonialism. Similarly, Milton admits "many Lutheran churches at this time retained a high ceremonialism which would have made Lancelot Andrewes' mouth water." ${ }^{69}$ More recently, Peter McCullough has identified Luther and Chemnitz as the two largest influences on Andrewes's theology, even if the influence was never explicitly acknowledged in his writings. ${ }^{70}$ If Andrewes is the spiritual godfather to Laudianism, then his channeling of Lutheran theology imbues Laudianism with continental Protestantism and influence. ${ }^{71}$ All in all, Laudians may have had an insular focus on empowering the structure of the English church, but to suggest that they are either sui generis or crypto-Catholic is to dismiss the full depth of their views.

Drawn in part from a Lutheran theology of the cross, the last element of Laudianism that I will highlight here is their emphasis on action - on doing. Although part of this stems from a Hookerian sacramentalism - "sacraments are actions religious and mystical" - the stirring to devout action extends beyond sacramental and liturgical participation. ${ }^{72}$ While Ryrie points out that idleness is the bugbear of all Protestants, 
Laudianism and ceremonialism place a particular emphasis on doing, especially with all parts of the body, from kneeling to directing the gaze ${ }^{73}$ Peter McCullough has shown Andrewes's Elizabethan Lenten sermons to reflect a certain Lutheran Christocentric, theology of the cross, where the preacher exhorts the auditory to formulate mental and verbal crosses, as gazing explicitly on the crucifix is too reminiscent of Catholicism. ${ }^{74}$ Looking upon Christ, the cross, and other images plays out in several chapters, including Buckeridge's use of the vide o patior meditational tradition and Herbert's Holy Week sequence poems. One biblical crux for this program of doing is James 1:22, a text that ends Thomas Tymme's 1618 Chariot of Devotion (discussed in Chapter Three) and serves as sermon-text for Andrewes in 1607. The verse reads "And be yee doers of the Word, and not hearers onely, deceiving your owne selves." ${ }^{.75}$ Naturally, Andrewes uses this verse as an attack against sermon-centered piety but does not dismiss the value of sermons ${ }^{76} \mathrm{He}$ criticizes those who do nothing but listen to sermons, a distinction often glossed over in scholarship. Compare the opening of the sermon, which relays a danger of restricting the Word only to sermons, to its first heading: "An advise or Caution of S. James, to those that receive the word ingrafted. And that so necessary an advise, as without which, all our receiving the word, or hearing Sermons, is nothing els (saith he) but a very coosening or deceiving our selves." The first point of the sermon, however, places hearing in tandem with doing: "We beginne with this, that Saint James, in saying, Be not hearers onely, this he saith: Be hearers, but not onely hearers; be ye doers too: but, be hearers still." ${ }^{, 77}$ Sermons are important, but the real importance is doing or enacting the Word, being driven to action. This message was so important that, though Andrewes intended to expound the latter part of the verse, "deceiving your owne 
selves," he ran out of time declaiming on the first part. How does one be a "doer" of the Word? Unsurprisingly for Andrewes, it begins with the Sacrament: "Which very Sacrament of godlinesse is there said to be the manifesting of the word in the flesh: which it selfe is lively expressed by us, when we are doers of the Word." ${ }^{, 78}$ Here should be an example of a rebuttal of the Word-based, Sacrament-based dichotomy of religion. The importance of the sacraments - their salvific essentiality - stems from the scriptural injunctions to participate in them and partake. Sacraments are not to replace sermons but stand beside them in a full demonstration of Christian service (through the divine service). Ceremonial gestures, which are non-essential, likewise bolster the service in reflecting inward piety. Neglecting any one part does a disservice to both Christian and God, which is why Laudians stress the inward as a part of the external. When joined together, worship resembles earlier ceremonial practices that lack excess superstition, despite what critics might argue to the contrary.

\section{Chapter Outline and Interventions}

Each chapter concerns itself with a different genre. I use this organization for two purposes. First is that it allows a broader depth of sources for understanding Laudianism. Traditionally, church historians have focused on sermons, laws, and theological prose tracts for their basis of Laudianism, which tends to elevate the political and polemical elements of the source material. To these, I add private devotionals and poetry. With scholars taking their cue from Ian Green, private devotionals have received little attention as vessels for Laudianism because of the perception that the genre's goal is teaching the basic tenets of Christian beliefs. The thought is that the ecclesiastical debates (over 
"indifferent" matters) are too complex to be given space, though this becomes less true closer to the Interregnum and after the Restoration. As such, private devotionals are an underexplored genre for Laudian concerns. Scholars have often mined poetry for religious beliefs, and, in that regard, this dissertation is no different. Second, dividing by genre allows more focus to be given to the literary elements of each genre, where I can consider each genre on its own terms, rather restricting the interpretation purely for religious or political purposes. In addition to dividing chapters by genre, I also proceed in a mostly chronological order, beginning with court sermons published in 1618 and ending with The Temple, published in 1633. The exception to this is Chapter Three, which surveys devotional works published between 1612 and 1635.

To begin with the court sermons of 1618 is no accident, as it is the year - despite the Synod of Dort - that the English Court begins its turn towards Laudianism. The publication of Lancelot Andrewes's 1617 Gunpowder Plot Anniversary Sermon and John Buckeridge's 1618 Passion Sunday kicked off an uptick in publications over gesture and kneeling - inspired, no doubt, by a desire to support King James I's efforts in Scotland with the Articles of Perth. Though I also discuss Andrewes's 1618 Easter Sermon, these first two sermons feature prominently in almost every discussion of proto-Laudianism though, with the exception of Peter McCullough, few explicitly draw attention to the chronological proximity of the sermons, and even then, that acknowledgement appears mostly in footnotes. Most significantly perhaps, these two works form the basis of Peter Lake's discussion of Avant-Garde Conformity, though Bryan D. Spinks and Lori Anne Ferrell cull from them extensively in their respective discussions of "Patristic Reformed Churchmanship" and kneeling. ${ }^{79}$ As such, these works mark the apparent Jacobean turn 
towards Laudianism, though Andrewes's conception of the "beauty of holiness" is far less severe and external than the 1630s Laudian conception.

In terms of genre, the recent renaissance of sermon studies over the last thirty years has begun to reclaim sermons from being read as historical, wholly polemical or legal documents. Drawing on Mary Morrissey's distinction between rhetorical and political reading (or the more recent delineations of treating sermons as rhetorical performances as opposed to written record), I situate these three sermons in two contexts: the exhortatory performances of preachers persuading their auditors towards holy behavior and the underlying political subtext that makes these sermons royal propaganda in support of the ecclesiastical state structure. By drawing attention to these three sermons, all delivered in the span of five months at Whitehall Chapel, I read closely a small subset of sermons to draw attention to their immediate context, as opposed to those studies that focus strictly on location or occasion. ${ }^{80}$ Though I am using these sermons as the introduction to Laudian ideas, I simultaneously acknowledge that these works do not represent the whole corpus of Andrewes and Buckeridge, but reflect their views as of 1617 and $1618 .{ }^{81}$ While these sermons might exemplify some have taken to be radical notions of Avant-Garde Conformity of proto-Laudianism, I maintain that their worship exhortations are inherently moderate in nature (a view perhaps exemplified through Buckeridge's hedging, in the conclusion to the attached polemical tract, from his sermonic statement that kneeling is not adiaphora).

From sermons, I progress to devotion manuals. It is an odd endeavor to calculate English devotions as a broad genre, though some have tried. Perhaps more so than any other genre explored here, devotional prose offers the most fluidity in English Protestant 
thought because many texts can have a devotional angle though they might differ in form or intent. For my purpose, a devotional is a text that centers on some how-to element: how to worship, how to pray, how to practice piety, and so forth. Thus, they perhaps best show and challenge my thesis that Laudianism was broad and inclusive: as we will see with Herbert, much of the theological underpinnings I identify have been claimed by Calvinist and Laudian scholars alike. As stated above, I am taking the opposite approach of Alec Ryrie, whose well-read and well-sourced Being Protestant in Reformation Britain aims to eschew the Anglican-puritan binary but still keeps Laudianism outside the mainstream of Protestant thought. ${ }^{82}$ Though I admit Laudianism has some antipredestination moments, I read Laudianism as being in-line with mainstream England Protestantism (and, in full disclaimer, I probably do to puritanism what he does with Laudianism - not because I think they belong on the fringe but because scholarship has explored puritanism more intensely than Laudianism).

It is important to note that few scholars have looked broadly at the devotional genre; most literary scholars tend to identify smaller subsets and focus on that theme (often applied to a certain type of devotional or Eucharistic poetics, where the devotions are subsidiary to the "literature") rather than treat them as a distinct genre. This may stem from the overabundance of religious prose texts published in the seventeenth century. The Library of Anglo-Catholic Theology (a subset of the Oxford Movement and the Tractarians) did much to reclaim seventeenth-century divines as exemplifying the Anglican via media, but this work has given much work an Anglican bias, as seen in the works of C.J. Stranks. Helen White - perhaps the seminal devotions scholar and the first twentieth-century scholar to treat these works in-depth - painted broad strokes of English 
devotional practice, but her scholarship is perhaps limited by the prominent Anglicanpuritan binary. Ian Green's treatment is perhaps the most systemic and magisterial. Much of my argument is framed against Green's warning that English devotionals are not confessional battlegrounds because, in addition to being more complex than the fundamentals of religion, such debates were more were beyond the scope of the intended household, family, or individual audiences. ${ }^{83}$ I show that this is not the case, especially when Laudianism is taken be moderate and inclusive rather focused on than rigid enforcement.

The difference in degree - between moderation and a tight construction - is why I have two chapters on devotions. More properly, Chapter Two examines the polemical aspects of publishing devotions, whereas Chapter Three ignores the polemical potential of the genre to examine its calls to pious action. Despite the focus in Chapter Two on John Cosin's 1627 Collection of Private Devotions, much space is given to how William Prynne and Henry Burton read the devotions as polemic and responded in kind. Following Davies's cue on Prynne being responsible for our binary understanding of Laudianism, I give space to the deliberate puritan misreading to show how Cosin's prayerbook - even if it was written for English ladies-at-court to compete with their Catholic counterparts - became more controversial due to their rhetorical cries of popery and Arminianism rather than what Cosin actually wrote. ${ }^{84}$ Whether Cosin's refusal to engage or defend his work publicly is an admission of guilt or he sincerely thought the claims ridiculous and thus not worth considering is up to debate. ${ }^{85}$ The second half of the chapter turns to look at Daniel Featley's 1626-27 Ancilla Pietatis. I paint Featley's work in a similar light to Cosin's: it contains set form of devotions, defends the institution of 
the church, yet, despite the second edition including some defenses of feast days and fasting, it escaped the puritan scorn that was leavened upon Cosin (possibly because of Featley's support in licensing puritan works or the lack of evidence that Featley abused his non-conforming parishioners as Cosin did in Durham). I offer it as a juxtaposition for how the genre can function, and what the absence of polemical detractors can do for a work's legacy.

I focus on Cosin's polemical legacy because it typifies the Laudian-puritan divide. In Chapter Three, I shift to a broader survey of devotional works of varying popularities. I begin with Thomas Tymme's A Chariot of Devotion, a single-edition 1618 publication written by a preacher of a small parish whose religious inclinations strongly mirror the sermons preached at Whitehall in the same year, which I take as evidence of the "Laudian concerns" at court to be far broader in scope than being relegated to the upper echelon of James's court. ${ }^{86}$ From there, I read Lewis Bayly's immensely popular and encyclopedic Practise of Piety (c. 1612) to show the conformist elements in an encyclopedic manual of how to be pious. I then move to the first publications of Charles Herle and Henry Tozer, both attached to Exeter College, who wrote two very different works with one being a single edition and the other becoming a bestseller. These texts show the range of devotional thought and expand beyond the London court. While many of these works in this chapter contain a dedicatory epistle to English elites, the devotional concerns are nevertheless wide-reaching and demonstrate Laudian sympathies to all English Protestants.

Most of the authors in this dissertation were preachers - such was the state of having a university education in the seventeenth century - and Chapter Four adds another 
genre for consideration, poetry. Lyric poetry often expresses private desires. Because much of Laudianism is public facing in nature, I use George Herbert's poetry to see how these elements take shape in what is considered to be some of the most personal expressions of piety and devotion. My argument about Herbert is two-fold. First, my identification of him as Laudian does not contradict those scholars who wish to claim a “precise doctrinal allegiance" of Herbert's theology. A Laudian Herbert does not preclude a Calvinist Herbert. Rather, an inclusive Laudianism helps explain his moderate views that draw on a range of theological influences, from Catholic to puritan and everything in in between, without contradiction. ${ }^{87}$ Part of this stems from the second argument, which is the identification of Laudian sequences. This draws on previous work that identifies poetic sequences in The Temple to emphasize the Eucharistic undercurrent, which, with baptism, promotes a strong sense of sacramentalism tied to the church year. ${ }^{88}$ Throughout the chapter, I offer a reading of multiple poems in relation to their sequence, their sacramental importance, other Laudian components. At no point does my Laudian reading preclude Herbert's belief in assurance, predestination, or other exemplary Calvinist themes. This reading of Herbert diminishes the tendency to stake competing views of Herbert against each other. Mindful of the appearance of contradictory "habits of mind," I argue that Herbert's Protestantism - his use of Laudianism - can be explained when the Calvinist-Laudian binary is dropped. ${ }^{89}$

Unlike other poets, Herbert may be the most famous seventeenth-century poet whose competing religious views are less "explained" by chronology or political opportunism, such as Donne's later Arminianism or the dichotomy between the "young" and "old" Milton. ${ }^{90}$ Moreover, his Andrewesian avoidance of controversy (while 
nevertheless engaging in it) likens him to the quasi-irenic Laudianism that features so prominently throughout this dissertation. At no point do I seek to rank the genres. Instead, I highlight how the diversity of formal modes of religious expression speak to importance of religion in daily life of the English Christian. Though religion becomes explicitly and deathly political towards the middle of the century, what emerges in the first half of the seventeenth century is a wide promotion of ceremonial worship that gives the worshipper a formal apparatus to demonstrate their devotion and explore their piety in private and communal modes. These concerns variously emerge among the different genres and become more dichotomous and in the years of Laud and Charles, an age of print that constantly vilified political and religious opponents. These strident tones, however, are lacking in the early promotion of Laudianism.

It is because of this evolution that the epigraphs to this introduction are relevant. Simply put, my intervention is to clarify early forms and definitions of Laudianism. While that is only one part of the story of Laudianism, this dissertation establishes the foundations that set the stage for the later acts when Laudianism sparks militant reactions. The use of Laudian as dismissive epithet, as Judith Maltby suggests, often obscures the religious landscape of seventeenth-century England because it provides a strawman for scholars to emphasize the distinctly Calvinist elements of English Protestantism against a distortion of the ceremonial. In this vein of distortion, Tyacke's comments about Laudian not being easy to define or apply have a certain aura of irony - after all, it is Tyacke who may be most responsible for the idea that Laudianism was the project of a "minority group" of preachers at James's court. ${ }^{91}$ His reference to those that deny Laud was a Laudian alludes to Julian Davies's then-forthcoming thesis that sought to disabuse Laud 
from the extremes of Laudianism. Davies, however, simply shifted the blame. Instead of Laud, Andrewes was at fault for instituting the models on which Laudianism takes its form (never mind that Andrewes only admonished, rather than enforced religious practice), and Wren and Charles were to blame for the rigid enforcement of the "beauty of holiness." Tyacke sought his own easy alternative. Instead of exploring the nuances of Laudianism, he restricted his work to the issue of predestination, where Arminian, itself a term of abuse used by the puritans, was a catch-all term that itself was not intrinsically ceremonial. While some of the writers in this project lived in and survived the Civil Wars, the works examined here were products of a less factional society. Few exclusionary or punitive politics are at play in the early form of Laudianism. Instead, these religious divines sought to continue the reformation of the Church, both the institution and her members, in the vein of Cranmer and St. Paul - with all things being done for decency, order, and edification.

\footnotetext{
${ }^{1}$ Respectively, Judith Maltby, Prayer Book and People in Elizabethan and Early Stuart England (Cambridge: CUP, 1998), 162 and Nicholas Tyacke, Anti-Calvinists: The Rise of English Arminianism c. 1590-1640, (Oxford: Clarendon Press, 1991 reprint), xi. Tyacke refers specifically to Julian Davies (cited below), though Kevin Sharpe shares similar beliefs. ${ }^{2}$ These distortions are discussed more below, especially in Chapter Two. For an example of scholarly skepticism see Judy Z. Kronenfeld, "Probing the Relationship between Poetry and Ideology: Herbert's 'The Windows," John Donne Journal 2.1 (1983): 61: "It is thus not difficult to find in Herbert, and in Donne and in Laud as well, some evidence for an emphasis of some kind on the inevitable combination of internal worth or meaning and external show, because that is the only way anyone ever talks about 'externals"' (her emphasis).

${ }^{3}$ Anthony Milton, ed. Oxford History of Anglicanism, Volume 1: Reformation and Identity, c.1520-1662 (Oxford: OUP, 2017), xvii and 1. The first quotation is by series editor Rowan Strong.

${ }^{4}$ Tyacke's Anti-Calvinists argued that it was the Arminians, a minority position at court, that caused the political and ecclesiastical damage to the church rather than the Puritans. Peter Lake's work, such as Anglicans and Puritans? Presbyterian and English Conformist Thought from Whitgift to Hooker (London: Unwin Hyman, 1988), has shown the diversity of viewpoints along conformist views. Anthony Milton has argued that the effect of Revisionism was to change the Anglican/puritan binary to Arminian/Calvinist. "Arminians, Laudians, Anglicans, and Revisionists: Back to Which Drawing Board?” Huntington Library Quarterly 78.4 (2015): 723 742.
} 
${ }^{5}$ Thus, at the start of the twentieth century, works like Edward Dowden's Puritan and Anglican: Studies in Literature (London: Kegan Paul, Trench, Trubner, 1900) rely upon an Anglo-Catholic stereotype of Anglicanism. T.S. Eliot, who converted to Anglicanism and identified himself as Anglo-Catholic in religion, may be the literary critic who established Lancelot Andrewes as a "Caroline divine."

${ }^{6}$ The works of Patrick Collinson and Peter Lake have been at the forefront of this move to broaden understandings of puritanism and early English (often Elizabethan) religion.

${ }^{7}$ See the assessment of Patrick J. McGrath, "Reconsidering Laud: Puritans and Anglican Asceticism" Prose Studies 34.1 (April 2012): 32, "Most fundamentally, have we fully understood what constitutes Laudianism? This studies argues that we have not."

${ }^{8}$ While there are others, the works of Christopher Hodgkins and Daniel Doerksen perhaps most demonstrate the restricted sense of Laudianism. See for instance Daniel Doerksen, Conforming to the Word: Herbert, Donne, and the English Church before Laud (Lewisburg: Bucknell UP, 1997), 69, where there is little reference to Laudian conformity that does not boil down to the altar rail, east-end placement of the altar, and kneeling. See 67 for his surprise that Andrewes would place the pulpit higher than the reading desk: the "anti-sermon" preaching of Laudians was not against sermons as a whole but the emphasis of them over the liturgical service. The view that Laudianism is "new conformity" (whereas Calvinists were a part of the "old conformity") completely obfuscates the role of tradition and the primitive church in Laudian ideas. Cf. Calvin Lane, The Laudians and the Elizabethan Church: History, Conformity, and Religious Identity in Post-Reformation England (London: Pickering \& Chatto Publishers, 2013), who argues the Laudian lineage stems largely from Elizabethan practice, which defines Cosin's methodology behind his prayerbook.

${ }^{9}$ See for instance Alec Ryrie's excellent Being Protestant in Reformation England (Oxford, OUP: 2013), which seeks to avoid religious labels for English Protestants for everyone but the Laudians, or Doerksen, Conforming to the Word, 22, for a charted conceptualization of the Jacobean via media centered around broad views of conformity that most Laudians would actually agree with, rather than be separated from (reprinted in Doerksen and Hodgkins, eds. Centered on the Word: Literature, Scripture, and Tudor-Stuart Middle Way [Newark: University of Delaware Press, 2004]). This is discussed below; see also note 44 below.

${ }^{10}$ See for instance, Doerksen, Conforming to the Word, 69.

${ }^{11}$ Julian Davies, The Caroline Captivity of the Church: Charles I and the Remoulding of Anglicanism 1625-1641 (Oxford: OUP, 1992), argues that much of our view of Laudianism stems from Prynne and rigid enforcement stems from Charles I, rather than Laud (which is why he prefers Carolinian to Laudian). See in particular 46-7, where he explores how Prynne misread Laud's works in 1645's Canterburies Doome, which I apply to Prynne's reading of Cosin in Chapter Two. Also, 22: "For the king, as for Laud, there could be no inner piety without its visible manifestation. . Many Puritans, however, suspected that this external worship of the heart ... resolved itself into a concern for passing, cosmetic appearances."

12 The dates are of their times as bishops. Buckeridge was Laud's Oxford tutor. Together, Laud and Buckeridge published the posthumous edition of Andrewes's sermons in XCVI Sermons (London, 1629).

${ }^{13}$ The "Calvinist Consensus" stems from Tyacke's work, which alleges at King James I's accession in 1603, he inherited a court that was predominantly Calvinist. Against this, Andrewes's churchmanship was viewed as an outlier despite his popularity as a preacher. The criticism against Tyacke's thesis is that it restricts Calvinism to views of predestination.

${ }^{14}$ Of course, the debate over (whose) tradition is one of the cornerstones of religious polemic in this period. As elaborated below, the Laudians believed in a church tradition that included the better parts of Rome's, whereas the Puritan-leaning side of the Reformed tradition rejected all things Roman. Richard Hooker sums the position nicely: "we had rather follow the perfections of them whom we like not, than in defects resemble them whom we love." The Works of that 
Learned and Judicious Divine Mr. Richard Hooker with an Account of His Life and Death by Isaac Walton, vol. 2. Ed. John Keble (Oxford: Clarendon Press, 1888, $7^{\text {th }}$ edition): Book V, Ch. xxviii, 127. Subsequent references will be abbreviated Hooker, Lawes, V.[chapter].[section].[page].

${ }^{15}$ Which is not to say that Laud had no power before 1633. In 1626 he succeeded Andrewes as Dean of the Chapel Royal, and in 1628 he was translated to Bishop of London, where he began a rigid control of the press, addressed in Chapter Two.

${ }^{16}$ Milton, History of Anglicanism, 26. I generally stand upon the conclusions he makes in his introduction, 1-27, esp. 1-10 about the "schizophrenic" nature of reformation religious identity. ${ }^{17}$ The OED first cites Laudian in 1691 and Laudianism in 1872. "Laudian, adj. and n.". OED Online. June 2020. Oxford University Press (accessed July 21, 2020). In the previous sentence I used "pre-Restoration" because most historians agree that the Church of England should not be called Anglican until the Restoration. The notion of Anglicanism was born in the nineteenth century. With high church and Anglo-Catholic theologians typologizing the works early seventeenth-century divines as being the pioneers of Anglican thought.

${ }^{18}$ Essentially, the churchmanship of Avant-Garde Conformity becomes that of Bishop Neile's "Durham House Group," which in turn becomes Laudianism. Peter Lake, "Lancelot Andrewes, John Buckeridge, and the Avant-Garde Conformity at the court of James I" in The Mental World of the Jacobean Court, ed. Linda Levy Peck, (Cambridge: Cambridge University Press, 1991): 113-133. Lake's chronology is primarily 1614-1620. The Durham House Group (of which John Cosin was a prominent, if junior, member) forms in the late 1620s. See also Peter McCullough, “"Avant-Garde Conformity' in the 1590s" in Oxford History of Anglicanism, ed. Milton, 380-394. McCullough, pairing Andrewes with Hooker, revises Lake's chronology to show the origins of Avant-Garde Conformity in the 1590s.

${ }^{19}$ The works of John Buckeridge and Lancelot Andrewes stand at the core of Lake's conceptualization. As Peter McCullough points out, Andrewes's XCVI Sermons was essentially a Laudian manifesto, due in large part to the joint editorship of Buckeridge and Laud. "Making Dead Men Speak: Laudianism, Print, and the Works of Lancelot Andrewes, 1626-1642." The Historical Journal 41, no. 2 (June 1, 1998): 401-24.

${ }^{20}$ Anthony Milton, Catholic and Reformed: The Roman and Protestant Churches in English Protestant Thought, 1600-1640 (Cambridge: CUP, 1995), 529, concludes that Laudians took the Church of England from a "more stable Protestant identity" to an unstable one. He also posits their return to the first reformation (i.e. 1530s-50s Tudor England) was read by the Calvinists as returning to popery.

${ }^{21}$ As seen in Chapter Four, George Herbert was among the first to suggest the British Church was the via media. While scholars have more recently admitted that much of the seventeenth-century Anglican via media is a myth of the Oxford Movement, the legacy is enduring. See P.G.

Stanwood, Sempiternal Season: Studies in Seventeenth-Century Devotional Writing (New York: Peter Lang, 1992), 98-9, which posits Cosin as a via media churchman while also admitting that, 116n6, the via media an invention of the Tractarians. Milton, Catholic and Reformed, 528, which suggests that the via media was first espoused by the Laudians. See MacCulloch's rebuttal in "Richard Hooker's Reputation," The English Historical Review 117.473 (2002): 773-812.See also Catherine Gimelli Martin, "Experimental Predestination in Donne's Holy Sonnets: Self-Ministry and the Early Seventeenth-Century 'Via Media,"' Studies in Philology 110. 2 (2013): 350-81, Doerksen, Conforming to the Word, 21-24 which argues for a Calvinist oriented via media, or Milton and Lake's chapters (18 and 19, respectively) in the Oxford History of Anglicanism.

${ }^{22}$ Bryan Spinks, The Rise and Fall of the Incomparable Liturgy: The Book of Common Prayer, 1559-1906 (London: SPCK, 2017), 37.

${ }^{23}$ This divide over tradition will be discussed throughout, but see Achsah Guibbory, "Devotional Poetry and the Temple of God." George Herbert Journal 37.1 (2013):101-02, where Laud had in mind the Jewish temple rather than the Mass and where Hooker and conformists saw continuity 
to an Old Testament lineage, such ceremonial adherence was "a sign that it had become a false Church." See also her Ceremony and Community from Herbert to Milton: Literature, Religion, and Cultural Conflict in Seventeenth-century England (Cambridge: CUP, 1998), 28-41 for an overview of the conflict between Laudian historical continuity and puritan discontinuity.

${ }^{24}$ Cranmer relies on Scripture and patristic tradition; echoes of his essay can be seen in the sermons of Andrewes and Buckeridge, the 1604 BCP Revision, and Hooker. Because of the significance of paratextual information and the Jacobean tenor of the 1604 revision, my citations from the $B C P$ come from the 1604 edition, except where noted. Cranmer's essay has appeared in most, if not all, editions of the BCP. Cranmer wrote, Book of Common-Prayer (London: 1604), sig. a8v: "Of such Ceremonies as be used in the Church, and have had their beginning by the institution of man: some at the first were of godly intent and purpose devised, and yet at length turned to vanitie and superstition: ... And although the keeping or omitting of a Ceremonie, in it selfe considered, is but a small thing: yet the wilfull and contemptuous transgression and breaking of a common order and discipline, is no small offence before God. Let all things bee done among you, sayth S. Paul, in a seemely and due order. The appointment of the which order, pertaineth not to private men: therefore no man ought to take in hand, nor presume to appoint or alter any publike or common order in Christs Church, except he be lawfully called and authorized thereunto." I silently modernize $i / j$ and $u / v / w$ in quotations of early modern texts, but I maintain original punctuation, most spellings, and italics.

${ }^{25}$ The influence of Hooker on Laudianism cannot be overstated; while he may not have been frequently cited in the seventeenth century, much of his religious thought is reflected in the practices laid out in this dissertation. As an echo of Cranmer, see Hooker, Lawes, V.III.i.4.25-26: "For in the Church of God sometimes it cometh to pass as in over battle grounds, the fertile disposition whereof is good; yet because it exceedeth due proportion, it bringeth forth abundantly, through too much rankness, things less profitable; whereby that which principally it should yield, being either prevented in place, or defrauded of nourishment, faileth. This (if so large a discourse were necessary) might be exemplified even by heaps of rites and customs now superstitious in the greatest part of the Christian world, which in their first original beginnings, when the strength of virtuous, devout, or charitable affection bloomed them, no man could justly have condemned as evil."

${ }^{26}$ See again Milton, Oxford History, 3-8, who offers multiple historiographies and lineages of "Anglicanism." Andrewes was named as the "Gamaliel" of the Durham House Group, which centered around Bishop Neile. Davies, for all his attempts to salvage Laud's reputation tends to repositions the "blame" for Laudian policies - enforced through Charles "Carolinism" - onto Andrewes, as he "originated" the practices, though most of Andrewes's practices were private, only attached to James's chapel at the monarch's request (he also suggests it was Wren behind some of the rigid enforcement). Carolinian Captivity 302: "Without the backing of Charles I Laudianism would have remained as it was under Andrewes: a movement enriching the sacramental life of the Church, while advancing healthy, if socially disturbing, criticism of the Erastian Reformation, combined with an unfortunate reluctance to preach from the pulpit, if not from the table."

${ }^{27}$ Tyacke's thesis was important for revisionist historiography and shifted the "blame" of the Civil War from radical puritanism to radical Laudianism. As discussed in Chapter Two, Arminianism is a contemporary term of abuse used by Prynne and Burton to criticize those licensed texts that diminish the importance of predestination.

${ }^{28}$ Ryrie, Being Protestant, 6. Doerksen, Conforming to the Word, 20 discusses conforming puritans.

${ }^{29}$ See below for examples, but Calvin's writings reveal a more moderate view of ceremony than English Calvinists - or scholars - often permit. Thus, there is a certain irony of scholars like Hodgkins or Doerksen quoting Calvin himself to show Herbert's Calvinism, when the English Calvinism of the 1620s and 1630s draws upon the works of second-generation Calvinists like 
Theodore Beza or George Perkins. See Robert Whalen, "George Herbert's Sacramental Puritanism" Renaissance Quarterly 51.4 (2001): 1281 or Gene E. Veith, Reformation Spirituality: The Religion of George Herbert, (Eugene: Wipf \& Stock: 2013 [reprint of Associated University Presses: 1985]), 28.

${ }^{30}$ This is not to say there has not been other influential scholarship. The works of Hugh TrevorRoper and Kenneth Fincham deserve mention as well. In particular, the preface to Trevor-Roper's Catholics, Anglicans, and Puritans: Seventeenth Century Essays (London: Martin Secker \& Warburg: 1987): xii draws attention to the stereotypes of Laudians as reactionary, puritans as progressive and identifies Arminian, Calvinist, and puritan as "imprecise terms, often terms of abuse." He argues, (pace Tyacke?) "It is only if we dissolve the imaginary spectrum stretching from Right to Left that the ideas which have been artificially fitted into it recover their individuality and can be studied in their true context." Fincham, Prelate as Pastor: The Episcopate of James I (Oxford: Clarendon Press, 1990), 232-38 explores notions of "Arminian piety" that align with my description of Laudianism - even citing some of the key quotations in Chapter One - but still ends with the view that the bishops "articulated their hostility to nonconformity." He later, 247, calls Arminianism and Laudianism "historiographical cousins." ${ }^{31}$ Oxford History of Anglicanism, 9, 67, and 74; summary from 67-74. Quotations are excerpted from his introduction and chapter on "Unsettled Reformations, 1603-1662." He also, 67-8, notes that it was James himself (rather than Andrewes) who commanded the Royal Chapel at Holyrood to be ornately decorated. Milton's less recent Catholic and Reformed treats the religio-political history of the church in more detail.

${ }^{32}$ Hooker, Lawes, V.XV-XVI, discusses the beauty of holiness, which argues for promoting the sumptuousness of churches, but not at the expense of Christian charity. V.XV.3.52-55: "Touching God himself, hath he any where revealed that it is his delight to dwell beggarly? ... Whereby we see how most Christian minds stood then affected, we see how joyful they were to behold the sumptuous stateliness of houses built unto God's glory." V.XVI.1-2.57-8: "Whereby also it doth come to pass, that the service of God hath not then itself such perfection of grace and comeliness, as when the dignity of place which it wisheth for doth concur. . As therefore we every where exhort all men to worship God, even so for performance of this service by the people of God assembled, we think not any place so good as the church, neither any exhortation so fit as that of David, 'O worship the Lord in the beauty of holiness."'

${ }^{33}$ Peter Lake, "The Laudian Style: Order, Uniformity and the Pursuit of the Beauty of Holiness in the 1630s" in The Early Stuart Church, 1603-1642, edited by Kenneth Fincham, 161-185, (London: Palgrave, 1993), here respectively, 162, 166, and 174. "[A]cres of Lakeian prose" comes from The Anti-Christ's Lewd Hat: Protestants, Papists and Players in Post-Reformation England, (Yale University Press: 2002), xi, co-authored by Michael Questier.

${ }^{34}$ See the note above on Peter McCullough's revision to this thesis in the 1590s to give Hooker more prominence. MacCulloch, "Richard Hooker's Reputation," 785, offers an assessment. Speaking of Buckeridge publishing a posthumous work of Hooker, he says, "he was an older and more senior man than Laud, it makes little sense to call him and those like him Laudians. The term 'High Church' is likewise too blunt an instrument for Buckeridge's new mood of sacramentalism, clericalism and distaste for the style of the earlier English Reformation: the most accurate recent description, used by Peter Lake and Anthony Milton, is 'avant-garde conformist'. That distinguishes Buckeridge and his fellows from two generations of conformists like Whitgift and Bancroft, who had not so decisively parted with the Reformed mainstream of the rest of Europe."

${ }^{35}$ Lake, "Lancelot Andrewes," 113-4.

${ }^{36}$ See Maltby, 46, who argues both conformists and puritans took the sacrament seriously, and 68, where she cites Donne's 1625 Easter sermon on joining the sermon and sacrament, to which she comments: "Donne too failed to see an antithesis between altar and pulpit. It may be that the 
antithesis exists more in the mind of the modern ecclesiastical historian than it did in the mind of the early modern parishioner or even divine."

${ }^{37}$ As in Veith, Reformation Spirituality, 23-41, where he argues assurance of election was not a concern of practicing Calvinists.

${ }^{38}$ Compare Hooker Lawes V.XIX.5.69: for the English, "public service is not voluntary." See also David Lyle Jeffrey, In the Beauty of Holiness: Art and the Bible in Western Culture, (Grand Rapids, MI: William B. Eerdmans Publishing Company, 2017), 59-60, who in the context of describing the sanctuary as being emblematic of the Eucharist and Christian eschatology writes, "The holiness of any person, place, or action engaged in authentic Christian life and worship is on this view effected by participation partaking of the immutably holy" (his emphasis; this plays out with my discussion of participation below and has resonances in Chapter One).

${ }^{39}$ Exceptions can be made. But even Peter Smart's 1628 sermon against Cosin and ceremonies maintains a veneer of expounding on Scripture, using Psalm 31:6 (printed as 31.7 - "I hate them that hold of superstitious vanities") as sermon-text. A Sermon Preached in the Cathedral Church of Durham, July $7^{\mathrm{t}}$ 1628. London(?): 1640.

40 "Avant-garde Conformity," 132. See "polemically aggressive" above in "Laudian Style" (which in context was about divines in the 1630s rather than Andrewes). See also the notes in Chapter One about Andrewes's careful, politic nature.

${ }^{41}$ Lake, "Lancelot Andrewes," 115-16. The quotations of Andrewes are from XCVI Sermons, 694-95.

${ }^{42}$ Lake, "Lancelot Andrewes," 118.

${ }^{43}$ Lake, "Lancelot Andrewes," 120-30. It is possible that the love of the church festivals is an exaggeration of Laud and Buckeridge, who edited Andrewes's sermons and organized them by feast day. See Peter McCullough, "Making Dead Men Speak," 410. That said, as noted in Chapter Four, Andrewes does highlight the interconnectedness of many of the Christological feasts. For Christ crucified, see also Hooker, V.XXII.9, 97: "That which must save believers is the knowledge of the cross of Christ, the only subject of all our preaching."

${ }^{44}$ The antagonism is not Lake's alone, though his claim that Hooker invented Anglicanism from a sacrament-centered piety may be responsible for this, in my view false, dichotomy; see also Doerksen, Conforming to the Word, 39. For example, in Doerksen, Conforming to the Word, 22, and Centered on the Word, 24, charts the Jacobean via media. "Avant Garde Conformists / Laudians" are "Anti-Calvinist, SACRAMENT-CENTERED, opposed prominence given to preaching, concerned about outer conformity - beauty and orderliness of ritual" whereas "Calvinist Conformists" and "Conforming Puritans" are "Calvinist, WORD-CENTERED, strongly favored preaching, concerned about spiritual conformity to Christ and the Scriptures, accepted church ritual, though with some reluctance in the case of Puritans. Conformists tended toward credal, and Puritans toward "experimental" predestinarian views. See also Veith, Reformation Spirituality, 20-21, whose assessment that American Protestantism is dominated by puritanism, "generally anti-sacramental and non-liturgical," is a useful precursor to his argument that "this dichotomy between Puritans and Anglo-Catholics, assumed by countless literary historians ... is wrong."

${ }^{45}$ Daniel Doerksen, "George Herbert, Calvinism, and Reading "Mattens"," Christianity \& Literature 59.3 (2010): 437. How this belief played out in early modern England may vary, however.

${ }^{46}$ See Hooker, Lawes, 5.LVIII.1, 259, on baptism, where he suggests sacramentalism stems from Christ's words: "Furthermore, seeing that the grace which here we receive doth no way depend upon the natural force of that which we presently behold, it was of necessity that words of express declaration taken from the very mouth of our Lord himself should be added unto visible elements, that the one might infallibly teach what the other do most assuredly bring to pass" (emphasis added). 
${ }^{47}$ Ryrie, Being Protestant, 100, 129. The latter quotation shifts the attention to pastimes and the Sabbath as a whole. Of note is 104, where Ryrie argues that "almost all Protestants, Puritan and conformist alike, accepted the legitimacy of the use of set prayers in both private and public devotions." As Chapter Three and the Conclusion will show, the use of set prayers and forms is not overly controversial until the 1645 Directory of Public Worship outlawed set prayers (but, of course, controversies do not begin overnight). Ryrie later, 214-24, says the debate over extempore prayer becomes dichotomized in the 1640s, but individual critiques appeared as early as 1570 . ${ }^{48}$ Lake, "Lancelot Andrewes," 125-26. It is possible Lake was channeling Herbert's "Resort to sermons, but to prayers most: / Praying's the end of preaching" (409-10). See discussion of this passage in Chapter Four below. The Lake-Herbert connection may also be important because one of Herbert's most direct statements about grace (in "The H. Communion") is that it is an element conveyed through the Eucharist.

${ }^{49}$ Lake, "Lancelot Andrewes," 126, emphasizes public prayer because Andrewes likes the active role that priest and laity play. This connection appears most prominently in Chapter Three, but comes up in discussion of Herbert's "Church Porch." See also Henry Valentine, Private Devotions digested into Six Letanies (London: 1631), 125, which urged "And lastly, people must be here admonished not to depart from the Church till the Minister hath pronounced the blessing."

${ }^{50}$ Ryrie, Being Protestant, 320. 214-238 and 318-28 explores the puzzling attitudes toward the liturgy; 318: "there was a surprising lack of positive interest in the liturgical service" between 1535-1640, which perhaps explains why Andrewes put a strong emphasis on it along with the language of the $B C P$ which, 238, had paradoxical view of "coldly formulaic recitations" while at the same time being a tool to give wing to weak prayers.

${ }^{51}$ The liturgy has a strong sacramental bent to it. Rosemary Fithian Guruswamy, "The Sweet Defender of New England," The New England Quarterly 63.2 (June 1990): 296 notes the use of the Psalter in promoting "the Psalms as eucharistic prayers" and cites Thomas Tymme's Silver Watch-bell.

${ }^{52}$ The Directory functions in part as an ars praedicandi that outlines what a sermon should contain. The $B C P$ simply shows when they should occur during the service. The Baptism order, sig. O3r, does instruct godparents to "call upon [the baptized] to heare Sermons" but contains no follow up action other than to learn the basic tenets of the faith in the creed, Decalogue, and Lord's Prayer.

${ }^{53}$ Bryan D. Spinks, Sacraments, Ceremonies and the Stuart Divines: Sacramental theology and liturgy in England and Scotland 1603-1662, Farnham: Ashgate, 2002, 62: “James's English reign began with disputes about ceremonies, and ended with bitterness and division in Scotland over ceremonies."

${ }^{54}$ Ryrie, Being Protestant, 171-87, concerns gesture in prayer. Quotations here 171-73.

${ }^{55}$ Lake, "Lancelot Andrewes," 128-9. He continues, 129-30, to cite Andrewes's 1606

Whitsunday Sermon, in which Andrewes peaches uniformity for his hearers to "be of one mind, in one place. . . inward and in the bound of peace, that is outward" (XCVI Sermons 599), but the context is of unity inside the church, not specifically in gesture and for an individual's body to match inner and outward.

${ }^{56}$ See more in Chapter One. Though Lake provides examples from 1606 and 1616, perhaps the 1618 emphasis on blending modes of piety shows that the political subtext has changed for Andrewes, who in his 1614 Easter sermon - his most vocal defense of kneeling (at the name of Jesus) - sarcastically quipped that there was superstition in all religious acts. XCVI Sermons, 477: "But it cannot be denied, but there hath superstition beene used in it. Suppose there hath. And almost, in what not? In hearing of Sermons now, is there not superstition in a great many? What shall we doe then? Lay them downe? abandon hearing, as we doe Kneeling? I trowe not; but remoove the superstition, and retaine them still; Doe but even so heere, and all is at an end. . That we set our selves to drive away superstition, it is well: But it will be well too, that we so 
drive it away, as we drive not, all reverent regard and decencie away with it also. . . Sure, heed would be taken, that by taking heed, we prove not superstitious, we slip not into the other extreame." See also Thomas Morton, A Defence of the Innocencie of the Three Ceremonies (London: 1618), 301: "and indeed the bodily parts of man are nothing else but the Organs and Instruments of the affections of his soule." Guibbory, Ceremony and Community 20, cites this passage as an example that "Inward spirituality depends on material worship just as the soul depends on the body in this life." I am not so sure I agree with her assessment that internal devotion stems from the external, however. In support of this, 22, she cites Laud's History and Tryall (full citation in Conclusion): "true and inward Worship of God; which while we live in the Body, needs External helps".

${ }^{57}$ For example, Doerksen "The Laudian Interpretation of George Herbert," Literature and History 3.2 (1994): 37, where he writes "Moderate church leaders, conformist and puritan, cared more about the inner spiritual life than about outward order in the church, but the Laudians reversed these priorities." I maintain that this is a false hierarchy and that Laudianism was not simply a "minority" position within the Church and that the Word- or sacrament-centered piety is a false dichotomy.

${ }^{58}$ Charles Herle, Contemplations and Devotions on the several passages of our blessed Saviors Death and Passion, (London: 1631), 13-14: "A Sacrament is an outward visible signe of an inward and invisible grace; ordayned by God, whereby hee doth seale unto us his covenant of grace made in the blood of Christ, and wee againe testifie our faith and piety towards him: so that it is both a signe in respect of the thing signified, \& a seale in respect of the covenant thereby sealed unto us."

${ }^{59}$ Ryrie, Being Protestant, 8: "Many Protestants were both puritan and conformist. . . But it is a serious error to read those [partisan, post-1640] divisions back into the earlier period. . . This is particularly true with regard to piety and devotion." See also John Reeks, "“Fair Persuasions'? The Implementation of Laudian Altar Policy in the Diocese of Bath and Wells," Reformation 23.2 (2018): 189, who describes his method as "looking forward form the 1630s, rather than backwards from the 1640s." In the Accepted Author Manuscript (the Open Access version of the article), 30, he called his methodology "one which looks forward from the evidence, rather than backward from the narrative of enforcement and resistance established from the 1640s onward." ${ }^{60}$ An important exception is Gene Veith, "The Religious Wars in George Herbert Criticism: Reinterpreting Seventeenth-century Anglicanism," George Herbert Journal 11.2 (1988): 21, who still favors Calvinism but admits the binary is wrong. His distinction between high and low continental Calvinism may be helpful, as low continental Calvinism (which includes Lutheranism) seems to be more amenable to Laudian views of ceremony.

${ }^{61}$ See for instance Doerksen, "George Herbert," 437, for "Protestant interpretations;" Ilona Bell, "Revision and Revelation in Herbert's 'Affliction (I)," John Donne Journal 3.1 (1984): 73-74 of high Anglicanism verse Puritanism and the citation of Nuttall's "Anglican Puritan" who "embraces radical Calvinism," Veith "Religious wars" 19-21, or Seth Swanner, "The Beauty of Ho(me)liness: The Unhandsome Sacramentality of Almost-Shape Poems in George Herbert's The Temple," Studies in Philology 115.3 (2018): 551, for "early modern controversies between sacramental sensuousness and Puritan iconoclasm;" or Richard Strier, Love Known: Theology and Experience in George Herbert's Poetry, (Chicago: University of Chicago Press, 1983), xv-xvi.

${ }^{62}$ Veith, Reformation Spirituality 15-17, also makes this distinction, which allows him to see no contradiction in casting Herbert as Calvinist and a "staunch High Church Anglican."

${ }^{63}$ William Laud, The Arch-Bishop of Canterburie His Speech, (London: 1645), 8. I revisit this quotation in the conclusion.

${ }^{64}$ I first saw Graham Parry to make the distinction of reforming from as opposed to against. "The Tradition of High Church Prayer in the Seventeenth Century" in Prayer and Performance in Early Modern Literature: Gesture, Word, and Devotion, edited by Joseph William Sterrett, (Cambridge: CUP 2018), 37-49; here 45. 
${ }^{65}$ See for instance the citation of Judy Kronenfeld in note two above that dismisses the inward elements attached to external ones. She also writes, 64: "Any view of Herbert's poetry or Herbert's implicit religious position that takes for granted the possible process whereby the human may come to express or participate in the divine, or that assumes that outward or external things by definition, or automatically, express inward or spiritual realities, is tonally wrong for Herbert." See my rebuttal in Chapter Four, which seeks to combine the two.

${ }^{66}$ Quoted in Jean-Louis Quantin, The Church of England and Christian Antiquity: The Construction of a Confessional Identity in the $17^{\text {th }}$ Century, (Oxford: OUP, 2009), 168. Quantin, 113 , identifies a "de facto solidarity between patristic learning and anti-Puritanism."

${ }^{67}$ Doerksen, "George Herbert," 438. He also cites Milton, Catholic and Reformed, 8 and 426-34. While some critics point to the absence of "Arminian-minded" ministers to the Synod of Dort as a support for Calvinism, others have suggested it was a secular-minded political play to avoid war and not an endorsement of James's theology.

${ }^{68}$ Love Known, xi-xix; here xv. xvi also frames Protestantism as separate from the high church movement.

${ }^{69}$ Veith, "The Religious Wars," 19-21, 26-29. Milton Catholic and Reformed, 439; this is pages after Doerksen's citation of the same work (see note 67 above) to show the lack of Laudian continental influence. Less relevant to the project here is the odd aberration in English historical scholarship that temporarily assumed Luther had no influence after 1540 before seeing his influence, especially mediated through Melanchthon. See Ryrie, "The Afterlife of Lutheran England" in Sister Reformations: The Reformation in Germany and England -

Schwesterreformationen Die Reformation in Deutschland und in England. Edited by Dorothea Wendebourg and Alec Ryrie (Tübingen: Mohr Siebeck, 2010), 213-234, which answers his earlier "The Strange Death of Lutheran England," The Journal of Ecclesiastical History 53.1 (2002): 64-92.

${ }^{70}$ As identified in "Lancelot Andrewes's Transforming Passions," Huntington Library Quarterly 71.4 (2008), 574 and his edition of Andrewes's Selected Sermons and Lectures (Oxford: OUP, 2005), xx. The first focuses on Luther's theology of the cross, especially as a visual and audial focus. The careful exception here is that the Eucharistic theology varies between Calvin, Luther, and the Laudians.

${ }^{71}$ This claim is converse of the historicist impulse to cite the writings of Calvin to show Herbert as a Calvinist (even though 1630s English Calvinism had evolved from the writings of Calvin); unlike those scholars, however, here I do not cite corollary examples from Luther.

${ }^{72}$ Hooker, Lawes, V.LVIII.3.261. See also Maltby, 3: "It must be remembered that the Prayer Book is first and foremost 'liturgy'; that is 'work', intended not so much to be read in a passive sense, but to be used, performed, experienced. . . it provided a framework of words and actions to address a wide range of human needs and was intended to involve its participants fully." For a complementary view of Hooker's metaphysical views of participation (one that informs what I call the Andrewesian beauty of holiness), see Paul Anthony Dominiak, Richard Hooker: The Architecture of Participation, (London: T\&T Clark: 2020), esp. 3-12, 62-3, and 72-6. Of note are 3, "participation becomes an attempt to see the world as, in some sense, saturated with divinity," 20, "Hooker offers in Book Five his only real definition of participation as 'that mutuall inward hold which Christ hath of us and wee of him, in such sort that ech poessesseth other," and 72, "the sacraments mark the moment when God imparts the grace of participation."

${ }^{73}$ Ryrie, Being Protestant, 129. Hooker also speaks against idleness, Lawes V.LXX.4.386: "Let us not here take rest for idleness. They are idle whom the painfulness of action causeth to avoid those labours, whereunto both God and nature bindeth them: they rest which either cease from their work when they have brought it unto perfection, or else give over a meaner labour because a worthier and better is to be undertaken. God hath created nothing to be idle or ill employed." 
${ }^{74}$ McCullough, "Transforming Passions," passim. He closes, 587-88, with a reference to Donne's "Goodfriday.1613 Riding Westward" which is a meditation on whether to look upon Christ's crucifix and focuses much on who is facing whom.

${ }^{75}$ Verse printed in XCVI Sermons. Most Bible verses are replicated as they appeared in the relevant primary source; those quotations prefaced KJV or Geneva are taken from Bible Gateway, which uses the King James Version and the 1599 Geneva. The sermon is pp. [1]129-43. This is a rare example of an Andrewes sermon without specific date or occasion. The headnote only alleges it was preached before the King's Majesty at Greenwich in 1607. See McCullough, "Making Dead Men Speak," 412, for note to mistrust the "preached before the King" appellation. On this sermon, see also Iain MacKenzie, God's Order and Natural Law: The Works of the Laudian Divines (Farnham: Ashgate, 2002), 108.

${ }^{76}$ Andrewes mirrors Hooker in this regard. For instance, Lawes V.XXVIII.3.128 argues that the English service balances public prayer with sermons, rather than the Reformed position of "no sermon, no service." See also V.LXVII.1.363.

${ }^{77}$ XCVI Sermons, [1]129, [1]132.

${ }^{78}$ XCVI Sermons, [1]137.

${ }^{79}$ McCullough, "Buckeridge, John (d. 1631), bishop of Ely." Oxford Dictionary of National Biography, (OUP, January 03, 2008); Lori Anne Ferrell, Government by Polemic: James I, the King's Preachers, and the Rhetoric of Conformity, 1603-1625 (Stanford University Press, 1998), esp. chapter five; and Spinks's Sacraments, Ceremonies, and the Stuart Divines, chs. 2 and 3, and The Rise and Fall of the Incomparable Liturgy. See also Chapter One below. While Buckeridge's work extensively concerns kneeling, the gesture is periphery to Andrewes's concern. His 1614 Easter sermon (see note 56 above) on Philippians 2:8-12 would be his exemplary sermon on the act of kneeling.

${ }^{80}$ See for instance Mary Morrissey, Politics and the Paul's Cross Sermons, 1558-1642, (Oxford: OUP, 2011), which focuses on the Paul's Cross pulpit and Anne James, Poets, Players, and Preachers: Remembering the Gunpowder Plot in Seventeenth-Century England (Toronto: University of Toronto Press, 2016), which examines texts (including a chapter on sermons) based on the November 5 occasion.

${ }^{81}$ This against a long tradition of citing random sermons from an author's collected works. Partially due to citation standards, many scholars tend to cherry-pick quotations from Andrewes's sermons without drawing attention to the particular sermon itself. Rather than citing XCVI Sermons, \#, each sermon reference here includes the date and occasion. This is even more specific than, say, Jonathan McGovern who, echoing Nicholas Lossky (a biographer who examined Andrewes's theological viewpoints through XCVI's feast-day grouping of sermon), draws from Andrewes's "political sermons" as one conglomerated group. "The Political Sermons of Lancelot Andrewes," The Seventeenth Century 34.1 (2019): 3-25. While there are certain observations to be drawn from such generalizations, the specific context tries to show a more specific light on the allusion, one that does not assume that the preacher's views might evolve over time.

${ }^{82}$ Ryrie, Being Protestant, 7.

${ }^{83}$ Ian Green, Print and Protestantism in Early Modern England, (Oxford: OUP, 2000) and The Christian's ABC: Catechisms and Catechizing in England c. 1530-1740, (Oxford: Clarendon Press, 1996). C.J. Stranks, Anglican Devotion: Studies in the Spiritual Life of the Church of England between the Reformation and the Oxford Movement (London: SCM Press, 1961). Helen White, English Devotional Literature, 1600-1640, (University of Wisconsin Studies in Language and Literature 29, 1931) and The Tudor Books of Devotion, (Madison: University of Wisconsin Press, 1951).

${ }^{84}$ Davies, 46-50, esp. 47-48: "underlying much current historiography is a notion of Laudianism which is little different from that of Prynne's." 
${ }^{85}$ See John Cosin, The Correspondence of John Cosin, vol. 1, edited by George Ornsby, (Durham: Surtee Society, 1829), letters LXXIII, 126-36, and LXXV, 138-41. In the latter, which may have been written first, Cosin tells Laud, 138-9, he is "resolv'd to make no other answere then Dixi, custodiam, and to take no other revenge upon such intemperate malice then contempt and silence doth upon a scolding and unbridled tongue" against "peevish and vayne" accusations. On the other hand, the former rebuts 32 objections, though it may not be all written by Cosin.

${ }^{86}$ This plays out in other genres as well. See Kronenfeld, 64, who delineates the "political arena" of Donne, with James I's "political hierarchy" (related to "No bishop, no king"), from Herbert's "private, almost mystic piety, put into practice in a country congregation."

${ }^{87}$ The phrase "precise doctrinal allegiance" belongs to Helen Wilcox, ed., The English Poems of George Herbert, (Cambridge: CUP, 2007), xxxiii. In some ways, this argument is Veith's- but his 1988 call for settlement has gone unheeded. Nonetheless, this divide explains Kronenfeld's identification, 58-9, of the "two Herberts" which exist in antithetical readings of Herbert's religion.

${ }^{88}$ Cf. Hooker, Lawes, 5.LVII.6, 259: "We receive Christ Jesus in baptism once as the first beginner, in the Eucharist often as being by continual degrees the finisher of our life."

${ }^{89}$ Debora K. Shuger, Habits of Thought in the English Renaissance: Religion, Politics, and the Dominant Culture, (Toronto: University of Toronto Press, 1997), 1-16, esp. 12.

${ }^{90}$ See for instance Guibbory, "Reconsidering Donne: From Libertine Poetry to Arminian Sermons," Studies in Philology 114.3 (Summer 2017): 561-590, or Nicholas McDowell, "How Laudian was the young Milton?" Milton Studies 52 (2011), 3-22, 253-256.

${ }^{91}$ Davies, 105, also has his own retort to Tyacke: "The problem is that the word 'Arminian' confuses more than it clarifies." See also 89: "it was possible to be reformed in Jacobean England without being Calvinist." 
Chapter One: "I came hither to Preach, not to dispute" - Oratory and Polemic in 1618 Court Sermons

In the middle of his 1590 Doctor of Divinity sermon, Lancelot Andrewes made the declaration "I came hither to Preach, not dispute."1 This statement shows a concern for genre: the rhetorical elements of sermons should edify, not polemicize. Andrewes's dichotomy remains pervasive. At the turn of this century, Mary Morrissey noted that sermon scholars often fail to account for the genre's capacity for both "rhetorical artfulness and their political engagement," where the emphasis on the latter privileges the textual elements over the oratorical. ${ }^{2}$ Recent scholarship has tried to rectify this gap, with editors emphasizing the relatively unique position of the genre: most sermons originate as oratorical performances, highly wrought interpretations of Holy Scripture to exhort auditories to holy living, often relevant to a particular occasion. However, although most preachers crafted sermons with their hearers in mind, we, as readers, approach historical sermons through their printed record. ${ }^{3}$ The printing of sermons, especially those delivered at court, magnifies their polemical potential. ${ }^{4}$ Thus the "rhetorical artfulness" of the preacher is less recognized than his "political engagement."

This sometimes results in diminishing the original context of the occasion, which may result from the scholarly tendency to cherry-pick quotations from a preacher's entire oeuvre, rather than focusing on the context from which the quotation emerges. Instead of looking broadly across a range of sermons, this chapter takes as case study only three sermons, published in 1618 by royal command, to explore the confluence of their immediate hortatory elements with contemporary political impetuses, arguing the importance to recognize the interplay of both elements in their promotion of ceremony 
and gesture. These include Andrewes's 1617 Gunpowder Plot and 1618 Easter sermons and John Buckeridge's 1618 Passion Sunday sermon, which was published with an appended prose tract on kneeling at communion. ${ }^{5}$ When read in chronological sequence, these sermons become more polemical in form and content, moving away from exegesis and into polemics on ceremonial worship. ${ }^{6}$ Of the three, Andrewes's 1617 Gunpowder sermon appears the least polemical; it functions as a typical example of a sermon, outlining worship prescriptions from careful biblical explication. Included in the publication of Buckeridge's 1618 sermon is an appended discourse on kneeling at communion that has long problematized any attempt to read the sermon qua sermon, with the published text amplifying the polemical elements of the sermon at the expense of its hortatory claims. This sermon is the only one of the three publications to have a subtitle, which effectually conflates the discourse with the sermon. Having previously preached on kneeling at Easter in 1614, Andrewes turns in his 1618 Easter sermon to support the authority of the church in establishing holy day observance. This is the most polemical and disputative of the three sermons (disregarding Buckeridge's discourse) and atypical of Andrewes's corpus: it begins with exegesis of a non-liturgical Easter text and shifts into a scholastic catalogue of patristic sources, seemingly out of place in a Protestant, Word-centered sermon. ${ }^{7}$

I argue that reading these sermons in both political and exhortatory senses reveals two separate but interwoven contexts. To read these sermons politically is to recognize that the bishops endorse James's authority as king in prescribing worship practices for the church. To read these sermons as exhortatory recognizes that these sermons blend together elements of external and internal devotion, a synthesis seen most clearly in their 
descriptions of kneeling as an (outward) act of (inner) reverent humility. This blending, where the external enhances the internal, is not commonly recognized in modern characterizations of Laudianism, which assume this ceremonial ideology focuses solely on the external aspects of worship and not the well-being of the listener's soul. ${ }^{8}$ Kneeling, then, plays a role in both modes of reading. It serves as a microcosm for the period's politics with the printing of the sermons spreading royalist propaganda. In their original deliveries, the preachers encourage a more active style of worship that speaks to the local court auditory regardless of their opinion on the king's political agenda.

The year 1618 proves to be quite pivotal in terms of religio-political conflict, and the publication of these sermons by the King's Printing House may explain their political overtones. Peter McCullough has identified the publication of Buckeridge's text as a "landmark in the Jacobean turn toward what would become Laudianism." 9 Two political contexts present themselves as relevant to this claim. The machinations of the Spanish Match to pair Prince Charles with the Spanish Infanta may have manifested a "desire to present a less anti-Catholic face to Spain," which plays out here in Andrews's Gunpowder sermon. ${ }^{10}$ More prominent overall is King James I's support of the Articles of Perth, the result of his 1617 trip to Scotland. These Articles sought to impose five English practices - private baptism, private communion, confirmation by bishop, and more contentiously, kneeling at communion and the observance of Christ-centered holy days - onto a reluctant Scottish presbytery. While the Articles would be accepted by the Perth Assembly in 1618 and ratified by the Scottish Parliament in 1621, they would be abjured in 1638, when the Scottish Assembly would meet to repeal Laud's 1637 prayerbook. ${ }^{11}$ It is perhaps due to this contention that all three sermons explicitly address 
kneeling and holidays. Because of the shared ceremonial themes, scholars often pair these works together as the basis of proto-Laudianism or "Avant-Garde Conformity" but seldom comment on their chronological proximity. ${ }^{12}$

Relatedly, Andrewes reached the height of his ecclesiastical career in 1618. The then-Bishop of Ely was translated to Winchester and named dean of the Chapel Royal. In the latter capacity, he was responsible for the appearance of James's chapel, which may have been the model for the Laudian "beauty of holiness," an idea that Andrewes first references in his 1617 sermon. ${ }^{13}$ Andrewes's promotions raise an insightful, if speculative, question: do his sermons of 1617 and 1618 reflect political scheming and, if so, does the politicization of his sermons come at the expense of his auditory's edification? For a preacher known for his "characteristic avoidance of outright engagement in controversy from the pulpit," a reversal of method is no insignificant matter. ${ }^{14}$ (Because Buckeridge was already Bishop of Rochester in 1618 and would receive no further promotion until his 1628 translation to Ely, the same question cannot be asked of him to the same effect; however, as this was his last recorded sermon at court, his polemics, despite the royal printing, may have lost him favor under James). While these sermons were all preached to the London court at Whitehall, their 1618 printing allows two more potential audiences, the Scottish Kirk and puritans abroad. ${ }^{15}$ 
I. "We bethinke our selves: how to doe him Service. . Reverently to performe holy dueties: Laudably to have our conversation among men" (2, 25-6).

Andrewes's 1617 Gunpowder Commemoration Sermon is comparatively straightforward because it uses generic conventions that stem from applying the sermontext to the auditory. Although the political subtext adds a sense of urgency to the style of worship Andrewes promotes, the sermon, even without the background knowledge of Perth, still clarifies proper worship for the sake of order and decency. While Andrewes does chastise those who turn sermon-hearing piety to idleness, his exhortation does not rely on polemical abuse. His lengthy exegesis of Luke 1:74-75 promotes a liturgical practice that frames gesture and worship in terms of service, performed in holiness and righteousness. In identifying the sermon-text as the $7^{\text {th }}$ and $8^{\text {th }}$ verses of the $B C P$ 's Benedictus, the textual headnote adds a further liturgical ethos to the sermon. For comparison, Buckeridge's sermon makes no similar gesture identifying his sermon-text of Psalm 95:6 as part of the Venite Exultemus. ${ }^{16}$ The organization of the sermon itself reflects a standard sermon methodology. Andrewes uses a Ramist-like divisio to apportion this text into a conditional that focuses on the duty of Christian service, performed through liturgical adherence in worship. Thematically, Andrewes simplifies the Latin verse to [liberati] ut serviamus Illi to reflect the occasion for the sermon: because God delivered the English (from the Gunpowder Plot), the English should serve God. His exegesis relies on breaking down the English text phrase by phrase. The text prints the verse in English with more commas than appear in the Authorized Version: "That we being delivered, from the hands, of our enemies, might serve Him, without feare | In holinesse, and righteousness, before Him, all the dayes of our life" (sig. A2v), 
Andrewes uses each comma phrase as a subdivision, describing either God's role in delivering from the hands of the enemies, or the Christian's in serving God in both holiness and righteousness (5-7). Each part of the sermon reflects the keywords of the sermon-text, holiness and righteousness, with the exhortation that Christian practice should reflect Godly attitudes.

Overall, this sermon resembles others Andrewes delivered on the Gunpowder anniversary, but his polemical attitudes are more understated than in previous sermons, probably due to the political atmosphere at court with the impending Spanish Match. Andrewes often uses the occasion to lay out worship prescriptions in strong anti-Calvinist or anti-Jesuit tones, polemicizing through indirect satire of actions rather than dissecting explicit statements of belief. ${ }^{17}$ In 1617 , Andrewes's anti-Jesuit satire is even more circumlocutory than his earlier sermons. For instance, at the first commemoration in 1606, Andrewes describes the occasion as the English Purim, worthy of the feast-day celebration that James instituted. The Jesuits, he argues, would have turned the occasion into a holiday had the plot succeeded. ${ }^{18}$ Andrewes, whose consecration as Bishop of Chichester days before the plot meant that he would have been present at the explosion, imbues a particular pathos into his sermon. This pathos continues in 1617, deliberating on what would happen, had their "roaring enemies" brought "ruine" to "English haereticks" $(12,16,14):$ "All the world knows, if the plotte had gone on, and the powder gone off, the whole land should not have scaped ut serviamus: But should have served duram servitutem, been not in service, but in servitude. . A blessed exchange for us. Great oddes ... betweene Godes service, and their servitude; their bondage, thralldom, slavery, tyranny, I cannot heape too many names" (23). All of this emotional hedging provides an 
external impetus for the English to serve God through worship. Throughout this, Andrewes chooses his enemies carefully - he references the Spanish Armada, but not the Gowrie plot against James in Scotland. Despite the references to the Armada, usually as "88," Andrewes coyly avoids disparaging the Spanish directly and identifying the enemy as Catholic or Jesuit, as he did in his earlier sermons. ${ }^{19}$ Given that the Articles of Perth invoked holy days, though only those related to Christ's life, it may be surprising that Andrewes does not use the occasion, as he had in the past, to defend the November 5 feast-day occasion or make comparisons Christ's Easter deliverance. ${ }^{20}$ He does however include these elements in his 1618 Easter sermon, which is more polemical in its defense of the church establishing customs than the description here of holy service. ${ }^{21}$ This November sermon, however, exemplifies Andrewes avoidance of controversy, at least regarding Catholics.

The political subtext of this sermon, the Article of Perth concerning kneeling, explains Andrewes's brief polemical attack that targets what are commonly considered puritan attitudes. Typical of his reluctance to be overtly polemical, Andrewes avoids direct engagement in controversy here by offering only a subtle endorsement of gesture. ${ }^{22}$ His ceremonial prescription is consistent here with his portrait as Avant-Garde Conformist. Andrewes's methodology reflects the view of the true church as descended from the Primitive Church, here supported through scriptural examples and not patristic authority. Andrewes's polemical moment targets Calvinist practices that lack adoration and reverence. Citing Psalm 95:6, "Let us worship, and falle downe, and kneele before the Lord Our Maker," Andrewes argues that the English should, on a daily basis, follow the precedent of the primitive church, who took this Psalm, the Morning Prayer's Venite, 
as the "first voice" in their worship, with kneeling being the "first thing they did" before all else in their service (30). As exempla of serving God through kneeling before his majesty, he cites both the saints in heaven, via Revelation 4:10, and a number of Old Testament saints on Earth. The pinnacle of this argument is Malachi 1:7, "The Table of the Lord is not regarded," from which Andrewes argues: "No service then: no servants there: but bidden guests, haile fellowes, homely and familiar, as one neighbor with another" who take the communion without blessing and invocation. "Both which, invocation, and receiving a blessing," he continues "were never done, but de geniculus" (33-4). This is a rare moment where Andrewes does not translate the Latin "from the knees." The lack of translation, which may not have been necessary given the general knowledge of Latin, may focus the auditor's attention to the aspect of service that underlies the gesture itself. ${ }^{23}$

It is worth nothing that, for a normally sacramental Andrewes, this is one of the few references to communion in this sermon, and it is not in his conclusion, as would be typical. Where he usually ends his feast-day sermons with explicit calls for Eucharistic participation, Andrewes substitutes a soteriological reference to the Christian's "final reward of our service," which is a "Grand deliverance in Benedictus" (49). That Andrewes, in the middle of his sermon, refers to kneeling at communion is significant. On the one hand, the single-most contentious element of kneeling in Reformation England is during communion. ${ }^{24}$ Alternatively, the reference makes allusion to another liturgical element of Andrewes's sermon-text, not as it appears in the Benedictus, but in the Service of Communion in the prayers of confession, which end in giving thanks, "studying to serve him in true holinesse and righteousnes all the dayes of our life" before 
imploring the communicants to "take this holy Sacrament ... meekely kneeling upon your knees. ${ }^{" 25}$ On the one hand, gesture is less important than the sacrament, but, on the other, gesture emphasizes the humility of the Christian on such a grand occasion. Those who oppose kneeling tend to be of a Calvinist persuasion, with the preference for sitting inviting critiques of homely, irreverent behavior by acting as coequals to divinity.

This subtle endorsement of gesture, where the external is a result of and downplayed in favor of internalized piety, speaks to another Laudian context, the "beauty of holiness. ${ }^{" 26}$ This sermon is the lone reference in Andrewes's sermon corpus to the beauty of holiness - a fitting reference given the proximity of the sermon's publication to his promotion to dean of the Chapel Royal in the same year. Unlike the politicized 1630s campaign, Andrewes's version does not focus on the accoutrements of the church - the normally effusive preacher only mentions "décor" once without elaborating on its beauty. ${ }^{27}$ For Andrewes, the beauty of holiness is a call to reverent worship inside the church. In this sermon, the allusion comes after Andrewes's anti-Calvinist critique, which rests on two facets: a perceived lack of reverence in the homeliness of sitting at communion and the reduction of "all our holinesse" into the hearing of sermons, to which Andrewes quips "All our Service, eare-service: that were in effect, as much to say, all the body were an eare" (35). ${ }^{28}$ In language Andrewes will repeat five months later at Easter about sacraments and ceremonies, Andrewes comments that "truly, it is a notable Stratageme of Sathan, to shrinke up all our holinesse, into one part: and into that one, where wee may bee or not be: Being, heare or not heare: Hearing, mind or not minde: Minding, either remember or to forget ... Only, stay out the houre (if that) and then goe our way" (37). ${ }^{29}$ In a public service, Andrewes argues that sermons offer no proof of 
attention or way to demonstrate piety as there is no "righteous doing" in "holy hearing" (40). ${ }^{30}$ It is worth noting that Andrewes purposefully "meddle[s] not" and "leave[s] it to God" to deal with holiness performed in secreto sanctoru $[m]$, in the privacy of the house, that he hopes "is better, and more service-like, then our outward is." He focuses on service in Synagoga, arguing it "is growen too familiar, and fellow like; Our cariage there, can hardly be termed service, there is so very little of the servant in it" (28). The problem, however, is the overlap, where the private bleeds into the public - Calvinists decry kneeling as a private act done in public; ceremonialists see sitting as private act unbecoming the gravitas of the Lord's presence. ${ }^{31}$ Andrewes's beauty of holiness is important because when Christians are "abroade" from the Church, where "neither Word, nor Sacraments, nor Co[m]mon Prayer, [are] there," they cannot serve with holiness and righteousness. "Onely there [in the church]" he continues, may "we serve Him in his Name" (38). ${ }^{32}$ This sacerdotal emphasis (all three elements, if we take the "Word" to be the "Word preached," require the priest to mediate between God and laity) is not to say that private worship is unimportant but that closet-prayer does not take place in a sanctified location with God's presence. ${ }^{33}$

For Andrewes, private worship practices lack decency and order befitting God's presence. Referring to his sermon-text, Christians direct their worship, proffered in righteousness and holiness, coram ipso - "Before Him" (who delivered us). Where else is this best done than in the temple, Andrewes asks.

When we come, before the presence of the Lord, the presence of the Lord of the whole earth, (so the Psalme doubles it, to make us thinke on it the better) then, saith he, worship him in decore sancto, in a holy kind of decencie, or (as we read it) in the beautie of holinesse. Our holinesse should have a kind of beautie with it ... Now this is that, the world complaines of; there is not that decor, that beautie: not that honour ... that venerable grave behavior, in our holiness, we cary not 
ourselves in his holy Sanctuarie, where our holinesse should be at the holiest, nor at His service there, as servants should, and use to doe. (29-30)

The context of this makes clear that Andrewes is not focused on the layout of the church itself, but how to worship in God's presence - Andrewes repeats the words holy and holiness more often than beauty. Like Hooker, who perhaps first appropriated Psalm 96:9 (KJV: "O worship the Lord in the beauty of holiness") to refer to the temple, Andrewes's concern is with the seriousness of behavior before God's presence. ${ }^{34}$ Beauty accompanies, rather than replaces, holiness. In worship, this beauty reflects God's gift to humanity: Christian service stems from redemption. ${ }^{35}$ While the beauty of holiness becomes more contested in the 1630s, here is a call for reverence without reference to the orientation of the altar or altar rails. ${ }^{36} \mathrm{We}$, Andrewes argues, are at our holiest while in the church and receiving the Eucharist, so actions should reflect the inner humility of recognizing our stature before God. Christians recognizing that they serve God and not man is what differentiates the kneeler from a hypocrite doing "mock-service." ${ }^{37}$ It is only after advocating for a beauty in holiness that Andrewes, five pages later, suggests that Christians should receive their blessing and invocation de geniculus, "when wee are at the holiest" (34). ${ }^{38}$

For Andrewes, corporate worship offers a better solution for Christians looking for outlets to serve than sermon-gadding, the widespread practice of attending multiple sermons in a week. Ironically, Andrewes uses his time in the pulpit to promote participation in the entire service, not just the sermon (which would be less surprising if this sermon ended, as many of his do, with a call to partake in the sacrament). ${ }^{39}$ His defense stems from the etymology of liturgy, which is both service and common prayer: 
$\lambda \alpha \tau \rho \varepsilon v ́ \omega$ [latreúō] the word here in my Text. It is no new thing . . . For though there bee other parts of Gods service: yet Prayer hath borne away the name of service, from them all. עבידה [ and that is, service. And the Greekes, theirs, $\lambda \varepsilon ı \tau o v \rho \gamma i ́ \alpha$ [leitourgía], and that is so, too. And wee, when we say, At Service time, and the Service booke, and refuse to be present at Divine service, meane so likewise. And, God himselfe seems to goe before us, and direct us so to doe [in his House of Prayer] . . . As indeede, when all is done, devotion is the proper, and most kindly worke of holinesse: and in that serve we God, if ever wee serve him. Now, in what honour, this part of holinesse is; what accompt we make of this service, doe but tell the number of them that bee heere at it, and ye shall neede no other certificate, that in His service we serve Him but slenderly. $(34-5)^{40}$

This passage, where service literally means liturgy, leads Andrewes into his rant against the perceived piety of going to a service just to hear a sermon. In participating in the worship service, Christians demonstrate fully their devotion, unlike sitting at sermons where they may or may not meditate upon the preacher's words. This problem, however, is not unique to the Jacobean court. Andrewes again cites the primitive church, where "the Sermon was ever done, before the service begun ... when they went to service, when the Liturgie began, all these were voided; not one of them suffered to stay" (36). ${ }^{41}$ With this line of thought, it is not hard to see why Andrewes emphasized the full service amidst the Jacobean (often read Calvinist) preference for sermons, as it offers more opportunities for one to serve in body and mind. ${ }^{42}$

II. The Duties of the whole man: "Give me leave to joyne these three, Adoration, Prostration and Kneeling together: because in trueth they should never be separated" (10)

Ceremonial conflict also plays out in Buckeridge's sermon, in which these antiCalvinist criticisms appear amid ostentatious royalism. While the sermon asserts prominently the role of the king in administering worship practices, the appended discourse on kneeling at communion, despite giving the published text a polemical flair, 
both refines and mollifies Buckeridge's overall argument. Given David Calderwood's dismissive citations in 1619, Buckeridge's work had clear contemporary resonances with the Scottish controversies. ${ }^{43}$ However, the publication of the discourse with the sermon has frustrated attempts to read the sermon itself as a sermon, with scholars citing the discourse interchangeably with the sermon. ${ }^{44}$ This frustration is perhaps amplified through Buckeridge's limited surviving printed sermon corpus, all closely linked to Andrewes, that provides few options to mine for his radical theological positions. ${ }^{45}$ The frustration begins with the title: A Sermon Preached before His Maiestie At Whitehall, March 22. 1617. being Passion-Sunday, Touching Prostration, and Kneeling in the worship of God. To which is added a Discourse concerning Kneeling at the Communion. Aside from the resultant confusion of the legal year changing to 1618 on $25 \mathrm{March}-$ some have misdated this sermon, thinking that Buckeridge took a full year to produce the discourse - the title page (over)emphasizes the controversial nature of Buckeridge's sermon. ${ }^{46}$ While the sermon certainly touches prostration and kneeling in worship, the title-page leaves out adoration, the key action derived from the sermon-text that Buckeridge frames inextricably from the imperative to perform bodily gesture. This title minimizes Buckeridge's repeated calls to humility and compunction that mark the sermon as one appropriate for Passion Sunday. The very premise of the sermon requires working out the disjunction between using a hymn of adoration (the venite adoremus of Psalm 95:6 - printed as "O come, let us worship, and falle downe, and kneele, [or weepe] before the Lord our Maker") for a solemn and penitential Lenten reflection (sig. A2v). ${ }^{47}$ The publisher, in highlighting the gestures rather than the devotional acts that inform them, draws out the polemical elements more than the devotional. 
To get the most out of reading Buckeridge's sermon as a sermon requires ignoring the polemic discourse in order to focus on the preaching of the sermon-text and its relationship to its occasion. Doing so allows us to see how Buckeridge makes the external act of kneeling representative of inner humility. In contrast to Andrewes's liturgical motifs, neither Buckeridge nor the printer make explicit the verse's relation to the liturgy. Though he identifies the Psalm as beginning with "rejoycing, Venite exultemus; O come let us sing unto the Lord, or exult" (Psalm 95:1), Buckeridge does not equate the Psalm with service-book observance (1). ${ }^{48}$ Buckeridge's omission may stem from the sermon's emphasis on all worship, not just worship during church services or, as in the discourse, communion. Despite the title page's repetition of "kneeling," humility stands at the core of Buckeridge's oration. Where Andrewes emphasizes holiness and righteousness in service, Buckeridge argues that adoration, prostration, and kneeling (or weeping) are inextricable parts of the worship of God, all of which stem from "humiliation." His task is to turn his sermon-text, a call to exultation (venite ad exultationem), from a "Text of mirth" into a "call to humiliation" (venite ad humiliationem), appropriate for "a day of greatest sorrow, that is Passion Sunday" (1-2). (There exists a certain Laudian ethos especially in light of the Article of Perth administering the Christological festivals - to Buckeridge emphasizing Passion Sunday, repeatedly highlighting a somewhat forgotten holy day). ${ }^{49}$ This redirection to humility allows Buckeridge to foreground adoration, prostration, and kneeling as acts of repentance and subservience to God the creator, rebuffing those arguments that kneeling is inherently superstitious or vain. These acts reflect inner humility and are devoted to the Godhead alone for Christian salvation and judgment. $^{50}$ 
For Buckeridge, as for Andrewes, gestural worship mandates inner devotion. ${ }^{51}$ Where Andrewes consistently emphasizes the presence of decency and order in gesture, Buckeridge here explicitly balances the outward with the internal. ${ }^{52}$ Buckeridge's division of the sermon shows this balance: in coming together for God's worship (heeding the king's venite), Christians bring “Latria, divine Adoration: Adoremus, Let us worship with the inward devotion, and sacrifice of the heart" followed by "servitus, Service or outward worship of the body: procidamus, Let us prostrate our bodies together with the inward intention of our Soules" joined with "Contritio, Contrition and sorrow: Genuflectamus, or ploremus, Let us kneele and weepe for our sinnes," all of which is to be tendered to "Majestas, or major status, the Majestie or greatest state, to whom this worship and repentance is due; Coram Domino qui fecit nos, before the Lord our maker" (2-3). This breakdown resembles Andrewes's righteous and holy worship seen in the beauty of holiness. It is the "whole man" Buckeridge preaches that "must be offered up as a living sacrifice to God ... that the whole man being in the Temple, may at the same instant be presented to God in Heaven" (7). ${ }^{53}$ Though Buckeridge distinguishes service as bodily, outward worship, service joins those other elements. It is only once a Christian focuses their heart on the inward devotion that they can enact reverent piety within the Temple. ${ }^{54}$ Service and adoration require reflection and the attention of the heart (17). ${ }^{55}$ Buckeridge reiterates the distinction multiple times, and, in a view that surely would have been amenable to his Calvinist critics, he preaches that "God cares not for the outward, nay hee loathes it, if the inward be wanting" (12). ${ }^{56}$ The opposing (often Calvinist) claims of superstition assume that the inward is nonexistent in external displays. 
Appropriate for a non-disputative sermon, Buckeridge does not give space to those dissenting critiques of kneeling here as he does in the discourse. His rhetoric, however, critiques those who do not align with his view. Throughout his sermon, Buckeridge speaks of kneeling and gesture in the broadest senses - in prayer, contrition, and, most contentiously, at communion. ${ }^{57}$ This sermon references communion twice. The first is scant, where Buckeridge argues that the "undivided companions" of inward adoration and outward worship "must be tendred at the Altar of The Lord our Maker" (3). Buckeridge is careful with his preposition: worship is directed at the altar, not to it. Such a distinction aligns him with Andrewes's "beauty of holiness," where the worship in the sanctuary reflects the holiness of the heart and avoids the potential accusation of idolatry that worships the altar instead of God. Though a fine distinction, Buckeridge's discourse repeatedly distinguishes worshiping God's presence in communion from the perceived Catholic practice of worshiping the elements themselves: "I doe not say, the Sacrament or element, but Christ himselfe, and it was the practise of all the Saints and holy men [of the universal, purer Church] to adore with bowing and kneeling" (13; see also 33-35). In the sermon's second anti-Calvinist critique, Buckeridge again echoes Andrewes in attacking the familiarity exhibited by those who sit at communion: "this externall worship of kneeling is opposed by those, that love their ease more then their dueties, and therefore cannot endure to kneele, or stand, but must sit at their devotions, which is contrary to all discipline, and sit at the Lords Table, as if they were equall guests with him, else wee shal bee Idolators" (12-13). Buckeridge supports this claim first by citing Augustine's commentary on Psalm 98 before moving into biblical exempla, including Old Testament patriarchs, the wise men, and Christ. He ends, comparing puritans to "these Elephanti, 
Elephants that have no joynts in their knees, have sworne and vowed that they will not kneele to God, and his Christ, that they make it knowne that they esteeme their owne phantasie more then they doe the oath of God" (13-16). ${ }^{58}$ Buckeridge argues that if the most esteemed men in the Bible can humble themselves to kneel before God, then English Christians can display similar piety, especially when they have no scruples kneeling before their earthly king. Though anachronistic, Herbert's "The Church-Porch" (c. 1633) contains a relevant paraphrase of the attack against presumption: "Kneeling ne're spoil'd silk stocking: quit thy state. / All equall are within the churches gate."59 The allusion is particularly apt, given the poet's abdication of the court (with its purported Calvinist consensus), which is where Buckeridge delivered this sermon.

While the selected quotations of Buckeridge reflect anxieties over the controversy of kneeling, in preaching the role of the king in worship, Buckeridge displays other political concerns stemming from James's attempts to reform Scottish practices. Buckeridge insists that it is the king, as head of the church, who calls Christians to worship. The very opening of the sermon draws attention to David's authorship of the Psalm and focuses on David-as-king, which comprises one-fifth of the sermon's length. Given the developments at Perth, this is not accidental. Though Buckeridge contends that kings are not prophets, kings nevertheless "hath power to call all, both Priest and people, Venite, Come, let us goe together to Gods worship" which contains "externall coaction" not present in the priests' own calls $(2,5) .{ }^{60}$ Buckeridge makes clear his political allegiance and that he preaches to both England and Scotland:

All his Kingdomes must be obedient to his venite, and joyne together, not only in unitate, in the unitie and substance of Religion, and worship of God, but also in uniformitate, in uniformitie of outward order and ceremony of Gods service, if possibly it may; especially in all the parts of my Text, of Adoration, and 
Protestation and kneeling, which are not ceremonies, but parts of Divine worship; and for disobedience must be subject to his coercion, who beares not the sword in vaine. $(8)^{61}$

Uniformity - the rallying cry of the first Hampton Court Conference, made manifest in the paratextual materials to the $1604 \mathrm{BCP}$ revision - was no foreign topic to the court pulpit: prior to the three sermons discussed here, the last royally commanded sermon was Robert Wilkinson's Barwick Bridge: or England and Scotland coupled. In a sermon tending to peace and unitie, published in 1617 and preached before the king in Scotland. The primary focus of that sermon was unity, though it contains a brief mention of ceremony and garb. ${ }^{62}$ With this talk of unity, it is perhaps easy to overlook Buckeridge's brevity in declaring that adoration and kneeling "are not ceremonies, but parts of Divine worship." While elevating kneeling beyond ceremony is a radical idea, Buckeridge waits until later on in the sermon to expound on that idea.

Before arguing his theological position on kneeling, Buckeridge concerns himself with those who misdirect their focus in worship. Buckeridge's politics are perhaps typical of what one might expect from a bishop preaching on the propriety of ceremony. Buckeridge follows the king's venite with a confusion of other calls that mislead worshipers. Amidst these other calls, Buckeridge argues that "this Religious call, Venite adoremus, Come let us worship God, is scant heard or regarded" (10). This leads into what might be the most famous passage of the sermon, where Buckeridge satirizes the Calvinist emphasis on sermon hearing. Having preached the importance of the whole man's living sacrifice, Buckeridge turns his attention to those who bring but a part of themselves to worship:

It is not said, Venite, audiamus, Come let us heare, as those doe that turne . . . Temples into scholes, and all adoration and worship into hearing of a Sermon: as 
if all, soule and body, were turned into an eare . . Hearing, indeed, is a good part of Christianitie, but it is but a part: and faith comes by hearing, but faith, hope, and charitie, Justice, and Religion, are not hearing, but the fruits of hearing: and therefore no man may thinke that he hath given God his due worship, if hee have heard God speake by his Minister: as if a man had observed the Sabaoth well, if they have heard reverently, as some Catechismes teach: much lesse may they thinke, that they have done all their duetie, that have slept or talked out a Sermo[n], or heard it, but not regarded it. (10-11)

The complaint has strong echoes of Andrewes's “eare-service." This is not so much Buckeridge's attempt to "minimize preaching and sermons" (as claimed in Doerksen's analysis of the "custodians of order") but a critique levied against those who privilege sermon-hearing over sacramental observance or, worse, hear sermons but are not stirred to any action whatsoever. ${ }^{63}$ Buckeridge's complaint also identifies divergent views on proper observance of the Sabbath and criticism of some popular catechisms, all of which play into Calvinist and anti-Calvinist debates. ${ }^{64}$ The core of the hearing debate centers on whether hearing and contemplating are religious duties. Compared to Calvinism, Laudian piety is more active, focused on doing, as in James 1:22. For the Laudians, hearing internalizes devotion, but gesture externalizes it for God.

Much of what makes this an effective sermon are Buckeridge's exhortations for his auditory to use actively their bodies in worship. However, the above complaints are fairly benign. This sermon contains two points of departure from typical proto-Laudian positions. The first is relatively innocuous, though it harkens back to Catholic devotional practices. In his calls to humility, Buckeridge tells the auditory to look upon Christ on the Cross and offers an apocryphal quotation of Christ: "hearken what Christ sayth to us from his Crosse, Vide quae pro te patior, Behold, $\mathrm{O}$ man, what sorrow Christ suffered for thee upon his Crosse; and let his sighes and teares move thee to compunction" (22). The text offers no marginal citation of the source of this saying, though it is a popular medieval 
devotion, stirring one towards penitence. Such a cruficix-oriented plea, while not entirely out of character for Lenten devotions (as McCullough has shown), seems misplaced in what is usually considered a Calvinist-leaning court. ${ }^{65}$ However, Ryrie notes that Protestant devotions on the passion focused on the mental anguish rather than the affective elements, with reflections on the passion commonly being associated with "sacramental devotion" - Buckeridge's admonition here is affective, though not explicitly sacramental (the tie between ceremonial observance and the sacrament is more a concern for Andrewes in his Easter sermon, below). ${ }^{66}$

More radical is Buckeridge's adamance that kneeling is not a ceremony. The debate over ceremonies is traditionally relegated to adiaphora - things indifferent to the salvation of mankind. Kneeling has been swept under this indifferent rug, which gave theologians some flexibility in their defenses. With his departure from that tradition, Buckeridge breaks a lineage that includes Hooker and Andrewes - though he partially contradicts himself in the ensuing discourse. Caught up in the rhetorical flourishes of preaching, Buckeridge goes to great lengths to describe the importance of what Hooker simply calls a "gesture of piety." ${ }^{97}$ For a passage that includes Buckeridge at his most radical, it is surprising that the following has not received more in-depth scholarly attention: ${ }^{68}$

This Prostration and kneeling is not so much a ceremonie, as a part or duetie in divine worship, not to be omitted but in case of necessity; as our Saviour that kneeled in the garden, did not kneele at his prayers on the Crosse, because hee could not kneele ... [Buckeridge catalogues Old Testament examples of Moral Law and refutes that the Law of Nature touches ceremony so he can conclude] so Prostration or kneeling is a duetie.

Ceremonie is named a Carendo, of want; because the soule that wants other meanes to expresse it selfe, doth it by signes and gestures. And in heaven where grace and glory are received immediatly without any Sacrament or Ceremonie at all, there can bee no Ceremonie: and yet the Elders in Heaven cast 
downe their Crownes and fall downe, and worship him who sitteth on the Throne, and therefore kneeling or bowing is a duetie which may not be omitted as an indifferent thing in the solemne worship of God. (17-18)

Without using the word adiaphora, Buckeridge admonishes that kneeling is a crucial part of worship, closely related to sacraments. Not surprisingly, Buckeridge quickly moves from this declaration to reiterate the joining together of adoration and gesture, without belaboring his controversial stance. The margins contain two notes, to Revelation 4:10 (also cited by Andrewes above) and a potentially misleading reference to Augustine's Retractions, 2.37 - Augustine talks about singing Psalms before and after distribution, not about requiring gesture as a Christian duty.

In the attached polemical tract, Buckeridge extends themes of the sermon but shifts to privilege the institutional role of the church, which happens to be the polemical focus of Andrewes's 1618 Easter sermon. While the focus of Buckeridge's tract is the same as the sermon - the "humiliation of outward man . . the humilitie of the inward" Buckeridge focuses more specifically on communion and does so in a more typically polemical manner. He says he was "occasioned to descend to the particular of the Sacrament of the Lords Supper," which should be unsurprising given the Articles of Perth $(29,33)$. While kneeling is still a duty that "must bee received with reverence, adoration, and kneeling," Buckeridge hedges away from that statement in the conclusion, rerelegating it to a ceremony. ${ }^{69}$ In the 28-page sermon, Buckeridge makes only seven patristic references; in the discourse, it takes only three pages to reach seven references, including councils. Here, more typical of polemics, he cites a multitude of patristic sources and weighs them almost equally to biblical references, whereas the sermons rely on scriptural bases. ${ }^{70}$ The discourse has two parts. First, Buckeridge lists six reasons for 
kneeling at communion, addressed against those "who out of an affected tendernesse, refuse to kneele in the worship of Christ, for feare they should commit Idolatry with the sanctified creatures" (33). He also argues against those who consider kneeling an act of private worship, which is unlawful when performed in public worship. As with the Coram Deo arguments in the sermons, Buckeridge distinguishes that English adoration is toward God, not the specific elements, which he dismisses as Papist superstition and cites Calvin in support (42) ${ }^{71}$ The second half of the work lists the reasons for sitting, which are eight reasons pulled from an unnamed work that Buckeridge refutes piece-by-piece. ${ }^{72}$ His conclusion supports a king- and bishop-led church. He argues that the prince and prelates established the practice of kneeling in the Church of England, even though the practice is "ancienter than Popery." He also believes "there is sufficient power in the Church to declare it [kneeling a ceremony or duty] ... upon good reason of decencie and order" to promote unity and uniformity. He then repeats that "the Church that hath a power to institute and establish Ceremonies in matters of decencie and order, hath appointed this gesture of kneeling" (243-44).$^{73}$ The scriptural basis for this position comes from 1 Corinthians 11, in which Paul argues that the Church has a right to institute rites and ceremony. This is also the verse from which Andrewes bases his 1618 Easter Sermon, which focuses more on the authority of the church than the auditor's benefit of partaking in ceremonial observance. 
III. "The custome of Easter made a contention, would make it an Easter day Text" (1)

Andrewes's 1618 Easter Sermon may be the most atypical and non-liturgical of his entire corpus, which can be attributed to the influence of defending the Articles of Perth. The sermon divides nicely into two parts: a somewhat exegetical sermon on the observance of ceremonial rites stemming from 1 Corinthians 11:16 (pp. 1-23) and a scholastic lecture on the observance of Easter (pp. 23-51) that consists of an exhaustive catalogue of patristic exempla. These comprise his argument for the church's authority to institute holy days. His rhetorical finesse is on fine display throughout this sermon as he specifically avoids mentioning any Scottish troubles associated with Perth. This omission is the opposite rhetorical gesture of praeteritio or apophasis, both of which "ignore" a premise they nevertheless name (cf. de geniculus above). In light of the Articles on ceremonial observance and the implementation of holidays surrounding Christ's life, this sermon works as a sort of allegorical enthymeme that implies the premise of Perth. His second premise is the church's establishment of the custom of Easter. He concludes that the Church has the right to establish rites and holy days. According to Laura Stewart, the Kirk often administered communion at Pasch and Yule by 1617, so Easter itself was less a controversial site than the whole slew of holy day observances, which is Andrewes's eventual conclusion. ${ }^{74}$

The initial exposition of the sermon-text resembles many other of Andrewes's sermons, except for the fact that the text has no immediate relevancy to the occasion of Easter and is not one of the day's $B C P$-assigned readings. ${ }^{75}$ Yet, Andrewes makes the text have controversial relevancy. The sermon-text is 1 Corinthians 11:16: "But if any 
man seeme to be contentious, we have no such custome, neither the Churches of God." Atypical of the liturgically minded preacher, Andrewes begins "[T]HIS is no Easter Text, as wee are wont to have: Nothing of the Resurrection in it. It is not for the day" before hedging that "It is not, not directly." The text connects to the occasion only through a subjunctive conditional: "But if it should happen there were any co[n]tention about Easter, that would bring it within the word contentious here. Specially, if that contention about Easter were, whether it hath bene ever a custome in the Church of God ... The custome of Easter made a contention, would make it a Easter day Text" (1). ${ }^{77}$ As he soon elaborates, there was historical contention over the celebration of Easter; though it was more of when to celebrate it rather than if to celebrate.$^{78}$ Momentarily ignoring the Perth controversies, it would appear that Andrewes delivered a 50-page sermon on Easter about Easter, but not resurrection or salvation, over a non-controversy. Despite (or, in light of) this, Andrewes returns to form at the end of his sermon: typical of his feast-day sermons, the final proof involves the ceremonial observance of the Sacraments on Easter. Citing St. Ambrose's $83^{\text {rd }}$ Paschal Epistle, Andrewes's last, summative words invite the auditory to partake in "this feast of our common Salvation" by "Ensuing the steppes of the Apostles and the Churches of God (all:) with whom joyning both, let us expect the blessing of God upon us" (50-51). The parenthetical all highlights for Andrewes that the sacrament - and its ceremonial observation - is a universal practice of the Church, not divided by geo-political boundaries or rulers.

Though the patristic catalogue is more overtly disputative (though he seeks to bury the unnamed opponent in evidence, rather than attack their position), Andrewes's beginning biblical exhortation on the observance of ceremonial rites likewise concerns 
itself with contested practices. Paul's epistle considers the adiaphora of ritual participation, which though indifferent, can lead to a slippery slope of undermining sacraments if the contentions about customs go unchecked. Andrewes applies these concerns to outward order: "For what then were these? for nothing, but a matter of Rite ... It was not about any the high mysteries, any of the vitall parts of Religion, Preaching, Prayer, the Sacraments: Onely, about the manner, how: the gesture and behavior, wherewith: in what sort, to cary themselves, at Preaching, Prayer, the Sacraments: about matter of circumstance meerely, and nothing else" (8). Andrewes does not deny the relative smallness of ritual observance, yet he, like Paul, sees the problems with the ceremonial contention if it goes unchecked. He continues, "And to picke a quarrel with a ceremonie, is easie. A plausible theame, not to burthen the Church with ceremonies: the Church to be free: which hath almost freed the Church of all decencie" (9). Andrewes, not speaking "beside the book," repeatedly draws attention to the scriptural basis of his argument by comparing the issues of the English Church to Paul's Corinthians, who debated whether to pray with head coverings (11). Paul also knew and unveiled "Sathans method" over contending with the customs of the church: "[Satan] askes but for some small trifle: Give him but that, he will be ready for greater points. If he win ground in the Ceremonies, then have at the Sacrament: If hee can disgrace the one, it will not be long, but hee shall heare of him at the other" (11). Andrewes lets some anti-Calvinist criticism of idle behavior creep in, that by now must be familiar to the audience at Whitehall: "when they had sit covered at Prayer a while, they grew even as unreverent, as homely with the Sacrament: Eate and drunke there, as if they had beene at home, in triclinio." In line with his November sermon on the beauty of holiness, he continues, "They had homes 
to be homely at: the Church, the House of God, they were to be used with greater reverence," especially at the Sacrament (11-12). ${ }^{79}$ Andrewes's use of ceremony assumes ceremonial observance is no private matter, which connects this concern to the beauty of holiness.

After establishing the importance of properly dismissing contentious trifles, Andrewes shifts from a typical exegesis to a primarily patristic-sourced argument that positions the Church as the authority to settle matters of rite. He begins with biblical precedents, from Christ to Moses, Job, and the prophets before highlighting the Nicene Council, which "let olde customes prevaile" (15-17). The "olde customes" represent the practice of the primitive church, from which the Laudians traced their church's lineage (with other Reformed Christians beginning anew in the sixteenth century). In words endearing to the sermon-sleeper, Andrewes glibly comments at the start of this catalogue - the midpoint of his sermon - "And now I would the houre were to beginne again, so much is to be said for it [his hypothesis that keeping Easter is contentious]" (23). To outline the catalogue briefly, the survey covers 500 years. Andrewes describes it thus: "One foot of our compasse we fixe in the Apostles times. The other where? They appoint us Galasius time, who was fast upon the $500^{\mathrm{dth}}$ yeere" (23). Andrewes's church history has three parts: the apostles' century, followed by 400 years of the church's authority, further split into 200 years of peace and 200 years of persecution. Pope Gelasius's death (496 CE) apparently marks the advent of papal corruption, though Andrewes does not say as much - he might end with Gelasius due to the pope's action on the British islands (see below). For someone charged with over-wringing his biblical texts, Andrewes is terse in his bombardment of scholastic sources, moving quickly from example to example 
without pausing to explicate the patristic texts. Aside from an identification of a heretical sect (the Cathars) as "the Puritanes of the Primitive Church" (26), the argumentative flair is fairly benign, though exhaustive in scope. Andrewes basically explores the early history of Easter (cycli paschales), looking at Paschales epistolae; sermons and homilies from Basil, Nazianzen, Chrysostom, Nyssen, Theophilius Alexandrius, Cyril, and sermons questionably attributed to Ambrose, Augustine (“as Austin”), and Maximus; hymns by Prudentius, Ambrose, Hilarie and Paulinus; commentaries on Easter; and, in conclusion, conciliar evidence from Nicene, Constantine, Ephesus, and Chalcedon. ${ }^{80}$ Andrewes culls widely to support his ceremonial disputation, far outpacing his occasional citation to Augustine or Chrysostom in other sermons.

If this exhaustive catalogue was beginning to bore his auditory (one might hope the catalogue was expanded in revision for publication rather than orated in its entirely), Andrewes, approaching the conclusion, sought to renew interest by including more geographically proximate history, doubtlessly mindful of contemporary controversies. After enumerating broader church councils, Andrewes breaks with chronology to show what the margin calls the "Custome in England," the Council of Arles established Easter through Bishop Restitutus in 314, and the "Custome in Scotland," which is where Gelasius becomes relevant. Andrewes says, "for the other Realm [Scotland] Gelasius shall speak [to a synod of 70 bishops, decreeing them to read] a Poeme of venerable Sedulius (who had the addition of Scotus for his nation) . . . his Opus Paschale ... as it were inviting his Readers (his countrymen, I dare say, specially, if they will come to it) to a Feast, upon Easter day" (37-38). For a usually subdued Andrewes, this is as close as he comes to naming a non-puritan group. ${ }^{81}$ To add to the church-state apparatus, Andrewes 
follows these examples with the "custome in both" being dictated by Constantine's "rescript about Easter, directed to all Churches" that "expresly nameth this Isle, the isle of Britannie, among those places, where this custome was duly and orderly observed" (38). The close proximity of a pope and an emperor, both ordering church custom, surely must have resonated with King James's sympathies. Andrewes's last source is Augustine's Epistle 118, which he cites as an apostolic authority. The citation speaks to the concerns of Perth, as there are multiple feasts to be observed by the whole earth (toto orbe terrarium) each year: "the Passion, the Resurrection, the Ascension of Christ, and the comming of the holy Ghost from heaven" (43, misprinted as "41"). Not uncoincidentally, these are the holidays enforced by the Articles of Perth.

Complaints against feast-day observance are often linked to Sabbatarianism. Andrewes addresses those complaints by resorting to a strategy common in his Easter and Gunpowder Plot sermons - invoking Easter as the model for all feast-days, which includes those Stuart holidays established by James. In the following passage, rife with rhetorical questioning, Andrewes claims that the Sabbath is laid aside the same way that decency and order are during communion:

Now, what a thing it were, that all the Sundayes in the yere that are but abstracts (as it were) of this day (the very day of the Resurrection) that they should be kept: and this day, the day it self, the prototype and archetype of them all, should not be kept, but laide aside quite, and be cleane forgotten. That the day in thet weeke we should keepe; and the day in the moneth it selfe, and returne of the yeere, we should not keepe? Even of very congruitie, it is to be as they, and somewhat more.

Take example by ourselves. For his Majesties deliverance the fift of August: for his Majesties, and ours the fift of November (being Tuesday both) for these a kind of remembrance we keepe, on Tuesday every weeke in the yeere. But when by course of the yeere in their several monethes, the very original dayes themselves come about: shall we not? do we not celebrate them in much more solemn maner? what question is there? weigh them well, you will find the case alike. One cannot be, but the other also must bee Apostolique. (47-48). 
Because Easter is the prototype of all Sundays and holy observations, Andrewes supports his enthymeme of not mentioning the other days (aside from the citation of Augustine) and the Perth controversies through a simple logical deduction: if Easter is valid, then so are all other holy days (this is a notion we will revisit with Herbert in Chapter Four). It seems likely that, in the court, criticism of the Gowrie and Gunpowder Anniversaries would be lessened due to reluctance to criticize the monarch. Given Stewart's insistence that Scottish Presbyterian resistance to the Articles of Perth were at less about theological changes than the source of the changes coming from a king-led episcopacy, Andrewes's focus on the king's deliverance again adds polemical elements to his argument. ${ }^{82}$

$$
* * * *
$$

All three of these sermons respond to the Articles of Perth in formally different, though theologically unified, ways. Andrewes's Gunpowder Plot sermon establishes how often holy service should be performed to God. Buckeridge's Passion Sunday sermon bolsters that by arguing for the importance of kneeling and prostration to be a part of adoration and worship (a union that the text's title minimizes). Andrewes's Easter Sermon, like Buckeridge's, shows the significance of observing ceremonies. All support the power of the state church to create and enforce customs in worship. By having these originate from the pulpit, the arguments are granted a religious ethos not as strongly apparent in prose polemical tracts. At the same time, the stamp of the king's printing house on the title page reinforces the political elements of these worship issues. Those readers seeking a devotional aid can reflect on their use of gesture, while the politically minded can quibble with the officially licensed political theology. 
If a Jacobean turn towards Laudianism truly occurred in 1618, then the polemical import of these sermons may supersede their immediate, exhortatory purposes. If a Jacobean turn towards Laudianism truly occurred in 1618, then the polemical import of these sermons may supersede their immediate, exhortatory purposes. This may be especially true when considering the printed record, as 1618 marks a resurgence in publications concerning kneeling. ${ }^{83}$ After all, Charles and Laud forced their particular brand of worship against a loud puritan outcry. What is to say Charles did not learn that behavior from his father's relationship with his favorite bishop? These sermons clearly respond to anxieties stemming from the Scottish reaction to the Articles of Perth. In appearance and form, they become more polemical, seeking to silence critics from biblical and patristic authority by promoting the church's authority to institute ceremonial custom and worship practices. If 1618 was a moment of political urgency, then a sixmonth evolution in court sermons from exhortatory and didactic towards polemical and disputative makes sense, especially when recorded in print. Yet, at heart, these documents are still sermons - and should be treated as such. Perhaps Andrewes felt this as well, as his next sermon begins with a meta-sermonic commentary that sermons should be driven by a concern to relate the sermon-text to his occasion - an act that recalls his earlier preference to use sermons to preach, not to dispute. ${ }^{84}$

In the next chapter, we shall see a more overtly polemical debate take place. Instead of hiding politics in sermons, we shall see polemical tracts written by William Prynne and Henry Burton decrying the alleged, latent crypto-Catholicism lurking in John Cosin's Collection of Private Devotions, which, like these sermons, was intended for the private edification of its readers. Like Andrewes, Cosin, in private correspondence to 
Laud, expressed a deliberate desire to avoid engaging in the debate, which, for the most part, he did. His scholarly legacy, as a Laudian firebrand, however, does not align with his purported avoidance of polemical diatribes.

${ }^{1}$ Andrewes, Selected Sermons, 88. This sermon was first published in Latin (as it was delivered) in Opscula Quaedam Posthuma (London: 1629), appearing in English as Sacrilege a Snare in 1646. The title of the sermon in the former is Concio ad Clerum Pro Gradu Doctoris, and the quotation, 10, is "Ego concionatum hodie, non disputatum venio."

${ }^{2}$ Mary Morrissey, "Interdisciplinarity and the Study of Early Modern Sermons," The Historical Journal 42:2 (1999): 1111.

${ }^{3}$ This is especially true for those preachers who delivered their sermons extemporaneously or did not write down or publish their sermons at all. For the process of revising sermons for publication, see Arnold Hunt, Art of Hearing: English Preachers and their Audiences, 1590-1640 (Cambridge: Cambridge University Press, 2010), 117-86.

${ }^{4}$ See, for instance, William Gibson, "The British Sermon 1689-1901: Quantities, Performance, and Culture," in The Oxford Handbook of the British Sermon 1689-1901, edited by Keith Francis, et al., (Oxford: Oxford University Press, 2012), 3; David Colclough, ed., The Oxford Edition of the Sermons of John Donne, vol. III (Oxford: Oxford University Press, 2014), xxvi - xxvii; Ferrell 8-10; and Peter McCullough, Sermons at Court, 1559-1625: Religion and Politics in Elizabethan and Jacobean Preaching, (Cambridge: CUP, 1998), 3.

${ }^{5}$ The full citations of these texts are Lancelot Andrewes, A Sermon Preached before His Maiestie, At Whitehall the fift of Nouember last (London, 1617); John Buckeridge, A Sermon Preached before His Maiestie At Whitehall, March 22. 1617. being Passion-Sunday, Touching Prostration, and Kneeling in the worship of God. To which is added a Discourse Concerning Kneeling at the Communion, (London: 1618); and Lancelot Andrewes, A Sermon Preached before his Maiestie at Whitehall, on Easter day last, (London, 1618). In-text quotations of primary texts will be cited parenthetically, throughout.

${ }^{6}$ One of the themes that emerges in this chapter is Andrewes's and Buckeridge's critiques of sermon-centered piety, which Peter McCullough, digital appendix to Sermons at Court, 216-25, has identified as a motif in 1618 court sermons, including those given by John Donne (who Doerksen frames as a "preaching pastor" to juxtapose Andrewes's positioning as "custodian of order"). It is also worth noting that in the decades after these sermons were published, court sermons carry their own baggage being polemically anti-puritan, especially with the rise of antiprelatical tracts. See Prynne's comments in A Briefe Survay and Censure of Mr Cozens his Couzening Devotions, (London: 1628), 78, and quotations in Chapter Two; or the condemnation by John Bastwick, The Answer of John Bastwick (London?: 1637), 12: "Yea in the very CourtSermons they incense the King \& Nobles dayly against those, they brand with the name of Puritans and Sectaries, which all this honorable Assembly can witnes; and the Defendent hath heard many Court-Sermons with his owne eares in the time of his liberty, but never heard one where the Puritans as they terme them, were not brought up in the Pulpit, \& most shamefully \& unchristianly traduced, as those that opposed the Kings proceedings, and such as maligne his government and trouble the peace of Church and State, and humbly besought his Majest. that some severe course might bee sought \& taken against them."

${ }^{7}$ Cognizant of this chapter's title - Andrewes frames the sermon in terms of a disputation, drawing attention to proofs, and seeking to prove his "hypothesis," see especially Sermon ... Easter last, 18-23. 
${ }^{8}$ See, for instance, Doerksen, "The Laudian," 37, and the idea that Laudians "reversed the priorities" by elevating outward order over spiritual life. This misleading stereotype, commonly articulated by literary scholars, may stem from privileging anti-ceremonial polemic over what Laudian preachers actually wrote.

${ }^{9}$ McCullough, "Buckeridge, John," paragraph 5. Elsewhere, McCullough, ed. Selected Sermons, xxix, identifies 1618 as a turning point in Andrewes's career. Contrarily, Alan Cromartie, "King James and the Hampton Court Conference" in James VI and I: Ideas, Authority and Government. Edited by Ralph Houlbrooke, (Farnham: Ashgate, 2006) 80, argues that James shows Laudian tendencies at the start of his reign. The most noticeable omission in this paragraph (and chapters) are references to the Synod of Dort, to which James sent a delegation of Calvinist-leaning ministers to combat the rising "threat" of Arminianism. While some see this as an endorsement of the Calvinist consensus, others dismiss it as a more secular concern with continental politics. Sheila Lambert, "Richard Montagu, Arminianism and Censorship," Past \& Present 124 (1989): 42 and 50-1, suggests that the James had been promoting Calvinist bishops in 1617 but took a Laudian circle with him to Scotland; she also notes that James did not adopt the five resolutions of Dort and suggests countering them with the five Articles of Perth. For my sake, I am more interested in James's domestic policies, which align with McCullough and Cromartie's observations for this point in time.

${ }^{10}$ Peter McCullough, "Andrewes, Lancelot (1555-1626), bishop of Winchester." Oxford Dictionary of National Biography (OUP, January 3, 2008), paragraph 23. Fincham, 244, cites the complaints of "godly protestants" over the Spanish Match that led James to crack down on "tighter controls over preaching," which may have relevance to the anti-sermon piety expressed in these sermons.

${ }^{11}$ For an overview of the Articles and their contentiousness, see Spinks, Sacraments, Ceremonies, and the Stuart Divines, 57-60; Laura Stewart, "'Brothers in Treuth': Propaganda, Public Opinion and the Perth Articles Debate in Scotland," in James VI and I: Government, Authority and Ideas, edited by Ralph Houlbrooke, 151-68, (Farnham: Ashgate, 2006); and Laura Stewart, "The Political Repercussions of the Five Articles of Perth: A Reassessment of James VI and I's Religious Policies in Scotland," The Sixteenth Century Journal 38.4 (2007): 1013-36.

${ }^{12}$ As in Lake, "Lancelot Andrewes," passim, Spinks, The Rise, 38-42, or Fincham, 232-36.

${ }^{13}$ Davies, 60, 245-50.

${ }^{14}$ Comment by McCullough, ed., Selected Sermons, 340, annotating this chapter's title quotation.

${ }^{15}$ As noted by Ferrell, 155-56 and 163-64, James paraphrases these sermons' anti-Puritan rhetoric his 1619 and 1620 Meditations on the Lord's Prayer and Matthew. Doerksen, Conforming to the Word, 94-95, cites Andrewes's 1618 Whitsunday sermon (referenced later in this chapter) to argue that it is just as likely that Andrewes targets James court in general as opposed to puritans, writ large.

${ }^{16}$ Such a use of a textual headnote seems uncommon, with only four of the sermons in XCVI Sermons containing such a comment. Three of those four denote the sermon-texts (all non-feastdays) correspond to the $B C P$ 's calendar of readings. A fourth contextualizes a 1592 sermon on the Ten Commandments with others on the "positive outward worship of God." For the other four sermons, see XCVI Sermons, 299, 1049, 1143, and 1025.

${ }^{17}$ For the Gunpowder context, see McCullough, ed., Selected Sermons, xxv-xxvii and 390-91. ${ }^{18}$ XCVI Sermons, 890.

${ }^{19}$ Andrewes's 1617 is the fourth consecutive Gunpowder sermon to reference the Armada, but it also the last reference to the occasion in his corpus. See McCullough, Sermons at Court, 123-25 for Andrewes and Jesuits in Gunpowder sermons.

${ }^{20} \mathrm{He}$ does make one reference to making the occasion a holy day, 1-2: "For I demand: Delivered we were (as this day) why was it? ... Was it, that wee might blesse our selves . . . or bestow a piece of an Holy day on God, for it? And al these we may do, and All these we have done; and upon good ground, all." 
${ }^{21}$ For Andrewes on the plot as a second resurrection, see his 1605 Christmas and 1606 Easter sermons, XCVI Sermons, 6 and 391. For November 5 as Purim, see his 1606 and 1618 Gunpowder sermons, 890 and 997-1008.

${ }^{22} \mathrm{Cf}$. his 1614 Easter Sermon on kneeling at the name of Jesus that seemingly lacks an individual or political impetus.

${ }^{23}$ Unlike in other rhetorical modes and elsewhere in XCVI Sermons, Andrewes does not draw attention to his lack of translation. Alison Knight, "The Odious Original Andrewes and Scriptural Indecorum," in a paper presented at the Lancelot Andrewes and Early Modern Religious Culture Conference, March 26, 2021, drew attention to Andrewes's "veiling" of the text, often in regards to Isaiah 64:6, in which he would say for example in his 1615 Whitsunday Sermon, XCVI Sermons, 676, "the Prophet resembles it so homely a thing, as I list not tell you; what it is: but it is pannus menstruatus, english it who will." Peter McCullough commented by drawing attention to his rhetorical ploy, Andrewes was in fact unveiling the text for the readers, make them do the work and focus on his message.

${ }^{24}$ Ryrie, Being Protestant, 171-73.

${ }^{25} 1604 B C P$, sig. N[1]r. The first quotation is a general confession; the second is directed to "them that come to receive the holy Communion." Both the prayer and the following instructions dictate "all kneeling humbly upon their knees." The instructions for distribution, N3r, instruct the people to kneel. Though these quotations are from the 1604 BCP, they are identical to the precepts laid out in the 1559 revision (but not the 1549).

${ }^{26}$ Cf. Robert Shelford, Five Pious and Learned Discourses (Cambridge, 1635), who juxtaposes sermon-centered piety (as an afront to) with the beauty of holiness. In "A Sermon Shewing How we ought to behave ourselves in Gods house" (sermon-text Psalm 93:6 - "Holinesse becometh thy house, O Lord, for ever), the Suffolk priest, 11-13, says "One beauty hath beat out another; the beauty of preaching (which is a beauty too) hath preacht away the beauty of holinesse." Shelford takes a moderate approach, not diminishing sermons, but admonishing his audience to take care to adorn the church as the Bible suggests. Apropos to Herbert's "Church-Porch," Shelford's "second office of holinessse, is a holy preparation before we enter Gods house." In Shelford's $O D N B$ the biographer, para. 3, writes this publication made his "Laudian sympathies very clear." Arnold Hunt, "Shelford, Robert (c. 1563-1638/9), Church of England clergyman and religious writer," Oxford Dictionary of National Biography, (OUP: September 23, 2004); (accessed Sep. 9, 2020).

${ }^{27}$ Though, as with de geniculus a few pages later, it is possible Andrewes meant for his reader and auditor to focus on the décor, but his explicit focus is on the lack of grave behavior. As mentioned in the Introduction, when it comes to church policy, it is important to distinguish Andrewes's private practice against his preaching. To support his thesis of showing that Laud was not the political mastermind behind Laudianism, Davies, 209-10 and 250, suggests that it is Andrewes's private practice that serves as the basis for the 1630s "Beauty of Holiness" requirements for the altar rail and organization. He conjectures James asked Andrewes to replicate his private chapel adornments in the Chapel Royal and that Wren had more a part of expanding that practice widespread than Laud.

${ }^{28}$ The sermon margin cites 1 Corinthians 12:17 (KJV: "If the whole body were an eye, where were the hearing? If the whole were hearing, where were the smelling?"); Romans 12:1 ("present your bodies a living sacrifice ... which is your reasonable service") also seems relevant, as it was for Hooker's ceremonialism, Lawes, V.IV.4.v.27. This is right after Andrewes's sarcastic remarks about sermon-going: "For, what is it to serve God in holiness? why, to go to a Sermon: All our holiday holinesse, yea, and our working day too, both are come to this, to heare (nay, I dare not say that, I cannot prove it) but, to be at a Sermon." For sermon-centered piety as Calvinist and the practice of sermon-gadding, see Hunt, Art of Hearing, 22ff. and 60-117.

${ }^{29}$ Andrewes compares sermon-going to hearing ballads sung. He also discerns that "Eye-service God likes not" no more than eare-service. Again, Andrewes acknowledges that hypocrisy can 
stem from gesture (the eye-service) done without the whole body - without the meaningful inner piety that marks holy worship. Compare 44-45, where service is done coram ipso in "the terme for the Law. As if He were present and looked on. And it helps much to our service ... Helps our reverence, not to doe it rudely: (we doe it before Him.). Helps our sincerenesse, without hypocrisie to doe it, as before Him: For these two words, coram ipso, are the bane of hypocrisie." ${ }^{30}$ In context, Andrewes moves to righteousness, but the complaint is lodged against those who frequently attend lectures, without actually doing any devotional acts.

${ }^{31}$ This debate plays out in other genres, such as in Buckeridge's prose discourse and, interestingly, as we will see in Chapters Two and Three, private devotions. Compare Daniel Featley's Ancilla Pietatis, or, The Hand-Maid to Private Devotion, (London: 1626) that focuses on private devotion to John Cosin's A Collection of Private Devotions or The Houres of prayer, (London: 1627), esp. sig. A8v, which is a Book of Hours that essentially makes private what the BCP makes public. Thomas Tymme in his Chariot of Devotion (London: 1618) applies this debate to prayer and, for a Suffolk minister, echoes the court preachers extensively.

${ }^{32}$ Considering his inclusion of common prayer in the list, he also says, 39, that "common and holy are contradividentia." However, this is in the context of not magnifying God's name above all others, to use it irreverently. Here, to make common means to make base - if people were inattentively reciting the liturgy (a not uncommon complaint), then it would be common in this sense, rather than in a communal one.

${ }^{33}$ Andrewes's own practice is relevant. See, for instance, Buckeridge's claim that Andrewes daily spent five hours in prayer in Andrewes's funeral sermon, XCVI Sermons, 22. This repeated in Andrewes's posthumous The Private Devotions of Andrewes, (London: 1647), sig. A2. Notably the first prayer in that collection is At your entrance into the Church before publique service. The translator (Andrewes's Preces were written in Greek) takes less care than Andrewes in using precise, non-idolatrous language (cf. Buckeridge's altar talk below). He writes, sig. B1r, "I will worship towards thy holy Temple in the reverence of thee. . . when I lift up my hands towards thy Sanctuary" (my emphasis). While this prayer is directed to God, the nuance of directing worship and gesture to God is muddled. Comparable to the devotions in chapter three, Andrewes, sig. B1r-v, also prays "my brethren also which stand about me and pray together with me" in an attempt to emphasize the union in common prayer.

${ }^{34}$ The phrase "beauty of holiness" at least dates to Coverdale's 1535 translation. Hooker, Lawes, V.XVI.2.58.

35 This reiterates the earlier theme, 10, that service is a reciprocal duty of the covenant of salvation: "Liberati, you see, precedes serviamus ... And the reason, why He will have it so to praecede, is, He would have our service grow out of His favours, our duety, out of His bounty. That, is the right, and, (indeed) the Evangellical service."

${ }^{36}$ Fincham, 239, notes that it was in 1617 as Dean of Gloucester that Laud first ordered the communion table to be oriented eastward, following the example of the Chapel Royal. He also cites, 281, this passage of Andrewes only to emphasize the "Arminian vision of decorous worship" that was outlined in it, saying that "[h]is episcopal chapel best expresses Andrewes's notion of the "beauty of holiness"" in its decoration and monthly communion observances.

Fincham disregards Andrewes's emphasis on behavior.

37 "Mock-service" is p. 45. Hypocrisy and gesture feature prominently in Chapter Three.

${ }^{38}$ This also culminates his point, 28, that "Holinesse is one thing: To serve God in Holinesse, is another," where the former may be a "stately, surly kinde" that lacks service.

${ }^{39}$ There is perhaps an oblique reference to communion, in that Andrewes ends the sermon, 49, by returning "to the word of our service" that is the result of the covenant, but he makes no allusion to the covenant of Christ's body. The marginalia, however, says "Reward is in the body of the word" to serve. 
${ }^{40}$ Transliterations from Strong's Bible Concordance at BibleHub and StudyBible. latreuo https://biblehub.com/greek/3000.htm; abiydah https://studybible.info/strongs/H5673; leitourgia https://biblehub.com/greek/3009.htm.

${ }^{41}$ This quotation echoes his earlier complaint, 30, about people ignoring the Venite, when churchgoers "come and go without it [reverent service], Nay they scarse know, what it is." We will see Thomas Tymme reiterate this complaint in Chapter Three.

${ }^{42}$ See, inter alia, McCullough, Sermons at Court, 122-23, or his "Absent Presence: Lancelot Andrewes and 1662," In Comfortable Words: Polity, Piety, and the Book of Common Prayer, ed. by Stephen Platten and Christopher Wood, 49-68, (London: SCM Press, 2012), 49-68, esp. 60.

${ }^{43}$ David Calderwood, Perth Assembly (Leiden: 1619), 38, 48, 51, 57, 58, 61. Essentially, Calderwood disagrees with Buckeridge over the various interpretations of "standing."

${ }^{44}$ See, for instance, Spinks, The Rise, 55.

${ }^{45}$ According to McCullough's "Calendar of Sermons Preached at Court" (the digital appendix to Sermons at Court), Buckeridge regularly preached at court during Lent - though this is his last recorded appearance. Only three of his sermons survive: his 1606 Hampton Court Sermon, this sermon, and Andrewes's funeral sermon in XCVI Sermons. The first two carry charges of plagiarism: see respectively P.J. Klemp, "Lancelot Andrewes, Plagiarism, and Pedagogy at Hampton Court in 1606," Philological Quarterly, 77.1 (1998): 15-33, and McCullough, "Calendar," 219. However, although McCullough says Buckeridge plagiarizes Andrewes's 1617 Gunpowder Sermon, there are stronger verbal similarities to Andrewes's 1614 Easter Sermon on kneeling.

${ }^{46}$ Passion Sunday is two weeks prior to Easter, so with Easter 1618 falling on 5 April, Passion Sunday would be 22 March.

${ }^{47}$ The verse is printed three times in the headnote, in English as appears above, and twice in Latin, with the Vulgate's ploremus [let us weep] followed by the Septuagint's genuflectamus [let us kneel]. The difference for Buckeridge is largely inconsequential as both kneeling and weeping are signs of contrition. Buckeridge comments on the distinction between kneeling and weeping, 2 and $20-21$.

${ }^{48}$ Cf. Andrewes's Sermon . . November Last, 30: "we are told every day in the Psalme" to observe the Venite.

${ }^{49}$ The occasion is fairly obscure in England, with the English Short Title Catalogue listing only two other pre-Restoration sermons on the occasion, published in 1612 (Richard Sheldon at St. Martins-in-the-Field) and 1616 (Sampson Price at Paul's Cross). John Rastell's confutation of Jewel's Challenge Sermon associates Passion Sunday with Catholicism: A confutation of a sermon, pronounced by M. Iuell, at Paules Crosse, the second Sondaie before Easier (which Catholikes do call Passion Sondaie, (Antwerp: 1564). http://estc.bl.uk/ (accessed February 5, 2021). Though Buckeridge does not preach fasting in this sermon, it is common to group festival days with fasting days (the latter most commonly occurring during Lent): see Featley's defenses in Chapter Two below, or Hooker V.LXXII.1.407: "Having therefore spoken thus much of festival days, the next that offer themselves to hand are the days of pensive humiliation and sorrow."

${ }^{50}$ For contemporary attacks on kneeling as outward and superstitious, see Calderwood, sig. A3r and 53, or Thomas Dighton, Certain Reasons of a Private Christian Against Conformitie to kneeling in the very act of receiving the Lords Supper (Leiden: 1618), 2. Writing on the other side is Thomas Morton, whom Guibbory, Ceremony 20, cites and identifies as "a Calvinist, [who] was doctrinally far removed from Arminian Laudians." He wrote, 167, that inward devotion vanishes without outward worship. The three ceremonies are the surplice, crossing at baptism, and kneeling at the sacrament. Fincham, 227, records that Morton was forced into writing this pamphlet "to regain royal favour," though he had, as Bishop of Chester, forced ministers into subscribing to the canons. Later, 259-60, he says Morton's "motives in printing the work were not pastoral . . . rather, the Bishop was intent on protecting his career." 
${ }^{51}$ Lake, "Lancelot Andrewes," discusses kneeling, 128-130. However, he says, 128, that "Buckeridge claimed that outward bodily reverence ... helped to form or create internal spiritual reverence." Buckeridge, like Andrewes, would argue that the two go together (as he glosses with Andrewes, 129), but it begins with the inward. Cf. his "Laudian Style," 161-85, focused on the altar policy, Sabbatarianism, and the "beauty of holiness" with no mention of internal piety whatsoever. Fincham, 235, summarizes their viewpoints similarly to Lake, with privileging the outward over or before the inward: "Both Andrewes and Buckeridge argued that we must worship God with both body and soul, and from outward gestures of kneeling our minds can learn the service and obedience appropriate to God."

${ }^{52}$ In arguing for decency, Andrewes's ceremonial lineage at least goes back to Cranmer's $B C P$ essay "Of Ceremonies." For other references to decency in Andrewes, see his 1614 Easter Sermon on kneeling at the name of Jesus, XCVI Sermons, 477, his 1618 Easter sermon (A Sermon ... Easter last, 8, 20-21 or XCVI 519, 522), or his 1592 sermon on the second commandment, XCVI Sermons 1030. Decency and order - from 1 Corinthians 14:40 - feature prominently in Andrewes, Hooker, and Herbert, as we will see in Chapter Four.

${ }^{53}$ The reference to Romans 12:1 (that core verse of Hooker, see note 27 above) is not marked by the preacher or the textual apparatus.

${ }^{54}$ See also 11: "And likewise the place, for it is not Praeveniamus ipsum, Let us come before him, for that may be done in every place; on the way, in the field, in the chamber, in the bed, in the closet, and every where, when wee are most retired and alone; but it is Praeveniamus faciem eius, Let us come before his face, or his presence, with thankesgiving. His presence is his Tabernacle, or his Temple, the place which hee hath chosen to dwell in; And then, as the adoration is compleat and solemne, so it must have all the parts, and dueties thereof performed to God" and 26: "And externall sacrifice is due onely to God, because it is a signe or testificatio[n] of the inward sacrifice of the heart, in which none hath any part but God onely."

${ }^{55}$ See also 12: "First, internall Adoration, that is, the devotion of the heart, and inward worship: and next outward worship, that is, Prostration, falling downe, or bending of the body, and kneeling, which is a kinde of falling downe, and may well be included in it. In all adoration, the inward devotion and sacrifice of the heart in prayer, and praise, is alwayes required and accepted."

${ }^{56}$ For other repetitions of the inner-outer dimensions of worship, see 3, 12, 17-18. That this worship is tendered to God alone, see 23-26.

${ }^{57}$ For the contention, see, Ferrell, 149-67; Stewart, "Brothers," 151-68; or Ryrie, Being Protestant, 171-3.

${ }^{58}$ Compare Andrewes, XCVI Sermons, 475-6: "They in the Primitive Church, did so, did bow. And verily, He will not have us worship Him like Elephants, as if we had no joynts in our knees." 59 "The Church-Porch," lines 407-08. Wilcox annotates, 81: "Humility in church is appropriate even for those of elevated social status." The surrounding stanzas of the poem speak directly to the value of public and private prayer, and the value of sermons and prayer.

${ }^{60}$ See also 24-5, where Buckeridge argues that the duty for "Naturall, Morall, and Civill reverence or adoration" is also due to earthly kings, priests, and parents. "And this duetie is derived fro[m] Religion \& the worship of God, \& is done only for Gods cause; yet it is not properly religious in the strict sense, but Civill and humane: For mans Lordship and dominion is not absolute and supreme in respect of Gods, but under God, and limited and coarcted by his Law." Buckeridge excludes angels and saints from divine worship.

${ }^{61}$ Ferrell, 160, cites this passage an example of the king's will dictating the Church's practice. ${ }^{62}$ Robert Wilkinson, Barwick Bridge: or England and Scotland coupled. In a sermon tending to peace and unitie, (London: 1617), 25-26.

${ }^{63}$ Daniel Doerksen, "Preaching Pastor Versus Custodian of Order: Donne, Andrewes, and the Jacobean Church," Philological Quarterly 73.4 (1994): 422-23. Doerksen perhaps 
overemphasizes Andrewes's attachment to the beauty of holiness and cites it in a way that is to be seen as less compatible with sermons.

${ }^{64} \mathrm{~A}$ full explication of these issues is beyond the scope of this dissertation, as I forwent a chapter on catechisms, outside of Featley's catechism attached to Ancilla Pietatis (in Chapter Two). The debate over the Book of Sports (also published in 1618) and puritan responses to Cosin's A Collection of Private Devotions shows other complaints about Sabbatarianism. Paula McQuade's work on Dorothy Burch has shown catechisms to enter Puritan-Laudian and confessional debates, Catechisms and Women's Writing in Seventeenth-Century England, (Cambridge University Press, 2017), 89-138.

${ }^{65}$ The call to look on the cross, though, may be closer to Lutheran, rather than Catholic, Christology. See McCullough, "Lancelot Andrewes's Transforming Passions," passim. ${ }^{66}$ Ryrie, Being Protestant 289-90.

${ }^{67}$ Lawes, V.LXVIII.3.366. It is also worth noting that the idea that Christ kneeled at Gethsemane, preached by Buckeridge, 12-13 and below, is an echo of Lawes V.LXVII.13.362. Furthermore, V.LXVI.9.348 cites Ephesians 3:14 to support that kneeling is a means of obtaining grace. ${ }^{68}$ McCullough, "Buckeridge, John," para. 5, briefly refers to this passage showing the bishop to be "bolder" than Andrewes for his radical insistence on kneeling-as-duty.

${ }^{69}$ The partial refutation comes at 241-43: while for Buckeridge "it is a duety," he says he "will not be contentious" against those who argue against kneeling as adiaphora.

${ }^{70}$ Unlike the allusions to patristics in Andrewes's Gunpowder Plot sermon, Buckeridge's references venture away from biblical commentaries and into doctrinal positions.

${ }^{71}$ The citation of Calvin perhaps exemplifies the evolution of English Calvinism in later generations (i.e., after the 1540s) beyond Calvin's own views. See for example Green, The Christian's $A B C, 347$.

${ }^{72}$ Buckeridge does not name the source. Earlier in the work, 44, he says he is answering Sparke, Covell, Hutton, and Rogers, who all published independently against kneeling. The first three are named in the title page of the Defence of the Ministers Reasons, for the Refusal of Subscription to the $\mathrm{BCP}$ and of Conformitie (1605). This might suggest the 1605 Lincoln Abridgment (published in 1606 and reprinted in 1617), but the page numbers and arguments Buckeridge cites do not match any of the above.

${ }^{73}$ He also repeats that the king is keeper of law, 245-46.

${ }^{74}$ Stewart, "Brothers in Treuth," 155. Her "Political Repercussions," passim, argues that kneeling at communion was the chief offendiculum of the articles, though the holy day observance was second. She is clear that it is the entire cycle of holy days, not just Easter and Christmas.

${ }^{75}$ This non-liturgical text is made especially ironic considering McCullough's assessment, "Making Dead Men Speak," 411, that Andrewes's 1618 Whitsunday sermon - his next delivered sermon after this Easter sermon - mandates that "sermons should always expound texts fit for the liturgical season or holiday. He cites XCVI 710, 720.

${ }^{76}$ This verse also appears on the title-page to Morton's 1618 A Defence.

${ }^{77}$ Coincidentally, Buckeridge's choice of Psalm 95:6 also goes against the $B C P$ 's chosen readings for Passion Sunday. With the talk of contentions and ceremonies, it may be relevant to cite Herbert's A Priest to the Temple, or, The Countrey Parson (London: 1652), 92-93:

"Contentiousnesse in a feast of Charity is more scandall than any posture."

${ }^{78}$ Sermon . . Easter, 24: "As God would have it, the question never was of the Feast it selfe, but of the time of it onely."

${ }^{79}$ 13-14 reiterates the distinction: "And feare not traditions a whit. Those respect credenda, points of doctrine: These, but agenda, matter of practice: and that, not in points of substance; reach onely to matter of circumstance, goe no further."

${ }^{80}$ Andrewes summarizes, 37, "all these wayes, by singing, by saying, by writing, by doing, all beare witnesse ... and among them they make up a full proofe, of this habemus consuetudinem" 
[we have a custom]. The cycli paschales and paschales epistolae are 28-30, sermons 31, hymnes 32, commentaries 33, 35-37 moves to the councils and into England.

${ }^{81}$ See, inter alia, Ferrell, 160, for Andrewes's politic behavior that avoids controversy.

${ }^{82}$ Stewart, "The Political Repercussions," 1013-14.

${ }^{83}$ According to the ESTC, using the search query "kneel*" brings up 21 results between 1600 and 1626: five from 1604-1610, three in 1618, seven in 1619, and six between 1620-1626. Notably, after 1618, all anti-kneeling tracts were published outside of London.

${ }^{84}$ See note 75 above. 
Chapter Two: Merely Popish? John Cosin and his "barking Libellers"

Like many of their sixteenth-century forebears, English devotional writers in the 1620s were conscious that there were more Catholic devotional books than Protestant. ${ }^{1}$ In this chapter I turn to two mid-decade devotionals that variously sought to redress that gap. In 1626 Daniel Featley first published his Ancilla Pietatis (The Handmaid to Devotion), which set out to offer an English devotional text to lessen the influence of Catholic models of piety. One year later, John Cosin's A Collection of Private Devotions also appeared, but instead of marketing a decidedly anti-Catholic book, Cosin sought to show the ways the Church of England appropriated "All the Ancient Formes of Piety and Devotion," which had the effect of highlighting Catholic continuities (sig. A8v-9r). Both works met with success: between 1626 and 1676 Featley's text went through nine editions and Cosin's twelve. However, while both works advocated conforming to the established practice of the Church, only Cosin's received severe puritan backlash. Two 1628 polemics, William Prynne's A Briefe Survay and Censure of Mr Cozens his Couzening Devotions and Henry Burton's A Tryall of Private Devotions, lambasted Cosin for reintroducing popery to an English audience. Although Featley supplemented his second edition (published before Cosin's first) with patristic defenses on the church's fasts and feats (sig. a6v), there is no printed record attacking his ceremonial conformity. I argue that Cosin and Featley both work to advance two very different types of Laudian conformity, with Cosin advancing a traditional - but Protestant - approach to worship, while Featley, not conventionally considered Laudian, defends the church's right to establish ceremonial practices. ${ }^{2}$ The lasting influence of the puritan polemical responses to the former has challenged scholarly understandings of Cosin's Laudianism, in which 
the failure to distinguish it from crypto-Catholicism has made Cosin appear more extremist than his writings reflect.

One way to reassess Cosin's theological positioning is through genre. The previous chapter focused on two ways to read printed sermons: as admonitory orations and polemically. Similarly, as the devotional genre lends itself to didactic self-instruction on ways to better one's personal worship habits, one would expect devotions to be an educational genre that largely ignores polemical concerns. Such is the claim of Ian Green, who argues that the genre's focus on explaining basic tenets of religion largely precludes participating in confessional debates. ${ }^{3}$ While the next chapter operates against that claim on a broader level, this chapter zooms in on one of the most well-known confessional debates that stemmed from the publication of a single devotional. The irony of this claim is that the puritan polemic seems to target the circumstances of the publication and the infamous antics of the author more than the work itself: Cosin's text provides traditional devotional material without singling out anyone who needs to reform their actions (excepting his list of "offenders" of the Ten Commandments). The problem for readers in the twenty-first century is that the puritan glosses of crypto-Catholicism have become so entrenched that one commonly approaches Cosin with a distorted understanding of Laudianism that assumes Cosin and his work are indelibly anti-Calvinist and staunchly Catholic, despite the moderate and distinctly Protestant elements found in Cosin's prayerbook.

Given the origin story of the Collection of Private Devotions, it is easy to see how puritan partisanship exaggerated Cosin's irenic rapprochement to Catholicism into cries of crypto-Catholicism, most of which stems from a disagreement over tradition. At the 
onset of Charles's reign, one of the common complaints about English devotional literature was the lack of non-Catholic private devotional material. While Protestants made do with Catholic models, many were left wanting their own. ${ }^{4}$ Daniel Featley's dedicatory Letter to the Reader in Ancilla Pietatis (1625-26) argues that while in "Treatises of Devotion" the "Romanists for the most part exceed in bulke, but our Divines in weight," Catholic devotions "are bleare-eyed with superstitio[n]" (sig. A6r). Thus, he employs a markedly anti-Catholic purpose in crafting his devotion manual. As we will see in the last parts of this chapter, Featley mostly avoided any serious criticism of his work. At Charles's court, however, there was the slight problem, for a Protestant nation, of individuals publicly converting to Catholicism, no doubt due in part to the influence of the queen, Henrietta Maria. According to the accounts by John Evelyn and Peter Heylyn (noted diarist and Laud's biographer, respectively), John Cosin wrote and published the Collection of Private Devotions in 1627 for the ladies at Charles I's court so they could have a Protestant model of devotions to rival the displays of piety from the Catholic ladies-in-waiting. ${ }^{5}$ Though the devotional eventually found a wider, more public audience, its (alleged) initial audience certainly added fuel to the puritan outcry of popery.

Of all the authors in this project, John Cosin is the most prototypically Laudian in its political sense. While much of Laudianism's ceremonial theology and practice stems from Andrewes and Hooker, it is Cosin who, as Bishop of Durham (consecrated 1660), cemented the liturgical practices in the 1662 Anglican revision of the $B C P$. However, Cosin's prototypical Laudian portrait stems not from his encyclopedic knowledge of ceremony and liturgy. It comes from his enforcement of ceremonial behavior. As made 
clear from the articles charged against "Doctor Cozens," it was not that Cosin moved the altar location, bowed during communion, or "converted divers prayers in the book of Common prayers into Hymnes" but "That he compelled others to doe it, using violence to the persons of them that refused so to doe: for instance, once some omitting it, he comes out of his Seat, down the Seat where they sate, being Gentlewomen, called them Whores and Jades, and Pagans, and the like unseemly words, and rent some of their Clothes." Assuming that these allegations are true, Cosin, as Dean of Durham, acted in a manner apropos the stereotypical description of political Laudianism with its rigid enforcement of conformity. It is fitting, then, that Charles's disbanding of Parliament and the start of the Personal Rule saved Cosin from Parliamentary censure. ${ }^{7}$ Cosin's celebrity, rather than his writing, made him a prime target for puritan polemic, which is why more scholars call him a "Laudian pointman," "Laudian stormy petrel," or even "semi-Catholic" instead of aligning with his twentieth-century editor who acknowledged Cosin was "a good deal more moderate than the clamor of his puritan opponents" claimed. ${ }^{8}$

Because Cosin plays a key role in the evolution of Laudianism (and, after 1660, Anglicanism), understanding his actual positions helps demystify the Laudian-Puritan binary. Against the overstated accusations of crypto-Catholicism, I argue that even the cantankerous Cosin sought an inclusive theology reliant on ritualistic observance of ceremony. ${ }^{9}$ Much like Julian Davies did by revealing Prynne's sleight-of-hand in misrepresenting Laud in Canterburies Doome (1645), I seek to unravel some of the more tenuous arguments of Prynne and Burton to reveal their misreading. ${ }^{10}$ While the puritans in their unlicensed tracts had a more legitimate argument about censorship and licensing by the London presses (in which Laud, as Bishop of London, played a not insignificant 
role after 1628) and rightly identified the quotation of a Jesuit prayer in one of the set prayers, the less legitimate accusations of crypto-Catholicism often fall short of the mark, relying on circular reasoning or intentional distortions of Cosin's words. In this sense, the vituperative prose undermines the disagreement over ceremonial observance because the authors would rather castigate the alleged popery as idolatry than faithfully investigate the difference in interpretation and practice. Cosin, on the other hand, was happy to let his opponents prattle in public fora while remaining silent himself. In a letter to Laud, Cosin dismissed the "licentious libels" (later, "barking libellers") that "doe not affect me." He continued, "I have resolv'd to make no other answer then Dixi, Custodiam, and to make no other revenge upon such intemperate malice then contempt and silence doth upon a scolding and unbridled tongue." ${ }^{11}$ Cosin is in the opposite situation of Andrewes and Buckeridge, who, as seen in Chapter One, were responding to a political impetus by keeping the debate muted in their sermons. By failing to address it publicly, Cosin let the puritans have the last word, which seemingly enhanced their argument. The effect echoes to this day: scholars can only rarely mention the Private Devotions without a reference to Prynne and, occasionally, Burton. This not only allows the puritan agenda to overpower and misrepresent Cosin's agenda but also suggests that Cosin's text cannot stand by itself, even though it went through several more editions than the dissenting tracts. 


\section{The Texts of Cosin, Prynne, and Burton}

In what follows, I give space to all three texts in an attempt to recognize them on their own accord while also showing the flawed methodology of the puritan misreading that deliberately distorts or ignores what Cosin actually wrote. That is, I want to show the merits of Prynne's and Burton's critiques while at the same time recognizing that they are "hardly representative puritans" who look "neither closely nor fairly" to Cosin's text. ${ }^{12}$ Indeed, few scholars look deeply at Prynne or Burton's work (Alec Ryrie may be the only recent scholar to have actually read Burton's work, whereas most refer to it passingly). For examples of this tendency, see Stanwood's description of Prynne's work as “extremely laborious, without a trace of humour, loaded with learned but often irrelevant notes" and filled with "many extremely trivial and doctrinally indifferent points" or the muted snark of the Bodleian librarian who, in commenting on Prynne's assessment of the press, simply wrote "Here there is no reason to doubt Prynne's statement."13 At the same time, I want to emphasize Cosin's Laudian gloss on his source material, most evident in his commentary on the didactic elements preceding the daily offices.

More so than anything else, Cosin's Private Devotions is a book of carrying out traditions. As regards the Laudian-crypto-Catholic debate, the question becomes "which tradition?". For Laudians, in reforming from Catholicism, the Reformed Church both recognizes the error of papal corruption and claims to be the heir of the primitive or universal church. ${ }^{14}$ Prynne and Burton align more closely with those that argue Protestantism reformed against Catholicism, almost as if the church began anew in the sixteenth century and that the English Church needs no continental influence. ${ }^{15}$ Thus, for the more puritanical, aside from Scripture, only a few traditional sources avoid the label 
of popery, which is why Cosin's text becomes a prominent target for accusations of crypto-Catholicism. Cosin's full title of his devotion shows four non-Catholic precedents: Elizabethan religious literature, Scripture, patristics, and the BCP: A Collection of Private Devotions: In the Practise of the Ancient Church, called the Houres of Prayer. As they were after this manner published by Authoritie of Q[ueen] Eliz[abeth]. 1560. Taken Out of the Holy Scriptures, the Ancient Fathers, and the divine Service of our own Church. While the title calls attention to the Hours of Prayer (the Divine Offices) as they appeared in the 1560 Horarium Regia, Cosin's text is essentially a primer, a genre that had its apogee in the mid-Tudor period but, ironically (for prayerbook conformists) fell out of favor with the printing of the $B C P .{ }^{16}$ Outside of the Elizabethan precedent, Cosin's methodology is essentially that of the "Patristic Reformed Churchmen" - he begins each Office with scriptural references to praying at that hour and then supports them with patristic references before reprinting or expanding the liturgy as found in either the $B C P$ or Horarium. ${ }^{17}$ While the Book of Hours is the core of the devotional, the work contains several other didactic materials common to the genre, such a feast-day calendar, expositions on the creed, Lord's Prayer, and the Ten Commandments, along with the Penitential Psalms, Litany, and other occasional prayers, including for the dead and the monarch. ${ }^{18}$ As a whole, Cosin's Private Devotions is a book for all occasions.

With his emphasis on true church tradition, Cosin maintains the Laudian party line of the Church of England being the true descendent of the Ancient or Primitive Church, the tradition of which erred with the dawn of papal corruption. This belief manifests itself in Cosin's four-fold purpose for creating this work, which seeks to make private what the $B C P$ had made public. In the preface, Cosin outlines that his purposes in 
writing were to 1) "continue \& preserve the authority of the ancient Lawes, and old godly Canons of the church" in observing prayer rituals; 2) show that the Church of England has not abandoned the old faith with its ceremonies and sacraments (a contentious point, depending on when the "old faith" is dated); 3) give those unable to attend public services a method to practice devotions in private; and 4) stir others up by offering pious examples (sig. A5r, A7r-9r). As mentioned in the Introduction, the Church of England's use of ceremony sought decency and order and tried to draw a line between scriptural adherence and man-made superstition. In line with staunch defenders of the Reformed tradition, Prynne's contention is that ceremonial tradition is inherently popish: while he does the bibliographic work to show that some of Cosin's sources were Elizabethan, he argues "all of them [are] exactly framed, after the Popish Offices, Primers, and Horaries, and not according to our Common Prayer Booke, or any Protestants Method" and that "hours of Prayer" is a "Romish" phrase (5-8). Prynne discounts the practice of the Lutheran churches, which observed several of the canonical hours, and ignores that Elizabethan primers had eliminated or omitted from their texts the more overtly Catholic practices like the Ave Maria. He likewise discounts the appearance of the Offices in the BCP's Morning and Evening Prayer services and the liturgical settings found in the popular BCP alternative, Sternhold and Hopkins's metrical Psalter.

William Prynne's response to Cosin has two main ends: to attack Cosin's brand of religion and to criticize the press's selective licensing of texts. The text's full title summarizes his argument: A Briefe Survay and Censure of $M^{r}$ Cozens His Couzening Devotions. Proving both the forme and matter of $M^{r}$ Cozens his Booke of Private Devotions, or the Houres of Prayer, lately published, to be merely Popish: [sic] todiffer 
from the private Prayers Authorized by Queene Elizabeth 1560. to be transcribed out of Popish Authors, with which they here paralelled: and to be scandalous and prejudiciall to our Church, and advantagious onely to the Church of Rome. The charge of popery is Prynne's predominant motif, though he is lax in defining the term. The tract's title page has two scriptural epigraphs, Matthew 7:15-16, "Beware false prophets which come to you in Sheepes clothing ... Ye shall know them by their fruits," and 2 Corinthians 11:1415, "For Satan himselfe is transformed into an Angell of light. Therefore it is no great thing if his Ministers also be transformed as the Ministers of righteousnesse, whose end shall be according to their workes." Together these verses show Prynne's polemical aim to be quite clear: Cosin's devotional brand has only a deceptive Protestant veneer and is not spiritually edifying. Though Cosin's text is full of prayers, Prynne argues that their origins preclude Protestant value. The pamphlet itself has two parts: the lengthy censure and survey of Cosin's work and a dedicatory epistle that is addressed to the House of Commons and not the House of Lords, presumably a political gesture against the episcopacy and crown.

Usually mentioned as a footnote to Prynne's polemic, Henry Burton's A Tryall of Devotions. Or a Diall for the Houres of Prayer is formally more complex than Prynne's tract. The book portends to be a dialogue between two courtly ladies, perhaps picking up on Cosin's intended audience. Curia, a housewife, has given Cosin's book to Charis, who lives in the country; Charis feels the book is papist and invites a minster to read it, whose reading appears after a second title page. A third title page repeats the title of the Trial of Devotions, showing it to respond to Cosin. At this point, the book drops the façade of a dialogue and engages in typical polemical critique. Toward the end of his work, Burton 
moves from Cosin to attack the printer of the book, before ending with one final appeal that the author and printer should submit themselves to the Church of England to face censure. Compared to the Brief Survay, Burton's A Tryall is shorter and less strident, though it shares much of the same focus, attacking Cosin's purported popery and the printers and licensers who tolerated it. The title page lists Matthew 6:7, admonishing against vain repetitions of prayer, reflecting the Calvinist preference for extemporaneous prayer and rejection of formal prayer (though the set forms themselves do not feature prominently in the text of either tract). ${ }^{19}$ Burton writes two epistles, which, unlike Prynne's, target Cosin more than the press: one to the Church of England challenging Cosin's status as a loyal and true son for introducing superstitious rites and ceremonies and another to the reader, in which the authors suggests Cosin "rather expresses his Popish if not apish affection, in symbolizing with Jesuiticall catechisms . . . that giveth occasion of solid confutation, as being partly ridiculous, though mostly superstitious, and some erroneous" (sig. A3v). Thus, like Prynne, Burton challenges Cosin’s ceremony for being erroneous and superstitious. Some of this argument boils down to what amount, if any, of tradition is acceptable in worship practices. At the heart of their complaints, however, is that the press licenses more of these "Popish" and "Arminian" opinions than dissenting voices.

\section{Cum Privilegio - The True Complaint?}

The printing of Cosin's text, to the puritans, exemplifies the unequal treatment by London licensers. After the frontispiece and title page of the Private Devotions, the reader comes upon an "unusual but . . unexceptionable" approbation for the text. ${ }^{20}$ Dated February 22, 1626, it reads: "I Have read over this Booke, which for the increase 
of private Devotions I do think may wel be printed, and therefore doe give License for the same. Geo[rge]: London" (sig. A[1]v). To a modern reader, (especially one looking at an $E E B O$ scan) this note, the licensing of the text by the Bishop of London George Montaigne (1621-28), appears to be part of the bound text. However, as both Prynne and Burton comment, this was a "mere loose Paper, never joined with the Copy," whose very appearance was evidence of chicanery by the author or legerdemain by the printer (Brief Survay 93). ${ }^{21}$ Moreover, these thirty words represent the more substantial impetus of the puritan polemics: while Cosin should surely face censure for a book of popish poison, the greater danger to the Church of England is the rampant printing and licensing of Popish and Arminian texts, without giving the same privilege to puritan texts. ${ }^{22}$ Indeed, both of these polemics were printed without license. ${ }^{23}$ This conflict is especially apparent in the prefatory materials to both authors, though attacks against the printer appear throughout both works, such as in Burton's conclusion that criticizes the printer for not apologizing for including Prayers for the Dead. Prynne's dedicatory epistles make clear that he writes just as much, if not more, in response to the publication of Richard Montagu's works, for which the attacks on predestination went unpunished by the House of Lords, than Cosin's devotional itself. ${ }^{24}$ The critiques of licensing and the press have substantive merit. Seeing as how Laud would become Bishop of London in 1628, the year these tracts were published, the Laudian control of the press - in line with the stereotypical views of political Laudianism - was beginning its nascency. ${ }^{25}$

To be clear, both authors inveigh popery against Cosin's text and express dire concern over what they deem as official approval of Popish and Arminian texts, even if they do not define either adjective (which leads to some circular logic on the part of 
Prynne). Outside of his final condemnation directed to the printer "so ready to print Mountebanke Arminianism and cosening Popery ... with Authority" (sig. K3r), Burton primarily criticizes the press in his dedicatory epistle to the Church of England. Burton worries that the king's "Act of Prohibition for the suppressing of all Popish \& Arminian books" is being flaunted by the licensers and censurers, allowing such books that alter the "Communion Booke" to be published, full of such popish conflagrations like using "priest instead of minister," all while suppressing "Orthodox books" (sig. A1r-A2v). Prynne sounds similar alarm in his dedicatory epistle to the House of Commons. His opening salvo is his thesis, in which he praises the knights for their "pious zeale, and zealous pieitie, in questioning some Popish and Arminian Bookes ... by some spurious and Romanized, if not Apostalized Sonnes, and Pastors of our Church, to the inquietation of our State, the hazzard of our Church, the propagation of Popery and Arminanisme, to betraying of the truth ... and inexpiable blemish of our orthodox and Apostolicall Religion” (sig. ๆ2r). To Prynne, the lingering specter of popery serves to shame and undermine the English Church. The problem is that the high courts are failing to punish those who publish texts deemed contrary, by puritans, to the orthodox religion. Prynne cites the recent case of "Montague, Cozens, Jackson, and Manwering" who all escaped punishment (IIII 1v). Though he does not say as much, the historical record has shown some of this came through certain bishops intervening in the courts. ${ }^{26}$ Instead, he simply reiterates the problem: "What Popish or Arminian books; what Jesuiticall Treatises, or Romish prayer-bookes ... (which have beene lately scattered) and printed here among us in great abundance; ) have been of late anticipated, prohibited, or suppressed by them; though it be their proper Office to forestall, and crush them in the shell?" (sig. qๆ $1 \mathrm{v}$ - 
IIII2r). Though Prynne overstates the accusations of popery, he is right that the counterarguments are not being granted the same levity and privilege, as he announces in his fifth purpose of publishing this text. Likewise, his seventh demand, "that the two famous Universities of our Kingdome . . may be defaecated and purged, from all poisonous, Popish, and Arminian Doctrines: and that all such heads and fellows of Colledges ... [be] interrogated and examined," while exaggerated, may have been effective as well (sig. A2r). ${ }^{27}$ Laud's tutor at Oxford was none other than John Buckeridge, serving then as Master of St. Johns. And while certain Cambridge colleges would gain a reputation for harboring puritans, in a previous generation they entertained the misnamed "Lutheranism" of Peter Baro which was a precursor to Laudianism. ${ }^{28}$ All of this is to say that while Prynne and Burton engage in questionable rhetorical strategies to castigate their opponents over a disagreement in tradition and belief (to which we now turn), they do have a less contentious beef with the press, which practiced frustrating selectivity in allowing only certain texts licenses.

\section{A Different Type of Altar Controversy - a Jesuit Frontispiece?}

Perhaps the most contentious element to Cosin's Private Devotions was not what he wrote, but what critics took the book's frontispiece to represent. Called the "chief offendiculum" of the work, the frontispiece depicts a "Davidic altar border," which may have first appeared in the 1611 King James New Testament and was otherwise commonplace by $1627 .{ }^{29}$ At the base of the engraving is David strumming his harp, surrounded by two pillars, upon which rest two suppliants directing their gaze and prayers over an altar with a flaming heart towards a depiction of God's name, encased in 
clouds of flame. As Dyck comments, the puritans never mention the altar, effectually the keystone of the arch, suggesting that the altar with its flaming sacrifice either lacked “"popish' potential" or was not a "partisan title-page element." 30 The engraving, perhaps an appeal to those Catholic ladies at court, makes a few changes from the frontispiece that appeared in the KJV New Testament. Cosin's version replaces the usually male supplicants with two praying matrons (derisively interpreted as nuns; the 1635 reprint recasts the figure on the left as male) and exchanges the tetragrammaton for a Christogram (the letters $I H S$ ) enclosed in a sun supported by angels, which was enough for puritan critics to presume that a Jesuit veneer had infected the entire book with popery. I will first interpret the frontispiece as Laudian before turning to the accusations of latent Catholicism.

The Laudian potential in the frontispiece manifests itself through a reliance on the Psalms, as the Psalms are at the heart (literally, as depicted on the altar) of ceremonial worship practices and show the universal tradition of the Church. Two Psalms appear on the frontispiece. The words of Psalm 34:1, "Thy prayse shall be ever in my mouth," appear right above David's head, as if captioning his singing - the word mouth projects outward from the Psalmist's lips. The quotation has two resonances: first, it describes the mission of Cosin's work, which is to provide prayers for every hour of the day; secondly, its translation, repeated later in the devotional in the prayers for the ninth canonical hour, appears not from the King James or Geneva translations (which favor continually over ever), but the $B C P$ 's. Additionally, the alteration of His praise to thy praise supports Cosin's claim that the frontispiece serves to remind the reader to pray in Jesus's name. ${ }^{31}$ Arched over the altar's flaming heart are the words "The Sacrifice of a contrite hart," a 
paraphrase of Psalm 51:17 (KJV: "The sacrifices of God are a broken spirit: a broken and a contrite heart, O God, thou wilt not despise"). One of the Penitential Psalms, Psalm 51 appears throughout the liturgy, in the opening versicles, Lauds, and in the $B C P$ 's Commination against Sinners, where it is recited kneeling, as reflected in the gesture of all the frontispiece supplicants. The versicles, part of the Morning Prayer, draw upon Psalm 51:15 (“O Lord, open thou my lips; and my mouth shall shew forth thy praise"), which echoes Psalm 34. As noted above, while this altar is not taken to be a partisan image, the flaming heart occurs in many frontispiece engravings of this period. In most, the suppliants direct their gaze over the altar toward the name of God represented as the Tetragrammaton or the Christogram. ${ }^{32}$ For example, in the frontispiece to Lewis Bayly's Practise of Pietie (discussed in Chapter Three), a lone "pious man" directs the words "A broken heart o lord despise not" directly from his mouth to God, over a flaming heart. Extrapolating from the sermons in Chapter One, this image, for Laudians, represents the inner sacrifice of the heart, expressed through the body in prayer. The Psalms' widespread use in this period shows it to be an integral part of biblical worship patterns, not just those claimed by the Laudians. ${ }^{33}$

Whereas the Laudian interpretation of the frontispiece reifies liturgical worship practices, the puritan interpretation condemns the reintroduction popery into England, stemming chiefly from seeing the Christogram as a Jesuit badge. ${ }^{34}$ Prynne's primary conclusion that Cosin's work is "meerely Popish" arises initially from reading the frontispiece:

For, if you view the Fore-front of these Devotions, you shall finde these three Capitall letters; ( $I H S$.) incircled in a Sunne, supported by two Angels, with two devout Nunnes, or Women praying to it, one of them holding a Crosse in her hand. Now, what is this but an undoubted Badge, and Character of a Popish, and 
Jesuiticall Booke; of an Idolatrous, and Romish Devotion? Look into the Frontispiece of all Jesuits workes, you shall find this stampe . . Looke into your Popish Horaries, Primers, Offices, Prayers, and Devotions: Loe there a Crosse, a (IHS.) and men praying to them, or before them: but never saw I such a Fore-front in any Orthodoxe English, or Out-landish writers. (4) $)^{35}$

Prynne's complaint boils down to three points: the IHS badge, the women praying, and the presence of the cross. Of his points, one can be read a difference of opinion: where Prynne (and Burton) read the IHS as a popish symbol, Cosin sees it as the name of Jesus, a substitute for the normal Jehovah (see his correspondence in note 34 above). The praying women, however, clearly are not nuns: they are not in habits and do not have their hair covered. ${ }^{36}$ The cross, held by the suppliant on the left in both the original and the 1635 reprint, is a tool for devotion. It is neither, as Burton claims, "devoutly erected" (sig. C1v) nor, as Prynne claims, "supplicated unto" (6). The woman holds the cross as if it springs out of her heart towards the Christogram, and, in the later reprint, the man rests it over his right shoulder. What is more, in the Private Devotions, Cosin explicitly condemns cross-worshippers as offenders of the second commandment and only mentions the cross in the context of Christ's passion, never as an object of devotion (sig. C3v). In line with Buckeridge's defense against tendering devotion at the altar, the prayers are directed toward the presence of God, represented through the nomen sacrum. Such nuance is missing from the puritan attack. For instance, is it significant that Cosin's Christogram has an elongated omega over the three letters? In Burton's reprinting of the Jesuit badge, he includes the typical cross rising out of the $\mathrm{H}$ instead of the omega. For Burton, the badge is the "Name of Jesus," an exclusive appellation of the Jesuits that Cosin appropriates for "the new Ignatian Order . . . devoid of all Devotion" (sig. C1v). It is not a non-idolatrous representation of divinity. As a whole, Burton's reading is similar 
to Prynne's, though he extends the critique of the badge to mean that such devotions are not fit for one's closet, but the cloister: "What? Will the Author of this Booke make the Court a Monasterie or Nunnerie? Would he have the Ladyes and Mayds of Honour to turne Nunnes? . . . everie houre of the day, to turne over and over your Beads?" (sig. B2v). ${ }^{37}$ Burton's polemic suggests familiarity with the intended courtly audience but, as Ryrie notes, contends that the Book of Hours contains more Offices than individuals can observe in the course of the day, especially to those "earnestly imployed in worldly affaires." 38 The typical Laudian counterargument - that their tradition predates popery works, as the IHS dates to the $7^{\text {th }}$ century in Latin and the $14^{\text {th }}$ century in England (as it appears in Piers Plowman), well before the founding of the Jesuits in $1541 .{ }^{39}$ However, given the appearance of a Loyolan prayer later in the devotions, it must be noted that some of the traditional sources were, in fact, Catholic. ${ }^{40}$

Another factor to consider in reading the frontispiece to Cosin's Private Devotions is the revision of the engraving that occurred in subsequent editions, most notably in the post-Restoration editions that replaced the potentially Jesuit figures for royalist imagery. While I have not seen any references as to why the original engraving was replaced, its removal seems to either suggest a level of validity in the puritan interpretations, or Cosin and his publisher wanted to lend his liturgical ethos to the royalist cause. This frontispiece was reprinted until 1664, when it was replaced with a new engraving. Aside from the title, the only visual similarity in the latter version is the two pillars on the side. Instead of the Psalms, the base quotes one of the Epistles, "Pray without ceasing: 1 Thes. 5:17," which carries a similar thematic weight in encouraging continual prayer. In place of David and the praying ladies, the engraving has the English 
coat of arms at the base and, at top, the Royal arms, complete with lion and unicorn. The text itself has few significant changes, so the ethos is simply one of royal support, perhaps a visual affirmation of the Restoration against anti-monarchists. Opposite the title-page engraving is an image of Jesus, one not coded through a Christogram. ${ }^{41}$ Instead of humans praying towards Christ, Christ prays, framed by two Latin quotations: qui sequitur me in tenebris non ambulat, excerpted from John 8:12 (KJV: Then spake Jesus . .. I am the light of the world: he that followeth me shall not walk in darkness, but shall have the light of life) and Hebrews 5:7, cum clamore valido et Lacrymis preces offerens exauditus est pro sua reverential (KJV: "he had offered up prayers and supplications with strong crying and tears"). If the frontispieces establish a traditional ethos, the tradition shifts from David to Jesus, with Jesus's own gesture and method being represented through the devotions that follow. The post-Restoration revision offers less visual fodder for partisan or confessional rebuke. Nevertheless, the original publication cemented Cosin's reputation and imbued Laudianism with several Catholic-leaning stereotypes.

Because Cosin did not write about the frontispiece itself in his book, the image lends itself to subjective interpretations reliant wholly on the reader's disposition. The text of the Private Devotions, on the other hand, embodies the methodology of "Paatristic Reformed Churchmanship," in that Cosin's uses scriptural, patristic, and consular evidence to support the materials in both parts of his book - the primer, containing didactic materials and explications of Church practice, and the devotional, with the Book of Hours and the assorted set prayers that follow. This theological hermeneutic differs from the puritans, whose only source of authority is Scripture, and anything that comes from non-scriptural sources reeks of popish corruption. The interpretative question shifts 
from what an ambiguous image represents to what and whose authority is dogmatic and orthodox in terms of English practice. In what follows, I turn primarily to the material in the primer, for two reasons. First is that the didactic materials on the basic tenets of Christian religion are, pace Green, more polemical and confessional that commonly given credence. Secondly, Cosin's Book of Hours has been addressed more fully by critics. $^{42}$

IV. Whose Tradition? Catholic and Protestant Sources in Cosin's Primer Material From a puritan perspective, the following quotation encapsulates the danger of Cosin's text:

With a number of such like particulars, transcribed Verbatim out of our Primers, Breviaries, Horaries, Catechismes and Prayer Bookes: after whose formes and modell they are exactly framed: are directly broached, justified and approved? Doe not you see plainely by these, how they directly yeeld to us almost in every point of our Religion: Unlesse it be in the point of our Popes Supremacy, which they dare not breach as yet, for feare of incurring his Majesties displeasure (who cannot brooke an equall, or superiour in his owne Dominion: ) or for danger of the Lawes, which make this Doctrine, high Treason at the least: When we have never yeelded one foot or Inch to them? . . . as to suffer these our Popish Doctrines to bee taught and published, and so backed by Authoritie. . . (Brief Survay $86-87)^{43}$

In this passage toward the end of Prynne's tract, the author adopts a sarcastic tone in showing how texts licensed by the Bishop of London are advantageous to the Church of Rome at the expense of the Church of England. While Prynne's critique laments the error of the licenser and the lack of punishment for Arminian writers, this excerpt gets at the heart of the puritan reading of Cosin's material, which raises the question of whether representation is endorsement. That is, if Cosin quotes or adapts material that was written by a Roman Catholic, is the described practice inherently Catholic? Cosin answers in the 
negative, citing the authority of the Ancient or Universal Church. In this view, the Church of England reformed from, rather than against, Roman practices. An example of this can be seen in Cosin's framing of the Apostle's Creed, "the summe of the Catholike Faith.” Here, catholic means universal, as shown by Cosin's maniculed gloss: "By this Faith, (into which, and none but which, all Christians are baptized)," which does not distinguish confessional differences (sig. B11v). On the other hand, Prynne takes offense at the appearance of the materials: because they appear in similar form to (or are plagiarized from) Popish writers, Cosin is thus Popish. He first calls the Creed and the rest of the primer "all Popish trash and trumpery" without conceding any virtue for the material because they appear in Catholic primers (7). Only later does he provide a mild confession that the material has basis in Scripture and the $B C P$, but the "forme and matter together . . here paraleld" are only found in "Popish writers" (62). ${ }^{44}$ The scriptural origin for these materials is less important than the fact that Catholics have adapted the materials in their own works. Much of Cosin's alleged crypto-Catholicism comes from a deliberate blurring, where the substance is less important than its external appearance. ${ }^{45}$

One of the most contentious examples of this misreading has to do with Cosin's listing of the sacraments. Essentially complaining that Cosin is too irenic, the puritans ignore the otherwise deliberately Protestant frame of Cosin's explanation of the sacraments. The problem with Cosin's The Sacraments of the Church is that he has the gall to acknowledge seven sacraments without condemning the five that Protestants desacralized. The entire section reads:

The principall, and truly so called, (as generally necessary to salvation) are Baptisme and The Lords Supper.

The other five, that is to say, Confirmation, Penitence, Orders, Matrimonie, and Visitation of the sicke, or Extreme Unction, though they be sometimes called, \& 
have the name of Sacraments, yet have they not the like nature that the Two principall and true Sacraments have. (sig. C11r-v)

It is important to note that Cosin clearly distinguishes the two principal, salvific sacraments from those five "sometimes called" sacraments that "have ... not the like nature that the ... true Sacraments have." This distinction acknowledges that other traditions (i.e., Catholicism) recognize more sacraments yet shows that the English Church privileges only two. Additionally, the margin cites both Article 25 of the 39 Articles and the Church's Catechism of the Sacraments, which establish and recognize only two sacraments. ${ }^{46}$ In later editions, Cosin alters the ending to read "though they have been by some late Authors called by the name of sacraments (and so numbered)." ${ }^{97}$ Prynne's criticism - "Loe here a litterall, and manifest acknowledgement, and publication of seven Sacraments" - is that despite listing the church's official documents in the margin, Cosin does not condemn the Catholics for maintaining seven sacraments in his differentiation. Though Cosin admits that the five are not principle and true sacraments, Prynne writes that Cosin "doeth not exclude the rest from being true, or lesse necessary, and inferiour Sacraments" (21). In the midst of this deliberate misreading of Cosin, Prynne offers a somewhat valid criticism. Cosin, "quoting Scriptures for them in the margent," does provide scriptural evidence for those five nonessential sacraments (21). ${ }^{48}$ Burton's criticism falls along similar lines, arguing Cosin's church is not the "Mother Church of England" but Rome. Furthermore, Cosin does not do enough - "he must needs inferred that these his other five are no true Sacraments therefore false and bastard Sacraments" - in dismissing or discrediting the other five sacraments, as the $25^{\text {th }}$ Article and Catechism did in referencing the corruption of these sacraments through Catholic 
practice (sig. G1v-G4r). Here, the inclusion of the other five sacraments, despite explicit diminution of their status, acts as an endorsement of popish practices.

Part of Burton's allegations includes Cosin's alteration of the $25^{\text {th }}$ Article's "Penance" to the more popish "Penitence" in his full enumeration of the sacraments. Here, Burton's condemnation speaks to the actual practice of some Laudians partaking in auricular confession, even if they (the preachers) did not require their congregations to also do so. Burton writes: "Now Penance is a Popish word, and implyeth the Popish practice in this their Sacrament. Their practice is to injoyne Shrift, or Confession, to wit, a strict and exact enumeration of all a mans sins in the eare of the Priest ... emptying it selfe into a common sinke or Sewer. Hereupon he receives his Absolution" (sig. G4v). Part of Burton's criticism is the time-consuming nature of regular absolution. ${ }^{49}$ But his critique does have some merit. Though several proto-Laudians denied the sacramentality of penance and confession, echoes of the Catholic positions on priestly absolution and penitent laity are found in Hookers and Andrewes. ${ }^{50}$ However, some of this absolution occurs through the communion liturgy, not just confession. To the puritans' credit, Cosin's text itself promotes (but falls short of mandating) auricular confession and does so immediately above the listing of the sacraments.

While I will presently turn to all of Cosin's Precepts of the Church due to their distinctly Laudian and ceremonial flair, it is the fifth and final one that attracts Prynne's attention for inciting popery. In full, the fifth precept reads:

To receive the Blessed Sacrament of the Body and Blood of Christ with frequent devotion, and three times a yeere at least, of which times Easter to be alwaies one. And for better preparation thereunto, as occasion is, to disburthen and quit our consciences of those sins that may grieve us, or scruples that may trouble us, to a learned and discreet Priest, and from him to receive advise, and the benefit of Absolution. (sig. C11r) 
While Cosin's precept encourages private absolution, his argument is not unorthodox. His margins cite the $B C P$ twice: the second exhortation before communion, which encourages the laity to confess their sins before God and on their knees so as to better receive the Eucharist, and the "rubrick" at the end of communion, which lays out the three-time suggestion for communion. It also suggests that parishioners meet with their divines or curates, but to pay ecclesiastical dues rather than confess privately. ${ }^{51} \mathrm{He}$ also cites the Visitation Articles of Andrewes (which does not mention private confession, but encourages conferring with all communicants) and Bishop John Overall, whose $21^{\text {st }}$ article concerning ministers addresses both the administration of the Lords Supper and admonishing and exhorting troubled-conscience parishioners to resort to their "learned Minister" so that they "may receive the benefit of absolution, to the quiet of his conscience," which is likewise supported by the $113^{\text {th }}$ Canon (wherein "any Man [may] confess his secret and hidden Sins to the Minister for the unburdening of his Conscience, and to receive spiritual Consolation and Ease of Mind from him”). ${ }^{52}$ For Prynne, however, these ecclesiastical proofs (he cites all but the $113^{\text {th }}$ Canon) are insufficient. Instead, the fifth precept is "a pregnant proofe for Auricular Confession" directed to the "Popish Massing Priest," and he, like Burton, sees that "our Author had formerly enjoyned Shrift, or Auricular Confession of our sinnes unto a Priest, before the receiving of the Sacrament." $(20,27-28) .{ }^{53}$ While Cosin's use of Priest absolutely speaks to the administration of sacrificial rites, he, like the bishops in their Visitation Articles, encourages the especially troubled to seek out their ministers.

The other four precepts speak to larger issues of ritualistic observance of liturgy and sacrament - the precepts encapsulate most of the anti-Laudian criticisms seen 
throughout this project. Fittingly, then, at this juncture, Cosin jams in the most marginal citations in his devotional, with six different references to the $B C P$ along with citations of Visitation Articles and the sixth church canon - which unsurprisingly escapes puritan criticism, as it holds that "Impugners of the Rites and Ceremonies established in the Church of England" are "Wicked, Antichristian, or Superstitious" and should be censured through excommunication. ${ }^{54}$ At the risk of slipping into pedantry, while precepts have legal authorization, their role as "a general command" for conduct (in this case, ceremonial observance) is less authoritative than ecclesiastical canons, which nevertheless support the English Church's established customs. ${ }^{55}$ Cosin's precepts are as follows:

1. To observe the Festivals and Holy dayes appointed.

2. To keep the Fasting dayes with devotion and abstinence.

3. To observe the Ecclesiastical Customes and Ceremonies established, and that without frowardnessse or contradiction.

4. To repaire unto the publike Service of the Church for Mattens and Evensong, with other holy offices at times appointed, unlesse there be a just and an unfeigned cause to the contrary. (sig. C10v-11r)

Aside from reiterating the liturgical bases for these precepts, I will pass over their Laudian ethos, as all are covered elsewhere in this project (though Featley, below, will argue for conforming to the church's feasts and fasts) except for to note Cosin's sly insertion of "with other holy offices at times appointed" in the fourth precept. Though he cites the $B C P$ 's preface in support, the preface clarifies that the Morning and Evening prayer observance is required for priests and deacons - not the laity, though they are of course welcome to join. Cosin also marginally cites Cranmer's "Of Ceremonies" in support of the third precept. Burton cites Cranmer's essay, but he does so to accuse Cosin 
of "bringing in of old Popish ceremonies and superstitions" and suggest the devotions, primer, and hours, are ceremonies of the institution of man and pope (sig. E1v-2r).

To conflate the puritans' criticism of various parts of Cosin's text, the responses to feasting and fasting often appear in close relation to attacks on Cosin's use of the calendar of feasts and fasts, the section that inaugurates the primer portion of his text. Fasting, rather than feasting at festivals, receives more polemical response. Aside from Burton's somewhat typical puritan dismissal of "Feasts, Maskes, [and] sumptuous pastimes" (sig. C2r), the critique of festivals by Burton and Prynne mostly centers around those that appear in his ("tedious") calendar of moveable feasts, which carry the accusation of being Roman and not English holidays, and Cosin's solemnization of the marriage feasts. ${ }^{56}$ Fasting held an odd status in Tudor-Stuart England, where ceremonialists advanced a religious observation while the Calvinists were happy to rest on the state's civil and secular observation of Lent, which is the case here. ${ }^{57}$ Burton calls fasting "a part of Will-worship, and humane invention, [which] fills the stomacke of the Soule full of windy pride and hypocrisie" and is against the keeping of Lent as a fast, which is a "superstitious solemnitie" opposed to the state's "Civil regard" and "end" (sig. I1r-3v). Prynne reacts similarly, though he also takes offense at Cosin listing fasting as a "Good Work" along with prayer and alms-giving. Prynne rejects this formulation on the lines that "all Protestant Divines doe utterly deny [these works]: since Hearing, Reading, and Meditating of Gods Word: the Honouring, Loving, Fearing, Obaying, and Serving of God ... the keeping of all Gods Commandments, are as really, and properly good Workes as those" (22). For Cosin, the celebration of festivals and fasts operates on the 
same level as recognizing saints days - they are occasions, based on commemorating pious acts of devotion, that inspire and stir worshipers to their own devout acts. ${ }^{58}$

While the debates over tradition and authority feature prominently in the response over the sacraments and ecclesiastical precepts, perhaps the most deliberate misreading occurs in responding to Cosin's explication of the Ten Commandments. Under each commandment, Cosin clearly delineates and enumerates the "duties" of and the "Offenders against" the respective commandment, that is, how to observe the law and those who break it. At times, the puritans deliberately misread the offenders, presenting them as if Cosin is sanctioning idolatrous behavior. The explications of the second and fourth commandments have particular resonance with Laudianism, which naturally means the detractors gravitate to these commandments more than the others. ${ }^{59}$

In enumerating the duties of the second commandment (no graven images or idols), Cosin carefully toes the line in juxtaposing proper worship practices with idolatrous practices. Given that the commonplace accusation blasted against the Laudians is superstitious idolatry, such care should be expected. What makes Cosin's duties controversial is the creeping in of gesture:

2 To honor and worship with the lowly reverence, even of our Bodies also. 3 This to be religiously done unto him, and unto none but him; to his divine Essence, and not to the Images that men may vainely frame of him. 4 This also to be done purely, without any such outward and solemne worship to be given either to the person, or the Image of Saint, or Angell, or any other creature whatsoever. (sig. C3r)

Cosin's reverent gesture aligns with what we saw in Chapter One with Andrewes's conceptualization of the beauty of holiness and Buckeridge's adoration of divine majesty. ${ }^{60}$ This reverence is done to God alone - not the altar or elements of communion 
(this also refutes the puritan claims of saintly and angelic adoration). The list of offenders confirms the gestural churchmanship required of humans before God:

[1] They that fancie themselves any likeness of the Deity ...

2 They that make any other Images, or the likenesse of anything whatsoever (be it of Christ, and his Crosse, or be it of his blessed Angels,) with an intent to fall down and worship them.

3 They that are worshippers of idols...

4 They that are worshippers of Saints images ... the blessed Virgin, or any other Saint of God, do give a religious adoration to those usuall representments which be made them.

5 They also that are no due worshippers of God himselfe, that fall not lowly downe before his presence, religiously to adore him [sic] aswell with their bodies as their soules.

6 They that rudely refuse, or carelessly neglect to kneele, bow, and prostrate themselves, to uncover their heads; or to stand with seemely awe and reverence before the presence of his Majestie; as at all times of his service, so chiefly at the times, and in the places of his publike worship. (sig. C $3 \mathrm{v}-4 \mathrm{r}$ )

Indeed, these offenders could have been taken out of Andrewes's and Buckeridge's 1618 sermons, had they more overtly targeted those who worshiped poorly or inappropriately. In this explication, Cosin is careful to show God alone receives adoration and touches implicitly in the sixth offense upon those who presume not to submit themselves humbly before God in service or at worship, which could very possibly be directed at the courtly ladies for whom this devotion was intended (as we saw in Buckeridge's critiques and will see again in the devotions in Chapter Three and the poetry of Herbert in Chapter Four). The second offense rejects the notion of adoring the cross, so unless Cosin was inconsistent, this is another piece of evidence against the mere presence of the cross in an image being idolatrous, as with the frontispiece.

Such consistency and nuance are lacking in Prynne and Burton, who find many links to popery, idolatry, and the Jesuits in the explication of the second commandment. Against Cosin's first offenders, Prynne concludes that because God the Son and God the 
Holy Spirit are not mentioned, images of them may "be safely made" even though Cosin's text says "any likenesse of the Deitie." Through a bit of source manipulation, Prynne quotes "because they appeared to the World in a visible shape. (as hee pretends;) though God the Father, and the blessed Trinitie never did" as a (Catholic) defense to those allowed images (17). The italicized is similar to Cosin's Trinity and God the Father "who never appeared," though the margin identifies this as a Cardinal Bellarmine text. The non-italicized part of the quotation aligns with Cosin's reading even though Prynne purports it is does not. Because Cosin includes the phrase "with an intent to worship them," Prynne rationalizes that Cosin "approoves the making of Images" in and of themselves. Prynne makes a similar claim in arguing that Cosin is against the worship of images, but not against the worship of "them [pictures of Christ and the holy ghost] in their Pictures" (18). Citing the same passage of Cosin, Burton argues that Cosin leaves open the "defence of Romes Doctrine of the worship of Images." He continues: "a Jesuite with a distinction can easily make this good for his Doctrine, to wit, not to worship those Images, with the worship of Latria, nor otherwise simply, but with relation to the Prototype. So that ... the Authour implyeth, that some kind of adoration may be either given to the Image respectively to the Prototype, or at least before the Image, to the Prototype" (sig. F2r). ${ }^{61}$ Burton's reading deserves attention, partially because he never specifies what he means by prototype and, in this instance, he offers no alternatives to Latria, worship due to God (distinct from dulia, given to non-divine entities). Burton's readers would be familiar with typology as it is a standard practice in early modern sermons, where preachers bestow multiple layers of meanings to stories. If the images are bestowed with typological meaning, the Laudians may not have objected to directing 
worship to the prototype if that prototype were God. But, if that were the case, the images would be an aid to worship, not the target of worship itself, which is clearly and repeatedly allowed only to God. Similarly, Prynne argues that Cosin's emphasis of "outward and solemne worship ... due to God alone" means that he "only codemnes the giving of religious Adoration, to the bare Images, not the persons of Saints, and Angels . . . and the yielding, not of Religious worship, and Adoration [which is Latria] . . though they give that of Dulia, and Hyperdulia unto Angels, Saints, and Images" (19). ${ }^{62}$ If Prynne returned to the first commandment, he would find that Cosin did forbid any adoration to angels and saints, so his reading is not fully accurate. Lastly, Burton takes issue with Cosin's offenders who worship saint images for protection (which includes Mary) and give religious adoration to representations of saints. Burton's argument almost a strawman - is that Cosin "speakes nothing against Poperie, and so all his flourish but a mere froth" because Catholics do not teach that "Adoration of Images . . . is meritous. So that the author leaves it as granted, that a man may use Images in their Saint-invocation, so he account it not meritorious. Thus he is rather for Poperie in this point; then against it" (sig. F3r). Cosin mentions nothing in his explication about merit, so his failure to make a distinction - or, as was the case with the sacraments, a strong enough distinction - is therefore taken as a sign that he supports certain uses of images, which for the puritans is idolatrous regardless of context and situation.

When it comes to the fourth commandment (remember the Sabbath and do not labor), aside from some minor quibbles over works and almsgiving, the puritans have little to condemn about Cosin's Sabbatarianism until they come to the eleventh and final point which concerns sermon-centered piety. ${ }^{63}$ Cosin has a certain conformist flair in 
some of his duties - advising to "give God a solemne and a publike worship in the Congregation of his Saints" (matched by "They that neglect to be duly present and assistant at the publike Service of the Church, whereby God hath this day his solemne ... worship done him") and to "rest from unnecessary servile labours." He also aligns with more mainstream and left-leaning Calvinists, especially in his offenders of "They that put no difference between this solmne Festivall, and the common dayes of the week" and "They that spend it away in idle and vaine sports; that eat and drink, or discourse, or sleepe it away" (sig. C5r-6r). Aside from the "solemn Festivall," this resembles austere puritanical worship - perhaps not unsurprising, given Cosin's celebrity for harassing Durham parishioners for improper Sabbath worship.

It is the last listed offender that invokes the wrath of the puritan pen. In full, it reads: "They that under a pretence of serving God more strictly than others (especially for hearing and meditating of Sermons) doe by their Fasts, and certain Judaizing observations, condemne the joyfull Festivitie of this High \& Holy day, which the Church allowes, as well for the necessary recreation of the Body in due time, as for spirituall exercises of the soule" (sig. C6r). Cosin targets what he deems over-indulgence in sermon contemplation. This is one of the few places where Burton's response to a single point becomes quite lengthy (similar in style to the ranting of Prynne). Burton does not mince his words in accusing Cosin of making "all truly religious and conscionable serving of God" a hypocritical pretense: "Here we come more plainly to discerne the Wolfe in the Sheeps skinne, or in the Sheepherds cloke... Yea in this speech, he goes about to set open the verie Flood-gate of all profuse prophaneness" (sig. F3r). Burton criticizes Cosin's ambiguities in his "uncertaine" Judaizing observations and a lack of 
clarity in which "high and holy" days he refers to - Burton dismisses festivities such as Whitsun-Ales, may-poles, and masques. For the puritan, only a "religious and sober keeping of the Lords day" is allowed, with no wiggle room for anything but the "spiritual Sabbath," a distinction Burton makes through lengthy quotations of Augustine in an attempt to show the "church of God" forbidding joyful festivities. He also includes sermons and works of Bernard, claiming those two fathers - a favorite of pro-liturgy Laudians - for austere reflection, claiming an uncited passage where Augustine calls all festivities "prophane and impious" (sig. F4r). Burton makes a quite accurate distinction: "But our Author allowes of joyfull Festivity, and necessary recreations, in their due time onely; not in time of divine service." This is a true distinction in that Laudians do not ban or dismiss festivities with the same verve as puritans. Burton uses Bernard to claim that the Sabbath is for the sanctifying of the soul. To this Burton asks, "How come we to be sanctified, but by the word of God?" (ibid.) Indeed, "To heare Sermons, and not to meditate of them, is to receive water into a Sieve. . and "raze the very foundation, whereon all true religion is built" (sig. G1r). Where Burton argues that to hear and meditate a sermon is idle, Laudians would argue that meditating is idle when the divine service demands action and participation.

Prynne's critique, which also spans multiple pages, falls along similar lines: hearers are sanctified through preaching, which is "the very reading of the Word." Prynne, however, attacks "rare-preaching Ministers of superior ranke, (who have most time to con their Sermons, and their Prayers, because they Pray, and Preach so seldome)" who "bring [this practice] into fashion, especially, at the Court: from whence it should descend, Cum Privilegio" (78). He then asks, quite pointedly, how ministers expect their 
auditory to remember their exhortations if not to reflect on the words - reinforced by Prynne's truthful assertion that not all ministers, especially at court, memorized their sermons (suggesting that overwrought sermons were not memorable or able to inspire meaningful reflection). This leads him to question the profaneness of allowing sports and licentious pastimes to be allowed on the Sabbath - an unsurprising claim from the author of the play-denouncing Histriomastix. Prynne's claim against court preachers may be the most insightful - while James, especially, favored certain preachers and forced them to print their sermons (most notably Andrewes, who, as XCVI Sermons testifies, preached at all the major holy days at court), Prynne's mark of cum privilegio also speaks to his larger point about the Laudian and royalist press eschewing Puritan works, such as his own, or Peter Smart's sermon against Cosin's innovations at Durham, which was printed in Scotland.

This, finally, brings us to the core of the devotional, the Canonical Hours or the Divine Offices. Given Burton's title-page epigraph of Matthew 6:7's “vaine repetitions" of "much Babbeling," one might expect a condemnation of the set and formal prayers, but Prynne is silent on this, and Burton only passingly mocks the "unwearied devotion in the repetition of their prayers" of Romish ladies decked in beads (sig. B3r), continually stuck reciting the Pater-noster and Ave Maria and later mentions the repetition of "sundry Letanies" (sig. M3r). As a whole, set prayers become a greater concern in the decades that follow the initial publication. ${ }^{64}$ Most puritan critiques of the Hours have been well noted by critics, so I offer no new insight in reading the prayers themselves polemically. ${ }^{65}$ As mentioned above, criticism orients itself more so to the alleged popish sources, even though Cosin borrows most heavily from sixteenth-century Elizabethan materials, 
providing scriptural and patristic evidence and sources for each Office. Because they draw so heavily on established liturgy, the Offices in Cosin's prayerbook are relatively unremarkable. He provides little editorial commentary, save a brief essay on "The Antiquitie of the Mattins, or Morning Prayer," which for my purpose is notable mainly due to its reliance on the Venite as evidence for "holy men in all ages" to begin their day with service and this Divine Office (sig. E2r-v). Cosin's devotional is heavily sourced, which may be why Prynne focuses his critique on those sources themselves rather the substance and heart of what Cosin and those sources actually write.

The significance of Cosin's private liturgy book may not fully have been realized until the Restoration, when he helped guide the 1662 revision of the $B C P$. Nevertheless, in 1627 and 1628, after years of studying the liturgy, he reintroduced Elizabethan liturgical practices for the court and the public. ${ }^{66}$ With his own commentary and marginal notes, Cosin added a Laudian gloss to these traditional practices. In both public and private worship, Cosin and the Laudians believed a certain amount of ritual and ceremony were appropriate. What the puritan responses show us is a disagreement about the appropriate amount of tradition. The degree and vehemency in Burton's and Prynne's attacks show a reluctance, or outright refusal, to accept Cosin at his word because of what they viewed as crypto-popery. Instead of seeing Laudian ceremony as being compliant with Protestantism, they see the practices as being rife with Catholic abuses. The radical reading of Cosin dismisses the inherent moderation of citing a Christian tradition, that in their view, predates Roman Catholicism, in favor of incendiary polemic that favors the zealous brand of English Calvinism that took shape in puritanism. This debate unfortunately has clouded the way that scholars have read and limited the definitions of 
Laudianism. To support this claim, I turn now to Daniel Featley, who advanced a brand of conformity congruent to Cosin's prayerbook, but without attracting puritan attention, which in turn has led to him being considered an anti-Laudian, non-puritan conformist.

\section{Daniel Featley: A Case-study in English Protestant Conformity}

The appearance of Featley in this chapter serves three purposes: first, to highlight his vision of ecclesiastical conformity, which was nearly as ceremonial as Cosin's but less controversial; second, to demonstrate the unhelpfulness of a strict adherence to a Laudian-Puritan binary; and third, to transition into Chapter Three, where the survey of devotionals reveals a number of similar themes on the debate between public and private prayer, the use of gesture in both, and arguments against presumption. Featley's biography complicates the use of a single confessional label other than English Protestant, though Ryrie calls him a "bridging figure" between puritanism and conformists. ${ }^{67}$ As chaplain to Archbishop Abbott and ecclesiastical licenser (1617-1625), Featley demonstrates a puritan sympathy, having printed "a number of puritan works" and writing against "the Arminian school of theology, which he regarded as dangerously close to semi-Pelagianism and Roman Catholicism." ${ }^{68}$ Ian Green, in his book on catechisms described the Ancilla Pietatis supplement as having "not the usual content" (expositions on the creed, Lord's Prayer, and Decalogue) instead placing a "strong stress

on duties." He characterized Featley as "a Calvinist, a protégé of Rainolds and Abbot and a critic of Laud and Montagu" but noted that, in Ancilla Pietatis, "Featley devoted much space to defending the principle of celebrating holy days as well as offering extra prayers for the purpose." 69 Such a description fits the "conforming Calvinist" label. But during 
the Interregnum, when Calvinism slides more toward puritanism, he betrays a Laudian sympathy in refusing to change the railed altar at Lambeth, encouraging ceremonies, and supporting the episcopacy. ${ }^{70}$ Though anti-Arminian, Featley conforms to Laudian notions of ceremony, many of which depend upon the authority of the Church to establish and enact ritual practice.

One of the things that made Ancilla Pietatis Featley's “most popular and least controversial work" is its Protestantism. ${ }^{71}$ As mentioned in this chapter's introduction, Featley sought to increase the number of Protestant devotions written in English. If there was polemical intent, it was to be free of popery. For example, he writes "Popish superstition [has] over-cloyed" saint days but nevertheless includes devotions for observing them, using the "excellent patterne in the Booke of Common Prayer" (sig. A9rv). ${ }^{72}$ This Protestant ethos begins in the dedicatory epistle to the Duchess of Buckingham, on her "happy departure from the Romish Synagogue ... repairing to our true reformed Church" (sig. A2v). ${ }^{73}$ Later in the work, after a title page for the section Practice of Extraordinary Devotion (the part of Ancilla Pietatis on feasts, fasts, and hymns of devotion), Featley inserts another dedicatory epistle to the Countess of Denbigh, who also was the target of Richard Crashaw's poetry urging her to convert to Catholicism later in the century. ${ }^{74}$ The dedication to both of these women intimates a similar, if not shared, courtly audience with Cosin's text. Much like the Private Devotions, the work itself intends to be a manual for all occasions, organized in three sections: preparations for religious duties of prayer, hearing the Word, and receiving the Sacrament; set forms of prayers and hymns for every day of the week (with morning and evening devotions for each) and then extraordinary fast and feast days; and occasional prayers for the sick and 
women in childbirth. ${ }^{75}$ The main differences from Cosin are that Featley avoids the canonical hours, and while he uses patristic evidence, he only does so in the prefatory defenses, rather than the devotions themselves. Otherwise, the text presents a number of set forms for individuals to use in their religious exercises. The only suggestion of external controversy is the second edition's insertion that "beside the correction of many faults escaped in the former, There is added" a defense of the religious observation of Christian feasts, a discourse on the Lenten Fast, and directions for private Fasting (sig. a6v). This note has, to my knowledge, escaped scholarly attention, so one can only speculate whether these apologies were intended from the beginning or added due to political pressure. Perhaps this publisher's note escapes notice because Featley's conformity aligns with the mainstream English practice and is less dependent on traditional sources that may overlap with Catholic practices.

One piece of evidence for Featley's devotions being mainstream is its benign frontispiece: Featley allows for didactic use of images but does not advocate ostentatious displays of piety. The woodcut illustrates passages of Scripture and has far less latent potential for idolatry than Cosin's. Unlike the other frontispieces in this project, it does not depict an altar or flaming heart. There is little praying in the woodcut itself, although an angel, holding a banner that displays the words "Then another Angel: Rev 8.3" (Geneva: "Then another Angel came and stood before the Altar ... that he should offer with the prayers of all Saints upon the golden Altar, which is before the throne"), sits in radiant clouds atop the image surrounded by the words "Watch yee and Pray in Faith and Hope. ${ }^{, 76}$ The five women with torches and pitchers - likely the five wise virgins of Matthew 25 - orient their gaze toward the clouds, but none pray or supplicate unto it. The 
lone exception is the base, which illustrates the subtitle, The Hand-maid to Private Devotion: Presenting a Manuell to her Mistresse furnished with Instructions, Hymnes, and Prayers. Here one kneeling lady, "Handmaid," proffers a book with the word "Manu-ell" towards "Devotion," a courtly lady kneeling with her hands clasped together. Instead of the Davidic altar frame, six scriptural illustrations frame the text, showing scenes of witnessing closely related to Christological holy days - in clockwise order, Pentecost, the Ascension, Easter, Christmas (in two panels featuring the shepherds and the wise men), and, in place of Christ on the cross, a depiction of Moses lifting up the serpent with a caption of John 3:14 which typologizes the serpent for the Son of Man being lifted up. ${ }^{77}$ Above the title are two women lounging (one with a glass of wine), discussing an open book, which, like the handmaid and devotion, suggests private devotions can be a communal activity (an idea perhaps contradictory to the content of the work itself). Except for Moses (and the caption that contains the words of Christ), all the divine messaging comes from angels, so there is no apparent need to depict the divine through a Christogram or tetragrammaton. Thus, the woodcut avoids extremes and escapes censure.

While the frontispiece shows that private devotions can still be a communal activity, Featley's purpose is not to make common prayer private, as was Cosin's; Featley carefully balances private and common prayer, privileging public prayer over closet prayer, but pushing for more private activity ${ }^{78}$ His viewpoint aligns with we will see in the next two chapters. As elaborated in the "Preparation to Religious exercises in general," private prayer prepares one for public duties:

Premeditation is the Preparation to private prayer; private to publike; private, and publike to the hearing of the Word; private, and publike prayer, together with the 
hearing of the word to the worthie participation of the holy Sacrament. For the Sacrament receives strength and vigour from the word; the word preached from public prayer; publike prayer from private Devotion; and that from premeditation, and consideration of the nature of Devotion, and necessitie of preparation it selfe to all holy duties, in the immediate worship of God. (1-2)

For Featley, private devotion begins with self-preparation that extends to all aspects of religion, as demonstrated through worship. Proper meditation then leads to better worship, whether through private or public prayer, partaking in the sacrament, or hearing a sermon. In fostering all sides of this relationship, Featley's irenicism displays itself by not favoring or weighing one option above the other:

My intent is not to detract any thing from publike Devotion; but my desire is to adde to private Publike is more solemne, but private ought to be more frequent: Publike makes more noise but private (for the most part) hath a deeper channel. Our savior divideth blessednesse equally between them both: Blessed (saith he) is he that heareth the Word \& keepeth it: it is publike Devotion that heareth the Word preached, but private that keeps it. (6, quoting Luke 11:28)

Whereas Buckeridge and Andrewes take the polemical approach in criticizing sermoncentered piety, Featley, without targeting anyone in particular, frames positively the "private keeping" in which listeners can meditate and pursue the preacher's words. If Featley is pursuing a polemical purpose, it is not to dismiss public prayer entirely but increase opportunities for the English to practice in private. He takes a similar approach in arguing for set prayers. Careful not to dismiss outright extemporaneous prayers, "which must needs be suddaine as their occasions are and the motions of Gods spirit within us," Featley offers the reader set prayers with the stated direction to "ponder the matter, but even weigh (if wee have time) every word in the balance" (18-19). Extemporaneous prayers often run the risk of being vain, idle, or overwrought, as if they are "playing, not Praying," which is hypocritical in both private and public contexts (21). The irony to this argument is that vanity cuts both ways: critics of extemporaneous prayer 
point out the vain repetitions and phrases that some preachers have in their back pocket while critics of set prayer argue that reading them aloud has the potential for vanity when the speaker's words are not heartfelt. The words, like the actions, must be sincere.

Another core element to Featley's book of devotions, like many of conformist devotions in the next chapter, is the avoidance of presumption. Featley's explicit goal of avoiding ostentation and superstition relies on decency and order, those keywords of English Protestant worship. He differs from the typical Laudian line by applying these to the importance of closet devotion. Before showing examples and because this could be taken as evidence of Featley's anti-Laudianism, it is important to recall the rhetorical function of genre: the pro-liturgical viewpoints of Andrewes and Buckeridge stem from court sermons given on festival days. Featley here writes a devotional meant for private use, so naturally he elevates the importance of closet devotion (by contrast, Andrewes's private devotional was posthumously published with no preparatory rhetoric arguing the importance of private prayer), which, as in the previous paragraph, was taken to be preparation the religious exercises performed at church (diagrammed, sig. a2v, under "for ornament" as opposed to "for sent" or "for medicine"). Featley's definition of devotion, the "lifes bloud of religion" that "knit[s] the soule unto God" and is "a spiritual muscle moving only upward \& lifting up the hearts, eyes, and hands continually unto heaven" further clarifies that devotion connects Christian to deity in communication (2), whereas the Laudian worship focuses on the Christian's submission to God's majesty. While overlap occurs, here the location of the prayer aids the preparation for the individual to partake in those corporate moments. 
Most notable, then, in the importance of closet devotion is that it literally takes place in a closet. Featley writes, "For private Devotion (to shunne ostentation, and hypocrisie in heavenly things) alwaies shuts her selfe up in her closet, desiring no eye to see her but her Fathers in secret." In the abstract, this sentence could be thrown against Laudian notions of worship, except that Featley specifically refers to private devotion, which "if private Devotion cometh once to be knowne, it ceaseth to be private" (2-3). Moreover, he continues, "My intent is not to detract any thing from publike Devotion; but my desire is to add to private. Publike is more solemne, but private ought to be more frequent: Publike makes more noise but private (for the most part) hath a deeper channel ... Publike exercises of religion be their feasts but private their ordinary" $(6,8)$. For Featley, private and public devotion have a reciprocal relationship, where the private both keeps the public duties of worship and prepares the soul for participation in corporate worship. The types of prayers also play a role: "The powring out our special complaints to God ... a particular confession of our sins, aggravated by all circumstances ... are [as mentioned by Saint Paul] most necessary exercises of religion, yet cannot be so safely done, nor so decently, nor so effectually in publike as in private. These parts are not to be acted on the stage, but within the hangings" (8-9). This viewpoint concords with Cosin's precept for Eucharistic preparation (and the cited Visitation Articles). Though the communion service has communal confession, individual parishioners are encouraged to reflect before entrance to the church. Even when Cosin's preface argued for making public prayer private, the exigence of the argument was not to replace public prayer, but to supplement. ${ }^{79}$ 
Gesture plays a role in this supplementation between private and public devotion.

Pace Ryrie, who argues that kneeling outside the Eucharist was not controversial, there is nevertheless an extensive emphasis placed on kneeling, especially at prayer, for it to be dismissed as commonplace experience. ${ }^{80}$ For Featley, kneeling occurs at communion and in personal prayer alike. Mindful that private devotion prepares one for public worship, Featley's first reference (save the lifting of soul and body cited above) to gesture applies to communion, where he aligns with the Laudian practice:

But hath not the king of heaven and Monarke of the whole world more just cause to censure in the like manner, or more severely those among us that seeme most forward and to invite \& entertaine him who run into his presence without shewing any reverence; speake unto him without bowing their knee; heare him in the Ministry of the Word without uncovering their heads, so much as at the reading the text; participate of the dreadfull Mysteries (as the Fathers call them) of his blessed Body and Blood; sitting at the Communion as they doe at their ordinary table, without expressing any thankfull humility, or giving testimony, that they discerne the Lords body from common meat. Is this to serve the Lord Christ with feare? To rejoice unto him with trembling . . . to fall low before his footstool, because he is holy? (16-17)

In this passage, Featley echoes the concerns as expressed a decade earlier by Andrewes and Buckeridge, where ceremonial observance separates personal behavior from common settings. Gesture at communion couples humility with reverence in a (non-ostentatious) manner befitting the occasion. Those who treat the altar or communion with familiarity prophane the occasion rather than sanctify through due reverence (14-16). Featley elaborates on these concerns in a section on the duties before and after communion, where the first duty is to "Prepare thy body by a decent gesture" which is followed by direction to "recollect thy mind, and fixe thy thoughts wholly upon this most sacred action; stir up in thee" (94-97). While the meditation on partaking communion is important, the decent gesture (here ambiguous) precedes the reflection and, implicitly, 
helps stir up the appropriate affective response in the individual. Gesture, physical and metaphorical, appears in some of Featley's set prayers. In a post-communion occasion of thanksgiving, the prayer reads: "I bow the knees of my heart unto thee; I put my hands under thy sacred feet pierced with nailes for me; I lay downe before thee the keyes of my everlasting doore." In addition to resembling a line of Herbert, this prayer blends the language with gesture in giving over one's body completely to its "bountifull Saviour" (103). ${ }^{81}$ A prayer for Ascension Day plays with a similar dichotomy between physical and spiritual gesture (key to the Laudian understanding of gesture): "I humbly bow the knees, not only of my body, but of my heart and soul unto thee" which is followed by a confession that "I never heare of thee, or remember; never thinke, or speake of thee but with greatest reverence" (488-89). ${ }^{82}$ In all of these, Featley, like his Avant-Garde Conformist predecessors, carefully specifies that gesture is never for the sake of external show, but to represent one's inner reverence and pious behavior.

VI. "And if this bee superstition, what is Religion?" (536): Addressing the Controversies of Fasting, Feasting, and Saints

Many conflicts in English Protestantism ultimately fall to what constitutes proper, pious behavior. ${ }^{83}$ Cosin, in showing continuity from Catholic practices, veered too close to that tradition for puritan tastes. In his devotional, Featley, like Cosin, promotes feast days and private fasts. Not only does Featley escape critique, but Prynne cites Ancilla Pietatis on the propriety of fasting in the Brief Survay. ${ }^{84}$ While the second edition of Ancilla Pietatis contains an apology for the inclusion of feast and fasting days, the devotional material was present in the first. In his viewpoints concerning sabbath and 
feast days, Featley channels Hooker, which aligns him with the tradition of the AvantGrade Conformists, though without the presumed anti-Calvinist or anti-puritan bent. Published almost halfway between the Articles of Perth and the Scottish BCP, Ancilla Pietatis endorses the established ecclesiastical calendar, and, with its emphasis on Christocentric festivals, could almost be seen as propaganda for the holiday cycle. Featley's methodology, however, allows his support for the established church's practices to be subsumed by and made auxiliary to the models of private devotion he provides.

That is not to say he does not have argumentative moments - his apologies for feasts and fasts offer non-devotional prose to augment the devotions.

Though he draws on some patristic sources, Featley supports the celebration of feast days by taking a Christocentric approach. While the manual is literally a quotidian devotional, with devotions for each individual day of the week as well as the Sabbath, Featley also offers devotions for "feasts peculiarly dedicated to our Savior and the holy Ghost," to which he ascribes a nearly sacramental importance. He writes:

For whatsoever scruple hath beene made of Saints dayes, the whole world as farre as it is, or ever was Christian, hath observed religiously, these feasts as Monuments and a kind of Sacraments to refresh the memory of the chief workes of our Lord, and mysteries of our faith, to checke and controle whose universall \& uniforme practice, especially in a matter of this nature is most insolent madnesse. God (saith Paulinus) hath garnished the Church Calender with festival dayes, as the heaven with Starres, or a garland with roses. . . Doubtlesse then the festivals in special consecrated to him [Christ], out to bee as the fairest flowers in the round garland of the yeere, and the brightest Stars in the Church-Firmament. We never read of any (Saith Calvin) that were blamed for drawing too much water out of the well of life: Neither can we possibly give too much honour to the King of glory. Saint Bernards consequence is as sound as it is pious. If we celebrate the Saints solemnities, how much more ought we to keepe his who made them Saints? (115-17)

Featley's dismissal of the scruples against celebrating feast days as "insolent madness" falls along fairly typical Laudian lines: festivals, as evidenced through allusions to 
Paulinus and Bernard, have been a part of the Ancient and true Church, which is why the English church continues to observe them (not to mention the Calvinist ethos of citing Calvin himself). ${ }^{85}$ Moreover, it is God, rather than the Church, that instituted these holy days. The goal is not the festivities themselves but their use as monuments and "a kind of sacrament" to stir up the memory of Christ's own actions. This commemoration of holy actions is the same argument Cosin will make about saint days reflecting the holy trinity. ${ }^{86}$ Here, channeling Bernard, Featley emphasizes that saintly "solemnities" reflect more on the creator of the saints, rather than the saints themselves. Holidays offer occasions for individuals to focus their devotions on Christ, with whom Christians communicate through private devotions. This funneling of devotion allows Featley to distinguish Christ-centered festival days from saint days.

Although he "purposly omitted" holidays for saints, martyrs, and archangels, Featley supports the keeping and observation of them, provided two important caveats are met: that worship on these occasions is tendered to Christ rather than the saint, martyr, or archangel and that such worship occurs in the communal practice of the church rather than in private devotions. In his rationale for his scope and method of the devotions, Featley elaborates on the second caveat for omitting saint days: "not that I dislike the keeping of them; for I have ever, and will justifie and maintaine the observation of them, according to that godly institution, and practice of our Church. But I desired to keepe my booke within the compasse of the title, which is a Manuell" (117). ${ }^{87}$ Because the church observes feast days for the saints, they are therefore worthy of attention - as he argues in the later section "Of Christian Feasts." As for the manual's contents, the weekday devotions are based on the words of Christ, so Featley's handbook 
focuses on iterations of the divine, rather than human, mirroring Cranmer's ceremonial methodology. In defense of English festivals against the "gaudy Relique" of "Romish superstition," Featley argues that "no religious Devotion or worship is performed to the creature" (of saint, martyr, evangelist, or apostle) but that "these high Feasts [are] only dedicated to the honour of our Redeemer," demonstrating that "on such daies we sanctifie God, we Deify not Saints: wee blesse God for them, we worship them not for Gods." He continues, saying this is the result of "the [sic] renowmed Authors of the reformation in England, [who] carefully applied their pruning knife, cutting off all superfluous festivities" (409-411). ${ }^{88}$ In this manner, Featley embodies the Laudian argument for conformity in showing the English Church to embody the practice of the universal church having cut off the superstitious errors of Catholicism. Featley's argument that festivals recall the "chief actions \& passions of our Savior, that in future times they might not bee forgotten" sounds like the same argument Cosin will make for saint days (407) ${ }^{89}$ Moreover, the connection of festivals with the sacraments, in which these occasions reveal the "special benefits derived to his Church by those golden conduits of his bounty and grace" (410-11), recalls the sacramental language common in Andrewes's festival day sermons, coincidentally published only a few years after Ancilla Pietatis. ${ }^{90}$

Part of Featley's Laudian tendencies stems from his explicit endorsement of Hooker's ceremonialism, which opens the essay "Of Christian Feasts." ${ }^{\text {"1 }}$ This essay responds to those "religiously devoted persons [who] should goe about to deface, much more utterly to expunge them [feasts] out of all books of Common-prayer and publike Devotion. . . I see no reason why any should distast Feasts dedicated as well to Charity as Pietie; which were thought necessary to the service of God, and solace of men, so 
agreeable to politie and Religion" (399-400). Like Hooker and Andrewes before him, Featley supports what the church has inherited from universal tradition. Featley, after quoting the Fifth Book of Hooker, says "the [sic] renoumed Author of Ecclesiasticall politie gilds over the Rubrikes of our Church Kalendar" through explaining that "Feasts are the splendor and outward dignity of our religion, forcible witness of ancient truth" (399). Like gesture for Andrewes and Buckeridge, feast days for Hooker and Featley provide the occasion for outward shows of religion and "exercise of all piety." Featley's polemic targets those, like Prynne and Burton, who "hold it superstition, to place holiness in times ... Judaisme, to keepe strictly set days . . Popery, to honour Saints with Festivals; and will-worship to ordaine any thing in the service of GOD without precise warrant from the Word" (401). ${ }^{92}$ Featley responds to these in turn, defending the tradition of the church from scriptural and patristic precedent. His responses resemble Laudian arguments for conformity that we have seen elsewhere in this project: he argues that "Holinesse is twofold, inward and inherent, outward and relative," dismissing the lack of "inherent holinesse" in times and places, which are sanctified by God through "holy actions done in or upon them by God or man" (401); that the church rubric adapts Jewish holidays through evidence of St. Paul and other Church fathers, such as Tertullian, Ambrose, and Augustine (403-406); that "Our Church neither observeth and Jewish or Heathenish Feast, nor any Christian Feast, after a Jewish or Heathenish manner" (408); and that the English Church has done away with Roman superstitions (409-13). Festival worship is an outward show that is appropriate through its ecclesiastical sanction and its focus toward the Godhead alone and not any material elements that, to echo the words of Cranmer, were instituted fallaciously by man, rather than Scripture or universal tradition. 
To highlight one of the examples cited above, Featley's Laudian sympathies are most apparent in his response against superstition, in which he channels an Andrewesian beauty of holiness, where feasts are celebrated in the temple to represent the holiness of God. There are implicit echoes of the orderly and decent demonstrations of worship that are bound up in festival observance:

Holinesse is twofold, inward and inherent, outward and relative. Times and seasons have no inherent holinesse in them no more then places; yet certain times and places are denominated wholly by reasons of holy actions one in or upon them by God or man. God sanctifieth times and places, either by precept or by particular presence, or special worke. Man sanctifieth them, either by dedication of them to divine service, or by celebrating divine service on them. As Gods particular presence makes the Place an holy Temple, so his special work on the day make the day a Feast . . . [elaboration on God's work and presence; their impression on time and place] whereof man taking special notice expresseth his thankfulnesse to God for them both, by consecrating both unto him; the one for the place, the other for the time of peculiar worship. To deny them therfore the outward or relative holinesse is prophannesse; as on the contrary, to ascribe unto them inward or inherent holinesse is superstition: religious Devotion holdeth the path of Gods Commandment, neither declining on the left hand to prophannesse, nor on the right to superstition. (401-403)

The ellipsis covers Featley's quotations of Exodus 3:5 that marks God's earthly presence in holy places and Psalm 118:24's call to rejoice in the Lord's Work (the latter, coincidentally, serves as sermon-text for Andrewes's 1606 Gunpowder Plot sermon on the inaugural festival commemoration). Featley implies that Christian festivals are all commemorations explicitly concerned with Christ's work while alive and it is the divine presence that sanctifies the temple. Similarly, the reference to profaneness without recognizing the appropriate blend of internal and external echoes Bayly's Practise of Piety, explored below in Chapter Three. Ultimately, Featley's demonstrations of holiness require proper practice that eschews both excess profaneness and superstition. ${ }^{93}$ Ceremonial worship - apropos of the Hooker opening of Featley's essay - requires 
moderation in ceremony and festivals, even if both are nonessential to Christian duties and obligations. Their nonessential quality, however, does not make them inherently superstitious or errant, as the puritan criticism (as presented by the proto-Laudian writers, at least) seems to suggest. Adiaphoric worship goes hand-in-hand with private devotions as they are gestures to stir up one's sense of piety through causing an individual to reflect - on their own humble status compared to the work that Christ (as redeemer) has already done on their behalf, which is a dominant theme of Herbert's poetry, as we will see.

To transition via Hooker: "Having therefore spoken thus much of festival days, the next that offer themselves to hand are days of pensive humiliation and sorrow."94 Following Featley's devotions on the Christocentric festivals are his explanations and prescriptions for personal and private fasts, in which he takes a moderate, via media approach. Featley first identifies the "present practice" of the Church of England, as derived from the Ancient Church, in prescribing fasts (507). As mentioned above, Prynne actually cites Featley on the fast, though Prynne's abhorrence of Ember Day/Week observance (among other factors) does not align with Featley's apology for fasting. ${ }^{95}$ As Hampton has shown, the status of fasting in England was anything but uniform. ${ }^{96}$ However, Featley's demonstrates his moderation through The "right Use of Religious Fasting," which consists of sincere, non-hypocritical practice that is measured and done in order to tame the flesh, testify of humility and sorrow for sins, and quicken zeal and devotion for temporal blessings. ${ }^{97}$ He admits that "the Doctrine of fasting hath met with errors and superstitions on both hands" of over-subscribing their use and ignoring them altogether; Featley seeks to "steere the judgment in a middle course between these rocks on both sides" - of those who make fasting the "principal worship of God" and those who 
make "it no matter of Religion at all" - in making fasts a supplemental religious act to the principal duties of faith and prayer (508-9).

Though Featley takes a moderate approach in arguing to fast, he takes a traditional, pre-Roman Catholic approach in citing the Ancient Church as founders of the practice. This largely aligns him with Laudian viewpoints. In "Of the Lent Fast," an essay which he greatly expands in the second edition, Featley subscribes to the authority of the "Christian magistrate, civil or ecclesiastical" as the "lawfull Superiours in Church or Common-Wealth" in prescribing fasts in ordinary and extraordinary times, the latter being events such as in times of plague (521-22) ${ }^{98}$ Much of the essay is a typical tract outlining Gospel and patristic support for keeping Lenten observations, including citing an error of those who only practice devotion at Lent. ${ }^{99}$ Featley is adamant that Lenten worship is Protestant (he later cites Swiss and German churches) because the practice predates popish pollution, claiming that Romanists enforce the fast with the threat of damnation. ${ }^{100}$ Like much of his private devotions, one of the goals of fasting is to "prepare our selves for the most publique, sacred, and solemne participation of the body and bloud of our Redeemer at Easter" (540) - a notion that we will see again with Herbert in Chapter Four with his poem on fasting and the poetical sequence leading to Easter. Before his Lenten devotions, Featley includes a short catechism (also expanded in the second edition) that outlines the practice as divinely inspired, civilly instituted, not modeled on Christ's miraculous fast, and not Popish. ${ }^{101}$ Thus, Featley's defense of fasting leads into those actions Christians can do to exercise their piety in shows of devotion. The explicit emphasis on actions is also a key part to the second part of Ancilla Pietatis, 
the catechism that, after the first edition, was published separately as The Summe of Saving Knowledge.

\section{Featley's Catechism \& Conclusion}

Featley's catechism nicely supplements the devotional manual. The catechism embodies Featley's shared beliefs in predestination and in active and outward worship, outlining duties for laity and pastors. ${ }^{102}$ Where Ancilla Pietatis contains devotionals for every day of the week, The Summe of Saving Knowledge has a weekly subdivision of 52 lessons for the Sunday duty of catechizing all under a roof in in the "grounds of true religion ... all necessary points of Faith, and special duties of holy obedience required of

every man, in what place, state, condition or calling so ever he be" (sig. A2v-3r) ${ }^{103}$ These duties repeat the original outline of Christian religion in the first pages of Ancilla Pietatis. Catechists attain the means of salvation and principles of religion through hearing the Word preached, receiving the sacraments, and public and private prayer (3). Featley's language echoes other Laudian explications of religion and service: this "true Religion, or godliness; which hath the promise of this life, and the life to come" is defined as "the true worship of, and service of the true God" in adoration, performance of holy rites, and obeying God in duties to self and neighbors (3-5). Naturally, Featley defines worship as both inward and outward acts. Inward worship reflects faith, which includes the religious virtues, such as humility, reverence, and repentance. Outward worship reflects the means to salvation: "By hearing the word; receiving the Sacraments, Prayer, profession of our faith, keeping the Sabboth, and the religious use of Oathes and Vowes" (28). In keeping the Sabbath and hearing the Word, Featley admonishes individuals to stay active, by "sequestring [the Sabbath] from our accustomed business, and dedicating it to the 
immediate worship of God, and his peculiar service," which, like sermons are to be heard by "repairing frequently to the Church; there reverently, attending to the Word read, or preached, seriously meditating upon it, and endeavouring to practice it in our lives and conversations" (28-29). In these exhortations, the church is the location for reverent service and active attention.

While Featley does not bring in gesture, even when talking about preparation for the Sacrament (as others will do in Chapter Three), he does emphasize attentiveness and proper action, even in rituals. ${ }^{104}$ This is seen through the duty of the pastor, who, in addition to studying Scriptures, leading prayers for the congregation, preaching both faithfully and zealously, and administering sacraments, is to "exercise such Ecclesiastical discipline ... according to Gods Word, and the Canons of the Church" and "To conforme themselves to the holy and decent Orders of the Church, performing all Rites and Ceremonies enjoined by it; as readying the Litturgy, Marrying, Burying, \&c.” (50-51). Pastoral duty for Featley maintains orderly and ritualistic worship as ordained by the state church structure. While he need not emphasize the gestural elements explicitly, so long as the official church endores them, Featley maintains that the congregant should participate in the service. Or, at least if the pastor tells the individual to do so: in the following section, on the duties of the flock to the pastor, the catechist is instructed "To heare their owne Pastour diligently ... To obey him in the Lord . . . [and] To have him in reverent account" (52). As with Bayly before him, Featley leaves room for the congregant to follow the practice of their individual pastor, to obey their exhortations as laid out in sermons and liturgy. Ideally this would reflect the official church position throughout England, but the practice leaves room for moderation and individual clergy altering the 
corporate liturgy for their own purposes and designs. Ultimately for Featley, worship should be corporate but dependent on individual participation.

$$
\text { **** } *
$$

This chapter presented two devotions that approach Laudian conformity in different ways. Cosin sought showing the continuity with tradition, whose similarity to Catholic practices stemmed from the practice of the Ancient and universal Church. Featley sought to separate English devotional practices from Catholic, though he still conformed to the established practice of the British Church. In writing about Laudian devotionals, there are two glaring omissions, the devotions written by Lancelot Andrewes and William Laud. I pass these texts over for a few reasons: they were published posthumously and many have competing editions. For example, Henry Isaacson's initials appear on the title-page woodcut of the 1630 Institutionae Piae and while it draws heavily from Andrewes's Preces Privitae, first published in English in 1647, it is unclear how much is his own work and what derives from Andrewes. Laud's Daily Offices appeared in a few different editions, with the subsequent ones becoming longer. In the next chapter, I broadly survey devotionals written by a wide array of authors with different levels of success and popularity. Rather than focus on the explicitly and ostentatiously Laudian elements, I instead offer evidence for moderate views of Laudianism and liturgical conformity in public and private life from authors, like Featley, not commonly considered Laudian.

\footnotetext{
${ }^{1}$ Veith, Reformation Spirituality, 43, alludes to Edmund Bunney's retort that Englishmen read the theology of Luther and Calvin for their devotions (see also Ryrie, Being Protestant, 286). Later, 184, Veith mentions many English devotionals were patchworks of Scripture; with the Wordfocused emphasis of Protestantism, the two together (along with the emergence of the $B C P$ ) may help rationalize the disparity. For an overview of the Protestant-Catholic devotional dynamic see
} 
White, English Devotions, 64-5, or John R. Yamamoto-Wilson, "The Protestant Reception of Catholic Devotional Literature in England to 1700," Recusant History 32.1 (2014): 367-390.

${ }^{2}$ This argument runs counter to Gregory Salazar, "Daniel Featley and Calvinist Conformity in Stuart England" (PhD diss., University of Cambridge, 2018), 183-187, who posits Featley as working against the anti-Calvinists. He compares Ancilla Pietatis to Cosin's Private Devotion, arguing that Cosin stresses continuity (which is true) while Featley diminishes the value of the liturgical calendar, which I take as less true. Moreover, he argues, 185: "While it is tempting to accept Prynne and Burton's assessment that Cosin's work was crypto-popery, a more persuasive reading is that Cosin was driven by pastoral considerations not altogether dissimilar from those that motivated Featley's anti-Catholic works - namely, to curb wavering Protestants from converting to Catholicism." While Featley did license puritan works when a press licenser, I disagree with Salazar's dismissal of Featley's Laudian potential, though it is refreshing (cf. Doerksen) to see an admission of Laudian pastoral sensibilities.

${ }^{3}$ Green, Print and Protestantism, xl-xli, and Christian ABC, 26-34, emphasize that many devotions overlap in materials, usually concerning themselves with the Lord's Prayer, The Creed, and the Ten Commandments - all present in Cosin's devotional with his Laudian glosses.

${ }^{4}$ See Ryrie's overview of this relationship, Being Protestant, 281-92, especially 286.

${ }^{5}$ Stanwood cites both sources, Sempiternal Season, 111-12.

${ }^{6}$ The Articles or, Charge Exhibited in Parliament against D. Cozens of Durham (London: 1641), 1-2. The charges were almost certainly drafted by Peter Smart, who in a 1628 sermon, chastised the practice of ceremonies inspired by Bishop Richard Neale and Cosin. Sermon Preached, 6: "And what are Ceremonies? are all vaine? are all superstitious: God forbid. . . Most are ridiculous, and some abhominable." This work would be republished in the 1640s as The vanitie $\&$ downe-fall of superstitious Popish ceremonies.

${ }^{7}$ Stanwood, Sempiternal Season, 100.

${ }^{8}$ Ryrie, Being Protestant, 90 and 215. Parry, "Tradition of High Church," 43. The last quotation is Stanwood, Sempiternal Season, 102. For Cosin's anti-Catholicism, see also Arthur Middleton, Fathers and Anglicans: The Limits of Orthodoxy (London: Gracewing, 2001), 157, who highlights Cosin's anti-Catholic tracts written during the Interregnum.

${ }^{9}$ See Stanwood's comments in John Cosin, A Collection of Private Devotions, edited by Stanwood, (Oxford: Clarendon Press, 1967), xxvii-xxxiii, for Cosin and this text as being "typically Laudian" while differentiating it from the Catholicism of Cosin's time. Xxxvi-xxxviii briefly examines the puritan response.

${ }^{10}$ See Davies, Carolinian Captivity, 46-48, for Prynne's "perversion of evidence" and the assertion that "underlying much current historiography is a notion of Laudianism which is little different from that of Prynne's."

${ }^{11}$ Cosin, Correspondence, 138-39. This letter dates from 1628. The Latin is a paraphrase of Psalm 39 (KJV: "I said, I will take heed to my ways, that I sin not with my tongue"). The collection also contains a letter, likely intended for Bishop Neile, that responded to 32 objections levied against the prayerbook.

${ }^{12}$ Stanwood, Sempiternal Season, 113.

${ }^{13}$ Stanwood, Sempiternal Season, 113; L.W. Hanson, “John Cosin's Collection of Private Devotions, 1627," The Library 13.5 (1958): 284.

${ }^{14}$ Hence the description of the Anglican Church as "Catholic and Reformed" (the title of works by Anthony Milton and Florence Higham).

${ }^{15}$ As demonstrated in Prynne's listing of English defenders of the faith against "foraigne Enemies" and "Romes Master-Champtions" that begins with Tyndale and includes Fox and Jewell before naming contemporary puritan-leaning Calvinists like Reynolds (of the first Hampton Court Conference), Perkins, and Willet. Brief Survay, sig. I[2v.

${ }^{16}$ For Primers in the Tudor period, see White, Tudor Devotion 53-133; in the Carolinian context, Stanwood Sempiternal 103-106, which includes the claim about the rise of the $B C P$ (and other 
devotionals). See also Stanwood, ed. Collection, xxii: "The Devotions is properly described as a Primer, and belongs therefore to an old tradition of Christian devotion, while the provision it makes for the observance of the canonical hours of prayer associates it with an even older and more universal tradition."

${ }^{17}$ Spinks, Incomparable Liturgy, 37.

${ }^{18}$ The variety of purposes is also reflected in the work having four separate title pages (plus multiple subtitles throughout).

${ }^{19}$ The eschewing of formal prayer is most clearly and officially seen in the Directory of Public Worship (1645) that suggests the Lord's Prayer is just a suggestion rather than something to be repeated verbatim. See the Conclusion, below. Burton's title page quotes the Geneva: "When yee pray, use not vaine repetitions, as the heathen, or hypocrites doe; for they thinke that they shall bee heard for theyr much Babbeling." It also cites the Glossa Ordinaria on Matt. 6:6: "in fide interiori \& dilectione oratur Deus: non strepitu verborum, sed devotione virtutum" [my trans: God is prayed to by interior faith and love, not by the sound of words, but the virtue of devotion]. Henry Burton, A Tryall of Private Devotions. OR, A Diall for the Houres of Prayer, (London: 1628).

${ }^{20}$ Hanson, 283. He continues, 283-4, with Prynne's and Burton's responses to this.

${ }^{21}$ Cf. Tryall, sig. K3v: "onely an Individuum vagum written in a loose Paper."

${ }^{22}$ See e.g., Tryall, sig. M2r: "A booke of Devotion is a golden cup of sprightful wine . . but if it be mingled with poison" or Brief Survay, 102: "all those hidden vaines, wherein the Romish and soule-slaying poison of these Devotions lye."

${ }^{23}$ Comparably, most of the tracts against kneeling after 1618 were published in Leiden instead of London.

${ }^{24}$ Stanwood, ed. Collection, xiv-xv, provides a succinct overview of the debate around Montagu's text, including the reference in Appello Caesarem (1625) where "the Church of Rome is a true Church though in error." See also Lambert, passim, but esp. 52-58. For Laud's complicated relationship to Montagu, see Anthony Milton's "Laud, William (1573-1645), archbishop of Canterbury," Oxford Dictionary of National Biography (23 Sep. 2004; accessed Mar. 3, 2021), "At court, 1621-25," para. 3.

${ }^{25}$ Davies, 113.

${ }^{26}$ See also Brief Survay, 82-3, which repeats the claim of licensing "to the shame, and scandal of our Church and Prelates, who ought for to suppresse them."

${ }^{27}$ See also Prynne's first purpose, sig. $9 \uparrow 4$ r: "to suppresse those Popish Devotions, and Arminian Treatises, which have been published of late among us by approbation and authority: and to expiate; defecate; and purge out their Romish and Arminian drosse and filth, at least by fire; that so they stand not as Records against us, to the shame, the weakning, or betraying of our Cause, the Chuch." And his fifth, A1v: "to provide; that all such unauthorized Answers and Replies consonant to the established Doctrine and Discpline of the church of England, which have beene given to Mr Montagues, or any other such Popish or Arminian Bookes, and since suppressed; may be henceforth lawfully printed and dispersed without control, to counterplead and beat down Popery and Arminianisme."

${ }^{28}$ On Baro's "Lutheranism" leading to Laudianism, see Trever-Roper, 47-50. Conversely, Fincham, 231, argues that Arminians likewise pointed to the universities as part of their fear of the Calvinist ascendancy. See also Patrick Collinson, The Religion of Protestants: The Church in English Society 1559-1625, (Oxford: Clarendon Press, 1982), 61: "So the topic of bishop-making belongs as closely to the history of the universities ... as it does to court patronage" or 81 , on the antagonism anti-Calvinists received at the universities.

29 "Chief offendiculum" is Ornsby, ed. Correspondence, xx. For "Davidic altar border" see Paul Dyck, "Altar, Heart, Title-Page: The Image of Holy Reading," English Literary Renaissance 43.3 (Autumn 2013): 559. Dyck's article reads Herbert's "The Altar" in line with this tradition, which 
he traces back to Bible woodcuts. He includes both Cosin and Bayly (discussed in Chapter Three) in that tradition.

${ }^{30}$ Dyck, 563.

${ }^{31}$ Cosin, Correspondence, 127. Contextually, Cosin is writing about the Christogram, which does not, as the Jesuit version, have a cross above the letters. He argues (possibly talking about the elongated omega above the letters) that the pattern is embroidered on "most pulpit clothes in London" with "no feare of poperie" due to the similar appearance of engraving of Jehovah in Bibles and service books.

${ }^{32}$ Two notable exceptions include Lancelot Andrewes's/Henry Isaacson's Institutiones Piae (London: 1630), where two women (holding an anchor and cross) pray towards the flaming heart, and Jeremy Taylor's The Worthy Communicant (London: 1667), where two angels pray toward the communion elements laid atop a railed-off altar. Taylor's Laudian ethos befits the typical portrait of Laudianism. See 188: "here we do not only here the words of Christ, but we obey them; we believe with the heart, and here we confesse with the mouth, and we act with the hand, and incline the head, and bow the knee, and give our heart in sacrifice: here we come to Christ, and Christ comes to us."

${ }^{33}$ See also Chapter Four's discussion of Herbert's "The Altar" which makes use of this Psalm. Richard Crashaw's "Flaming Heart" is tangentially related: the image at the heart of the poem is the Ecstasy of St. Teresa, but it is dedicated to the Countess of Denbigh, one of Henrietta Maria's ladies-in-waiting. Like Crashaw, she would later convert to Catholicism.

${ }^{34}$ Prynne's attacks against the IHS are not contained to Cosin alone. According to Graham Parry, The Arts of the Anglican Counter-Reformation: Glory, Laud and Honour, (Rochester, NY:

Boydell \& Brewer, 2006), 144, Prynne cited the Christogram usage as introducing Popery against Laud in his trial.

${ }^{35}$ See also Burton, A Tryall, sig. B1v, C1v, and C2r, where Burton refers to the usual badge of Jesuitical books.

${ }^{36}$ Parry, Arts of the Anglican Counter-Reformation, 115. He acknowledges that the mere presence of the IHS motif "always around suspicion of Catholic sympathies."

${ }^{37}$ See also sig. M4r, where Burton notes that Cosin bookends his Devotions with a cross (he ends with a prayer that includes Christ's blessed cross), which he sees as popish.

${ }^{38}$ Ryrie, Being Protestant, 148, citing Burton, sig. D3v-4r and E3r.

39 "IHS, n.". OED Online. September 2020. Oxford University Press.

${ }^{40}$ As acknowledged by Stanwood, 336, one of Cosin's "Devout Prayers" in the Matins, sig. G3v, draws heavily from Loyola's Spiritual Exercises in the "Contemplation for obtaining love" in the fourth week.

${ }^{41}$ This woodcut of Christ is replicated in Jeremy Taylor's A Collection of Offices or Forms of Prayer (London: 1657), which also assumes an ancient lineage for the formal prayers.

${ }^{42}$ For Green, see note 3 above. In addition to Stanwood's edition of Private Devotions, see Parry, Arts of the Anglican Counter-Reformation, 114-7.

${ }^{43}$ Immediately preceding this passage is a summary of Prynne's identified popish elements, including the cross, canonical hours, canonization of saints, prohibited times of marriage, laws and canon of the church, pictures of God, Son, and Holy Spirit, worshiping of Saints and images, Church Precepts, seven sacraments, venial sins, apostolical institution of Lent and fasting days, auricular confession to a priest, altars, penance, "Odoration" of the Host, Corporal presence, mediation of Angels, and prayers for the dead.

${ }^{44}$ Prynne is not wrong that there are strong verbal parallels in the material, at least from his sideby-side comparison, especially with The Ladies Primer (which has a few variants, possibly stemming from a 1534 translation of the primer) and Cardinal Bellarmine's Christian Doctrine (translated into English in 1604). See Prynne's note on 56: "I finde not the Creed nor the Lords Prayer thus divided into Articles and Petitions" in any "other Protesta[n]t Authors, but only in Popish Writers, out of whom no doubt they were transferred." 
${ }^{45}$ The critique of Laudian ceremony generally falls along these lines. While the Laudians provide reasons and rationales for the outward facing parts of religion, often based in inward thought and reflection, it is the veneer itself that attracts criticism.

${ }^{46}$ Burton, A Tryall, sig. G2v-3v, even puts Cosin's words side-by-side with the Catechism and Article 25, with the comment to "Note here the vast difference betweene the sincerity of our Church, and the egregious sophistry of this our author."

${ }^{47}$ Collection of Private Devotions, edited by Stanwood, 54.

${ }^{48}$ Cosin's margin cites Acts 8, John 20, 1 Timothy 4, Ephesians 5 and James 5, which variously promote baptism, laying of hands, marriage, and faithful living against false doctrine.

${ }^{49}$ See sig. B3v, which pairs the infeasibility of adhering to all the hours with the demands of regular penance and satisfaction: "Or otherwise you must be driven of necessitie either daily to goe to shrift for absolution, or to chawke up all your defects and failings for your general shrift: Wherein, and for which, such penance may be imposed upon you, as you shall hardly determine whither of the two is more grievous, to observe the rules for your devotion, or to satisfie for the penaltie."

${ }^{50}$ Andrewes himself was known to practice auricular confession. For aligning with Catholic practices, see Lee W. Gibbs, "Richard Hooker and Lancelot Andrewes on Priestly Absolution" in Richard Hooker and the Construction of Christian Community, edited Arthur Stephen McGrade, 261-274, (Tempe, AZ: Medieval \& Renaissance Texts \& Studies, 1997), especially 274.

${ }^{51} B C P$, sig. M8v-N[1]r and N5v.

${ }^{52}$ John Overall, Articles to be Enquired of in the Diocesse of Norwich (London: 1619), 8.

"Constitutions and Canons Ecclesiastical" Anglican.net (1604 Canons), https://www.anglican.net/doctrines/1604-canon-law/, (accessed February 10, 2021).

${ }^{53}$ For the priest/minister debate see: Brief Survay, 104; A Tryall, sig. A1r: "he had rather be a popish Priest, then a Minister of the better Testament." For scholarly views, see Parry, Arts of the Anglican Counter-Reformation, 2, or Milton, ed., Oxford History of Anglicanism, 63-82, esp. 71. ${ }^{54}$ Canon 6. Canon 4 condemns impugners of public worship. This is not to say that the puritans ignore Canon Law altogether. Burton only references the "Popes canon law," sig. F2v. Prynne refers more broadly to canon law, but never engages with the canons Cosin cites and generally refutes Cosin's canon law as being popish or nonexistent (of some primitive church that had no canon law).

55 "precept, n.". OED Online. September 2020. Oxford University Press. Cf. "canon, n.1". OED Online. September 2020. Oxford University Press..

${ }^{56}$ With the exception of Prynne's belief that festivals detract from Sabbath observation, which we will see in the discussion of the fourth commandment below. Burton, A Tryall, sig. E4r; Prynne Brief Survay, 15-17. Prynne condemns Cosin's promotion of ember days; see Stanley Fish, The Living Temple: George Herbert and Catechizing (Berkeley: University of California Press, 1978), 12, for a claim that Herbert wanted more ember day observances.

${ }^{57}$ Fasting was most prominent during Lent; while there are other fasts, most conflate fasting days with the Lenten season. See Stephen Hampton, "'Welcome Dear Feast of Lent': Rival Understandings of the Forty-day Fast in Early Stuart England," The Journal of Theological Studies 63.2 (2012): 608-48. For Cosin (who cites Bellarmine on fasting) and the puritans, see 630-33.

${ }^{58}$ Which is not to say that the others are not Laudian; the first commandment, sig. C2r, clarifies to worship God "With all inward devotion of our soules" and forbids "shar[ing] of his honour to Angels, or Saints, or any other Creature" yet such a distinction gets ignored with the calendar of saints. For sakes of space I gloss over the discussion of saints days, but Burton, sig. A1r, and Prynne, 34-5, condemn Cosin's inclusion, which at no points includes saintly invocation. Parry, "The Tradition," 46 notes that all of Cosin's saints are early medieval English saints - not Roman. Moreover, Cosin's "Of the Calendar, and the special use thereof in the Church of God," sig. A10r-11r, clarifies that the festivals and fasting days of the Church are for the "memories of 
such holy men and martyrs" and that, citing Augustine, "the chief ose of it in the Church ... is to preserve a solemn memory" which recognizes the "high benefits, which God, both my Himself, His Son, and His blessed Spirit, one undivided Trinity, hath bestowed upon mankind, for the founding and propagating of that Christian Faith and Religion."

${ }^{59}$ Perhaps an example of the difference a generation makes, Cosin's royalist reading of the fifth commandment (to obey and reverence the king's sovereign authority) escapes puritan commentary.

${ }^{60}$ Highly apropos is Cosin's ninth offender of the third commandment (not taking God's name in vain), sig. C5r: "They that contemne his Saints, that prophane his Temples, that slight his

Sacraments, that regard not his service, that use and speake of these, as of common things, where they have Gods marke upon them, being set apart and dedicated to the service of his most Holy and fearefull Name."

${ }^{61}$ Burton also argues against the use of "idols" as "false Gods" since the Douay translation of Exodus 20 leaves room for images; Burton questions whether the worship of angels and saints turns them into false gods. Cosin would probably agree with him on that account, but not of allowing images to be worshiped.

${ }^{62}$ Interestingly, Prynne continues to argue that Cosin aligns with "moderate Papists" as separated from "all Orthodoxe Protestant Authors." Though Cosin is "meerely Popish," Prynne admits a spectrum and range of beliefs, even within Catholicism.

${ }^{63}$ Davies, 178-9, discusses the disagreement over the Sabbath, even among Laudian clergy.

${ }^{64}$ Ryrie, Being Protestant, 214-224, explores the controversy, but on 214, notes that the dispute "hardens" in the 1640s, though it had been "flaring up regularly since the 1570s."

${ }^{65}$ Stanwood's commentary, in Cosin, 333ff. Worth repeating is Stanwood's citation, 336, of a prayer of Loyola that appears in the Matins, but most prayers have other traditional precedents less Jesuitical. See also Hanson, passim.

${ }^{66}$ Geoffrey Cuming, The Godly Order: Texts and Studies Relating to the book of Common Prayer, (London: Alcuin Club/SPCK, 1983), 124, traces Cosin's pre-Durham study of the various sources of the church's liturgy. As an aside he, 23-25, compares the English Daily Offices with sixteenth-century Lutheran practices.

${ }^{67}$ Ryrie, Being Protestant, 204.

${ }^{68}$ Arnold Hunt, "Featley [Fairclough], Daniel (1582-1645), Church of England clergyman and religious controversialist." Oxford Dictionary of National Biography. OUP: (23 Sep.

2004; accessed 11 Feb. 11, 2021), "Archbishop's Chaplain," paras. 1 and 3. Hunt provides examples that Featley licensed puritan texts with only cutting a chapter that likened the episcopacy to papacy and adjusted minorly a chapter critiquing the Church of England's ceremonies. In 1625, Featley received kingly reprimand for printing two puritan works, which may have ended Abbott's patronage of him. Despite having his Clava Mystica censored by Laud (who, according to Prynne, removed passages attacking papists, Jesuits and Arminians), Featley was appointed royal chaplain in the 1630s. He was the only "leading Episcopalian" named to the Westminster Assembly and would later get in trouble for encouraging ceremonial observance of kneeling at the name of Jesus and standing up for the Gloria Patri at Lambeth in the 1640s.

${ }^{69}$ Respectively Christian ABC, 647, and Print and Protestantism, 269. Lambert, 52, notes that Featley came into "serious trouble" for his licensing of texts in 1624.

${ }^{70}$ Hunt, "Featley," "Civil War," paras. 2-4. See also Peter Abraham, "The Use of Hierarchy in the Post-Reformation Church: Laudian Altar Policy in the Diocese of Winchester," Anglican and Episcopal History 72.2 (June 2003): 188-89.

${ }^{71} O D N B$, "Family piety," para. 2.

${ }^{72}$ Perhaps because of his use of the $B C P$, Cynthia Garrett, "The Rhetoric of Supplication: Prayer Theory in Seventeenth-Century England," Renaissance Quarterly 46.2 (Summer 1993): 339, calls Featley the author of an "Anglican prayer manual" along with Andrewes (Institutiones Piae). $(328-57)$ 
${ }^{73}$ Salazar, 183, suggests this dedication is to "procure anti-Calvinist favour" and identifies the Duchess as the sister-in-law to the Countess of Denbigh.

${ }^{74}$ Featley's dedication to her is sig. S4r. The conference with the Jesuits took place in 1621 , which Featley wrote about in 1623 and 1624. See Bernard Capp, "The Religious Marketplace: Public Disputations in Civil War and Interregnum England," The English Historical Review 129.536 (February 2014): 51-52, or Salazar, 186.

75 This outline is taken from sig. a2v. The three parts fall under the "Garden of spirituall flowers" and is met by the "nurserie" of 52 plants - the catechism which contains rules and actions Christians should take. See also Featley's The Summe of Saving Knowledge: Delivered in a Catechisme, consisting of fifty two Sections answerable to the Sabbaths throughout the Yeere (London: 1626), 2-3, which calls "Hearing the Word preached. Receiving the Sacraments. And Publique and private Prayer" the three "Special meanes of salvation."

${ }^{76}$ The admonition has no exact scriptural referent, but perhaps conflates Matthew 26:31/Mark 14:38 (KJV: Watch and pray, that ye not enter into temptation: The spirit indeed is willing, but the flesh is weak) with Luke 21:36 (Watch ye therefore, and pray always, that ye may be accounted worthy to escape all these things that shall come to pass, and to stand before the Son of Man). The latter fits tonally with the ethos of the Revelations allusion.

${ }^{77}$ Respectively, the other scripture references are Acts 2:3 (Pentecost), Acts 1:11 (Ascension), Matthew 28:6 (Easter), Luke 2:11 (angels to the shepherds), and Matthew 2:9 (Wise Men). Salazar, 106-7, says the woodcut replaces the annunciation with other images of handmaidens and devotion.

${ }^{78}$ See also 64: "let the private, voluntary always give way to the publike, necessary duty."

${ }^{79}$ Private Devotions, sig. A6r-9v.

${ }^{80}$ Ryrie, Being Protestant, 172. See also the section on Thomas Tymme in Chapter Three, below.

${ }^{81}$ Cf. Herbert's "Business" - "Who in heart not ever kneels, / Neither sin nor Savior feels."

82 This occurs after a quotation of Phillipians 2:10-12.

${ }^{83}$ Ancilla, 110, in the Practice of Private Devotion, both ordinary and extraordinary, Featley writes "I intend ... to expresse in the matter pious affection." Cf. Herbert's "Jordan" (1), Featley, 110-11, writes: "in the forme Scripture phrase and elocution. For it seemeth to mee most agreeable to speak to God, as neere as we can, in the same language he speakes to us, which is the sanctified language of the Bible. . . affected humane eloquence (consisting in streined conceits of wit, \& swelling words of vanitie) . . . puffeth up those that use it." As with gesture, the words should be sincere and appropriate to the occasion.

${ }^{84}$ Brief Survay, 16, which cites pages 526 and 540-6 of Ancilla Pietatis, Featley's discourse on fasting, the Roman tradition, and an embedded mini-catechism on the nature of fasts. Aside from doing more explicitly to distance the Protestant practice from Catholic, Featley's views of fasting actually align with Cosin's, so the citation seems to be invoke a partisan-ethos stemming from Featley's licensing of puritan texts.

${ }^{85}$ A notion repeated later, Ancilla, 416: "the Church of England in her rubricks wrote after the copy set by the antient Primitive Church, and other reformed Churches, [which] concurre either in pracitise or judgement."

${ }^{86}$ See Cosin's description of the Church Calendar, Private Devotions, sig. A10r-12v.

${ }^{87}$ See also the epistle to the Countess of Denbigh, sig. S4v, where feasts represent "what Christ hath done for you" and fasts admonish "what Christ hath suffered for you" and directs, sig. S6v, to "feast to him" [God/Christ].

${ }^{88} 409$ is misprinted "49." Featley, 411, goes into detail saying that on Mary's day, "wee honour Christ whom she bare" on St. John the Baptist, "Christ whose forerunner he was" and so on, for martyrs, apostles, and evangelists. In line with Hooker, he cites Augustine's City of God saying that "Wee erect no Altar, we dedicate no Temple" or feast to anyone but God.

${ }^{89}$ Featley also cites, 414-15, the example of Purim where the synagogue created a feast without "special warrant or order from God" to commemorate temporal blessings and deliverances, and 
he applies that to "the whole company of Gods elect" - which seems to be a tacit statement in support of James's deliverance holidays.

${ }^{90}$ Andrewes's XCVI Sermons was published in 1629, which Peter McCullough argues serves as a Laudian manifesto, especially with its unique arrangement by festival day. See "Making Dead Men Speak," 410-11.

${ }^{91}$ This claim is in direct opposition to Doerksen, Conforming to the Word, 38, who claims that Hooker had limited influence in the seventeenth century. As Hampton, 637, notes, Cosin, Featley, and Prynne all made explicit reference to Book V of the Ecclesisatical Politie in their writings on the fast.

${ }^{92}$ In addition to what is cited above, see, e. g., Burton, Tryall, D3r and I2r-v, for references to Jewish ceremonies.

${ }^{93}$ Appropriate levels of superstition has echoes to Andrewes's 1614 Easter sermon, XCVI 477, that removing all superstition creates irreligious behavior - all worship (including the hearing of sermons) has inherent levels of superstition. See also Ancilla, 536, on the fast as duty to punish the flesh for the sins: "And if this bee superstition, what is Religion?"

${ }^{94}$ Lawes, V.LXXII.1.407.

${ }^{95}$ Ancilla, 507, outlines the "present practice" to be weekly on Fridays, monthly on the eves of holidays, quarterly in Ember Weeks, and yearly at Lent. For Prynne's objections to Ember Weeks, see Brief Survay, 10-11 and 16.

96 "Dear Feast," passim.

${ }^{97}$ Ancilla, 515-16. Featley follows this with a mirrored list of abuses of fasting, 517-19, for those who abstain from one meat and glut on another, who fast for too long, or, who, "as Papists doe," fast for merit.

${ }^{98}$ The original essay appears in the second edition on pp. 543-46 as a supplement to the second catechism question on whether the fast is "meerely civill or Religious."

${ }^{99}$ Ancilla, 4, attributes a critique to Leo that "He that is not more religious in Lent then at other times hath no religio[n] at all." In context, Featley discusses sincerity in devotion and includes this as part of the rational to make devotions for the entire year.

${ }^{100}$ Ancilla, 527-40; 537-8 contains the Swiss and German examples. See also, 535-6: "Lent is no late Popish tradition, but a most ancient Christian observation of longer standing by many hundreth of yeers then the first stone in the tower of the Romish Babel."

${ }^{101}$ Ancilla, 541-51.

${ }^{102}$ For predestination, e.g., see Summe of Saving Knowledge, 8.

${ }^{103}$ While Featley does not use the word motherly or matron, he does cite the Handmaid and Mistress, and personifies Devotion as female. He follows Devotion's duty to catechize with "every godly Parent, Tutor, and Master of a Family," which is not inherently gendered as catechizing fell to both parents.

${ }^{104} \mathrm{Cf}$. Tymme and Bayly, below. It may be important to highlight, as regards gesture, the duties of superiors and kings, who, Summe, 42-43, are to "make wholesome and godly Lawes and Edicts for the Establishing of Religion" and to call ecclesiastical and civil assemblies "for the better ordering of the affaires of Church." Aside from where he writes, 44, "mak[ing] supplication" and "submit[ting] themselves to" kingly power, Featley makes no explicit command for them to humble themselves and kneel to their king. 
Chapter Three: Laudianism in Private Devotionals, 1612-1631

In the previous chapters, we saw confessional identity at work in genres that easily give way to polemical and political battlegrounds, whether in sermons delivered at court in times of a national project or in puritan polemics responding to perceived cryptoCatholic propaganda. This chapter seeks to examine a set of private devotions, both obscure and popular, that guide personal piety for individuals and families at home and at church. These texts, while still predominantly published in London and authored by university-educated priests, were written by comparatively less elite authors than in the preceding chapters, by those who did not attain high ecclesiastical office. ${ }^{1}$ Because few recent scholars have focused broadly on private devotions as a genre unto themselves, Ian Green's pronouncement that the basic didactic nature of devotional texts preclude polemical efforts remains relatively unchallenged. This chapter works against the notion that confessional arguments only occurred in "elite" settings; the debates in the bishops' pulpits and devotionals can also be found in more common texts, as Paula McQuade has demonstrated with the case of Dorothy Burch in Strode..$^{2}$ It is my intention in this chapter both to show that devotional texts were indeed a battleground for contested worship practices and that the ceremonial and liturgical conformity endorsed by Andrewes, Buckeridge, and Cosin was promoted by less prominent churchmen and found private audiences. Common topics will include gesture, the use of set prayers, the relationship between public and private prayer, the emphasis on avoiding presumption or familiarity, and the pitting of prayer against sermons. ${ }^{3}$ 
This chapter perhaps has the most bearing on my thesis that Laudianism is a broad, moderate ideology that extends beyond issues of the altar controversy, predestination, and a king-led episcopacy. Although these devotionals do not receive uniform widespread scholarly attention, these texts are, when discussed, usually painted under some type of Calvinist categorization due to their endorsement of predestination or preference for table or minister over altar or priest. As noted in the Introduction, many of these binary debates post-date the publication of these texts. Instead of focusing on those issues alone, this chapter looks at other theological issues and makes use of biography to challenge the assumption that all Laudians were anti-Calvinist or anti-puritan. For the sake of consistency and convenience, most biographical references stem from the Oxford Dictionary of National Biography or the classifications found in Green's or Ryrie's catalogues of English devotional texts. Though the label of "conforming Calvinist" or "conforming puritan" to these ministers may be relevant, its use broadens the Calvinist influence on English Protestantism while limiting the Laudian influence, which is marked not by some unique brand of ceremonial conformity but the shared tradition of the established Church.

Although this chapter will make comparative gestures to other chapters, it is important to note that these devotionals also stand by themselves. Perhaps the most important element to note in these devotionals is their explicit didactic nature. Compared to sermons, which share an emphasis in the audience's edification, private devotions tend to offer a more step-by-step level of instruction that - aside from the glaring exception of occasional prayers - are less bound to specific occasions. As seen in the previous chapter, the polemical fodder of Cosin's and Featley's texts was not so much the listing of set 
prayers but the explanations and rationales for the various practices. ${ }^{4}$ The four sample texts chosen for this chapter contain similar material. In addition to displaying Laudian elements in their formal and instructional content, these texts were first published between 1612 and 1635 . This selectivity means that several exemplary texts were left out, whether for their Laudianism, as in works of Isaacson, Andrewes, Laud or Allestree, or for their popularity, as with the works of Sparke, Norden, or Dent. ${ }^{5}$ While all of these texts fall under the broad generic umbrella of private devotional, each fits different subgenres. Thomas Tymme's Chariot of Devotion (1618) is part treatise on proper devotional behavior and part dialogue. Lewis Bayly's Practise of Pietie (c. 1612) is manual of pious practices for all occasions, similar to Featley's Ancilla Pietatis but more comprehensive. Charles Herle's Contemplations and Devotions on ... our blessed Saviors death and Passion (1631) contains a number of scriptural meditations. Henry Tozer's Directions for a Godly Life (1628) is similar to Bayly's text, except it lacks models and set devotions. It consists solely of written prescriptions for a Godly life, including sacramental observation. Many of the prefaces or title pages allege that the works originated for the private use of the author but were published for public use; similar anecdotes appear in the prefaces to Featley's and Cosin's devotionals, though they were also intended for courtly use. First up is Tymme's A Chariot of Devotion, a treatise written by the minister of a small Suffolk parish called Hasketon. Tymme argues that sermon-centered piety had diminished the role of prayer in Christian religious life. 


\section{Thomas Tymme's 1618 A Chariot of Devotion}

Thomas Tymme's biography paints him as a moderate preacher content to live in Hasketon, where he found success publishing translations of theological works and devotionals. Because the argument of his Chariot of Devotion mirrors the concerns of sermons preached at court in 1618 , he provides a good corollary to Andrewes. ${ }^{6}$ Green characterizes Tymme as having Calvinist tendencies, but avoids classifying him as such due to a perceived looseness in disregarding predestination and suggests his devotional works have a semi-Pelagian influence of imitating Christ. ${ }^{7}$ Tymme's $O D N B$ biographer

avoids classifying Tymme at all, only writing that his turn-of-the-century devotions found a widespread audience; Ryrie, who also argues for a broader understanding of English Protestantism, cites the introduction of Chariot to show not that Tymme was expressing “an 'anti-puritan' view” but a viewpoint "that puritans were reluctant to say . . . in public" (Tymme's Wikipedia page, on the other hand, says he "combined Puritan views" on adultery with support for alchemy and science). ${ }^{8}$ Tymme's early works embody the Protestantism of Cranmer and display strong anti-Catholic rhetoric, maligning the pope's influence on the "universall Church." ${ }^{\prime 9}$ While praising Elizabeth's leadership in protecting England and her church in the 1580s, Tymme lays out a statement of religious practice that aligns with Laudian descriptions of worship: Tymme writes for the constancy of religion, saying "let us principally be constant in his worship, service, and feare, in such wise that with those zealous Israelites ... we would rather venture to lose our lives, then suffer Religion to bee changed" and states simply the duty of a Christian to "Serve him with feare, worship him, and call upon his holy name."10 These keywords - worship, 
service, fear - have often been found in Laudian calls for ceremonial worship that blends inner and outer devotion and Tymme places them in the Protestant tradition.

Because Tymme published A Chariot of Devotion in 1618 one could claim that the text aligns with what Peter McCullough has identified as a chronological "Jacobean turn" towards Laudianism but dismiss its importance as it only saw one edition. ${ }^{11}$ However, Tymme's most famous work, his 1605 Silver Watch-bell that went through nine editions by 1618 (and 19 by 1660), supports a wide range of theological ideas all encapsulated under English Protestantism. Green categorizes this manual on godly dying in the vein of continental Catholics like Thomas a Kempis rather than Calvinists like Beza or Perkins. ${ }^{12}$ One example from the Silver Watch-bell shows a hesitancy to endorse predestination. The fifth chapter concerns itself with "the small number of them that shall be saved." In it, Tymme subtly denies double predestination, the belief that God predestines both the elect and the damned: "To this objection [that God damns so many] it may thus bee answered: First that mercy may bee saide to exceede his justice, for that our whole salvation is of his mercy, and our damnation of our selves, as from the first and principall cause thereof' (103). While Tymme does not elaborate here on how salvation via God's mercy works, he relegates damnation to mankind, whose sins come from their own willful ignorance or disobedience - something present in those who do not suffer themselves to bow their heads in humility before holiness (122). Writing at length on superstition and idolatry in the attached tract on communion, Tymme identifies the superstitious church to be Roman. The preacher's description of proper worship seems copacetic to the proto-Laudian prescriptions we have already seen. He writes:

the Pope and his doctrine is contrary to our Lord Jesus Christ and to his holy Gospel: it behooveth all true faithfull people to withdraw themselves wholy from 
Poperie, and cast off without delay the yoke of that Romish Antichrist, that they may give themselves wholy to the service of this Saviour and Redeemer Jesus Christ. But if so be that the $\mathrm{Co}[\mathrm{m}]$ munion that we have with the sonne of God, and the promises of the heavenly Father, cannot intice \& perswade vs to yeeld our selves wholy to God, to put our trust in him onely, to serve and worship him onely, according to his will, but that we wil yet cleaue unto Antichrist \& his servants \& Ministers. (243)

Tymme argues that communion is a place where Christians can dedicate themselves wholly to the (holy) service of God and not idolatry or false images of the deity, which is what Andrewes promoted in his 1617 Gunpowder Plot Sermon and what Cosin, in the next decade, would promote in his explication on the Ten Commandments. Likewise, Tymme mirrors the belief in matching inward reflection with outward actions: while dismissing those who pharisaically seek out public prayer for the appearance of it in hypocrisy, Tymme argues that, in praising God, "here must be a consent and mutuall agreement between our inward affections and our tongues" (261). This mirroring of Laudian viewpoints suggests that Tymme's conformity was not simply a byproduct of his later years but consistent across his oeuvre.

A Chariot of Devotion, a self-described treatise on devotion that seeks to elevate the status of prayer over sermon-hearing, complements the other Laudian works in this project, though it displays less of a concern for sacramental devotion. The publication's form speaks to its didactic purposes. The first half of the text is a treatise with chapters on blind devotion, the use and manner of prayer, and a defense of common and public prayer. The second half shifts modes to a dialogue between Preaching and Prayer (Predication and Oration) that ultimately argues for moderation in blend the two together, rather than replacing one for the other. While the formal elements might suggest a more polemical genre, Richards and Schurink argue that "dialogues offer a model for readers' 
responses to the text," so the dialogue for prayer, in a way, functions the same didactic mode as set prayers. ${ }^{13}$ Tymme's approach aligns with what Fincham has identified as a "custodian of order" (juxtaposed against the homiletic piety of "preaching pastors," in which he often cites Featley's sermons as exempla), manifested in Tymme's focus on the "proper place and order " in the "service and worship of God" (Chariot sig. A3v). ${ }^{14}$ This work connects to each chapter of this project: I have touched upon the 1618 similarities in Chapter One; the manual defends set formal prayers, but, unlike Featley and Cosin, does not include any prayers. Two couplets from Herbert sum Tymme's argument. In "The Church-porch," the proverbial poem of preparation to enter into the church or temple, Herbert writes “Though private prayer be a brave designe, / Yet publick hath more promises, more love" and "Resort to sermons, but to prayers most: Praying's the end of preaching." 15 The thread between all of these is that Laudian-style worship encourages active participation and service, which occurs in this case through thoughtfully considered and enacted prayer. Three elements of Tymme's treatise mark it as sympathetic to Laudian causes: conforming to public prayer, blending inward humility and compunction with outward gesture while praying, and reducing the perceived emphasis on sermon-centered piety.

For Tymme, prayer functions as true worship, and the English Church's common prayer derives from proper and orthodox tradition for individual practice. The ancient church, naturally, serves as the example. In the chapter "Concerning the use of prayer," Tymme writes: "This service and worship of God, from the beginning of the World ... was more publique in the dayes of Sheth and Enosh. Heere we must understand that prayer is to be used privately, and publiquely ... For it consisteth in words, meditation, 
and invocation" (8-9). Both private (closet) and public (common) prayer serve purposes for the believer's worship practices and edification. He argues that private prayer is a more recent innovation that should not supersede common prayer but exist in tandem with it, to be performed in all locations. ${ }^{16}$ In the chapter "concerning publique Common Prayer," Tymme argues that common and set forms of prayer were "never contradicted till our new Donatists and the Brownistes, sprung up" (35). ${ }^{17}$ He elaborates saying, "The contradiction of a set forme of prayer doth not only crosse the practice of Christ ... but also the Apostles practice, who went up to publique prayer" (35). For support, Tymme cites the Book of Acts and enumerates five reasons why those who pray extemporaneously fall short of true worship in advancing vain fancies. His conclusion is brief: "printed prayers are necessary" to prevent vain "inconveniences" (35-37). More biblical examples follow to support the notions that priests should set aside time for prayer and congregants demonstrate their faith when the whole church prayers together. Absent from this defense are quotations from the $B C P$. Despite neglecting the opportunity for prayerbook conformity, Tymme's argument seems to target those puritans who eschew forms altogether, especially in public settings. ${ }^{18}$ Tymme confessionalizes this issue when addressing the role of pastors. Though the initial statement is "God hath ordained his Priest and Ministers to execute" public prayer (37), Tymme repeats the epithet priest throughout the rest of the chapter, the sacrificial character of which is supported when he maintains that "this prayer of the whole Church is a sacrifice to God" (41). Though minister-priest and extemporaneous-set prayer debates may not harden until the 1640s, Tymme's 1618 treatise shows that the issues were present earlier, and he aligns with the Laudian viewpoint. 
If the title-page description of "Preached before the King at Whitehall" and being printed by the king's printers or authority gives Laudian sermons a courtly ethos, then the title page description of Tymme as a "Minister at Hasketon in Suffolke" and the dedicatory epistle to a Suffolk noble family localizes Tymme's argument away from the London court. While he never actually defines his audience - the epistle seems a fairly generic rhetorical gesture for patronage - or purpose in writing, Tymme's epistle states his thesis of combatting prayer against the centrality of sermon-hearing. Tymme begins this argument through defining the zeal of one who was carried to heaven by chariot, Elijah, who was "of the highest nature and most divine... [sic] suted well with the zealous and fervent spirit of Eliah in the service and worship of God," that contextualizes his concern for proper worship (sig. A2v). Tymme's complaint about the lack of proper worship would not be out of place in the Whitehall pulpit. He follows this exemplar with a lament about those who hear sermons and ignore the service of common prayer: "Notwithstanding, the loftie nature of this Divine worship, there are some in this age, who thinke that the chiefe part of Gods worship, consisteth in a bare and idle hearing of daily Sermons, contemning in comparison thereof, publique, common, \& joint praier, much forgetting this sentence of Salomons Preacher there is a time for every thing" (A3r). Tymme's polemical target is the ambiguous "some" who engage in idle sermonhearing. How fitting, then, that the epistle's closing line is a quotation of James 1:22 (75: "See then that ye be dooers of the word, and not hearers onely, deceiving your selves"), which, to return to Andrewes, was a sermon-text for a 1607 sermon on the same theme. ${ }^{19}$ As we will soon see, the idleness stems from hearing that does not stir the hearer to a follow-up action, whether in meditation, prayer, worship, or other action. 
Tymme elaborates this viewpoint in his critique of sermon-gadders, those who make frequent sport of hearing daily sermons. This condemnation predicts the dialogue of those who should do more once they have heard the preacher's words. Ultimately, Tymme argues, sermon-gadders tend to lack conviction: "when men have attained a competent knowledge of the way and meanes to salvation, they ought to be stayed therein, and so then heare lesse, and pray more, and not to shew themselves Nonproficients, ever learning, and never in practice" (sig. A3r). Careful not just to antagonize sermon-gadders and avoid overt polemicizing (this is the passage Ryrie cited when he said Tymme was expressing what puritans would hesitate to make public), Tymme balances this accusation, with what may be the most explicit tie to the classification as a custodian of order. He writes, "In the service and worship of God, every thing ought to have his proper place and order: a consequence so pleasing to God, that he vouchsafeth to be called the God of Order, and not of confusion. All prayer and no preaching, is the heresie of the Euchites: and all hearing and no common prayer, is a sprout as bad an heresie, if not worse" (sig. A3v). By adhering to God's preference for order and varied practice, the Christian avoids heresies, whether resembling the Euchites, who privileged prayer as the exclusive means of grace and forewent all other parts of worship, or those who, as first cited by Chrysostom, came to the church for the sermon but left before the service and actual worship began. Tymme's defense of worship and public prayer tends to target those controversial opinions stereotypically held by puritans. As such, Tymme's argument is one that moderates the overzealous private worship with the responsibilities and duties of public. 
Where Tymme perhaps is most Laudian (and controversial) is when he promotes gesture as a reflection of humility. This occurs most prominently in the third chapter, "Concerning the manner how we ought to pray," which includes kneeling during prayer. Ryrie maintains that kneeling during prayer is commonplace and uncontroversial, except when applied to communion. ${ }^{20}$ While Tymme does not write here of communion, he does spend a lot of time arguing an allegedly non-controversial opinion, and his argumentation resembles the Avant-Garde Conformist position laid out by Buckeridge in his 1618 sermon and tract on kneeling at communion. Tymme believes that true prayer comes from a "humble and contrite heart" and that "humilitie is the foundation of all vertues" which informs the Christian duty to pray $(8-9,14)$. So long as the Christian bases his orations in humility, Tymme is fairly flexible in what form gesture takes, with one exception: "As this humilitie is seated in the minde of the godly; so also it is to be shewed in outward gesture when we prayer: that is, eyther as a servant, standing; or else an obedient sonne, kneeling; or as a vassal and humble suppliant, prostrating: and never (upon necessity) sitting" (16). It is tempting to assume that this viewpoint would also apply to communion, but the important element to take away from this that Tymme is against Christian presumption, where sitting suggests the supplicant is approaching the deity as an equal. In this sense, and according to Ryrie's assessment that puritans tended toward homeliness and familiarity in praying to God, Tymme's position approaches the Laudian even without considering the sacrament. ${ }^{21}$ Such familiarity is unbecoming before God. He even makes a similar, if not identical, point to Buckeridge's about those who kneel openly in their daily lives, but selectively before God: "Before a potshard and sinfull man, we bend and bow, crowch and kneele; and are submissive in obeisance to a 
chaire of state, thinking all we can doe this way too little: But to the most supreame divine Majestie, our daily behaviour sheweth we thinke all too much" (16). ${ }^{22}$ Lastly, this position stems from the same biblical proof as the sermons of Buckeridge and Andrewes, the Venite, misidentified in the margin as Psalm 99: "The Prophet David thought this humiliation fit, and therefore doth not only adore the Majesty of God himselfe, but also stirreth up others to do the like with him saying: $O$ come let us worship and fall downe, and kneele before the Lord our marker" (16). Though he elsewhere makes the comment that common prayer is a vessel to join minister and parishioner together in worship, Tymme does not comment on the Psalm's use in the liturgy, probably due to the emphasis on the act of prayer and not the applications of prayer during (corporate) worship.

Because gesture stems from humility, it should be unsurprising that Tymme blends the outward gesture with signs of internal piety. Tymme, like Buckeridge, rebuffs potential counterarguments that emphasize internal shows of devotion alone. He writes: "But some will say, it is sufficient that I worship the Lord with my heart. I answere it is fit we so do, but more is required. . . in regard of this his excellent greatnesse, and of our vilenesse \& misery, we stand bound to render to him all the worship which may be performed by the whole man body \& soule, heart, mind and strength" (16-17). Kate Narveson pairs this quotation of Tymme with George Downame, a Laudian priest who published in 1640s, writing about using the tongue and voice as "outward things" to aid one's prayer. ${ }^{23}$ Like Buckeridge turning the Venite exultemus into venite humiliationem, Tymme frames "outward humiliation" as a device that both shows inner compunction and thanksgiving for Christian salvation in a manner that reinforces the hierarchy between 
human depravity and divine majesty. He expresses this through a question that he answers showing the fullness of both humility and devotion: "If this outward humiliation, prevailed thus far with God [so that he deferred intended vengeance], how much more will the humbling of the whole Man, body and soule please him. . . he will have the soule, and he will have the body also: And for this cause the Apostle willeth men to offer up their bodies" (17-18). This quotation ends with a citation of Romans 12, where in the first verse Paul exhorts his readers to give up their bodies as a holy "living sacrifice" in service to God. ${ }^{24}$ While kneeling is a sign of thankfulness for salvation, the physicality is not an act of individual arrogance, but of submission and humility. For Tymme, heartdevotion should have other physical manifestations: "Our prayers ought to us so inward that sobbing sights should proceede from a pensive heart ... Prayer with teares, is the more effectual" (22-23). If there is a hierarchy at play between inner and outer, then inward reflection and devotion still comes first; it is the outward showings that make it more effectual, according to Tymme's rationale. One last point that connects this to the 1618 sermons is that Tymme invokes the metaphor of a Christian servant, which, as a Laudian motif, reinforces inner humility against external superstition. Because many ask their servants to spend their whole days in work and employment, so too should Christians "do our faithfull service to God our Lord without wearinesse or grudging, all the dayes of our life" (28). ${ }^{25}$ Prayer, part of the worship of God, stems from service, so naturally the arguments about gesture from service apply equally to private and public (liturgical) prayer.

Nowhere is the call to moderation so apparent in A Chariot of Devotion than in the second half, when the text changes modes and becomes a dialogue in which Oration 
(prayer) submits Praedication (sermons) to a line of questioning. While Praedication often voices relevant counterarguments and questions, Oration seems to be the voice of reason. Tymme concludes the dialogue with the familiar Pauline ceremonial defense: "let all things be done (saith the Apostle) in decencie and order. Let preaching have her due time, and let not prayers be put out of place. And let both preaching and prayer shew their effects in al piety and Christian life. For what is the ende of Preaching, but the practice of pietie" (70-71). This quotation, like much of Tymme's work, relates to other chapters. Herbert maintains the "end of preaching" should be "praying," and Tymme's subsequent emphasis on the "old practice of devotion" aligns with Andrewes's and Cosin's positioning on holy works. ${ }^{26}$ All of them would likely agree with Tymme's assessment that "fasting, Prayer, and Almes . . consort together in a Christian harmony" where "the soule of prayer, is fasting" (71). All of these come together in the practice of piety in private and public worship. However, this assessment is culmination of the debate. The dialogue begins with Oration complaining to Praedication that certain individuals behave "as if all Religion, devotion \& pietie, consisted only in you." He further confesses that "bare reading is not so profitable for the common people, as is the expounding, the deviding, and the application of the same" (42-43). It is not the sermons that are bad for the auditor, but that the listeners are idle. In order for sermons to edify, the listener must apply the praedication: "For Preaching, properly is an expounding, and an applying of the written word by the voice of the Minister, to the instruction and edification of the hearers" (43). Hearing, then, is not preaching. ${ }^{27}$ Moderation and order in worship are what hold together the edifying value of practicing devotion: "For I hold it not fit, that prayer should extinguish all other parts of Gods worship and service, as sometime did the 
Messalians and the Euchitae. Neither would I that preaching should shoulder prayer out of the Church ... there is no reason that time should so intrude the one, that the other should lose her proper place" (48). ${ }^{28}$ Preaching and prayer, then, should not compete with each other but coexist. The problem arises when one privileges sermons over prayer, especially since sermons have a stronger potential for idleness - a similar argument made against set prayers, which allow for vain or idle repetitions.

As might be gleaned from his references to certain heretical sects, not all of Tymme's argument against sermon-hearing is scriptural, so his methodology aligns with Spinks's description of the "Patristic Reformed Churchmen." A prominent patristic authority is Chrysostom, whom Tymme quotes to show that the elder also complained in his writings that followers "were fervent to heare his Sermons, but cold in devotion and prayer." Tymme continues with the anecdote that Andrewes cited in his 1617 Gunpowder Plot Sermon, where "The fashion is now, to aske if there be a Sermon: if there be none, then either they come not at all, or nothing so cheerfully as they ought. For if there be no Sermon, their devotion is cold" (49). ${ }^{29}$ He then turns to Augustine to make another argument that moderation joins preaching, prayer, preacher, and audience together:

Preaching is a kind of invocating, yet not of the name of God: but rather an invocating and calling upon the people. . In prayer both Priest and people must joine together: but in preaching not so ... Prayer is the proper and direct worship of God, and (Except the sacrifice of obedience) the only continuall sacrifice that ought to be ... but Preaching ought not to be continuall. . . But the Sacraments may be truly ministred without a Sermon. (49-50)

For a preacher urging common prayer, his rationale that prayer joins the minister or priest with the layperson seems fitting.

All in all, Tymme fears a new heresy and seeks to avoid that through the elevation of prayer and its proper (and gestural) practice. True and correct devotion were Tymme's 
goals from the outset, so rather than seek to swing from one extremity in worship to the other, Tymme wants reform in current practices that are amenable to those who refuse to kneel and those who refuse to sit. For Tymme, like others making arguments in favor of gesture, worship is not about the individual, but the deity that receives the adoration from the individual. Because Tymme maintains that the end of preaching is the practice of piety, it is fitting that we turn from this single-edition work to one of the most popular devotions of the century, Lewis Bayly's Practise of Pietie, a comprehensive compendium of Christian behavior on how to act in manner pleasing to God. From Tymme, who had occasional Calvinist tendences, we move to someone categorized in a list of "unmistakable puritans." 30

\section{Lewis Bayly's 1612 The Practise of Pietie}

Because his biography makes him out to be a ceremonial puritan, Lewis Bayly makes for an interesting case study for this project. ${ }^{31}$ The Practise of Pietie: Directing a Christian how to walke that he may please God was one of the most popular and comprehensive devotion manuals of the seventeenth century. Originally published around 1612, Bayly's lengthy work went through more than 57 editions by $1728 .{ }^{32}$ By 1612 , Bayly held some minor ecclesiastical offices but it was not until after the publication of Practise of Piety that he would earn his DD (1613) and become Bishop of Bangor (1614). The $O D N B$ suggests his "quarrelsome nature" prevented further favor, so his biography lacks the royalist verve of the Avant-Garde Conformists. The $O D N B$ 's summary of 
Bayly's belief show the nuances of his Protestant beliefs, which, on theological lines, are similar to Featley's:

His standpoint was that of a conformist Calvinist, having emphases in common with puritanism, but also a respect for the authority of the church. While believing firmly in predestination to salvation and to damnation, he produced many biblical instances of God's mercy to the repentant. A strict sabbatarian, he commended almsgiving and condemned time wasted at stage plays and the bad examples set by some of the greatest in society, but he also supported private confession and conformity to outward rites and ceremonies. ${ }^{33}$

Similarly, Green's assessment of Bayly as a "moderate puritan prelate" is fair, but Green cautions that Bayly "was not a typical puritan and his handbook does not sit altogether comfortably in any one camp" due to him gaining royal favor (perhaps due to his support of the Gowry and Gunpowder feast-days), running afoul of the Privy Council, all while conforming to the established church and its various ceremonies despite hating playgoing distractions. Green also includes Bayly in a list of devotional writers, with Tymme, who do not meet the standards of the period's "high Calvinism." ${ }^{34}$ In both these categorizations, it is his belief in predestination that aligns him with Calvinism, his antistagecraft with puritanism, and his ceremonial conformity that avoids presumption with Laudianism. His one-size-fits-all manual encapsulated those wide-ranging beliefs, which made it attractive to all English Protestants, puritan and anti-Calvinist alike, though Veith notes the work "became the property of the 'Puritans' after the Restoration." 35 For my purposes, Bayly's work is important because of it advocates for humility in gesture, against presumption, how to act in church and the service (including proper behavior during the sermon that avoids passivity), and how to pray in church and at home. ${ }^{36}$ As was appropriate with Cosin, my analysis of the Practise of Piety begins with the frontispiece, a visual aid illuminating the power of prayer. ${ }^{37}$ Of all the frontispieces in 
this project, this is the earliest. Though, as Dyck has argued, several of the altar and name-of-God images were preceded by the $1611 \mathrm{KJV}$ frontispieces. ${ }^{38}$ The engraving has three levels, from top to bottom: a pious man prays to God, an hourglass and a watching maiden frame the words of the title, and the bottom depicts Joshua's battle against the Amalekites. The top-third contains the most familiar imagery, as if it conforms to what the King's Printing House authorized with the printing of the KJV. Atop a three-tiered dais with the words faith, hope, and charity embedded on each level, an individual, with the words "Pious man" on his cloak, faces away from a reading table, toward an altar with a flaming heart with the word "pray," his head raised toward a cloud of faces (perhaps angels or saints) and the Tetragrammaton. ${ }^{39}$ Between them are the words of Psalm 51, “A broken heart o lord despise not." Here is an image consistent with the Laudian images of other frontispieces (or, is consistent with the image printed by royal authority that would later be appropriated by Cosin and the Laudians). It is not, however, an endorsement of a Eucharistic altar. This work predates much of the altar/table controversy of the Lord's Supper that begins in the 1630s, and Bayly mostly refers to the "Lord's Table" when talking about communion. All of his references to an "altar" are variations of offering a contrite heart as sacrifice, through prayer. ${ }^{40}$

The rest of the frontispiece contains less typical imagery but buttresses the importance of praying and using one's time on earth wisely. While the latter theme, depicted in the middle third, is fairly innocuous in latent meaning, the bottom third has certain typological and ecclesiastical overtones that approach decorous ceremony. Where the "Davidic altar frame" surrounds a work's title with pillars, this woodcut has a skull and hourglass on top of the words "Redeemth Tyme Eph 5" and a maiden on top of 
"Watche Mat. 25." As Brown notes, the skull (death) is the only face directed towards the reader, while all others are oriented towards God's name; the maiden - like those depicted in the frontispiece to Ancilla Pietatis - holds a torch and waits patiently. Underneath the title is a paraphrase of 1 Timothy 4:8, "Pietie hath the promise." 41 The bottom third of the frontispiece depicts Exodus 17, wherein the Israelites overcome the Amalekites, shown here as a fight between the spirit and the flesh. While the word Baptisme floats in the Red Sea, there is no further sacramental importance in the image. The most interesting part of this depiction of Exodus 17:12 of the three men kneeling on the hill in prayer: a mitered Aron, Moses with his hands being held up, and Hur. Underneath each man is a word, respectively Faith, Prayer, and Fasting. Where the account in Exodus has Moses sitting on a stone, here a monolith with the word Christ inscribed sits in front of the three men, perhaps a typological allusion for the altar that the men build, which in Exodus is called Jehovah-Nissi ("the Lord is my Banner"). Ryrie, who elsewhere calls Bayly an unmistakable puritan, discusses this image in the context of the ceremonial holdover from the mass in holding hands up to pray; together with Wilcox's note that Aaron's role as the first high priest of the Old Testament made him a "type or forerunner of Christ and all priests of the new covenant," the image endorses a ceremonial use of prayer along with the private prayer of the "Pious man," whose arms are crossed across his chest. ${ }^{42}$ Rather than pin one version or method of prayer against the other, Bayly's frontispiece shows both to be pleasing, provided the acts of piety are performed in good faith. Altogether, the frontispiece picks up on the first word of the title, Practise, which emphasizes that the pious Christian must be active in their devotion. 
In the text of the devotional, Bayly describes piety in almost all of its forms, including sacramental participation. One of the major through-lines of Bayly's brand of piety is avoiding presumption. ${ }^{43}$ Congruent with other meditations on communion, the Eucharist, for Bayly, is the occasion for the Christian sinners to know their place, meditate on their unworthiness, recognize the salvific benefits of participation, and, after partaking, give thanks. Even though Bayly wrote before the altar/table debate, Bayly's text shows the precariousness of using an individual's nomenclature to identify their religious "camp." 44 Two examples from Bayly will show that, though he uses table almost exclusively in reference to communion, behavior at the table reveals sympathy to, but not exact alignment with, the proto-Laudian view that sitting at communion presumes that humans are coequals with Christ or God. Partaking in the Eucharist provides assurance of Christian salvation, but that assurance happens after consuming the elements. In explaining that assurance, Bayly writes: "The Lords Supper is both a meane and a pledge unto us of this spirituall and first Resurrection. Hee that eateth mee, even hee shall live by mee. And then are we fit Guests to sit at the Table with Christ, when like Lazarus wee are raysed from the death of sinne to newnesse of life" (707). ${ }^{45}$ In the postcommunion prayer, Bayly meditates on the propriety of approaching Christ: "And who is fit to entertaine Christ? or who though invited would not choose, with Mary, rather to kneele at thy feete, then presume to sit with thee at the Table?" (770). In both of these examples, Christians in their natural, unregenerate state are not fit to sit with Christ, as they lack reverence and grace - not until eating are they then fit Guests. ${ }^{46}$ Kneeling reflects a level of humility and subservience more appropriate, but through election and reflecting on what the Eucharist does, Christians can rightfully sit and partake - but only 
at Christ's invitation. Most proto-Laudians tend to ignore this invitation in an effort to emphasize the majesty of God and encourage more general sacramental participation.

In addition to avoiding presumption, humility and subservience are at the heart of Bayly's brand of devotion. Though much of Bayly's concern is with the regeneration of grace, he also draws attention to the worldly, unregenerate man who epitomizes hypocrisy in believers. Much like other authors in this project, Bayly urges external actions to match the inward mind, arguing that lacking either the internal or the external element is profane. In outlining errors in the practice of religion and arguing against the misinterpretation of taking justification by faith to mean that good works are not necessary, Bayly includes one lengthy exhortation on the blending inner and outward forms of devotion. This one passage contains several motifs already seen in this project, though Bayly predates them - including the wrongful separation of inward and outward, hypocrisy, profaning the Sabbath, humility in worship, and worship and service. Bayly writes on the unregenerate man, who represents superstition, vanity, and profaneness:

When the unregenerated man heares that GOD delighteth more in the inward minde then in the outward man. Then he faineth with himselfe, that all outward reverence and profession is but eyther superstitious or superfluous. Hence it is that hee seldome kneeleth in the Church: that hee puts on his hat at singing of Psalmes, and the publike Prayers, which the profane varlet would not offer to doe, in the presence of a Prince or a Noble-man. And so that hee keepe his minde unto GOD, hee thinkes hee may fashion himselfe, in other things, to the World. Hee divides his thoughts, and gives so much to GOD, and so much to his owne lusts: yea, hee will devide with GOD the Sabboth and will give him almost the one halfe, and spend the other wholy in his owne pleasures. But know, o carnall man, that Almightie GOD will not be served by halfes, because hee hath created and redeemed the whole man. And as GOD detests the service of the outward man, without the inward heart, as Hypocrisie: so hee counts the inward service without all externall reverence, to be meere profanenesse; hee requireth both in his worship. In prayer there-fore bowe thy knees, in witnesse of thy humiliation: lift up thine eyes and thy hands in testimonie of thy confidence: hang down thy head, \& smite thy breasts in token of thy contrition, but especially call upon God with a sincere heart: serve him holy, serve him wholy, serve him onely, for GOD 
and the Prince of this world, are two contrary Masters, and therefore no man can possibly serve both. (246-48)

Aside from the initial italicized phrase, all italics reflect Bayly's own emphasis and serve as Laudian keywords, emphasizing the whole man who combines the inward heart with outward acts in sincere worship. This passage stems from Ambrose, with Bayly paraphrasing Deus magus delectatur affectu quam effectu [God prefers passion to performance] to differentiate between inner and outer. The sentiment is not wholly biblical, though Psalms 51:6 and Romans 7:22 seem relevant (respectively, from the KJV: "Behold, You desire truth in the inward parts, And in the hidden part you will make to know wisdom" and "For I delight in the law of God after the inward man"). ${ }^{47}$ The inward-outward dichotomy is joined together in the whole man (expressed in an Andrewesian pun on holy/wholy/onely), which stems from Bayly's marginal reference to Matthew 6, where Jesus admonishes against hypocrisy and serving two masters in the Sermon on the Mount. When considering Laudian viewpoints, Bayly’s “unregenerate man" resembles the homely puritans of Andrewes and Buckeridge that dismiss gesture as superstitious (though, for the latter two, the debate usually concerns communion). All three of their conclusions are the same: it is just as hypocritical to (pretend to) practice inward devotion without any external showing as it is to act pharasiacally and gesticulate without any inward meaning. The profaneness of the hypocrite shows the worldly receiving attention that the heavenly should receive. The emphasis on gesture appears later in Bayly's instructions to the household: "After the Psalme, all kneeling downe in reverend manner, as is before described, let the Father of the Familie (or the chiefest in his absence,) pray thus" (468). This later example is a call to prayer, but the lengthy passage above is about religion in general, not tied specifically to prayer alone and is 
silent on the means of taking communion. Nonetheless, the dichotomy of inward/outward pairs nicely with devoting all of the Sabbath to the Lord, and for Bayly, the pious man worships completely.

One thing that distinguishes Bayly's exhortations for proper worship observation from Tymme or Andrewes acting as "custodians of order" is that, when Bayly spells out the obligations of service and duty, he moves beyond simply admonishing worshipers to participate and elaborates on how these acts of service edify. Genre, naturally, plays a role: sermons orally call to action; devotionals are guidebooks that can break down those actions in greater detail. Bayly's Sabbatarianism, seen in his explication of the fourth commandment, guides behavior for all parts of the Sabbath day, not just that time spent at a church. Regarding holy assembly, Bayly argues for orderly conformity and, like Andrewes and Cranmer, does so citing 1 Corinthians. While Bayly appears to resemble Tymme in arguing that public prayer public prayer is the joining together of minister with congregation, Bayly maintains that corporate worship, with its mandated participatory activities, sets aside individual or private concerns for the entire community of saints. In the following passage, he takes a soft stance toward gesture, seeking like Herbert to avoid controversy and obstinacy:

When praiers begin, lay aside thine own private Meditations; and let thine heart joine with the Minister, and the whole Church, as being one body of Christ; and because that GOD is the God of order, he will have all things to bee done in the Church, with one heart and accord: and the exercises of the Church are common and publike. It is therefore an ignorant pride, for a man to thinke his owne private prayers more effectuall, then the publike prayers of the whole Church. Salomon therefore adviseth a man not to bee rash, to utter a thing in the Church before GOD. Pray therefore when the Church prayeth, sing when they sing, and in the action of kneeling, standing, sitting, and such indifferent ceremonies (for the avoyding of scandall, the continuance of charity and in testimony of thine obedience) conforme thy selfe to the manner of the Church wherein thou livest. (594-95) 
Though Bayly sidesteps any polemical debate about extemporaneous or set prayers, he does cite the ignorance of the individual who presumes that private prayer is any more (or less) effectual than conforming to public prayer. Honoring the Sabbath requires participation through gesture, act, and attention, but, reaffirming the conventional view ceremony-as-adiaphora, Bayly stresses that gesture is a less important part of conformity. Because gestures are indifferent, individuals should follow the church's prescription. He leaves enough wiggle room that individuals can seek out a different church (silently) to find a more agreeable practice - this suggests he would be enough of a puritan to find Cosin's in-service rabble-rousing distasteful. Side-by-side to the italicized call to kneel, stand, or sit, are two marginal biblical citations, Ezekiel 46:10 (where the prince goes forth with the masses to worship) and Psalm 110:3, which has noticeable differences in the Geneva and King James Version (published a year or two prior to the first edition of Practise of Piety). In the Geneva, Psalm 110 has an epigraph of David prophesying about the power and kingdom given to Christ's priesthood as it replaces the Levite priesthood. Verse Three reads: "The people shall come willingly at the time of assembling thine army in holy beauty: the youth of thy womb shall be as the morning dew." Alternatively, the annotation-free KJV reads: "The people shall be willing in the day of thy power, in the beauties of holiness from the womb of the morning: thou hast the dew of thy youth." Ironically, the KJV is less clear that this verse concerns the Sabbath. While the phrase beauty of holiness seems incidental, it nevertheless suggests Sunday worship attracts a type of beauty in recognizing God's power. For Bayly, the concern is less with beauty than with order and avoiding scandal. The parenthetical assertion to exercise charity in place of seeking scandal stems from patristic evidence. To paraphrase the translation, the 
margin says "When I come to Rome and the Jewish Sabbath, I come as I am, not as a Jew. Thus you should come following the customs of the church to avoid scandal" (595). ${ }^{48}$ When in Rome, Bayly asserts, do as the local churchgoers do. Unlike Featley or the Avant-Garde Conformists, Bayly is content to leave this reference ambiguous, where it could (and most likely does) refer to the local church or the wider established custom of the diocese or state church.

Another factor to distinguish Bayly from the more clear-cut "custodians of order" is Bayly's instruction on proper behavior during the sermon. Despite Fincham's and Doerksen's dichotomy, the "custodians of order" are not against sermons, but their apparent centrality in worship. Like Buckeridge's admonition that sermons are but a "part" of worship, Bayly, too, argues that sermons are but a part of worship and require further action on the part of the hearer. ${ }^{49}$ Compared to the others (including Tymme), Bayly is more assertive in instructing his reader on how to behave, which accounts for whether the reader is a minister himself or a layperson. Bayly does not divorce public prayer and sermons; he exhorts his reader to stay after the sermon. Immediately following the above passage, Bayly directs in-church behavior, focusing on how to listen to a sermon:

Whilest the Preacher is expounding and applying the word of the Lord: looke upon him; for it is a great helpe to stirre up thine attention, and to keepe thee from wandring thoughts, so the eyes of all that were in the Synagogues, are said to be fastned on Christ whilest he preached: and that all the people hanged upon him when they heard him. Remember that thou art there as one of Christs Disciples, to learne the knowledge of salvation, by the remission of sinnes, through the tender mercy [of] God. Luk. [1]:77. (595-96)

Bayly's instructions here remind me of Cosin's passive acceptance of non-idolatrous imagery: Christians look, observe, and do in order to stir up their attention and promote 
piety. ${ }^{50}$ Even, or especially, in listening to sermons, there needs be an active doing of things. This nicely pairs Bayly with Andrewes's prescriptions against idle sermon hearing and becomes more explicit when he compares some sermon-goers to idle schoolboys, "that often heareth, but never learneth [their] lesson" (596). Lest this be construed as partisan, Bayly then offers a four-part division of how to make sermon-hearing profitable - one that strongly resembles Perkins's sermon prescriptions: listeners should focus on the coherence and explication of text; the sum of the holy spirit in the text; the division of the text; and the doctrines and proofs thereof. ${ }^{51}$ When faced with "too curious or confused" preachers who cannot parse together a cogent sermon, Bayly proposes listeners focus on how many things they learned, what sins to reprove, and what virtues were nonetheless exhorted by the preacher, remembering that the preacher is speaking as if by God, rather than man (596-99).$^{52}$ Implicit in Bayly's advice is the importance of acting upon the exhortations, rather than idly - or profanely - assuming that sitting in attendance is a pious act in itself.

These active duties are reiterated in Bayly's description of what to do following the conclusion of the sermon. Eschewing the false dichotomy between sermon- and sacramental-piety, Bayly connects the sermon to the sacrament, even using the Calvinist "tinted" vocabulary of table and minister. He writes, in for "When the Sermon is ended,"

Beware thou depart not like the nine Leapers, till that for thine instruction, to saving health; thou hast returned thankes and praise to GOD by an after prayer, and singing of a Psalme: and when the blessing is pronounced stand up to receive thy part therein, and heare it; as if Christ himselfe (whose Minister hee is) did pronounce the same unto thee, for in this case it is true, Hee that heareth you, heareth mee: and the Sabbath day is blessed, because GOD hath appointed it to be the day, wherin by the mouth of his Ministers, hee will blesse his people, which heare his word, and glorifie his Name. For though the Sabbath day in it selfe be no more blessed then the other sixe dayes; yet (because the Lord hath appointed it to holy uses above others) it doth as farre excell the other dayes of the weeke, as 
the consecrated bread (which wee receive at the Lord ['s] Table) doth the common Bread which wee eate at our owne Table. (600-601)

Though he alludes to the Lepers rather than Chrysostom's anecdote about leaving after the sermon, this message is consistent with Andrewes's call to partake in the whole service, rather than just the sermon. The call to sing the Psalm and stand up echo his earlier remarks to honor the Sabbath through participation, in both the service itself and communion. Bayly's exhortations to participate in corporate worship fall along lines that often are applied to the Avant-Garde Conformists, but the popularity of the Sternhold and Hopkins Psalter show that even if Calvinists did not always conform to the $B C P$, they did include worship and singing in their services. ${ }^{53}$

Lastly, Bayly's views on worship relevant to proto-Laudianism stem from avoiding presumption. To take one brief quotation from one of his seven "hindrances to piety," Bayly sums his views on active worship. He writes of "The evill example of great persons," saying that "The practise of [sic] of whose prophane lives they preferre for their imitation, before the precepts of Gods holy word. So that when they see the greatest $m e[\mathrm{n}]$ in the state, \& many chiefe Gentlemen in their Countrey to make neither care nor conscience to heare Sermons, to receive the Communion, nor to sanctifie the Lords Sabbaths, \&c... they thinke that Religion is not a matter of necessity" (254-55). This view sums up the public-facing aspects of Christian worship: hear sermons, receive communion, and sanctify the Sabbath while respecting the moral and ceremonial law in public practice. To ignore these is to "rowe against the streame of impiety towards heaven" (256). These acts are not inherently confessional, and thus have a wide appeal. While Bayly's strict Sabbatarianism aligns him with some more ardent puritans, his ceremonial conformity strikes several Laudian chords and his elevation of common 
prayer over public go against the grain of several stereotypical puritan positions. In turning to the last two publications in this chapter, we find two authors whose biographies and writings diminish the value of strict confessional labels.

\section{Exeter: Henry Tozer's 1628 Directions for a Godly Life and Charles Herle's 1631 Contemplations and Devotions}

While a communion manual and a book of meditations on the Passion might not appear to have much in common at a surface level (aside from, perhaps, the Eucharist being made possible through the Passion, which we will see in Herbert's opening sacrificial sequence in The Temple in the next chapter), I nevertheless join together the two works in this section because their authors share a similar set of circumstances. Both men matriculated at Exeter College, Oxford, dedicated their books to their Exeter-bound tutees, and, in the 1640s, were nominated to the Westminster Assembly. ${ }^{54}$ Traditionally, neither fits the billing of a Laudian, though their views on ordered worship or prayerbook conformity suggest Laudian sympathies. Henry Tozer, whose Directions for a Godly Life went through eleven editions between 1628 and 1660, is commonly classified as a "precise puritan," though his refusal to attend the Westminster Assembly may have predicted his later "acceptance from the Laudian establishment" when he was expelled from Oxford for reinstating the $B C P$ in 1648 over the Directory of Public Worship. ${ }^{55} \mathrm{He}$ is also remarkably understudied. Conversely, Charles Herle attracts more attention for his political writings of the 1640s, written in support of parliament and limiting the absolutism of the monarch. He left London after Charles's execution. ${ }^{56}$ Less cited is his Contemplations and Devotions ... on our blessed Saviors death and Passion, a collection 
of 27 scriptural meditations that only went through one edition in $1631 .^{57}$ Although neither of these books ostensibly promote Laudian themes, their approaches to hypocrisy, reverence, gesture, and the sacrament show variations of themes established in this project that are neither antithetical nor dismissive to those views. Both reveal a sense of conforming to moderation and tradition.

Tozer's manual on communion avoids controversial positions, though its use of set forms of prayer - not a dramatic site of contention in the $1620 \mathrm{~s}$ - perhaps predicts Tozer's sympathy for the $B C P$, which belies his "precise puritan" label. ${ }^{58}$ The most conventional aspect of this manual is his definition of a sacrament, which is a conduit of grace, the visible recognition of God's covenant to mankind: “A Sacrament is an outward visible signe of an inward and invisible grace; ordayned by God, whereby hee doth seale unto us his covenant of grace made in the blood of Christ, and wee againe testifie our faith and piety towards him: so that it is both a signe in respect of the thing signified, \& a seale in respect of the covenant thereby sealed unto us" (Directions 13-14). ${ }^{59}$ Because of its salvific importance, Eucharistic participation requires the proper state of mind, body, and soul on behalf of the believer. Much of Tozer's attitudes echo Bayly's against presumption. However, Tozer perhaps best exemplifies the adiaphoric attitude of gesture when it comes to the sacrament. Tozer's Directions emphasize the preparatory meditations to prepare the soul to receive Christ's sacrifice. We see this in the sole reference to kneeling, which occurs only in private settings: "Let us take some time unto our selves, wherein wee may bee most private; and shut our selves up in our closets, and there humbly on our knees lay open before God those sinnes, which wee have committed in our life past" (96). ${ }^{60}$ Kneeling is subsidiary to the inner reflection that precedes 
penitence and confession. Moreover, at communion itself, Tozer urges that "we are to sit, and feede in the presence of the Lord himself" (56). Unlike the Laudians, Tozer argues for sitting the "Princely table." Like the Laudians, however, Tozer urges approaching the table as one would approach an earthly king. Individuals should present themselves as reverent, "disposing all things in the most decent order" (56). Indeed, the argument that we must not "deceive the Lord with an hypocriticall out-side; for hee looketh not the outward gesture onely, but to the inward parts of the soule" sounds like something out of Buckeridge's sermon and discourse on kneeling (57). Instead of arguing for the propriety of the gesture, Tozer instead emphasizes the inner state of being. The lack of proper selfhumiliation marks one as a hypocrite, who, instead of receiving grace, commits an offense of "special disgrace and indignity" and invites punishment instead of reward (59). ${ }^{61}$ Both Tozer and Buckeridge would agree that inner piety must be present for gesture to be reverent. Buckeridge argues that those who do not kneel at all are hypocritical, while Tozer would argue that it is easier to be hypocritical in absentmindedly kneeling at what should be a most reverent occasion.

The argumentation about hypocrisy and proper preparation shows that Tozer's churchmanship, in this case how to behave in relationship the sacrament, has much in common with the Laudians, even if he diminishes the role of gesture. Unsurprisingly, Tozer refers to 1 Corinthians 11 to support his decent and orderly worship prescriptions. Of the seven references, two will suffice here. First comes from as section on the need for self-reflection and examination before the sacrament: Tozer says it is Paul who "biddeth us to examine: \& then eat" (49). ${ }^{62}$ This leads to the second example, of recognizing the holiness and dignity of the occasion: "Saint Paul saith. 1. Cor. 11.27. that is, wee offer 
speciall disgrace and indignity unto Christ, in not receiving him with that revere[n]ce which we ought: which offence, as it is in it selfe very hainous so it drawes on us a fearefull punishment" (59). Communion is a time for reverence, so Christians should also display reverence for the occasion and for their faith. While Tozer prefaces this with the importance of inner reflection, Eucharistic participation is a public testament that can be used to stir up the devotion of others: partaking "is, a testifying of our faith unto others; for hereby wee both shew unto others the faith, which wee professe; and also by our example stirre them up to the performance of the same duty; in this respect therefore it is necessary that wee should often receive" (38). For Tozer, then, the sacramental element to communion requires personal, inner meditation and an outward testament, which is presented without an overt emphasis on the gesture. ${ }^{63}$ The outward show comes from proper preparation and stirs up others through the display of piety, presumably through witnessing someone who has reverently prepared themselves for the receiving of grace.

Stepping away from Eucharistic preparation, or perhaps extending the personal preparation to public exercise of the sacrament, Tozer also speaks to the importance of prayer, aligning himself closely with views laid out by Tymme in advocating for both private and public prayer together. This practice includes the importance of acknowledging divine patterns for prayer. For Tozer, prayer is like communion, in that it joins individual preparation with communal practice. In the tenth chapter - "Of Premeditation and Prayer" - Tozer lays out a plan for Christians to prepare themselves for the sacrament, arguing that prayer is a source of comfort that should be done first in private, and secondly "in publike with the Congregation; where we ought to present our selves at the very beginning, that so wee may joyne together in all things where we are to 
performe" (144-5). Tozer includes some short formal prayers. He argues that there are two considerations in praying, for whom a Christian prays and how (in humility). It is in the former that we see the importance of set prayers: "for whom we ought to pray [ourselves and others] ... which wee learne from the patterne of prayer, the Lord's Prayer, left unto us by Christ himselfe" (146). Ryrie suggests Tozer's attitudes towards the Lord's Prayer, as well as the creeds and commandments, makes it so that the simple could recite them without understanding them. ${ }^{64}$ This is the line of thinking that leads The Directory of Public Worship to ban set forms in favor of extemporaneous prayers as an attempt for more sincerity in pastor-led prayer. ${ }^{65}$ As Tozer would later face censure expulsion as Oxford fellow - for disallowing the Directory and Parliamentary ban of the $B C P$ - it is important to note that here, almost two decades earlier, Tozer stresses the importance of learning from patterned prayer. The potential for vain repetitions exists, but, in line with proper meditation and reflection, properly trained or mindful Christians repeat the forms for their own edification. This is a methodology mirrored by more explicitly Laudian prayer manuals. ${ }^{66}$ By being mindful of what the forms mean, a Christian avoids hypocrisy and presumption.

Humility seems to the key to Christian performance that evades hypocrisy or acting like the outward facing publican and Pharisee. This stress for sincerity within the Directions begins in the dedicatory epistle, which both stresses the personal nature of these meditations and provides a tangible link to Herle's book of contemplations. The epistle suggests that it Lorzeno Cary, the son of Vicount Faulkland the Lord Deputy of Ireland, was the individual for whom the "private use" of this work was originally intended (3). An otherwise typical appeal for patronage, this epistle reveals that Tozer 
tutored Cary in the latter's youth. At the time of publication, Cary was a student at Exeter, a fact that makes Tozer highlight the "religious government of this Colledge" (4). However, Tozer continues showing that he intends his manual to lead the active performance of one's duties. The "Due consideration of those holy duties" is a subject matter not "of humane learning, but of God's service," which is greatest in communion and deserves a public audience so that the sacrament can be "sincerely practis'd" (5-6). While it might be tempting to pit Tozer's sacramental emphasis against sermon hearing, Tozer admonishes that the "spirituall exercises" of "hearing Gods word and receiving the Sacraments" together strengthn one's faith and understanding of piety and religion (523); he echoes this sentiment later, stressing that repentance comes from faith, a "gift of God, begotten and increased by hearing the word, and receiving the Sacrament" (75). In both cases, the work's only references to, hearing coexists with the sacrament. ${ }^{67}$

Charles Herle's Contemplations and Devotions opens with the same rhetorical gesture as Tozer's Directions. Herle, himself an MA and "sometimes of Excester Colledge in Oxford" dedicates his devotional to James, Lord Strange and his father, William, earl of Derby ${ }^{68}$ Herle's epistle is more formulaic and laudatory than Tozer's, though he reveals that these devotionals were composed while recovering from a sickness while in the household of Lord Strange. He humbly professes that he made "my unlabour'd pastime of thinking, thus venturously publique" not for friends, or "any overweening opinion of the word" but for "Gods glory, and your Lordships service" (Contemplations, sig. A5r-v). In line with Cosin's and Featley's deovtions, Herle also demonstrates a confessional or political purpose in publishing these devotions. He argues that he made it "in the first place [for] the vindication (as much as in me lyes) of our 
Religion from that common brand which her Romish adversaries so frequently upbrayd her with, that she spends all her devotion on the Pulpit, and keepes none for the Closet" (sig. A5v). A variation on the English private devotional debate, Herle's offering provides an alternative to a sermon-centered piety that concerned Tymme, Buckeridge, Andrewes, and others. Herle's objective is to create an explicitly Protestant devotional. As might be expected from meditations on the passion, Herle's relevance to this project appears through his admonishing against presumption and for the proper uses of kneeling.

Indeed, like Tozer, Herle has a concern with the hypocrisy latent in empty actions. In the meditation on Jesus commending his mother to John, Herle says both Saul and Judas were flawed because they exhibited "outward graces without inward grace," the examples of whom "close without truth, serve but to inhanse and dis-excuse a mans damnation" (415). This concern for having external shows of piety reflect the inward state is consistent throughout the meditations. One example comes from an apostrophe within the prayer-like meditation: "But (alas Lord) have I not as often too with these thy Murderers mock'd, blindfolded, buffeted, spat on thee? What else doth hypocrisie but mocke thee, and so, how often have I even in my prayers bowed the knee before thee, and not the heart; given thee the empty title of a King, and not the tribute?" (134). ${ }^{69}$ The concern for hypocrisy draws in and speaks to concerns of gesture. Herle's fear of his soul having "spat the noisome slaver of blasphemy and prophanesse" speaks again the irreverence of not having considered his state before God's majesty. Like Tozer, Herle focuses on reverence in general, and not just when kneeling. However, this difference shows the general principles underlying reverence and humility: they should appear in all 
forms of worship, not just the ceremonial or sacramental. Apropos to the fear of profaneness, Herle has been interpreted, like later Laudians, as treating God like an earthly king - a not surprising condemnation given how often the comparison between God's majesty and the majesty of James or Charles has been invoked in the sermons and devotionals in this project. ${ }^{70} \mathrm{~A}$ similar relationship between humility and gesture appears in the meditation on Barabbas's release, focusing on Christ's willfulness in acting humbly: "whereas the Camell willingly kneeles downe to take on his burden, as fit an embleme of our Saviour, who willingly humbled himselfe, and stoop'd to the burden of our sinnes" (229). For gestures to be emblematic of faith, they need to be representative of one's inner state, which before God should be one of humility and meekness.

Without balancing inner humility with outward shows, one gives way to hypocrisy. Unlike Tozer, Herle speaks to different gestures. Herle coyly tries to avoid equating "bowing" with "kneeling," which he does with careful and selective allusions to the second chapter of Philippians. The above example ("who willingly humbled himselfe") alludes to Philippians 2:8 (KJV: "And being found in fashion as a man, he humbled himself, and became obedient unto death, even the death of the cross."). This verse, with its surrounding context, features prominently in the meditation on "He bowes downe the head and gives up the ghost." The essence of Philippians 2 equates Christ's humility and his lowness with the physical act of bowing, which should be done by everyone: "But this bowing downe hath a double lesson, obedience, and humility; how high a degree of obedience? hee became obedient to the death, even the death of the Crosse; how lowe a degree of humility?" (449). A few pages later, a longer passage on bowing the head repeats this same marginal reference: 
wilt thou ever take in a proud man thither? let me be sure then with thee to bowe downe my head; my heart, before that I give up my ghost: 'twas ever thy method (Lord) to stoope, that thou might'st rise, thou humbledst thy selfe (sayes thy Apostle) and so thou wert exalted: nor is this gesture but very suitable to the worke in hand; now art thou about to give up the ghost as a sacrifice for my sinnes, the head therefore shall supply the office of the restrayned knee, and bowe in reverence to so great a sacrifice, and didst thou bowe the head (Lord) in giving thee, and doe any thinke it much to bowe the knee in receiving thee? but how well (in many respects) might'st thou say, that thou powredst out thy soule to death? whither wee respect the freenesse, or abundance of the gift, thy bloud, 'twas neither a strayning, nor a sprinkling, but a free and full powring of it; and didst thou thus give up thy ghost, thus powre out thy blood, thus freely, thus fully for me? and can I be so eye so hart-bound, as not to powre out some teares to thee? (451-2)

What is notable in these passages is that Herle restricts the bowing of Philippians 2 to the bowing the head, which ignores the explicit reference of Phil. 2:10 calling for the bowing of the knee: "That at the name of Jesus every knee should bow, of things in heaven, and things in earth, and things under the earth; And that every tongue should confess that Jesus Christ is Lord, to the glory of God the Father." Even though humility leads to certain gestures, Herle, whether in an attempt to avoid controversy or to diminish the act of kneeling altogether (unlikely, as the quotation in the last paragraph urges sincere kneeling in prayer), avoids the culmination of this scriptural allusion. Nevertheless, Herle emphasizes the joining of inner humility with external acts and uses the sacrificial nature of the passion to make that point.

\section{Conclusion}

The argumentative crux of these devotional works - just a small sampling of the hundreds published in the seventeenth century - is that even mainline Calvinists and puritans have religious views sympathetic to Laudianism. The "muddled" nature of Protestant thought in this period shows that prayerbook, sacramental, or ecclesiastical conformity took many forms and did not rely upon rigid theological structures like 
predestination or real presence (nor did these particular works place an undue emphasis on these issues). Conformity ultimately boils down to avoiding presumption in an attempt to live humbly. Regardless of whether one kneels, prays, or observes the Sabbath, Christians received instructions to be deeply mindful of their behavior, with ostentation occurring in the sense that their actions can be used to stir up the faith of others. For this to occur, gesture must reflect the inner piety of a meditative Christian, cognizant of their own sinfulness and the grace offered them through the Sacraments and hearing Scripture.

Another element made prominent in this chapter is that several Laudian themes transcend genre. The exhortations made by Andrewes and Buckeridge in their sermons also appear in the didactic and sometimes argumentative prose of private devotions. In the next, and final, chapter we turn to George Herbert's The Temple, published in 1633 the same year as Laud's ascension to Archbishop of Canterbury. Like the devotionals written for private use, lyric poetry often has claims of private origin. Like the subtitles or dedicatory epistles of the devotionals seen here, Herbert's dedicatory poems make clear the public-facing didactic use of his verse. Thus, his poems have confessional potential. However, rather than claim Herbert is not a Calvinist, I argue that his brand of Protestantism makes use of a Laudianism that is not anti-Calvinist and celebrates the liturgy and ceremonial elements for their uses as tools for private and inner devotion.

\footnotetext{
${ }^{1}$ Some met with success in later years. After the initial publication of Practise of Piety (c. 161112), Lewis Bayly proceeded DD (1613) and became Bishop of Bangor (1615), which was a poor diocese. In this sense he is like Cosin, who published A Collection of Private Devotions before having proceeded DD (1630) and becoming Bishop of Durham in 1660. For comparison, Featley already had his DD by the time he published Ancilla Pietatis.

${ }^{2}$ Green, Christian ABC, 294; McQuade, Women Catechists, 141-161. Burch, however, was sympathetic to anti-Laudian concerns.

${ }^{3}$ This is not to say that these topics are exclusive to Laudians but that they often appear in Laudian works.
} 
${ }^{4}$ Ryrie, Being Protestant, 222-4, makes the case that set prayers (even without explanations) had their own didactic purpose in teaching individuals how to pray or in providing models. Garrett, 349 , argues that the debate over set prayers was more about their use in public prayer, rather than private.

${ }^{5}$ For full bibliographic information, including number of editions, see Green's appendix in Print and Protestantism. The works referenced include: Isaacson/Andrewes's Institutiones Piae (1630), Andrewses Preces Privitae (1647), Laud's Officium Quotidianum (1650), Richard Allestree Whole Duty of Man (1658), John Norden's Pensive Man's Practice (1584), Arthur Dent's Plain Man's Pathway to Heaven (1601), and Michael Sparke's Crums of Comfort (1623). The last four were all best sellers; Sparke, a noted puritan, provided mostly set prayers. He does provide evidence, however, for Ryrie's claim that kneeling at prayer itself was not controversial. He writes, Crumms of Comfort (London: 1627 [6 $6^{\text {th }}$ ed.]), sig. A5r: "The most decent \& fitting gesture is kneeling, and looking up to Heaven." However, his list of "decent gestures" excludes kneeling while including going, standing, lying, or sitting.

${ }^{6}$ While I emphasize the similarity to other 1618 publications, Fincham, 232-3, also identifies the influence of John Howson (complementing Andrewes and Buckeridge) in the sermon, prayer, and ceremony debate, having commented on these manners in sermons printed in 1598 and 1602. As regards 1618, McCullough, in the digital appendix to Sermons at Court, 216-25, esp. 225, notes that, in 1618, attacks against sermon-centered piety and extemporaneous preaching were a mainstay at Whitehall, as preached by Andrewes, Buckeridge, and Donne. Comparatively, Bruce Janacek, "Thomas Tymme and Natural Philosophy: Prophecy, Alchemical Theology, and the Book of Nature," The Sixteenth Century Journal 30.4 (1999), 991 and 1006, notes a "clear bent toward prophecy" in Tymme's early works (but not in Chariot of Devotion). In his 1618 Whitsunday Sermon, XCVI 720, Andrewes preaches on prophesying in relation to sermons. ${ }^{7}$ Green, Print and Protestantism, 308-11, 369. Cf. Janacek, 989: "Tymme was a clergyman in the Church of England, whose writings indicate that he probably adhered to Calvinist doctrine; he nevertheless believed in the efficacy of alchemy. Tymme accepted the Calvinist belief that the Word of God was contained in sola scriptura and that one's salvation was dependent upon predestined and immutable divine election."

${ }^{8}$ T.P. J. Edlin, "Tymme, Thomas (d. 1620), translator and devotional writer," Oxford Dictionary of National Biography. (23 Sep. 2004; accessed Dec. 8, 2020). Ryrie, Being Protestant, 353, citing Chariot, A3r-v; "Thomas Tymme," Wikipedia. https://en.wikipedia.org/wiki/Thomas_Tymme, (accessed 8 Dec. 8, 2020), which cites Richard Greaves, Society and Religion in Elizabethan England (Minneapolis: University of Minnesota Press, 1981), 234.

${ }^{9}$ Thomas Tymme, Preparation against the Prognosticated Dangers of this Year, (London: 1588), sig. B6r. His first publication available on EEBO is The Figure of Antichrist (London: 1586), which reads 2 Thessalonians as apocalyptic admonition against popery, referring to patristic and continental authorities alike, including Calvin. The last chapter in his A Silver Watch-bell (London: 1605) last chapter on "alterations to true religion in all ages" takes aims at antichrist popery and Muslims.

${ }^{10}$ Preparation, sig. B4v, and The Poor Mans Pater Noster, (London: 1598, second impression), sig. A1v. The latter text contains prayer-expositions on the Lord's Prayer and a number of other prayers, psalms, and meditations.

${ }^{11}$ McCullough, "Buckeridge, John," para 5. See Chapter One above.

${ }^{12}$ Green, Print, 311.

${ }^{13}$ Jennifer Richards and Fred Schurink, "Introduction: The Textuality and Materiality of Reading in Early Modern England," Huntington Library Quarterly 73.3 (2010): 360. For set prayers as didactic, see Ryrie, Being Protestant, 222-4.

${ }^{14}$ Fincham, 248-93. See also Doerksen, "Custodian of Order," in which he argues Donne embodies the Preaching Pastor mode against Andrewes's custodian. 
15 “The Church-porch," lines 397-8 and 409-10.

${ }^{16}$ Tymme argues for prayer in all places - closet, church, and everywhere else. Chariot, 47.

${ }^{17}$ Contrastingly, Prynne, Brief Survay, 82, cites Brownists together with Papists as parties that would celebrate Cosin's crypto-Catholic traditions.

${ }^{18}$ See Garrett, 345-52.

${ }^{19}$ Cf. Andrewes, XCVI Sermons, 1129-1142 (as 129-142).

${ }^{20}$ Being Protestant, 180.

${ }^{21}$ Ryrie, Being Protestant, 203-4.

${ }^{22}$ See also Herbert's commentary, in "The Church-porch," lines 406-8: "make thy self all reverence and fear. / Kneeling ne're spoil'd silk stocking: quit thy state. / All equall are within the churches gate."

${ }^{23}$ Kate Narveson, "Flesh, Excrement, Humors, Nothing: The Body in Early Stuart Devotional Discourse," Studies in Philology 96.3 (1999): 317-18.

${ }^{24}$ See also Hooker, Lawes, V.IV.3.27, who cites Romans 12:1 as support of arguing "There is an inward reasonable, and there is a solemn outward serviceable worship belonging unto God. Of the former are all manner virtuous duties that each man in reason an conscience to Godward oweth. Solemn and serviceable worship . . . belongeth to the Church or public society of God by way of external adoration."

25 "All the days of our lives" is a commonplace liturgical phrase, but is the end of Andrewes's sermon-text for his 1617 Gunpowder Sermon, in which he orates on the covenant between God and Christian. Tymme's prose is in line with Andrewes, as he continues to say that the servants are "tyed and indebeted [to God] for infinite benefits."

26 "The Church-porch," 408-9.

${ }^{27}$ Cf. Herbert's "The Windows," 13-15: "but speech alone / Doth vanish like a flaring thing, / And in the ear, not conscience, ring."

${ }^{28}$ Compare Buckeridge's "Hearing is but a part" in Chapter One.

${ }^{29}$ Cf. Andrewes, Sermon . . . November Last, 36.

${ }^{30}$ Ryrie, Being Protestant, 325

${ }^{31}$ Another appropriate label, ignoring the false dichotomy between sacrament- and word-centered worship, would be Robert Whalen's "sacramental puritanism," originally applied to Herbert.

${ }^{32}$ Lewis Bayly, The Practise of Pietie, (London: 1613). The ODNB states an unknown first edition with the second edition appearing in 1612.

${ }^{33}$ J. Gwynfor Jones and Vivienne Larminie, "Bayly, Lewis, (c. 1575 - 1631)," Oxford Dictionary of National Biography OUP: 2004 and 2008. An example of his defense of double predestination is Practise, 235-38.

${ }^{34}$ Green, Print, 348-49 and 369. For Bayly on the Jacobean holidays, see Practise, 661-62.

${ }^{35}$ Veith, Reformation Spirituality, 30.

${ }^{36}$ Another text, cut from this chapter, that align with these viewpoints is Henry Valentine's 1635 Private Devotions, Digested into Six Letanies, which had gone through eleven editions by 1640. He lists in his duties at church, 118-27, the importance of hearing the word, praying, and displaying the "reference of thy body" through "bend[ing] thy knee." He also, 167-9, says to receive the sacrament kneeling and that there is "no gesture so suitable for prayer as kneeling."

${ }^{37}$ In addition to what I have written here on the frontispiece, see Dyck, 559-563, Ryrie, Being Protestant, 180-2, and Matthew P. Brown, "The Thick Style: Steady Sellers, Textual Aesthetics, and Early Modern Devotional Reading," PMLA 121.1 (2006): 75-78.

${ }^{38}$ See Dyck, passim. The 1611 KJV titlepage for the New Testament has the Tetragrammaton at the top of the page, but a lamb (not a flaming heart) sits atop the altar. The 1611 New Testament, on the other hand, uses the same Davidic altar frame as Cosin's Private Devotions and the Tetragrammaton rests in a fiery cloud above an altar with a flaming heart, flanked by two kneeling supplicants praying towards the name of God. 
39 Tessa Watt, Cheap Print and Popular Piety, 1550-1640 (Cambridge: CUP, 1993), 161, relates that the Teragrammaton was the most frequent image of the deity in this period, as a way to get around restrictions against depicting the deity.

${ }^{40}$ See variously, Practise, 320, 413, 610, 667, 871.

${ }^{41}$ Brown, 77. The specific Ephesians reference is probably 5:16 (KJV: "Redeeming the time, because the days are evil"). The reference to 1 Timothy 4:8 has anti-Laudian potential, but the manual does not support it. The engraver substitutes piety for godliness (KJV: "For bodily exercise profiteth little: but godliness is profitable unto all things, having promise of the life that now is, and of that which is to come). Matthew 25 is the parable of the 10 virgins.

${ }^{42}$ Ryrie, 180-2; Wilcox, Poems of George Herbert, 602. On faith, prayer, and fasting, see Tymme or Cosin above.

${ }^{43}$ Practise, 262, includes presumption as one of the seven "hinderances of Piety."

${ }^{44}$ See for instance Guibbory, Ceremony and Community, 28-33, for her discussion of Laudian "innovations" and the use of altar as Laudian.

${ }^{45}$ The italics are citations of Augustine, John 6:57, and John 12:2.

${ }^{46}$ See further, Practise, 664: "Though no man living is of himself worthy to be a guest at so holy a banquet; yet it pleaseth GOD of his grace to accept him for a worthy receiver, who endeavoureth to receive that holy mystery, with that competent measure of reverence that he hath prescribed in his word."

${ }^{47}$ Buckeridge's Passion Sunday sermon echoes Bayly's defense, though Buckeridge cites Augustine. External sacrifices desire internal sacrifices, an idea which Buckeridge defends through two scriptural examples, including Matthew 6-a marginal reference here in Bayly's text. Buckeridge, Passion Sunday, 12, cites Proverbs 23:26 "My sonne, give me thy heart" [and let your eyes delight in my ways] and paraphrases Matthew 6 as "God cares not for the outward, nay, hee loathes it, if the inward be wanting."

${ }^{48}$ Cum Romam venio, Jeiuno Sabbato: cum hic sum, non Ieiuno. Sic \& tu, ad quam sorte Ecclesiam veneris, eius morem serva, si cusqua[m] non vis esse scandalo, nec que [m] quam tibi. It is cited as "Amb. consil. / August. ep ad Ianuar." Cf. Herbert, A Priest to the Temple 92-3: "Contentiousnesse in a feast of Charity is more scandall than any posture;" see also Chapter Four below.

${ }^{49}$ In context, Fincham, 276-288, maintains that Custodians of Order were bishops (the sense of order derives, 277-8, from a 1626 consecration sermon by Cosin's) as based, 288, off a paraphrase of Book VII of Hooker's Lawes where "Hooker argued forcefully that the hierarchy should act as governors not preachers." Even in his quotation of Cosin, Fincham glosses over Cosin's declaration that "I come not here to preach down preaching; but this I wonder at, that preaching now-a-days should be counted our only office, as if we had nothing else to do." The Works of Bishop Cosin, vol. I, edited by John Henry Parker, (Oxford: 1843), 96.

${ }^{50}$ Of course, stirring up attention is by no means confessional. For example, Sparke, Crums of Comfort, sig. A4r advocates methods to stir up attention for prayer, which includes reading the Word and "Consider[ing] Gods glorious Majesty."

${ }^{51}$ E.g. William Perkins, The Arte of Prophecying (London 1607), whose "Analysis of the whole booke" (no page number, but appears after sig. A6) breaks down the text into interpreting the text and cutting it up to divide the application, understanding, and practice of the Word, which can be demonstrated through the spirit in word and gesture. More commonly cited is, 148, his "Order and Summe" of the method of preaching which is a four-fold method of reading the text, giving the sense of it, to offer useful points of doctrine, and apply them.

${ }^{52} \mathrm{Cf}$. Sparke's prayers before and after a sermon, invoking effectual listening and mindfulness, Crums, sig. F2r-F3r.

${ }^{53}$ See for instance McCullough, ed. Selected Sermons, 391-2, 401; on the popularity of Sternhold and Hopkins, see White, Tudor Devotion, 43. 
${ }^{54}$ Charles Herle (1597-1659) was at Exeter from 1612-15. Henry Tozer (1601-50) from 1621-23. Their texts are Charles Herle, Contemplations and Devotions on the Severall Passages of our Blessed Saviours Death and Passion, (London: 1631) and Henry Tozer Directions for a Godly Life: Especially for Communicating at the Lord's Table, (Oxford: 1628).

${ }^{55}$ Quotations are from Vivienne Larminie, "Tozer, Henry," Oxford Dictionary of National Biography, OUP: 3 January 2008. Green, Print and Protestantism, 292, categorizes him as Puritan. Ryrie occasionally cites this manual on communion but offers little commentary about Tozer himself. Neither cite Herle. Tozer refused a DD in 1646. The editor at A Puritan's Mind calls him a "puritan royalist." "Henry Tozer (1602-1650): A Puritan minister, and member of the Westminster Assembly," A Puritan's Mind, 2021. https://www.apuritansmind.com/puritanfavorites/henry-tozer-1602-1650/ (accessed February 17, 2021).

${ }^{56}$ Vivienne Larminie, "Herle, Charles," Oxford Dictionary of National Biography, OUP: 25 May 2006, para. 5, says he played a "conciliatory" role at the Westminster Assembly. For examples of his politics, see Sechler, Michael J., and Janelle Greenberg, "'There is Scarce a Pamphlet that doth not Triumph in Bracton': The Role of 'de legibus et consuetudinibus angliae" in Stuart Political Thought," History of Political Thought 33.1 (2012): 25-54, esp. 42-49, or Edward Vallance, "Preaching to the Converted: Religious Justifications for the English Civil War," Huntington Library Quarterly 65.3/4 (2002): 395-419, esp. 410-11.

${ }^{57}$ With the first contemplation being focused on "His bloody sweat in the Garden" it would be interesting to compare this work with Herbert's Passion Week poems in The Temple.

${ }^{58}$ For example, Directions, 155-160, includes set meditational prayers that are preparative for the sacrament. See Garrett, 345-52, esp. 349 on the lack of contention between "Puritans and Anglicans" on set prayer in private settings, or Peter Lake, "Calvinism and the English Church 1570-1635," Past \& Present 114 (1987): 32-76, esp. 43-4. As we will see below, this plays out a little differently once the Westminster Assembly publishes the Directory for Public Worship. ${ }^{59}$ Andrewes, among several others, refer to sacraments as "conduits of grace." See e.g. his 1616 Whitsunday Sermon, XCVI Sermons, 696: "the Word, the Sacraments, the Keyes, are unto others the conduits of grace, to make them fructifie in all good works."

${ }^{60}$ In context, this passage appears in the chapter examining repentance, talking about a confession that comes from the heart and the mouth - but they should be about the individual and not the censuring of other men.

${ }^{61}$ Later, 144, Tozer reiterates the act of "sit[ting]" at the Lord's Table, which draws on typical Calvinist nomenclature.

${ }^{62}$ Also 63: Paul "biddeth every man to trie and examine himself."

${ }^{63}$ Or, as Ryrie, Being Protestant, 402-3, phrases it, the stirring up "offered a way of spreading the faith while avoiding the awkward business of talking about it. Believers could simply focus on their own holiness and hope that would do the trick."

${ }^{64}$ Ryrie, Being Protestant, 232, citing Directions 169-70.

${ }^{65}$ The Directory of Public Worship has not been well received by those with a strong Anglican bias. In his history of the church, J. Shackelford Dauerty, "The Recovery of Worship (continued)," Journal of the Presbyterian Historical Society (1943-1961) 37.3 (1959): 188, argues the Directory put the church in the "Dark ages" of worship with its having "scunnered at" set prayer.

${ }^{66}$ E.g., Andrewes, Institutiones Piae, 3: "And as we have Gods precept and promise, to provoke us to Pray unto him, so also have we the Example (not only of all the Saints of God, but ) of Christ Jesus himself, who while he was co[n]versant in the flesh upon Earth . . . often, and earnestly prayed." Or 28-30: "Because that our Saviour Christ hath taught us how to pray, and hath put the very words (as it were) into our mouthes ... Yet let not any man thinke, that our Saviour prescribed us this prayer, as that we should use no other."

${ }^{67}$ Lest I be accused of privileging Laudian attitudes, this combination is seen in the works of William Perkins, a puritan-leaning defender of preaching. A Golden Chain, (London: 1591), sig. 
G6r-v: "First, in the ministers, who ought to administer all thinges belonging to Gods worship, according to his word. . . Secondly, in the rest of the assemblye whose duety is in praying unto God, in hearing the word preached and read, and in receiving the Sacraments. To behave themselves outwardly in modesty and without offence. 1. Cor. 14.40. Let all things be done honestly, and by order. Inwardly, they must take heed, that their harts be well prepared to serve God." He continues to describe fasting as a "help and furtherance[] of true woorshippe" and elsewhere repeats the call for the church's assembly to hear the Word preach, receive the Lord's Supper, and join together with the congregation in public prayer.

${ }^{68}$ The full dedicatory title makes clear that Herle writes to an estimable patron: "To the right Honorable James Lord Strange, Baron of Knocking, Lord Lieutenant of the Counties Palatine of Lancaster, and Chester, and of the Cisiter of Chester, and County of the same, and Chamberlaine of Chester afore said. Lord of the isle of Man, Knight of the Honourable Order of the Bath. Heire apparent to the Right Honrable William Earle of Derby, his very good Lord and Master. Herle expresses no explicit presumption for preferment or favor.

${ }^{69}$ Herle's italics preserved. See also the discussion of Herbert's "Business" in Chapter Four. ${ }^{70}$ S. K. Baskerville, "Puritans, Revisionists, and the English Revolution," Huntington Library Quarterly 61.2 (1998): 151-71, esp. 169. He cites Herle's Ahab's Fall by his Prophets Flatteries (London: 1644), 9-10, which blames the Arminians (and others) for "all our present miseries." In context, Herle does not provide a citation for this diminishing of God's glory. 


\section{Chapter Four: Laudianism and The Temple}

"The point is, the Anglican Church of Herbert's day, in its main stream, was both ceremonial in its liturgy and Calvinist in its theology. The via media of the Church of England was largely then a liturgical goal ... After the Restoration, Calvinism and main line Anglicanism would go in different directions, but Herbert's own religious milieu resists the later categories. . Herbert's image as the archetype of Anglican piety need not be challenged in "Protestant" readings of his poetry; it is the nature of that Anglican piety, rather than Herbert's obvious religious conformity, that sometimes needs a revisionary treatment."1

At this point of the project, a number of consistencies across the primary texts appear, regardless of genre. All the authors were educated ministers united under umbrella of English Protestantism, with some rising high in ecclesiastical ranks, writing or preaching to laypeople of various stature. Several wrote to requite a gap, such as the perception of improper worship practices or the dearth of English devotionals. Each text has a serious didactic veneer guiding the reader to certain spiritual or edifying ends. These elements do not change as we turn to George Herbert's lyric poetry. Like the previous authors, Herbert was educated, ordained, and could have found success at court or Parliament had he not retired to the country on account of his health. The para-textual materials of The Temple and The Church-Porch make clear that the collection of poems can be read for self-improvement, in line with Sidney's proclamation that the end of poetry is to instruct and delight or the devotionals on proper behavior in and outside the church. However, poetry offers new challenges absent from the prose works. For one thing, prose is relatively stable. While there are certain affordances in whether to approach a sermon sa text or oration or comparing a devotional treatise to a manual of set prayers, individual works within those genres are, on a formal level, fairly consistent. Herbert's poetry, on the other hand, offers "the simultaneous sense ... of order and randomness" in its organizational structures and variety in verse forms. ${ }^{2}$ Aside from the 
rhetorical flourishes in the sermons, the poetic craft offers a level of eloquence and sophistication hitherto unseen. Moreover, the lyrics in The Temple are more personal than any writing we have encountered so far. Although the occasional poem addresses contemporary or ecclesiastical concerns (e.g., "Lent"), most lack political or polemical impetuses and some directly invocate God in intimate conversations or hymns, where the didacticism is less about explicit models of behavior and more about religious selfreflection. For poems that do raise theological questions, Herbert avoids easy confessional classification, with his moderation (see his expression of the via media in "The British Church") making him appear both puritan and Anglican, which has led some to argue that Herbert's verse is more about religious experience than doctrine. ${ }^{3}$ So how then are we to assess such a complexly irenic poet?

The stereotypical opening for essays on Herbert's religion goes something like this: at the start of the twentieth century, freshly cognizant of the Oxford Movement's revisionism, scholars viewed George Herbert as the paragon of Anglicanism. His poem "The British Church" renders an Anglican via media that situates the English church halfway between Geneva and Rome. Rosemund Tuve, Stanley Stewart, and Joseph Summers argued the importance of Herbert's medieval, Anglo-Catholic, or High-Church roots. On the other hand, Barbara Lewalski's Protestant Poetics, itself a response to Louis Martz's book on the influence of Catholic meditative practices on English poetry, reclaimed the Protestantism of English poets, who drew their inspiration from the Bible. Lewalski's work inspired a slew of scholars to unearth Herbert's connections to Calvin and Calvinism, many of whom framed the Calvinist influence as antithetical to the Anglo-Catholic. ${ }^{4}$ Common in these essays is a delineation of scholars who claim Herbert 
"on the Calvinist side in theology" or "aligned with the proto-Laudians." 5 The paradox at the core of this dichotomy is that the identification of this "precise doctrinal allegiance" eschews one side for the other while both are clearly present. ${ }^{6}$ The tradition of competing claims of religious identity began shortly after Herbert's death. One byproduct of this process has led some scholars to conceive in Herbert a "sacramental puritanism" to reconcile his use of ceremony and the external elements of the church with his intensely personal lyrical poems. ${ }^{7}$ Although Gene Veith has recognized that "this dichotomy between Puritans and Anglo-Catholics, assumed by countless literary historians . . . is wrong," his call for a reinterpretation of Anglicanism has largely gone unheeded by said literary historians. ${ }^{8}$ My work offers a corrective to the binary reading of Herbert.

I argue that a more inclusive view of Laudianism helps undo the prevalence of this dichotomy, where neither the Laudian nor Calvinist tropes preclude the other. ${ }^{9}$ An inclusive Laudianism maintains a symbiotic relationship between the inner and external markers of worship, both within the worshiper and the physical accoutrements of the church: the external helps inspire internal devotion (as seen in "Church-Monuments"), and it is only when one's internal senses are attuned to the holy that the external exudes reverence (as hinted in "Businesse"). It is possible Herbert inherited this attitude from his life-long friend Andrewes, whom he initially met at the Westminster School, where the latter was dean. Like the elder bishop, Herbert largely avoids controversy and promotes a beauty of holiness not for the sake of church decoration but displaying reverence before God. ${ }^{10}$ In addition to the Laudian para-texts of The Temple, likely added by Nicholas Ferrar, I make much of Herbert's use of sequences, especially in the first half of The Church, to argue Herbert's Laudian engagement with and liturgical conformity to the 
BCP. ${ }^{11}$ While The Church-Porch and Church Militant (the two sections surrounding The Church in The Temple) have their own Laudian markers - such as the emphasis on pious doing or the church's lineage and tradition, respectively - none perhaps are so prominent as the various sequences within The Church, which include the sacrificial and Eucharistic opening, the liturgical year, church adornments, and the apocalyptic sequences that emphasize both the communal and individual responsibilities of a pious Christian. Herbert employs multiple sequences, and several overlap. ${ }^{12}$ Conformity to the liturgy and official church practice are at the heart of Herbert's Laudianism and serve as the starting point for one's personal, devotional relationship with God. ${ }^{13}$

Based on the Williams and Bodleian manuscripts, ample evidence suggests Herbert intentionally ordered the individual poems and placed them in the larger tripartite structure of The Church-porch, Church, and Church Militant. The Laudian veneer of the work stands on less stable authorial ground. By veneer, here I refer specifically to the title, the title-page epigraph, and epistolary The Printers to the Reader, as opposed to those poems with an apparent disjunction between title and body, discussed below. Usually, Nicholas Ferrar and the community at Little Gidding is to "blame" for these editorializations. ${ }^{14}$ Regarding the title, there is no manuscript evidence that Herbert himself intended to use The Temple, which has far more sacrificial, ceremonial, and priestly overtones than church. ${ }^{15}$ The title-page's epigraph of Psalm 29:9 ("In his Temple doth every man speak of his honour") works on multiple levels. In the most literal sense, The Temple - which Herbert dedicated to "Divine Majesty"-is full of poems addressing God's relationship to man. ${ }^{16}$ In an Andrewesian sense, the temple, as house of God, demands reverence (honour), which is ever-present throughout these devotional lyrics. 
The Printers to the Reader, possibly penned by Ferrar, paints Herbert's biography as the meeting ground of public and private devotion, which The Church-porch echoes. The letter states, "His obedience and conformitie to the Church and the discipline thereof was singularly remarkable. Though he abounded in private devotions, yet went he every morning and evening with his familie to the Church; and by his example, exhortations, and encouragements drew the greater part of his parishioners to accompanie him dayly in the publick celebration of Divine Service." This approbation exemplifies both the devotions celebrating corporate liturgy's bringing together of minister and congregation in prayer and the parson's own piety. Herbert's pious example is one worthy of emulation and prepares the reader for the moral admonitions of The Church-porch. With the additional statement that "he did earnestly endeavor the resignation of an Ecclesiastical dignitie" in order to be an "instrument for reedifying of the Church belonging thereunto," the letter presents Herbert as a prebend whose initial church renovation encouraged ordered and decent worship - words that Herbert himself used in The Country Parson. ${ }^{17}$ Thus, before the reader glances at the first poem in The Temple, they are presented with the editors' portrait of a Herbert who conforms to the discipline of corporate church worship.

I. "The Dedication" and The Church-porch: Ceremonial Preparation?

Only one of the 166 poems in The Temple appears outside of its tripartite division. "The Dedication" mirrors the stanza form of the subsequent "The Church-porch," which suggests thematic similarity. The poem consists of a quatrain, an apostrophe to God, and an epigrammatic couplet, addressing the didactic value of the verse for the reader who seeks moral instruction. The poem reads: 
Lord, my first fruits present themselves to thee;

Yet not mine neither: for from thee they came, And must return. Accept of them and me, And make us strive, who shall sing best thy name.

Turn their eyes hither, who shall make a gain:

Theirs, who shall hurt themselves or me, refrain. (1-6)

The reciprocal, paradoxical nature between God and poet features strongly throughout The Temple. Though the chronology of when Herbert wrote specific poems is disputed, "first fruits" could only be read literally if considering the poet's English verse exclusively of his Latin poetry, which was published in 1627 after his mother's death as Memoriae Matris. Wilcox annotates "first fruits" as being both legalistic, what the church owes to the crown, and biblical, referring to the annual Jewish sacrificial offering to God. ${ }^{18}$ In the latter sense, the offering predicts the reciprocal relationship between divine and poet that the opening sequence questions. The divine can create perfection. Tainted by sin, humanity's works falter. While there exists a certain egoism in the relative clause "who shall sing best" (rather than "any who shall sing"), the imperative "make us strive" suggests the need for practice and improvement. It is not until "Easter" - a poem wholly about song and celebration rather than soteriology - and "Easter-wings" that the poetspeaker begins to show confidence in his work, which reflects the salvific union between sinner and divine through Christ's resurrection. Before those poems lies the beginning of the poetic drama where the speaker questions the quality of his actions and art in offering them as sacrifices to the divine.

The closing couplet of "The Dedication" mirrors the moralistic tenor of The Church-porch with its direct call for those who seek to improve themselves, spiritually, to direct their gaze to Herbert's book of poems. Herbert's wordplay here is impressive. With "make a gain" recalling the legalistic and pecuniary connotations of "first fruits" 
adding to the generative "make again," the reader has multiple options for spiritual edification through reading and returning to these verses. ${ }^{19}$ The repeatable potential of the devotional act has a certain liturgical ethos, as the language of the poetry so often draws from and recommends partaking in both. In the last line, "refrain" most clearly means halting someone from reading (or having the reader exert that self-control), but it puns ironically with singing, as refrains are repeated choruses of hymns - which, though present in The Temple, would be unavailable for those not seeking improvement or edification. This quest for edification raises questions of genre. Though Herbert will directly acknowledge this in the first stanza on the following page, here he associates his poetry with a certain type of devotional practice, as found in reading devotional manuals and reading - or hearing - the Word. While the full ramifications of this experience are elucidated more prominently in The Church poems, the moral preparation for such practices begins in The Church-porch.

To offer one typological interpretation of The Church-porch's relationship to The Church, the former functions as the ceremonial law to the former's gospel. ${ }^{20}$ That is, to follow the architectural metaphor, as the reader prepares to enter the church doors, they first must reflect on their own behavior to enter into a confessional state before they come face-to-face with God's sacrifice - whether metaphorically through "The Altar" (the first poem of The Church) or with the physical altar reminding them of Christ's sacrifice and, potentially, communion. Critics have advanced these meditational comparisons along with other generic interpretations, such as the suggestion that the opening poems are "a sort of sermon based on practical divinity." ${ }^{21}$ This genre bending comes from Herbert's first stanza of "The Church-porch," but it opens the door for other symbolic 
interpretations, especially if these are steps in pre-Eucharist confession and meditation. In line with the sermon-service controversy explored throughout this project, Herbert's stanzas stand in for the pre-service sermon (an answer to the complaint against those that leave the church after the sermon but before the liturgical service and communion - a viewpoint my reading of "The Invitation" supports). Full of pithy epigrams, The Churchporch exhorts readers to church-worthy behavior. ${ }^{22}$ Inside, The Church explores the ceremony of the service and what the service itself represents - the Christian's relationship with God, on earth, in communion, in banqueting, and in salvific reunion.

Two poems comprise The Church-porch section, the poem "The Church-porch," subtitled "Perirrhanterium," and the shorter "Superliminare." ${ }^{23}$ The latter poem draws attention to the physical movement throughout the temple and privileges a Eucharistic reading. In its entire eight lines, the poem reads:

Thou, whom the former precepts have Sprinkled and taught, how to behave Thy self in church; approach, and taste The churches mysticall repast. Avoid profanenesse; come not here: Nothing but holy, pure, and cleare, Or that which groneth to be so, May at his peril further go. (1-8)

The first stanza (the two are divided by a line, as represented above) recalls and sums the previous poem, where the "former precepts" are both action ("sprinkled") and instruction ("taught"). From the past-tense recalling, the poem shifts to an open, present-tense invitation to participate in the church's meal: the Eucharist. The second stanza acts as another precept, the commonplace encouraging of holy behavior and avoiding profaneness. Wilcox notes that the line has contested punctuation and capitalization, including an apostrophized personification that changes the admonition from the reader 
to "Profanenesse." She also cites both the OED's definition of it meaning unholiness and contempt for the sacred as well as the etymology of "pro/fano" meaning before or outside the temple. ${ }^{24}$ The etymology reflects the Andrewesian beauty of holiness in that the temple is the site for holy and pure behavior. Regardless of reason for coming to the church, holiness need be present in the believer. Though "groneth" predicts "Sion's" potential anti-Laudian rejection of physical adornment, there is nothing ornate in this poem, aside from the title suggesting a physical sign above the doors of a church.

Throughout the two poems of The Church-porch is a consistent stress on actions, making clear to the reader what they should do. "Church-porch: Perirrhanterium" contains concise proverbs, enumerating them in a long list on proper behavior against sinful actions, probably intended for a young, courtly man or Herbert's brother Henry. ${ }^{25}$ The proverbs are self-contained in stanzas, though some themes permeate multiple stanzas. ${ }^{26}$ Similar to Herbert's admonition and citation of 1 Corinthians 14 in The Country Parson (see note 17), his first stanza lays out the edifying and instructional value of the poem:

Thou, whose sweet youth and early hopes inhance Thy rate and price, and mark thee for a treasure; Hearken unto a Verser, who may chance Ryme thee to good, and make a bait of pleasure. A verse may finde him, who a sermon flies, And turn delight into a sacrifice. (1-6)

In terms of genre, the speaker seeks to replace the instructional value of the sermon with that of poetry. With the stanzaic proverbs, each stanza is a sort of epigram-as-sermon, with each set of six lines containing some type of axiomatic statement of good behavior and practice. ${ }^{27}$ The humility topos takes an ironical spin with the speaker's identification as a "Verser" rather than a preacher because a "verser" connotes a second rate poet or 
swindler. ${ }^{28}$ Both of these ideas manifest themselves elsewhere in the poem, when the speaker says "All worldly thoughts are but theeves met together / to couzin thee" (42425) and later advises parishioners not to judge or criticize a poor preacher (427-444). As we will see in line 409 ("Resort to sermons, but to prayers most"), this is not a criticism to do away with sermons, as some scholars interpret Laudian critiques of sermoncentered piety to be, but the preacher's bugbear of the inattentive auditor. ${ }^{29}$ The speaker's intent to "Ryme thee to good" recalls the instructional role of poetry, but also speaks to the same didactic goal of sermons and devotional literature, provided the reader acts appropriately. ${ }^{30}$

The second stanza of Perirrhanterium shows the importance of holy behavior informing the actions individuals take, which could be read in the vein of Andrewes. It reads:

Beware of lust: it doth pollute and foul Whom God in Baptisme washt with his own blood. It blots thy lesson written in thy soul; The holy lines cannot be understood. How dare those eyes upon a Bible look, Much lesse towards God, whose lust is all their book? (7-12)

Mindful of the poem's subtitle, this stanza's reference to baptism is the poem's only explicit mention of the sacraments. Though the reference to Christ's blood invites comparison to the Eucharist, there is no sense of renewal or sacrifice in this stanza as elsewhere in The Temple. "Superliminare" reiterates these themes, through drawing attention to the act of sprinkling and the scant allusion to the Eucharist via "mysticall repast." With this in mind, "The Church-porch" does not endorse a Laudian or sacramental ceremonialism, but the poem "does resemble the language exchanged in the ceremonies ... that took place in the church porch" and "does not treat the . . internal 
and external as though they were irreconcilable categories." ${ }^{31}$ These ceremonial actions are subsumed into the broader category of pious behavior in general. While three lines focus the reader's sight on reading the Bible, the last line orients that attention to God himself, a redirection sympathetic of wanting holy and reverent behavior inside the church to reflect God's presence.

The closest Herbert comes to endorsing a Laudian sense of conformity in this poem is in his promotion of public prayer, here valuing it more than private prayer. In this case, and perhaps typical of Herbert's doctrinal elusiveness, public prayer refers literally to joint prayer, rather than the liturgical service or the Eucharist. ${ }^{32}$ Herbert writes that public prayer offers more potential through its communalism:

Though private prayer be a brave designe, Yet publick hath more promises, more love: And love's a weight to hearts, to eies a signe.

We all are but cold suitors; let us move

Where it is warmest. Leave thy six and seven;

Pray with the most: for where most pray, is heaven. (397-402)

Wilcox glosses "brave designe" as "worthy intention," noting the similarity to line 101's "Studie this art, make it thy great designe" to which she includes the OED's definition of design as "purpose." Brave also has a connotation of "finely-dressed" or showy. ${ }^{33}$ Though Herbert is against overt ostentation, substituting "showy sketch" suggests potential in set prayers, which is not surprising given his love for liturgy, as the formal prayers are what provide the basis for communal prayer. ${ }^{34}$ Inside The Temple, "Prayer" (I) confirms these views, as Prayer is "the Churches banquet" and "Exalted Manna" to share among believers in a communal feast $(1,10) .{ }^{35}$ The last line of the couplet hints at a later couplet that pairs behavior with location: "Look to thy actions well: / For churches are either our heav'n or hell" (425-26). Church is the location for common prayer and 
communing together is heavenly, which seems to imbue a salvific element onto public prayer.

Before Herbert concludes that church can be either heaven or hell for an individual, he first turns to the proper behavior inside the church. Conforming to an Andrewesian brand of liturgical observance, Herbert's pattern for behavior is naturally reverent and humble:

When once thy foot enters the church, be bare.

God is more there, then thou: for thou art there

Onely by his permission. Then beware, And make thy self all reverence and fear.

Kneeling ne'er spoil'd silk stocking: quit thy state.

All equall are within the churches gate. (403-408)

The OED cites this poem as an example of bare meaning "bare-headed;" the reference in "The British Church" of Geneva as the naked extreme suggests bare-headed to be a better gloss than empty or naked (24-25: "She . . nothing wears"). ${ }^{36}$ However, combining a deferential bare with "make thy self all reverence and fear" leaves the reader with an Andrewesian beauty of holiness, tendering these attributes towards God's presence ("God is more there, then thou"). As such, all are equal before the Lord and, "within the churches gate," kneeling is the appropriate gesture of humility, regardless of one's social standing. Herbert does not specify whether kneeling refers to prayer or communion, but the differentiation may not matter has "Prayer" (I) equates prayer with the church's banquet. Regardless, as with the Avant-Garde Conformists, gesture reflects propriety in all forms of worship, regardless of social status. ${ }^{37}$

As the poem's first stanza suggests, a strong interplay exists in this poem between sermons and poetry in terms of the reader's edification. As a later stanza makes clear, 
however, sermons or exhortatory poems are not the height of devotion. As worshippers should come to the church to pray, sermons should likewise stir them to further prayer:

Resort to sermons, but to prayers most:

Praying's the end of preaching. O be drest;

Stay not for th' other pin: why thou hast lost

A joy for it worth worlds. Thus hell doth jest

Away thy blessings, and extreamly flout thee,

Thy clothes being fast, but thy soul loose about thee. (409-414)

"Praying's the end of preaching" echoes Bayly's instructions for sermon-hearing and fulfills Lake's avant-garde prescription that "Prayer was ... the natural accomplice of preaching. ${ }^{38}$ For Herbert, prayer is active, so resorting to sermons is an active exercise one that draws on two meanings of resort: not just the directing of one's attention towards sermons and prayers, but also to turn to something for aid or "the means to an end" in "adopt[ing] a course of action." ${ }^{39}$ In this way, Herbert's view on sermons aligns with Laud's, who thought sermons "were not properly worship but designed to teach 'faith and obedience, and how we are to pray and give worship to" God. ${ }^{40}$ Prayer is a constant thing, which explains the penultimate stanza's reference to constant reflection in prayer to both dress and undress the soul. Here, Wilcox glosses "drest" as "metaphor for spiritual preparedness through prayer," though the following lines talk away excessive concern for physical appearance during prayer - perhaps an echo of "kneeling never spoil'd stocking" in the previous stanza. ${ }^{41}$ The relative inattention to appearance should be unsurprising, given both the emphasis in "The British Church" on mean appearance, and the earlier denunciation of stately dress: "I care not though the cloth of state should be / Not of rich arras, but mean tapestrie" (269-70). Dress need not distract from the Christian duty to prayer. Ostentation serves no worthwhile end when it does not reflect the state or status of the soul itself. The next stanzas reiterate this idea, shifting the 
attention of the eyes inward (415-420) and banishing vain and idle thoughts (421-26) two common distractions during sermons, which are the focus of the following three stanzas (427-444) admonishing the reader not to judge or jest at preachers, for even poor or convoluted sermons have value to the hearer, as Bayly also wrote. For that value to accumulate, however, the hearer must reflect and behave appropriately.

The last two stanzas of "The Church-porch" offer two separate conclusions, with one based in pious reflection and the other in broad, moralistic platitudes that may be secular in nature. In terms of religious behavior, the penultimate stanza seems to be the actual conclusion, as it focuses on daily ritual self-examination of prayer. The two stanzas together read:

Summe up at night, what thou hast done by day; And in the morning, what thou hast to do. Dresse and undresse thy soul: mark the decay And growth of it: if with thy watch, that too

Be down, then winde up both; since we shall be Most surely judg'd, make thy accounts agree.

In brief, acquit thee bravely; play the man. Look not on pleasures as they come, but go. Deferre not the least virtue: lifes poore span Make not an ell, by trifling in thy wo.

If thou do ill; the joy fades, not the pains

If well; the pain doth fade, the joy remains. (451-62)

The first stanza has strong similarities to the types of prayers invoked in the Morning Prayer (Matins) and Even-Song BCP prayers. Wilcox notes the similarities to The Temple poems "Mattens" and "Even-song," the latter of which has a timepiece motif to match the winding of the watch in lines 454-456. ${ }^{42}$ While the imperatives of summe and (un)dresse reflect the importance of prayer (while continuing the dressing the soul metaphor), the winding of the watch to make accounts agree gives the poem a recursive sense of continuing the financial metaphor of price and treasure from line 2. However, rather than 
financial gain, Herbert focuses on the spiritual growth of the soul throughout. Because of the emphasis on religious growth, the final stanza, in comparison, seems to be an odd summation of the poem. Though "play the man" seems like line 121 's "Doe all things like a man, not sneakingly," the emphasis on pleasure, virtue, joy, and pain, could equally apply to a secular or religious life. "In brief" seems to signal a second conclusion, as the preceding stanza works as a spiritual recounting of the previous 75 stanzas. However, to consider The Church-porch as a whole, the presence of "Superliminare" returns this to an explicitly Christian frame of reference, as it summarizes "The Church-porch" as a group of precepts to be learned, as befitting a catechist. Thus, the secular couplet informs the preparation for entering The Temple to join the Christian "repast" - both the feast of common prayer and of communion. The final line of "Superliminare" also recalls the earlier lines of 425-26: "Look to thy actions well: / For Chuches are either our heav'n or hell." It is the latter option that gives credence to "May at his peril further go ("Superliminare" 8). With a properly prepared mind and body, the reader can enter into The Church, where one first sees the altar, beginning the meditational sequence on Christ's sacrifice.

II. Inside The Church: Holy Week, Liturgy, and Preparing for the Sacrament

When stepping into The Church from The Church-porch, one encounters less axiomatic instruction and instead faces a devotional mood where the main action is selfreflection. The first poem the reader sees is "The Altar," which functions like a second dedication or title page, gilding The Church with a sacrificial ethos that permeates all 161 poems up to "Love (III)," while also kickstarting the initial poem sequences in this part of 
The Temple. ${ }^{43}$ Many of the opening poems meditate on the events of Holy Week, the last week of Lent. A Laudian reading of this liturgical season would naturally culminate with the sacraments, as it is Christ's sacrifice and resurrection that underscore sacramental theology. I explore that culmination in the next section. Here, I focus on the sacramental preparation, as the meditations seem to imply a need for confession and pondering the sinner's relationship to Christ and God, a reflection of the acts laid out in the $B C P$ 's Communion service. $^{44}$

It seems impossible to approach "The Altar" without drawing attention to the poem's shape. While the representation of the altar is itself paradoxical - the poem's identification of the heart as a broken altar contradicts the text's physical shape Herbert's ironic use of imagery, here and throughout The Temple, reflects the fallibility of an exclusive Calvinist/Ceremonial binary. The poem's shape resembles a Jewish altar, suggesting a more sacrificial than Eucharistic ceremonialism, and has alternatively been read as a Corinthian column or a capital $I .{ }^{45}$ The mere appearance of an image is an affront to the most radical puritans, but Herbert admits some use of images in The Country Parson and the title-pages in the previous chapters admits some Calvinist potential in engravings. ${ }^{46}$ At the same time, the presence of two altars undercuts the value of the image itself. The opening lines make clear that the speaker creates an altar other than the one represented on the page: "A broken ALTAR, Lord, thy servant reares / Made of a heart" (1-2). The broken heart echoes Psalm 51, the Penitential Psalm that has appeared on almost every title-page explored in this project. ${ }^{47}$ Hannibal Hamlin argues that Christians saw this psalm as "a prophesy of the substitution of the Gospel for the Law, replacing the sacrifice of animals with the sacrifice of Christ and the sacrifice of the 
penitent's heart," which is a view that would support The Church transitioning away from the ceremonial observance of The Church-porch. ${ }^{48}$ The poem's emphasis on "thy servant" and the ineffectiveness of "no worksmans tool" shows the inability of mankind to render a functional altar on their own, evoking original sin and the fallibility of man (1, 4). As in "The Dedication," where the first fruits are both the speaker's and God's, a union of human and divine is needed. The speaker makes this appeal in the closing couplet: "O let thy blessed SACRIFICE be mine, / And sanctifie this ALTAR to be thine" (15-16). This cry allows the reader to claim Christ's sacrifice and uses that sacrifice to sanctify the workmanship of his servant. Sequentially, this union does not happen until the Easter poems, but the broken stones of the human speaker become a motif for poetry and human worship throughout. ${ }^{49}$ If the poem endorses Laudian views beyond its shape and implicit invocation of ceremony, it is in the need for one to be penitent and contrite (or humble) in order to join with the divine in religious acts.

While the references to Psalm 51 in "The Altar" show an initial liturgical or biblical undercurrent to Herbert's verse, the next poem, "The Sacrifice," embodies the liturgy in Christ's sacrifice and orients the sequence in the Thursday and Friday of Holy Week. The opening lines of the poem echo Lamentations 1:12 (KJV: "Is it nothing to you, all ye that pass by? behold, and see if there be any sorrow like unto my sorrow, which is done unto me"), which was part of the Sarum Use missal's readings for the end of Holy Week:

Oh all ye, who passe by, whose eyes and minde

To worldly things are sharp, but to me blinde;

To me, who took eyes that I might you finde:

Was ever grief like mine? (1-4) 
The speaker of the poem is Christ, who ends each stanza in a litany-like refrain of "Was ever grief like mine" (with only two variations in 63 stanzas: when Herbert cuts short Christ's "My God, My God [Why have you forsaken me]" in lines 215-16 and the final line after Christ dies, 252). With Christ's voice, the readers have both a scriptural and divine injunction to point their eyes on Christ's sorrow - here on the cross. If literal, the eyes would be oriented as if to a crucifix. ${ }^{51}$ The apostrophe exhorts the reader to reflect on themselves and on Christ. The poem repeats the allusion in lines 201-03: " $O$ all ye who passe by, behold and see; / Man stole the fruit, but I must climbe the tree / The tree of life to all, but onely me.” This repetition emphasizes Christ's salvific role against original sin and his transformation of the cross from a symbol of death to resurrection. While this eventually leads to Christian joy, the poem emphasizes the inner grief and pain of the experience. ${ }^{52}$ Sequentially, Christ's agony is requited through the joy of "Easter" and "Easter-wings" (both of which scrimp on the soteriological importance of the occasion). While scholars disagree whether Herbert participates in or critiques Catholic meditational and Eucharistic practices, the poem invokes the sacraments in lines 7 (“except I give them bread") and 246-7 ("For they will pierce my side, I full well know; / That as sinne came, so Sacraments might flow"). ${ }^{53}$ The sacramental allusions that call for the reader to participate in the meditation give the poem a certain Laudian gloss that balances the inner reflection with liturgical participation.

The poem intersects with two other Laudian themes seen elsewhere in this project, the power of the state (in a non-Erastian sense) and kneeling. The stanzas recounting Christ's trial contain potentially ironic judgments of earthly and heavenly authority. Christ, presumably the ultimate heavenly authority, here submits to the earthly: 
Herod in judgement sits, while I do stand;

Examines me with a censorious hand:

I him obey, who all things else command:

Was ever grief like mine? (81-84)

The irony here is not that Christ obeys Herod's earthly authority (cf. "render unto Caesar what is Caesar's"), but the lack of context around "all things else command." It is the refrain of grief that lends this an ironic reading. Christ should be obeying the commands of the heavenly father rather than the earthly Antipater, but the submission that leads to his death causes him grief. ${ }^{54}$ The question at this point is what does the believer - or the English Christian - do in reading these lines. Does obeying the earthly commander lead to grief? Is Christ endorsing following the earthly Herods in their lawgiving? A later stanza may offer insight. After distinguishing himself from the "seditious murderer" as the "Prince of peace" (118-9), the speaker says, "Why, Cesar is their onely King, not I: / He clave the stonie rock, when they were drie; / But surely not their hearts, as I well trie" (121-3). ${ }^{55}$ This line has been interpreted both ironically, continuing the thematic repetitions that the Jews do not recognize who they are condemning, where Christ is the true king, and straightforwardly, as Christ answers Pilate that he is not an earthly king. ${ }^{56}$ The second line's allusion to Moses suggests mortal leaders are, like human sacrifices, insufficient for the soul's survival. The third line, an echo of themes in "The Altar," gives credence to the ironic reading where Christ, as spiritual king, supersedes the importance given to earthly kings. The lack of a strong statement precludes reading this poem as an endorsement of the established church, even if Herbert makes use of its traditional liturgy.

Another area where this poem offers an ambiguous presentation of a mainlined Laudian position is on kneeling. "The Sacrifice" offers an ironic endorsement of 
kneeling. In the midst of the stanzas that show the Jews mocking and striking Christ, the speaker identifies those who mockingly kneel to Christ:

They bow their knees to me, and cry, Hail king:

What ever scoffes or scornfulness can bring,

I am the floore, the sink, where they it fling:

Was ever grief like mine?

Yet since mans scepters are as frail as reeds...

I, who am Truth, turn into truth their deeds:

Was ever grief like mine? $(173-77,180-81)$

The first excerpted stanza renders the scriptural basis for this kneeling into verse, Matthew 27:29 (KJV: "And when they had platted a crown of thorns . . . they bowed the knee before him, and mocked him, saying, Hail, King of the Jews!'). Line 180, while scriptural (John 14:6, KJV: "Jesus saith unto him, I am the way, the truth, and the life"), does not stem from the account of the crucifixion. It is, however, key to interpreting this moment. Wilcox annotates the line "Even as he is mocked, Christ shows up the truth of human frailty" with reference to line 177 ("scepters frail as reeds"). ${ }^{57}$ In a preceding stanza, the reeds “strike my head, the rock from whence all store / Of heav'nly blessing issue evermore" (171), which is itself an allusive echo of the struck stone in line 122. In context, the deeds include all the scornful acts. So, while "They" are bowing their knees, the truth is that, despite intentionality (in this case), kneeling is a pleasant action when done to the Lord. The action corresponds to how Philippians 2 portrays the gesture, where "every knee shall bow" and "every tongue should confess" the glory of Jesus through his crucifixion. ${ }^{58}$ Of course, Herbert includes this because it is biblical and an act of worship; he does not politicize it further or contextualize it as a Eucharistic or prayerful act. Without the context of the second stanza, the passage could be interpreted 
as being critical of kneeling to worship, but the second stanza inverts the criticism to show that kneelers act reverently.

The interplay between reverent act and intention features prominently in the subsequent poem, "The Thanksgiving," in which a non-Christ speaker responds to the events of "The Sacrifice." The initial tone comes off as if the speaker were a seventeenthcentury practitioner of the Prosperity Gospel. ${ }^{59}$ The opening couplets of the poem recap of several of the themes of the preceding poem, which literally "preventest me" (4): it includes apostrophes to the "King of grief" and "of wounds" before asking if "shall I weep bloud?" or "be scourged" (1-7) as acts of thanksgiving for Christ's sacrifice. The limping meter of the elegiac couplets (pentameters followed by tetrameters) hint at the ineffectuality of the proposed offerings, which even includes conditionals that "If thou dost give me wealth; I'll restore / All back unto thee" (19-20). It is not until the end that the speaker rejects the various offerings for an appealing solution:

Nay, I will reade thy book, and never move

Till I have found therein thy love;

Thy art of love, which I'le turn back on thee,

O my deare Saviour, Victorie! (45-49) ${ }^{60}$

If this poem questions conventions of imitatio Christi, the imitation comes not from recreating Christ's passion - which, per the final couplet, “Then for thy passion - I will do for that . . I know not what" (49-50), is an ineffable act - but trying to mirror Christ's love back in a reciprocal relationship, which the speaker cannot do on his own. ${ }^{61}$ Indeed, the closing of the poem manifests the poor workmanship of the preceding poems. Herbert's devotional act, the basis for the Protestant interpretations begins with reading the Bible and gestating on it until it is understood. These internal actions become the empowering actions that inform thanksgiving. The ritualistic sacrifices, which occupy 
most of the preceding couplets, lack efficacy when done without Christ or the mediating presence of a priest, who is subsequently empowered through Christ's sacrifice. In terms of the sequence, though the speaker desires a union, it does not occur yet. While reading the Bible gives the reader some agency, it is not until "Easter" - Christ's resurrection from his sacrifice - that, poetically, the speaker's music joins is able to consort with divine harmony.

If "The Thanksgiving" rejects ritual and Catholic devotion, as some scholars purport, the subsequent poem, "The Reprisall" (titled "The Second Thanksgiving" in the Williams manuscript) continues that line of questioning but suggests that reading alone is not enough for man to reciprocate love to Christ. While most scholars focus on the militaristic metaphors, I want to address two potentially residual Catholic elements - the meter's shape and the role of confession. Patrick observes that the shape of the stanzas, with lines of 8-10-10-8 syllables, is cruciform. ${ }^{62}$ As a metrical response to the "The Thanksgiving," with 10-8 couplets, this poem appears to consist in two stacked two elegiac couplets, with the first inverted. The tetrameters, without the longer median lines, thematically frame the poem by showing the speaker's insufficiency:

I have consider'd it, and finde ...

My sinnes deserve the condemnation.

O make me innocent, that I . . .

For by thy death I die for thee.

Ah! was it not enough that thou...

But in all vict'ries overthrow me?

Yet by confession will I [over]come ...

The man, who once against thee fought. $(1,4-5,8-9,12-13,16)$

However, this is not the poem that Herbert wrote. Although there is a hint of a conversation or apostrophe to Christ, the pentameters juxtapose man's sinfulness with Christ's "eternall glorie" (10). As in "The Thanksgiving," the relationship cannot be 
made reciprocal. This is made apparent in the first stanza: "There is no dealing with thy mighty passion" (2). Unlike Milton, who would make a similar pronouncement in abandoning his passion poem, this speaker finds poetic resolution. Answering both the second line and final couplet of "The Thanksgiving," the speaker stops trying to compete with Christ's griefs and glories:

Yet by confession will I come

Into the conquest. Though I can do nought

Against thee, in thee I will overcome

The man, who once against thee fought. (13-16)

Wilcox annotates confession as the "admission of sin, specifically here the failure to win the 'game' of rivalry with Christ." 63 Instead of attempting a losing rivalry by falling short of imitating Christ's actions, the speaker confesses his shortcomings in order to overcome the vanity or profanation of acting, on his own volition, in the place of Christ. In terms of the poem itself, the conclusion stems from self-abnegation made possible "in" Christ, a fairly typical Christological view. The poem does not comment on the role of confession. However, sequentially, this poem sets up "The Agonie," the etymology of which draws on the Greek agon "a struggle, contest, or trial" to continue the fight between sin and glory, replaced by Sinne and Love. ${ }^{64}$ The latter poem hints at the Eucharist, and thus this poem’s confession functions like liturgical, pre-communion confession.

"The Agonie" returns the reader to the liturgical sense of the early, Holy Weekinspired poems and invites the reader to partake in the Eucharist in order to know divine Love. The second stanza, inviting those "Who would know Sinne" to come to Mount Olivet to see Christ with his hair, skin, and garments "bloudie" with sweat (images like those in "The Sacrifice"), begins the Eucharistic comparisons through Christ's tribulation. The dominant allusion is that of the "presse," recalling the winepress of Isaiah 
63:1-3, the Epistle for the Monday before Easter (7-11). ${ }^{65}$ While Christ's praying in Gethsemane poetically epitomizes the struggle with sin, the victory is glossed overperhaps because in the liturgical year, the reader has only arrived at Maundy Thursday. The last stanza addresses Love and evokes the Eucharist:

Who knows not Love, let him assay And taste that juice, which on the crosse a pike Did set again abroach; then let him say

If ever he did taste the like. Love is that liquor sweet and most divine, Which my God feels as bloud; but I, as wine. (13-18)

While the second stanza addresses the struggle, the third stanza skips over the victory and moves straight into the after-effects, the elements of communion which allow the sinner to partake in Christ's own victory. To the "The Reprisall's" confession is "The Agonie's" absolution, the Love present through Christ's Eucharistic sacrifice. The sacramental importance manifests itself through the tasting of Christ's blood. Though "on the crosse a pike / Did set again abroach" alludes to the water and blood spurting from Christ's wound, the sacramental focus here is purely Eucharistic rather than baptismal. Ever the irenic, Herbert skirts around issues of Real Presence and transubstantiation in the last line by focusing on how the elements feel rather than how Love transforms the liquor. Sequentially, this poem inches us closer to Easter, but Herbert places four more poems before that culmination.

The only one of those four poems that has direct ties to the liturgical year is "Good Friday," which, in The Temple, combines what originally were two separate poems. Scholars have identified in Herbert's poem a distinctly Protestant meditation, despite the first four cross-shaped stanzas of $4,8,8$, and 4 syllables. ${ }^{66}$ The cross-like stanzas reflect several of the meditational themes of earlier poems (including the three 
other poems between "Easter" and "The Agonie"), with the first three poems asking questions about grief and sin. Take for instance the first stanza:

O my chief good, How shall I measure out thy bloud?

How shall I count what thee befell, And each grief tell? (1-4)

Like earlier poems, this apostrophizes Christ's "chief good," distinguished from the speaker's sacrifices. The poem, much like "The Thanksgiving," seeks to make a ledger of doling out blood and grief. The shift in the fourth stanza drops the comparison and shows the speaker meditating on his own individual sins. The poem makes a comparison to "thy distresse" that can "be my sunne" (15-16), a foreshadowing of the Easter poems that balance individual sins with appropriate sorrow. The final three stanzas, four tetrameters, offers a shift to the Lord again writing in blood on the heart. The speaker asks the Lord to find write in the heart so that sin does not take refuge in the heart and "blot or burn" all of Christ's writings (32). While the poem is not explicitly sacramental, the second stanza of the latter half evokes incarnational theology:

That when sinne spies so many foes, Thy whips, thy nails, thy wounds, thy woes, All come to lodge there, sinne may say, No room for me, and flie away. (25-29)

In context, these lines appear after "bloud is fittest ... to write / thy sorrows in ... My heart" (21-23). The speaker wants to write Christ's sorrows and afflictions on his heart as the debit to the credit of sin. No room for me recalls the nativity, where the innkeeper (here sin) refuses Mary and Joseph a place to lodge. ${ }^{67}$ While Good Friday is perhaps the ultimate symbol of mankind rejecting Christ, Herbert's continual linking of the Lord writing on mankind's heart with Love makes the image of the forthcoming resurrection 
hard to ignore. Incarnational theology emphasizes that Christ was born so that he could die, a cycle commemorated through sacramental participation. ${ }^{68}$ Given the importance of consuming Christ's blood for the redemption of the Christian, references to the Eucharist are muted, referenced explicitly only in "The Agonie." Instead, the devotional mood is somber, meditational, and reflective, the necessary preparative for the Eucharist and full liturgical participation. The fullest extent of such participation comes forth in celebration. With the sequence advancing to "Easter" and "Easter Wings," the devotional mood of The Temple similarly moves from solemn inner reflection to festive outward celebrations of hymn and song.

\section{Initial Culminations? A Superficial Easter and a Sacramental Sequence}

With all the preceding emotional build up and hints of the Eucharist, one might expect Herbert's two Easter poems to expound on themes of Christian salvation. But "Easter" and "Easter-Wings" do not satisfy that expectation, focusing instead on the celebratory occasion of the holy day and its expression in music through singing, larks, and playing the lute. "Easter" is stunningly superficial in the focus on outward observance and song, though it establishes motifs that later poems treat with more theological depth. While "Easter-Wings" more explicitly connects the sinner, or the singer, with the risen Christ, neither poem expounds on the long-term side effects of joining with Christ's victory for the mortal Christian. The theological importance of Easter and what it represents instead comes in the subsequent sacramental sequence, beginning with "H. Baptisme” (I) and ending with "The H. Communion," with 
meditational and confessional poem in between and followed by "Antiphon" (I), a coda to the Easter celebrations.

While the Easter poems are not a polemically laden Laudian battle cry for festival day observance, they do express a certain joy apropos to the occasion not seen heretofore in The Temple, which makes sense as Easter culminates the Lenten season. Though much of the polemical concern over English celebrations of Lent had to do with observing superstitious and popish fasts, there was nevertheless a concern for how Christians practiced religion in Lent. ${ }^{69}$ In his reading of "Easter," Hodgkins cites a prayer from Cosin's Private Devotions to differentiate the affective moods of Lent and Easter: "about the Time of His Passion we should have a sympathie, a com-passion and a fellow-feeling with him ... and that the solemn Joy of our Redemption should be put off till EASTER Day, the day of his Resurrection."70 Perhaps ignoring the context of this prayer - that Cosin identifies "His Passion" specifically as Good Friday and includes this prayer in devotions for "The Week before Easter" - Hodgkins suggests that, for Cosin, all of Lent should be a joyless occasion whereas for Herbert Easter joy fills every day of the Christian life. Such a reading de-emphasizes the liturgical sequence and meditational mood that leads to Herbert's own Easter poems, especially since the preceding poems are relatively joyless. Contrary to Hodgkin's argument that the absence of explicit references to Easter in these poems means that Easter is every day, which in my opinion is better suited to the poem "Sunday," I maintain Herbert's "Easter" elevates its festive status and distinguishes it from other Sundays and days in general. ${ }^{71}$ The last stanza best exemplifies this argument:

Can there be any day but this, Though many sunnes to shine endeavour? 
We count three hundred, but we misse:

There is but one, and that one ever. (my emphasis, 27-30)

The emphases here are on the one and the sun. In the previous stanza, the sun allusively refers to Christ ("The Sunne arising ... he give light" 23-24). Here, the many sunnes refers both to those, like the speaker of "The Thanksgiving," who err in competing with Christ's light (recalling the "they presume" who "should offer to contest / With thy arising" in lines 25-26) and to days of the year as "any day" and "we count three hundred" suggest. Whereas Hodgins takes "that one ever" to mean that the Easter light expands to each other day, I take it to mean that this day is the one day that matters. For the speaker of "Easter," there is one Christ and one day that he rises - a point made clear in the first part of the "double poem" (a poem that The Temple prints as one poem where the manuscripts had two identically titled poems). While a metrical shift occurs between the third and fourth stanzas, the "celebrat[ion of] this most high day" remains constant in both parts (12).

Part of the festivity of "Easter" stems from its grounding in liturgical and biblical echoes, which informs much of the songs and hymns within the poem and lessens the superficial veneer. The first half of "Easter" recalls "The Altar" (with its allusions to Psalm 51), but, instead of lamenting a broken heart and asking Christ's sacrifice to replace his own, the speaker redirects the imperative to his heart:

Rise heart; thy Lord is risen. Sing his praise ... . ... that thou likewise With him mayst rise: ...

$O$ let thy blessed Spirit bear a part, And make up our defects with his sweet art. (1, 3-4, 17-18) Instead of replacement, the heart and song seek union. The second half of the poem shows that this union is possible because Christ - using Herbert's verb from the previous 
poems - prevented him and provided his own "sweets" (19-22). The BCP's collects for Easter Day and Easter Monday, celebrating Christ's overcoming of death that "opened unto us gate of everlasting life," highlight "thy special grace preventing us" to promote "our minds" to "good desires" and "good effect, through Jesus Christ."72 While Herbert does not reference prevenient grace explicitly, the speaker plays with the concept with the speaker raising his art for the day's celebration. The references to "Rise heart; my Lord is risen. Sing his praise" and "Awake, my lute, and struggle for thy part" $(1,7)$ connect the poem to two liturgical sources, the sursum corda of the Holy Communion service and Psalm 57:8-11, a Proper Psalm for Easter Day Matins. ${ }^{73}$ Tuve takes the lute imagery to represent "man as God's music, his sinews or heart-strings stretched like those of an instrument," playing on a conceit of the crucified Christ as a lyre. To her, the entire poem functions as a hymn, equating the "semi-liturgical lyrical" poem with the Salve festa dies processional hymn that centers on the festival day itself. ${ }^{74}$ Much can be said of this conceit. In the second stanza, initially addressed to the lute, the speaker says that "The crosse taught all wood to resound his name ... His stretched sinews taught all strings, what key / Is best to celebrate this most high day" $(9,11-12)$. Wilcox annotates crosse to include the bridge of a musical instrument; line 9 is also the middle line of the stanza, which in shape resembles a harp or cithara (a harp is apostrophized in Psalm 57) or, less convincingly, an oblong heart. ${ }^{75}$ The image of stretching Christ's sinews over the lute reflects the first stanza, where the heart sings the praises of the risen Lord "Who takes thee by the hand, that thou likewise / With him mayst rise" (3-4). This union enriches the heart, otherwise "calcined . . to dust," with "gold" and becomes "more just" (5-6). This slight salvific reference to justification thematically echoes the Easter Tuesday collect of 
recognizing the "Sonne to die for our sinnes, and to rise againe for our justification." 76 The third stanza reiterates this union, asking Christ to be the third part of the "Consort" between "heart and lute" because it is with "thy blessed Spirit" that can "make up our defects with his sweet art" $(13,17-18)$. The second half of the poem plays with a similar conceit, where the speaker "got me flowers to straw thy way" only to be prevented because "thou wast up by break of day, / And brought'st thy sweets along with thee" (19, 21-22). While this is also an echo of the women coming to Christ's empty tomb in Mark 16, it speaks to uniqueness of Christ's role in Christianity and how little the Christian can do. ${ }^{77}$ Unlike the poems before this, the speaker can join with Christ instead of competing against him - though the speaker will continue to question the value of his own art and contributions throughout The Temple. Despite Easter being one of three liturgical occasions when communion was typically offered, "Easter" contains no explicitly Eucharistic elements, with the poem instead privileging the laudatory acts of song to accompany the union with Christ. ${ }^{78}$

"Easter Wings" reiterates the central verbs of "combine" and "rise" in a slightly more meditational context that serves to internalize the celebrations of the preceding "Easter," even though the doctrinal or Eucharistic significance of the holy day remains absent. In each set of "wings," the shape of the poem mirrors the thematic mood, with human frailty diminishing the first half of the stanza and Christ's victory expanding the second half. ${ }^{79}$ As the text contracts and expands as the reader progresses through the lines, the act of reading replicates the beating of a wing around the central point. This motion both looks back and forward - back on the meditations on sin in the Holy Week poems and forward to the myriad poems of The Church that range between affliction and 
joy. ${ }^{80}$ The crux of each stanza is the joining "With thee" in the middle $(6,16)$, to which the speaker asks to "let me rise / As larks, harmoniously, / And sing this day thy victories" (7-9) and "Let me combine, / And feel this day thy victorie" (17-18). The first stanza concerns the more external action of singing. The Williams manuscript originally had sacrifice as the object of sing line 9 instead of victories, which would link the song and poem back to "The Altar" and "The Sacrifice." 81 The resolution of both stanzas, however, is internalized. Though the speaker initially sings the victories of Christ's sacrifice, the joint rising allows the speaker to resolve: "Then shall the fall further the flight in me" (10). Just as the stanza begins with wealth, shrinks in poverty, and rises in victory, the greater the fall (doubtlessly metonymic for man's fall) allows for the greater victory through rising with Christ's resurrection - though the connection is implicit, as Easter appears only in the poem's title. The second stanza reiterates this connection with an even stronger connection between Christ and speaker, the logical conclusion of line 16's "combine:" "For, if I imp my wing on thine, / Affliction shall advance the flight in me" (19-20). Though the tenor of the speaker's message seems clear, the image itself is not so clear. Wilcox notes that imp means to "engraft feathers in a wing to restore or improve its power of flight" but comments that it is "(wrongly) interpreted as the Christian resting his/her wings on Christ's" and says that it is "feathers from the triumphant Christ's 'healing' wings" that are used to "repair and 'advance the flight 'of the sin-damaged Christian'." ${ }^{82}$ The issue with this interpretation is that the grammar of the poem does not support it; it is the speaker who imps "my wing on thine" rather than Christ's onto the speaker's. Ignoring the theological belief that Christ took on the sins of everyone, Herbert's grammar is logical: the sinner's meditation looks inward, so the 
grafting of imperfect, sinful wings, would add affliction to the wings. Much of the lyrics to this point have pointed to the insufficiency of the speaker's own acts. Here, the line reiterates this, but the final line also emphasizes that Christ's sacrifice, now grafted together with the speaker's, results in a greater gain. For the speaker to imp Christ's wing would negate the sinner's affliction, for the mortal could not withstand the affliction of all sinners - just their own, and only through joining in Christ's salvific actions. This is done "harmoniously" (8), through the union of the sinner and the redeemer. Thus, in both poems, joining with Christ stands at the center, with "Easter" consisting of a primarily external manifestation of joy and "Easter Wings" being more internalized. ${ }^{83}$ While the sacraments do not feature prominently in the two Easter poems, the speaker nevertheless progresses to an internal state of reflection that suggests proper sacramental preparation, which the subsequent poems explore in more detail.

The sacramental sequence, which I limit here to the poems between " $\mathrm{H}$. Baptisme" (I) to "The H. Communion," walks the reader through a Christian's life that begins with baptism and "ends" with communion, the vehicle for Christians receive God's grace and enter into eternal life (a simplistic reduction of "The H. Communion," lines 19, 35-40). ${ }^{84}$ The sequence plays on multiple inner - outer dichotomies, reflecting the definition of a sacrament as an external sign of inward grace. While the " $\mathrm{H}$. Baptisme" poems, for instance, have themes of grace and redemption, the first uses watery images while the second is more internal, focused on the soul's health rather than the act of baptism itself. ${ }^{85}$ The placement of baptism poems after Easter reflects Herbert's liturgical mindfulness, as baptisms often took place on that occasion. ${ }^{86}$ Theologically, the sacraments "shew, what Christ hath done" ("Faith" 36), so in aligning with Lake's 
description of Laudian style, Herbert's sacramentalism highlights Christ's role as redeemer (e.g., "H. Baptisme" [I] 6, 10) and the importance of sacramental participation.$^{87}$ The latter part of this sequence, particularly "Affliction" (I) and "The H. Communion," also engages with church externals (fine furniture and arrays), which scholars have used to complicate Herbert's relationship to Laudianism, often due to seeing Laudianism as being wholly focused on the external processes, rather than the inward grace sacraments bestow.

This inwardness begins with meditation. In "H. Baptisme" (I) the reader comes across the speaker looking backward on his sins and onto Christ's redemption. In rhyme, the poem resembles an English sonnet, but the punctuation, with full stops at lines 2, 6, 9, 11 , and 14 , belies conventional integrity ${ }^{88}$ The poem begins with a focus on metaphorical sight:

When I view my sinnes, mine eyes remove More backward still, and to that water flie, Which is above the heav'ns, whose spring and rent Is in my deare Redeemers pierced side. (3-6)

Sight transcends the present moment, with the sins leading the speaker to look "More backward still" onto Christ's crucifixion. The water and blood of Christ's piercing symbolically represent the two signs of the Protestant sacraments, which the poem then apostrophizes in "O blessed streams" and declares that "either ye do prevent / And stop our sinnes from growing ... Or else give tears to drown them" (7-10). Herbert's punning use of prevent inverts the backward temporality of the sight that begins the poem: Christ's priestly, sacramental sacrifice happened in the past and before us, but that sacrifice effectively prevents sin's damnation on future generations of Christians (provided proper sacramental observance and pious behavior occur). Christ's "first 
acquaintance" with the speaker through baptism serves as "Redemption" for "all my time" that "discredit[s] all" sins, in the past or the future $(14,11,14)$. For Herbert, baptism reflects the remission of sins and has a timelessness that affects the Christian all the days of their life (a view that aligns with Hodgkins's every-day-is-Easter argument).

On the other hand, "H. Baptisme" (II) only looks only backward, and while there is a focus on the grace and health of a child, the shape of the poem suggests a certain materiality. As mentioned above, the "closed form" poem has been read as a "pattern of grace," with the stanzas evoking some kind of heart-like or baptismal shell shape. ${ }^{89}$ The first stanza reveals the other scriptural referent (Matthew 7:14a, KJV: "Because straight is the gate, and narrow is the way, which leadeth unto life") and begins the emphasis on infancy and childhood:

Since, Lord, to thee A narrow way and little gate Is all the passage, on my infancie Thou didst lay hold, and antedate

My faith in me. (1-5)

The tenuous support for reading the stanzas as a baptismal shell rests on "passage," where the Lord (the "thee" to whom the speaker heads) is the object of the pilgrimage. If Mark 10 suggests reaching the Lord through the kingdom of heaven as children, then life itself becomes a pilgrimage. The problem with this reading is the poem's backward focus. Where baptism in the first poem forgives sin, in this stanza it represents faith, which, in conjunction with the narrow way, shows the speaker's entrance to the Lord. The following stanzas represent a longing to maintain childlike innocence: “O let me still ... and me a childe" (6-7). The third and final stanza connects this preservation not to the flesh which "get[s] on" and "is but a blister" but to the soul, which "bid nothing" to be 
preserved (12-14). However, in reading this as a sequence, the subsequent poems move forward in time towards the Eucharist and further receiving of grace. Because the speaker cannot maintain childhood innocence due to sin, the subsequent poems on "Nature," "Sinne" (I), and "Affliction" (I), lead the speaker to "Repentance" before resting in "Faith" and "Prayer" (I) before "H. Communion."

Of the intermediary poems, "Affliction" (I) deserves the most attention, as its initial concern on taking pleasure out of "furniture so fine" (7) speaks to concerns of Laudianism. Wilcox conflates two of Ilona Bell's arguments to take the poem "as a sign of H[erbert]'s growing out of Laudian ways" prior to his 1626 ordination, though the argument rests on a narrow view of Laudianism as external. ${ }^{90}$ While the poem has a linear motion to it, lending to its autobiographical reading, it also has a circular motion that complicates a straight biographical reading, beginning and ending with an attention to service. ${ }^{91}$ The poem opens "When first thou didst entice to thee my heart, / I thought the service brave" (1-2), providing "So many joys" (3) that, in addition to the speaker's natural delights, are "Augmented with thy gracious benefits" (6). This pleasure comes from the service of a "King" (13). Wilcox notes brave invites a reading of "splendid" as if talking about a "handsome ceremony" and suggests a liturgical pun on a church service. ${ }^{92}$ While the second stanza supports this potential reading and, when Laudian is delimited to an exclusive emphasis on outward things, ${ }^{93}$ refines it to physical accoutrements, it is important to note that the augmentation in line six has a connotation of joining together in order to make larger. The service inspires joys, as do the speaker's "stock of natural delights" (5), but they join with the King's gracious benefits" to create even more joy. If the King represents God, then reading this in sequence suggests that the 
splendid service magnifies the sacramental grace bestowed onto the heart. ${ }^{94}$ Nevertheless, the second stanza focuses on the splendid array - presumably of or in the church:

I looked on thy furniture so fine,

And made it fine to me:

Thy glorious household-stuffe did me entwine, And 'tice me unto thee.

Such starres I counted mine: and both heav'n and earth

Payd me my wages in a world of mirth. (7-12)

Continuing line six's augmentation, both earthly and heavenly things delight the speaker. The emphasis on early delights and furniture foreshadows at least two other poems in The Church: the "rich furniture, or fine aray" in "The H. Communion" that no longer conveys God to the speaker (line 1) and the prelapsarian paradise of "Affliction" (V). The latter poem uses the shift from fine pleasures to affliction to indict Adam's Original Sin, rather than misuse of church furniture. ${ }^{95}$ With the former, and with "Affliction" (I)'s onset grief, it is easy to see this as a rejection of external furnishings of the temple or church. The poem offers no meditative or inward resolution or compromise that is present in other apparent rejections of outward ceremony elsewhere in The Temple. ${ }^{96}$ After looking on the fine furniture, the speaker talks of other pleasures and sweetnesses but laments that "My flesh began unto my soul in pain" with "Sicknesses" (25-26). Not even reading (39: "Thou didst betray me to lingring book;" 56-7: "None of my books will show. / I read, and sigh, and wish I were a tree") provides solutions for the afflictions of the speaker. While there are autobiographical overtones to this sickness and the academic gowns (40, 45), the poem offers no clear resolution if the splendid service itself is forgone.

The final stanza sounds a paradoxical note, and, depending on how the conclusion is read, it may change the understanding of the entire poem. The last stanza reads:

Yet, though thou troublest me, I must be meek; 
In weaknesse must be stout.

Well, I will change the service, and go seek

Some other master out.

Ah my deare God! though I am clean forgot,

Let me not love thee, if I love thee not. (61-66)

This stanza contains at least two biblical echoes - the Sermon on the Mount's Beatitudes and prescription against serving the two masters of God and Mammon (Matthew 5:5 and 6:24) and 1 Corinthians 12:9-10 (KJV: "My grace is sufficient for thee: for my strength is made perfect in weakness ... When I am weak, then am I strong"). The challenge to these allusions is that the text of the poem never makes it clear that speaker received or maintained grace (line 48's "I could not ... persevere). The abrupt apostrophe to God seems to interrupt the speaker's changing or looking for other masters - a logical reading, given that subjection to God should be sufficient. While it may be tempting to go back and read line 13 's "King" as a king of earthly pleasure (so that the external service and delight was not Godly and that the remembering God at the end is a Christian turn to God), the wages paid in line 12 are from "both heav'n and earth" and the "milk and sweetnesses" of line 19 (which Wilcox reads as stemming from baptism) recalls God's provision in Exodus 3:8, showing that the "thou" of the entire poem has been the Christian God. ${ }^{97}$ Up to this point, I have left out the interplay between the speaker's firstperson and the direct address to God. In the final couplet before the shift to the present "Now," the speaker admits God's power: "Thus doth thy power crosse-bias me, not making / Thine own gift good, yet me from my wayes taking" (53-4). Wilcox glosses "crosse-bias" to mean a shift in direction, while also noting that the bias shifts toward the cross, offering redemption. ${ }^{98}$ But the poem resists redemption. Even after this declaration, the speaker still admits problems with his own actions (he reads, sighs, and wishes in line 
57). It seems that all of the insufficiency of the speaker stems from his overreliance on what he can do - the first-person pronoun (I, me, my) appears 63 times, compared to 18 instances of the second person (thou, thee, thy). As such, there are two verbs the speaker can do: he can serve, and, as the last line puzzles, he can love. The interjection in the last stanza serves for the speaker not to seek another master, but to redirect his love so that he can love God properly, so that he can in fact, enjoy God's goodness. The interjection of "Ah my deare God!" seems to dismiss the seeking another master. In saying "I am clean forgot," the speaker seems to reject the self-obsession that dominates the poem and allows him to return to the original joy that opened the poem, where the brave service when done properly - augments (rather than replaces) the "gracious benefits" of the master. Affliction, then, serves as the reminder for the speaker not to be prideful, but to embrace the meekness and weakness to be a better servant. Such a view is not antiLaudian. As Buckeridge asserted, gesture (or, writ large, ceremonial grandeur) means nothing without the heart's presence. ${ }^{99}$

To read "Affliction" (I) in sequence suggests that it is but a part of the reflection leading towards forgiveness through the taking of communion. "Affliction" (I) follows "Sinne" and precedes "Repentance," a poem with strong echoes of the Penitential Psalms. In the middle of the poem, the speaker cries out: "Cut me not off for my most foul transgression: / I do confesse / My foolishnesse" (15-17). ${ }^{100}$ That his great sin (lines 1-2) is foolishness could cast "Affliction" as a poem admitting his fault as being foolish and continues Herbert's sequential trend of using keywords as transitions between adjacent poems. The penitent speaker asks God to "sweeten at length this bitter bowl" (19), which reiterates that God can turn sourness sweet and holy sweetness cannot come from man. 
Once penitent, the sequence moves to "Faith." The poem has a few important thematic echoes - including the declaration that "Faith makes me any thing" before an "Easter" juxtaposition that "sinne placeth me in Adams fall, / Faith sets me higher in his glorie" $(17,19-20)$. "Faith" also looks ahead to "Love" (III) in terms of being a guest at a heavenly feast. The second stanza of "Faith" reads:

Hungrie I was, and had no meat:

I did conceit a most delicious feast; I had it straight, and did as truly eat,

As ever did a welcome guest. (5-8)

Like "Love" (III), the central verb of this stanza is eat. Faith allows the speaker to be a welcome guest as it allows the sinner to participate in the Eucharist. This, however, happens only after prayer. The opening phrase of "Prayer" (I) suggests the communal, feast-like element to prayer: "Prayer The Churches banquet" (1). The sacramental element to prayer appears with the later references to "Christ-side-piercing spear" (6) and the "Exalted Manna" (10), which has a Eucharistic typology to Exodus $16 .{ }^{101}$ With all of this Eucharistic anticipation, "The H. Communion" becomes the tonal culmination of the sacramental sequence.

Because the poems after "The H. Communion" turn their attention to the poetic craft, the poem itself is an important fulcrum within The Church in that the implicit narrative of The Temple changes course once the communicant has consumed the elements of grace. With the focus on grace, humility, and nourishment, this poem remedies the pains from the afflictions brought on by sin, as expressed in the preceding poems. Critics disagree over the "Anglicanism" in "The H. Communion" but agree that The Temple's version is less doctrinally charged than the poem of the same title in the Williams MS. Like "Easter," "The H. Communion" is a double poem, with a metrical and 
tonal shift occurring between the fourth and fifth stanzas. Critics comment that the first part stresses "meaning" while the second stresses "feeling" or "personal emotion."102 As with the "H. Baptisme" poems, I take this to be a sacramental division in line with Laudian thought, with the first four stanzas, with an ostensible focus on the outward elements, making way for the prayerful, inward reflection in the second half of the poem.

The opening of the poem is often read as a dismissal of popish ceremony, which it might be, but that reading overemphasizes the first stanza, as the poem is more concerned with what the elements of communion do to body and soul. The first two stanzas read:

Not in rich furniture, or fine aray,

Nor in a wedge of gold,

Thou, who from me wast sold,

To me dost now thy self convey;

For so thou should'st without me still have been,

Leaving within me sinne:

But by the way of nourishment and strength

Thou creep'st into my breast;

Making thy way my rest,

And thy small quantities my length;

Which spread their forces every part,

Meeting sinnes force and art. (1-12)

Wilcox reads the opening couplet as a "rejection of the elaborate [sic?] ceremonial associated with the Catholic Mass,” citing Cranmer's “Of Ceremonies” promoting "decent order and godly discipline" in the services of British liturgy, but the poem has no other reference to ceremony or service. ${ }^{103}$ Contrarily, Whalen writes that "even if many of his contemporaries would have recognized these as the trappings of the Roman Mass, Herbert does not dismiss the use of such external finery per se. His objection, rather, pertains specifically to the idea that externals might themselves effectually conjure or somehow contain their divine referents." 104 To Herbert, this instance of communion is deeply personal and individualized rather than communal - a distinction that separates 
this poem from the likes of "Prayer" (I) and "The Invitation" but predicts the postmortem banquet in "Love" (III) ${ }^{105}$ The temporal rejection of rich furniture echoes and predicts the thoughts expressed in "Affliction" (I) and "Sion." The latter poem, however, emphasizes the offerings of man. Here, the speaker emphasizes the union - made possible through Easter and the resurrection - of Christ and sinner. It is not through an ornate cup that the grace of God enters in, but through the bread and wine. The nourishment is physical, with "sinnes force and art" coming to a head within the believer's body. The "small quantities" that "creep'st" stand juxtaposed to the "fine aray" that the speaker initially rejects. The subsequent two stanzas refine this concept even more.

While the first two stanzas show the growth of Christ within the flesh of the speaker, the second two change gears to show that the material elements, whether ornate or humbly creeping, are not the full benefit of the Eucharist; physical elements benefit the physical body (as in lines 15-16, below). The full power of the Eucharist benefits the soul. The third and fourth stanzas read:

Yet can these not get over to my soul,

Leaping the wall that parts

Our souls and fleshly hearts

But as th' outworks, they may control

My rebel-flesh, and carrying thy name, Affright both sinne and shame.

Onely thy grace, which with these elements comes, Knoweth the ready way, And hath the privie key, Op'ning the souls most subtile rooms While those to spirits refin' $d$, at doore attend Dispatches from their friend. (13-24)

The Calvinist reading presents itself with these lines: from the rejection of the rich furniture, the speaker takes pride in the grace provided by communion to overcome the 
sinful flesh to open the door to refining the spirit. Herbert is irenic enough to avoid controversy by showing grace to accompany these elements without insisting how or in what manner the elements are transmuted. For Herbert, like Hooker, grace is the "essential form" of the Eucharist. ${ }^{106}$ Herbert does seem to suggest that the physical elements correspond to fleshly sin, but the health of the soul and fleshly hearts (cf. line 29 "Before that sinne turn'd flesh to stone") must depend on the grace that comes with Eucharistic participation. With grace having opened the doors to the soul, the poem shifts gears to focusing on the inward state of the body and soul.

As the second half of the poem reveals, the greatest effect of the Eucharist is the soul's restoration to paradise, undoing the effects of Original Sin. The fifth and eighth stanzas relate the latter half of the poem to the first:

Give me my captive soul, or take My bodie also thither. Another lift like this will make Them both to be together. . Thou hast restor'd to us this ease By this thy heav'nly bloud; Which I can go to, when I please, And leave th' earth to their food. (29-32, 37-40)

The interceding stanzas look back on a time before sin, when Adam might “to heav'n from Paradise go, / As from one room t'another" unrestrained from the knowledge and ability to sin (35-6). While "another lift" suggests the second coming and resurrection of all, the preceding lines show that it is through communion that the soul and body will eventually be restored to a sinless state, and be rewarded with eternal, Christian bliss. Where the first half of the poem emphasized the elements of the Eucharist allowing the body to grow with Christ's influence to expel sin, the back half shows the effects on the 
soul, when purged of "rebel-flesh" and its sin and shame. Here, in Christian salvation through the sacrament, is the culmination of Easter.

The coda to the sacramental sequence is "Antiphon" (I), which demonstrates the fluidity of the various sequences within The Church. The poem, like the initial two Easter poems, is a Psalm-like hymn of praise and thanksgiving. It is also a transitionary poem that predicts the quasi-ars poeticae nature of the subsequent "Love" sonnets and "Jordan" (I). To overread influence of the $B C P$ as organizational metaphor, in this conception, "Antiphon" (I) acts as a poetic rendering of the Gloria hymn in the Communion service that precedes the benediction and the post-offering collects. ${ }^{107}$ Almost every line of the poem has a reference to the psalms or liturgical song, including the Venite and the Te Deum. ${ }^{108}$ One of those Psalm references is the repeated "My God and King" chorus, which appears three times in the poem and at the end of "Jordan" (I). The phrase has at least four appearances in the Psalms $(5: 2,68: 24,84: 3,140: 1)$ and is used in the Sidney translation of Psalm 59. ${ }^{109}$ The two verses of the antiphon raise high the praises of God so that they can grow on earth (3-6) so that "The church with psalms must shout" praises, provided that "the heart / Must bear the longest part" $(9,11-12)$. Psalm-singing is a communal activity, but it is still the individual who must be earnest in the worship while singing "My God and King." The question of identity, who sings, and the value of human art is brought up in the subsequent poems. The notion of the church and apparent conclusion of the liturgical year appears in the "Church sequence," which is the last of the drawn-out sequences in The Temple (aside from the apocalyptic conclusion) and follows a brief artistic interlude. 
IV. Enflaming the Broken Heart: the Artistic Interlude and Poetry Sequence

The next sequence of poems, roughly "Love I" to "Jordan" (I), concerns itself with artistic invention. ${ }^{110}$ Ironically, in a dissertation structured around genre, I am not too concerned with what Herbert has to say about poetry itself, aside from where ornate expression and decorous language intersect with Laudian themes of ceremony and external/internal manifestation. ${ }^{111}$ These poems concern themselves with beauty, and my concern for this sequence is less about the sequence itself than with the establishment of motifs that will resonate with Herbert's poems on the physical elements of temples and churches in later sequences. One of these motifs begins in "Love I," in which "Immortall Love" is "Sprung from that beautie which can never fade" (1-2). Herbert's poetic concern is whether mortal invention can imitate or replicate that type of eternal beauty. As we have seen with imitating Christ's grief, all human replication falls short, but the poet should still try to write of divine love as an act of praise.

"Love II" dramatizes the relationship between divine inspiration and human craftsmanship in a ritualistic sacrifice. In this poem "Immortall Love" becomes "Immortall Heat," the basis of a recursive cycle of sending fire (an image reminiscent of Pentecost, but reader is six poems away from "Whitsunday"). The poet's apostrophe asks Heat to "let thy greater flame / Attract the lesser to it: let those fires ... kindle in our hearts such true desires, / As may consume our lusts" (1-2, 4-5). Heat's greater flame inspires the human artists through purifying the heart. In turn, the artists can make their own sacrifice, beginning the cycle again: "Then shall our hearts pant thee; then shall our brain / All her invention on thine Altar lay, / And there in hymnes send back thy fire again" (6-8). In this conceptualization, art becomes a sacrifice offered as praise. The third 
quatrain of the sonnet turns to the eyes, which now "shall see thee, which before saw lust" (9). Throughout The Temple, dust is attached to mortality (especially in "Churchmonuments"), and the overall image here of "blinde" eyes (10) recalls the polluting effect of lust in "The Church-porch" (6-12). God's heat in this poem represents redemption through restoration - as we just saw in "The H. Communion." 112 The closing couplet makes this clear through scriptural allusion: "All knees shall bow to thee; all wits shall rise, / And praise him who did make and mend our eies" (13-14). The allusion is Philippians 2:10. Kneeling, again, serves as a sign of humility to a greater power. ${ }^{113}$ The humility present here is through recognizing the "lesser flames" of mortal art, a theme found in "Jordan" (I).

The scholarly debate around "Jordan" (I) tends to focus on the question "Is there in truth no beautie?" (2) and its apparent answer in "Who plainly say, My God, My King" (15). ${ }^{114}$ My interest in the poem centers on its foundational motifs of beauty. In "Jordan" (I), Herbert shifts the Platonic debate on whether poetry can capture truth into the realm of religious truth: "May no lines passe, except they do their dutie / Not to a true, but painted chair?" (4-5). In its immediate context, the paint of the chair reflects Plato's deceptive cosmetics, but in other poems the chair has ecclesiastical associations. In "The Temper" (II), the chair is the chair of grace; "Church-rents and schismes" plants the "Brave rose" of the church in a chair (1); "The British Church" lambasts the Roman church for its painted shrines that rub off on her face $(11,16)$. Paint, then, has few redeeming qualities in the whole of The Temple, though "Sinne" (II) offers one potential reprieve: "We paint the devil foul, / yet he hath some good in him, all agree" (2). Combining the sentiment of "Sinne" (II) with the question here, there seems to be 
devotional value and truth in beautiful objects - a theme that may stem from Hooker and is explored more in-depth in the following sequence of liturgy and church objects. ${ }^{115}$ The speaker's question can, then, be seen in light with an Andrewesian notion of the beauty of holiness. As established in Chapter One, this beauty of holiness, not bound exclusively to church accoutrements, uses external beauty as a reflection of holiness to spur inner reverence. The poem's last two lines - "Nor let them punish me with losse of ryme, / Who plainly say, My God, My King” (14-15) - appeal to those who prefer plain speech and simple devotions not to condemn the poet for his inventions. The irony is that the plain speech stems from the Psalms and served as the refrain of "Antiphon" (I) - My God, My King is plain, but it is both poetry and song. The answer to the question, then, is that there is truth in beauty, but it need not always be ornate.

The last line's emphasis on plain speech has been read as a Calvinist appeal to simplicity. ${ }^{116}$ This appeal returns in other poems outside this short sequence with an explicit concern for how the poet dresses the language. The obvious companion to "Jordan" (I) is the second poem by that name, "Jordan" (II). Where the first poem seems to end with a defense of making poetry, the second praises sparse simplicity. "Jordan" (II) is a narrative, beginning with a desire for ornate imagery: "When first my lines of heav'nly joyes made mention, / Such was their lustre, they did so excel, / That I sought out quaint words, and trim invention" (1-3). The speaker puns on trim, meaning both decorous language and language lacks concision and precision. Wilcox annotates this line with a citation of Featley's Ancilla Pietatis: "do your worke holily rather then over neately; reverently, rather then trimly."117 The speaker's "plain intention" was "decking the sense" through swollen metaphors (5-6). The effect of this salesmanship (6: "As if it 
were to sell") is inadequacy: "This was not quick enough, and that was dead. / Nothing could seem too rich to the clothe the sunne" $(10-11)$. Here is the irony of clothing poetry in majestic, highly wrought language. The sunne, that symbol of Christ, represents all types of ascendant majesty, which human invention cannot capture. The ornate language is "not quick enough" and "dead." When compared to the quick flying groans of "Sion" (21) or the "easie quick accesse" of "Prayer" (II) (1), the speaker of "Jordan" (II) moves to a preference for plain utterance, even in rhyme and meter. ${ }^{118}$ Hence the conclusion of the poem: "How wide is all this long pretence! / There is in love a sweetnesse readie penn'd: / Copie out onely that, and save expense" (16-18). Herbert moves for a moderation in verse, resembling the meanness he praises in the British church. While "The British Church" connects beauty to Church of England, "The Forerunners," a much later poem in The Church, connects the beauty of poetry to the physical church. Like "Jordan" (I), it takes a biblical phrase, "Thou art still my God" (6, 9,32 ), to reflect on beautiful language to combat the pangs of "dulnesse" (5). ${ }^{119}$ After appropriating the Psalmic phrase, the poet purports that "He will be pleased with that dittie; /And if I please him, I write fine and wittie" (11-12). Here, fine means moderate. The speaker takes much effort to bid "Farewell" to "Sweet phrases, lovely metaphors" (13) that had to be washed "With my tears" so that he could bring purified writing "to Church well drest and clad: / My God must have my best" (16-19). Purification is necessary because sweet phrases corrupt: "Lovely enchanting language, sugar-cane . . . wilt thou flie? . . . Wilt thou leave the Church, and love a Stie?" $(19,20,22) .{ }^{120}$ With the earlier reference to brothels (15), sweet language has carnal associations inappropriate for devotion. The climax of the poem's concern for language occurs in the penultimate 
stanza, when the speaker admits "True beautie dwells on high: ours is a flame / But borrow'd thence to light us thither. / Beautie and beauteous words should go together (28-30). Should is the operative word: beauty need not be overwrought with "embellishment" (33) when a simple phrase suffices. With "True beautie dwells on high," Herbert returns to the notion that divine truth is ineffable, and not met in pretty words. Moreover, the association with the flame recalls both "Love" sonnets, with the neverfading beauty and the recursive heat gifted to humans that transports them to heaven. While I have jumped around in The Church in this section, it is important to ground Herbert's ideas about art, eloquence, and poetry because similar actions occur with the use of images and physical elements within the church itself, a theme explored in the subsequent sequence, where the titles of the poem invoke the liturgical church year and the external elements of the church.

\section{The Liturgical Church Sequence: "I go to Church"}

Thinking in broad sequential strokes, The Church-porch is the preparatory sequence for the reader to enter inside the church. The Church's sacrificial sequence culminates in the sacraments, forcing the reader to accept Christ's sacrifice and recognize that humanity cannot recreate the sacrifice. The "poetic interlude" applies that lesson to art. The subsequent sequence, the last of the introductory sequences before The Church turns to a wider array of devotional poems, then brings into question the role of liturgy and elements of the physical church in one's devotional life - what Hanley calls "the nature of the Church, the source of grace." ${ }^{121}$ For my purposes, this sequence has two Laudian features, the apparent emphases on the liturgy and the physical church. ${ }^{122}$ In 
what Hodgkins calls Herbert's "vanishing" technique, the text of the poems do not always reflect their titles in predictable ways, which could suggest Herbert rejects the outward forms altogether. ${ }^{123}$ I, however, maintain that while Herbert does seek to avoid controversy, he uses the outward images to spur internal thoughts and meditations, using the images as edifying aids, rather than targets of devotion themselves. This argument has similarities to Fish's model of catechistical method, wherein the architectural metaphor is internalized with the reference trying to build a Christian temple inside the reader's heart, and Whalen's "Sacramental Puritanism." 124 Fish, however, does not concern himself with Laudian-Calvinist distinctions and focuses on the didactic energies within The Temple rather than how Herbert's irenic poetry contributes to the discourse of Protestant worship. Where Hanley begins her temple sequence with "Mattens," I opt for the earlier " $\mathrm{H}$. Scriptures I" and end with "Trinitie Sunday," fourteen poems later. ${ }^{125}$

I begin with the two "The H. Scriptures" poems because the English liturgy is essentially Scripture in paraphrase. ${ }^{126}$ These poems examine the act of reading itself, with the Bible acting as God did in previous poems. Unsurprisingly, the Bible is the Protestant's salve: "let my heart / Suck ev'ry letter, and a hony gain" because "Thou [sc. "Oh Book!"] art all health, health thriving" (1-2,5). Where earlier Christ's sacrifices and Christian service provided sweetness, here the speaker is thrust into an active role where reading Scripture offers a corrective: "Ladies, look here; this is the thankfull glasse, / That mends the lookers eyes" (8-9). The couplet concludes "Thou art joyes handsell: heav'n lies flat in thee, / Subject to ev'ry mounters bended knee" (13-14). Wilcox annotates handsell as "foretaste" or "first installment," drawing on the word's definition as a gift, often one given at marriage or the start of some new occasion. ${ }^{127}$ Handsell 
suggests a sense of promise that the Bible offers to the reader and believer. While "heav'n lies flat in thee" puns with a flat book, it also contrasts the "mounters" (those who ascend) who are subjectively kneeling in reverence - presumably through praying with the Bible or through its paraphrases in the $B C P$ or other devotionals. ${ }^{128}$ "The $\mathrm{H}$. Scriptures II" contains similar themes, though it uses an extended astronomical conceit: "Starres are poore books, \& oftentimes do misse: / This book of starres lights to eternall blisse" (13-14). Like the risen Christ, the Bible's light benefits the reader in allowing them to see their redemption. In these two poems, the act of reading is relatively straightforward in its benefits. The rest of the sequence lacks that simplicity and directness.

"Whitsunday" is the first holy day poem in this sequence. In a Laudianism-aswholly-external reading, one might expect to see "Feasting all comers" (8) to be the central conceit of the poem praising the festival, but the poem concerns itself with the "glorious gifts" bestowed at the original Whitsunday to the twelve apostles (9), which the Holy Spirit no longer gifts "by the fault / Of those, who did themselves through their side wound" (19-20). As noted by Low, this poem has multiple echoes of "Easter," with its light, flight, and singing. ${ }^{129}$ The first stanza's apostrophe to the heavenly dove has echoes of "Easter-wings:"

Listen sweet Dove unto my song, And spread thy golden wings in me;

Hatching my tender heart so long, Till it get wing, and flie away with thee. (1-4)

The fourth stanza has echoes of "Easter:" "the sunne, which once did shine alone .. . beheld twelve sunnes for one / Going about the world, giving light" (13, 14-15). Drawing on those Easter themes, Herbert's Pentecost joins the Holy Spirit with human as Easter 
joined Christ and mankind. But this union is not so joyful. With the martyring of the apostles, the Spirit's "pipes of gold ... were cut" $(17,19)$ and the speaker laments that "Thou shut'st the doore ... / Scarce a good joy creeps" (21-2). This leads to the final stanza's plea:

Lord, though we change, thou art the same;

The same sweet God of love and light:

Restore this day, for thy great name,

Unto his ancient and miraculous right. (25-28)

Gottlieb, probably drawing on the "richly attended" house of line 7, sees "Restore this day" as a defense of the holy day against the puritan threat. ${ }^{130}$ Given the potential for the pun of "miraculous right" and rite, this is a plausible reading, but given the poem's lament for how sin has clouded the grandeur of the day, "Restore" could just as easily mean to cleanse the day of its anti-sabbatarian distractions. The poem does not place strong theological importance on Whitsunday - it does not, for example, like Andrewes's Whitsunday sermons, stress that the coming of the Spirit enabled all feast days and holidays. ${ }^{131}$ At the heart of the poem is a plea for the restoration of the Holy Spirit's grace to mankind. Because "The H. Communion" saw grace creeping into the speaker's breast and opening the spirit's door, the implicit resolution comes less through festive celebration and more through Eucharistic participation.

Many poems in this sequence speak to a type of regeneration between the speaker and God. While regeneration is a loaded theological term, I here mean it to be a state of improvement, towards heavenly perfection. ${ }^{132}$ In this sense, the call for restoration in "Whitsunday" wishes that the gifts of the spirit would allow contemporary men to perform the same inspired works as the apostles. The subsequent poem, "Grace," reiterates this theme in a more generalized manner with its laments that "My stock lies 
dead" and that no mortal increase will cause "my dull husbandrie [to] improve" (1-2). Thus enters the repeated refrain "O let thy graces without cease / Drop from above!" to infuse the stock of the speaker (3-4). "Praise" (I) provides another lyric variation on the theme of "mend[ing] my estate" to allow the speaker to offer better thanksgiving to God (3). Moreover, it specifically locates the action inside the church:

I go to Church; help me to wings, and I

Will thither flie;

Or, if I mount unto the skie, I will do more. (5-8)

Like "Easter-wings" and "Whitsunday," the overcoming of sin offers the soul means to ascend to heaven. As this sequence makes clear, it is not the church itself that raises the speaker, but God, through whatever means necessary - the Bible, the sacrament, or the church itself. ${ }^{133}$ The speaker of "Praise" (I) addresses his final plea, "O raise me then!," to God (17). Regeneration has an elevating effect through flying or raising, which the liturgical and church poems exemplify.

As we saw in Chapters One and Two, the liturgical Daily Offices may have been anything but daily. No one doubts that Herbert the priest conformed to the $B C P$ 's prescription to recite Morning and Evening Prayers on a daily basis - but his "Mattens" and "Even-Song" do not rely as heavily on the $B C P$ as one might assume. ${ }^{134}$ Contrary to the opening sentences of the Morning Prayer with their laments over wickedness, "Mattens" instead offers a prayer for the "morning-soul and sacrifice" (3). Certainly, liturgical echoes persist. The repeated questioning of "My God, what is a heart?" $(5,9)$ seemingly invokes Psalm 51:7's broken and contrite heart, paraphrased in the $B C P$ as "A sorowfull spirit is a sacrifice to God: despise not, O Lord, humble and contrite hearts." 135 However, unlike "The Altar" or the Penitential Psalms, "Mattens" does not highlight 
contrition. The heart becomes an object for God to "eye, and wooe" (10). The poem, rather, frames a daily call for the speaker to learn and work. It opens as if the speaker awakens: ${ }^{136}$

I cannot ope mine eyes, But thou art ready there to catch My morning-soul and sacrifice:

Then we must needs for that day make a match. (1-4)

Where the Psalm 51 versicles call upon the Lord to open the lips for praise, Herbert's "Mattens" instead alludes to other Psalms and Old Testament verses in the act of waking: Elisha's Prayer in 2 Kings 6, "Open his eyes so he may see;" Psalm 119:18, “Open Thou mine eyes, that I may behold wondrous things out of Thy law;" and Psalm 146:8 “The Lord openeth the eyes of the blind: the Lord raiseth them that are bowed down: the Lord loveth the righteous." ${ }^{137}$ The end of the poem gives credence to God raising (presumably via grace) the believers, through a sun-beam reference that recalls "Easter." The last two stanzas read:

Indeed mans whole estate Amounts (and richly) to serve thee: He did not heav'n and earth create, Yet studies them, not him by whom they be.

Teach me thy love to know; That this new light, which now I see, May both the work and workman show:

Then by a sunne-beam I will climbe to thee. (13-20)

God's workmanship in man features prominently in these last two stanzas (perhaps fulfilling line 11's "Powring upon it [the heart] all thy art"). Wilcox, citing Kinnamon, suggests that "whole estate" answers the call to "mend" the estate in "Grace" and that the workmanship invokes Psalm 95:4-6, sung in the Venite. ${ }^{138}$ Then poem then inverts some of the emphases of the liturgical office. Rather than kneeling down in praise (as in Psalm 
95:6), the speaker serves God through learning God's love, which empowers him both to see and ascend toward his Creator.

Herbert's "Even-song" functions as a completion of "Mattens." (Between the two poems lies "Sinne" [II], doubtlessly a comment on man's daily plight). Thematically, the poem draws heavily on the second and third collects that conclude the Evening Prayer service: "Give unto thy servants that peace which the world cannot give" and "Lighten our darknesse, we beseech thee, O Lord, and by thy great mercie defend us from all perils and dangers this night." 139 The poem opens with thanksgiving: "Blest be the God of love, / Who gave me eyes, and light, and power this day, / Both to be busie, and to play" (1-3). These lines recall "Matten's" heart empowering and continue the sight motif, which was a part of the intermediary "Sinne" (II). The human-divine connection relates to sin: "For when he [God] sees my waies, I dy: / But I have got his sonne, and he hath none" (7-8), with none referring both to sight (lines 5-6: "Who gave me sight alone / Which to himself he did denie") and the son. Here, the theme of insufficiency reappears - "What have I brought thee home / For this thy love? have I discharg'd the debt" (9-10) - but eventually gives way to weary acceptance, or perhaps a willing resignation to Christ's work. The poem's shift shows the oncoming night:

Yet still thou goest on, And now with darknesse closest wearie eyes, Saying to man, It doth suffice:

Henceforth repose; your work is done. (17-20)

"Darknesse closest wearie eyes" counters the opening lament of "Mattens" where the speaker cannot open his eyes. Despite italicization, the last line and a half of that excerpt do not have a direct biblical echo, though there is a tonal parallel to the Nunc Dimittis of departing in peace and having seen God's work ("for mine eyes have seene: thy 
salvation"). ${ }^{140}$ In "Mattens," the speaker prays to learn love. Toward the end of "Evensong," he "muse[s], which shows more love, / The day or night" (25-6) before one final moment of acceptance before resting:

My God, thou art all love.

Not one poore minute scrapes thy breast, But brings a favour from above;

And in this love, more then in bed, I rest. (29-32). ${ }^{141}$

The love of God grants the grace from above to descend on the speaker, but rests, per the opening line, more in God's love than in the bed. Rest stems from the comfort that God's love eventually leads to salvation and resurrection, which makes sleeps a peaceful metaphor for death. If rest represents death, then the calm acceptance at the end of "Even-song" makes for a smooth transition into the reflection of dust in "Churchmonuments," the following poem and first of the "furniture" poems.

"Church-monuments" is an odd meditational poem inspired by the funeral monuments inside the church. While the anti-Laudian would look for signs of rejecting the value of these monuments, Herbert, consistent with his view on images expressed in The Country Parson, finds value in using the funeral monuments to reflect on death. ${ }^{142}$ The central conceit of the poem plays on the $B C P$ 's Burial Service and the phrase "dust to dust" (made explicit in line 11: "Comparing dust with dust, and earth with earth") with its various biblical echoes in which the marble of the monuments separates the dust of the uncleaned church from the dust of the corpses within. What makes the poem odd or ironic is the body-soul division of the speaker. ${ }^{143}$ The opening allows for ambiguity: "While that my soul repairs to her devotion, / Here I intombe my flesh, that it betimes / May take acquaintance of this heap of dust" (1-3). Two options may exist: if alive, the speaker is in church, either praying or participating in the service; if dead, the soul awaits 
the rising of the bodies with Christ's second coming, and the body is learning from being surrounded by dust and other monuments. The influence of line 17, "Deare flesh, while I do pray, learn here thy stemme," leads many to prefer the first. ${ }^{144}$ If in the service, it seems odd for a worshiper not to dedicate their entire self to their devotion - if Herbert intended autobiography in this meditation, I presume this poem precedes his ordination, especially since The Country Parson objects to a dusty church. The repairing of the soul, either returning or mending, speaks to concerns present throughout The Temple. ${ }^{145}$ Another odd element to the poem is that the printers, contrary to the manuscript, chose to set the poem in six-line stanzas, reflecting the $\mathrm{ABCABC}$ rhyme scheme despite the grammar and punctuation not aligning to the form. Admittedly the effect is minimal: The first and second stanzas enjamb, but the lines "To sever the good fellowship of dust / And spoil the meeting" (13-14) come after a space, severing the meeting of the stanzas.

While the poem ends with a typical resolution of humbling the self before death, the middle of the poem contains an image that defies a straightforward reading. After admitting that death drives all to dust, the speaker continues:

Therefore I gladly trust [stanza break]

My bodie to this school, that it may learn To spell his elements, and finde his birth Written in dustie heraldrie and lines; Which dissolution sure doth best discern, Comparing dust with dust, and earth with earth.

These laugh at Ieat [jet], and Marble put for signes, [stanza]

To sever the good fellowship of dust, And spoil the meeting. What shall point out them, When they shall bow, and kneel, and fall down flat To kisse those heaps, which now they have in trust? Deare flesh, while I do pray, learn here thy stemme And true descent; that when thou shalt grow fat [stanza] And wanton in thy cravings, thou mayst know, That flesh is but the glasse, which holds the dust That measures all our time; which also shall 
Be crumbled into dust. Mark here below

How tame these ashes are, how free from lust,

That thou mayst fit thy self against thy fall. (6-26)

While the school metaphor is straightforward enough with the physical body learning from the dust and marble about life and death, the subsequent meditation on death becomes ambiguous. The poem personifies those elements of dust and earth: the dust that laughs at the marble monuments because eventually, time will dissolve the jet and the dust shall again commingle with the dust of the flesh. The personification continues to include gesture, with the subjective they of the elements giving way to the objective them of the monuments. Wilcox notes the duality of this image suggests the dissolution of the monuments will "lean, bend and eventually collapse" in a "process of increasing reverence, reminding us of the acts of prayer and devotion which are proper to being in church." ${ }^{" 146}$ While not Eucharistic, there is a weird communion in that the monuments eventually become the dust that they separate. The monuments reflect what the soul should be doing (e.g., the "kneeling in heart" in "Businesse") if they were not instead kissing the heaps of dust. ${ }^{147}$ Rhyme offers one reading: the flat monuments are linked to the fat, wanton flesh. While one scholar answers the speaker's question with another"Can there be monuments to monuments?" - the gesture, not explicitly condemned, seems to connect to the wanton cravings of the flesh that measures the time on earth. ${ }^{148}$ Alternatively, perhaps the speaker includes the gesture to mark how easily misled physicals acts can become when misapplied. The last three lines demand that the flesh should "Mark here below" that ash is inert, contain no pollution from lust, and prepare for death ("thy fall") by humbling itself before death - the very thing the monument represents. Because this is a meditation for the flesh, there is no Christly elevation or 
rising, which is reserved for the soul. By the end of the poem, it is apparent that the speaker uses the monuments as a school for meditating on the relationship of body and soul rather than an object of adornment or idolatry.

If "Church-monuments" contains an earth-bound meditation, then "Churchmusick" transitions away from the body to offer the soul wings in order to "know the way to heavens doore" (12). The three stanza, hymnlike poem addresses how music benefits the soul through an "Easter"-like joining with heaven. The poem does much to transition from the crumbling dust of "Church-monuments." After thanking the "Sweetest of sweets," the speaker identifies that

when displeasure

Did through my bodie wound my minde, You took me thence, and in your house of pleasure

A daintie lodging me assign'd. (1-4)

The "daintie lodging" recalls the Spirit's festive house in "Whitsunday," which suggests that music also contains a type of grace. If grace leads to salvation, as implied in "The H. Communion," the second stanza continues this image:

Now I in you without a bodie move, Rising and falling with your wings:

We both together sweetly live and love, Yet say sometimes, God help poore Kings. (5-8)

Wilcox reads "without a bodie" to mean a literal ecstasy, but also cites Hooker who writes music fills the body with a heavenly joy that separates it from the body. Moving without a body undercuts the carnal overtones of the "house of pleasure" and, with drawing in the poem's title, relocates it to the church. Wilcox also mentions contention over the line God help poore Kings. If Psalmic, the reference includes 118, part of the Whitsunday Matins and Evensong. ${ }^{149}$ The joys of the liturgy and song lead the speaker 
towards heaven's door, which, makes music, like the preceding monuments, a worship tool for the pious. A stereotypical Laudian reading of these poems overemphasizes the titles' physical components. Only in "Church-musick" does the title feature prominently in the text of the poem.

"The Church-floore" is more typical of the sequence, with the title-conceit giving way to the poem's internal meditations. As the final couplet makes clear, the floor represents the Christian's heart. But that internalization does not do away with external factors altogether. Like several other poems, "The Church-floore" demonstrates a concern with form and shape, with two distinct stanza forms. The first four stanzas focus on the floor itself. The first reads: "Mark you the floore? that square \& speckled stone, / Which looks so firm and strong, / Is patience" (1-3). While the shape is triplet, the rhyme spans two stanzas (ABCABC). Herbert, in each of the first stanzas, imbues the marble squares of the church with Christian virtues: strong patience, checkered humility, confidence rising into the Quire, with love and charity framed in "sweet cement" (10). The second half, however, changes meter as the floor becomes dirty. Against the virtuous floor, "Hither sometimes Sinne steals, and stains / The marbles neat" (13-14). Again personifying the weeping marble (15), the speaker brings in Death, who both blows dust and sweeps it up (16-18). The closing couplet reveals the temple-as-self metaphor: "Blest be the Architect, whose art / Could build so strong in a weak heart" (19-20). The poem offers thanksgiving for God, who, along with creating humans, created art that strengthens their heart. While the poem privileges the virtues, those virtues are nevertheless cemented and imbued onto the heart as and through art. Thus the "Churchfloore" joins both the literal and symbolic for edifying the Christian. 
The last of the "furniture-poems" is "The Windows," another instance where the title-conceit may be less important than poem's main theme of holiness inside the church. Though scholars note a long tradition of using "windows as conveyers of teaching and wisdom," the poem is less focused on learning from windows (cf. "Love-joy") than establishing a metaphor that places the preacher as the window through which heavenly light shines onto the congregation. ${ }^{150}$ The first stanza makes the metaphor clear:

Lord, how can man preach thy eternall word?

He is a brittle crazie glasse:

Yet in thy temple thou dost him afford

This glorious and transcendent place,

To be a window, through thy grace. (1-5)

While the second line highlights man's frailty in being brittle and crazie ("full of cracks"), ${ }^{151}$ the rest of the stanza (and poem) suggests an Andrewesian beauty of holiness. ${ }^{152}$ "In thy temple" locates the place of the preacher inside the church. In addition to being one of the few appearances of the word temple within the whole work, it may suggest that Herbert would frown upon extemporaneous public preaching outside of the temple. "This glorious and transcendent place" values the church building as a place of grace. The second stanza reads:

But when thou dost anneal in glasse thy storie, Making thy life to shine within

The holy Preachers; then the light and glorie More rev'rend grows, \& more doth win:

Which else shows watrish, bleak, \& thin. (6-10)

Line six alone suggests the glass itself is the didactic image, but the enjambment leads to the elevation of the holy preachers along with it. With the light growing more reverend (inside the church and on the preachers), the image recalls the unification of Christ and Christian through the resurrection, but here the union results in edifying preaching, the 
result of divinely inspired preachers. This also is a rare poetic statement that approaches explicit doctrinal belief:

Doctrine and life, colours and light, in one

When they combine and mingle, bring

A strong regard and aw: but speech alone

Doth vanish like a flaring thing,

And in the eare, not conscience ring (11-15).

Throughout the poem, the speaker makes clear that it is the union of God's Word and the Preacher that makes the sermon valuable. This last stanza, criticizing "speech alone," seems to contribute to the debate around sermon-centered piety. While the title-conceit focuses on the speaker, the poem's reference to the transcendent temple seems to imply that the reverence of the temple strengthens the sermon so that it is not empty speech. ${ }^{153}$ Combining this poem with the preparations and admonitions of "The Church-porch" and this sequence, the church offers a locus for the preacher's words to join with grace and God's Word in order to better make the auditor's conscience ring (as opposed to idly hearing words). This anti-idleness is consistent with The Country Parson, which Wilcox cites in annotating the poem's last line. Part of "The Author's Prayer before Sermon" reads " $\mathrm{O}$ make thy word a swift word, passing from the ear to the heart, from the heart to the life and conversation." 154 Ringing of the conscience, then, leads to concrete action.

In the Protestant church year, Trinity Sunday is the last major, Christocentric (inasmuch that Christ is part of the Trinity) festival until Advent begins; it is fitting then that Herbert's "Trinitie Sunday" marks the end of the various introductory sequences within The Temple. As with the Williams manuscript poem of the same name, the poem makes much of three, with three stanzas of three lines with the rhyme repeated in each stanza (AAA, BBB, CCC). ${ }^{155}$ The first stanza has an incarnational bent to it that links the 
speaker to the Godhead: "Lord, who hast form'd me out of mud, / And hast redeem'd me through thy bloud, / And sanctifi'd me to do good" (1-3). All three elements of the Godhead are present with God the creator, Christ the redeemer, and Holy Spirit as sanctifier. Christ's blood acts as the fulcrum that balances the stanza, as it is Christ's sacrifice that makes Christianity matter. This union permeates the entire poem, with the second stanza shifting the emphasis to forgiveness and confession: "Purge all my sinnes done heretofore: / For I confesse my heavie score, / And I will strive to sinne no more" (4-6). This stanza also sees a temporary shift of agency. While still addressed to the Lord, the fifth line shifts to the first-person subjective pronoun. In the last stanza, each line has its own trinity: "Enrich my heart, mouth, hands in me, / With faith, with hope, with charitie; / That I may runne, rise, rest with thee" (7-9). Here is the culmination of several earlier poems. We see the three virtues of faith, hope, charity (essentially what was in "The Church-floore") met with the actions of the enriched heart, mouth, and hand (the worship practices empowered through Easter). The last line alliterates the three verbs all verbs association with solar motions and Christ $^{156}$ - that also show the daily practice of "Mattens" and "Even-song" in the continual actions of the Christian seeking to rise with Christ's sacrifice. Without Christ's rising, akin to his blood in the first stanza, the rest of the actions would be meaningless. While the "enrich" me so "that I may" formula recreates the Easter union, it also reiterates that the speaker no longer seeks to compete with Christ's actions, but wants to work with Christ and through holy empowerment, which is the only way that the broken altar that opened The Church can be mended. Until the apocalyptic conclusion, I see no other sustained sequence in The Temple, which might reflect Van Wengen-Shute's notion that the liturgical emphasis in the introductory poems 
becomes less prominent as the speaker finds confidence in his art and devotional methods, with a slight exception for the poems at the literal core of The Temple. ${ }^{157}$

\section{VI. in medio templum: "Sion" and "The British Church"}

Near the halfway point in The Church, the reader comes across "Sion" and the “The British Church.” These poems, almost a miniature sequence, exemplify Herbert's ecclesiastical attitudes where the trim decoration of the English Church serves as an acceptable compromise between the excesses of Catholicism and puritanism. ${ }^{158}$ The meanness of decoration has parallels to his views on poetic language itself. It is fitting, then, that "Jordan" (II)'s rejection of "trim invention" and pretentious ornament begins or precedes this section (3). Immediately before "Sion" stands "Conscience," a poem that has drawn attention for its anti-asceticism and anti-puritanism. In it, the speaker rants against the "Pratler" $(1,7)$ who "lowre[s]" fair looks to foul, sweet dishes to sour, and music to howls (2-4). ${ }^{159}$ By listening to the prattler, the speaker has "both lost mine eyes and eares" (7), rendering him unable to work. Along with the rejection of the prattlers is the promotion of the effect of "My Saviors bloud" that "I do but taste it, straight it cleanseth me, / And leaves thee not a word" (15-16). The speaker clearly elevates the salvific power of Christ's "bloudie crosse" - a phrase a puritan might find overly Catholic - over the puritanical complaints (22). Thus, these poems show some of the favorable elements of ceremonial worship. 
On the other hand, some stereotypically Calvinist elements appear in "Prayer" (II), which both supports gesture in prayer and elevates prayer above physical means of worship. The first stanza reads:

Of what an easie quick accesse, My blessed Lord, art thou! how suddenly May our requests thine eare invade! To shew that state dislikes not easinesse. If I but lift mine eyes, my suit is made: Thou canst no more not heare, then thou canst die. (1-6)

The "quick accesse" of prayer contrasts the "dead" inventions found in the preceding "Jordan" (II) (line 10). Prayer, rather than human invention, leads to an audience with the divine. The logic of the line suggests that the speaker must "lift mine eyes" in order for the Lord to hear him - an echo, perhaps, of the end of "Redemption" where the speaker "espied" Christ on the cross to grant his suit (13). Where the first stanza emphasizes the ease of prayer, the next two elevate the power and love of prayer. The speaker concludes the poem:

Since then these three wait on thy throne, Ease, Power, and Love; I value prayer so, That were I to leave all but one, Wealth, fame, endowments, vertues, all should go; I and deare prayer would together dwell, And quickly gain, for each inch lost, an ell. (19-24)

That prayer has elements of ease, power, and love to it strengthens its role to the Christian, especially for the poetic project of mending the heart to accept divine love. In terms of this sequence, the forgoing of materiality concords with the inward spirituality that "Sion" will espouse. It is prayer, here contrary to the communal banquet of "Prayer" (I), that serves as a private act which enjoins supplicant and God into a beneficial relationship. As will be important with "Sion," the fact that Herbert makes prayer a 
private act does not supersede its communal benefit; it coincides. As one would presume from a via media, balance between extremes is key.

"Sion," like many other poems in The Temple, deals with transition. Unlike earlier poems where grandeur has Catholic or prelapsarian associations, the lessening of the sumptuous reflects the transition from the Old Testament's temple of Solomon to the New Testament's temple of the heart; it has likewise been read as the transition from Judaism to Christianity, Catholicism to Protestantism. ${ }^{160}$ In reading this as a Laudian poem, I argue that Herbert does not reject outright the ceremonial aspects (or the OT ceremonial law) but places them below the moral law that governs Christian actions. ${ }^{161}$ One relevant analog is Cranmer's “Of Ceremonies," which removes only those ceremonies deemed superstitious and warrantless. Read in conjunction with the "churchfurniture" poems, "Sion" shifts the focus from ceremonial ornament for its own sake onto what it does for the believer. Herbert avoids the controversy here by casually dismissing the temple and framing the poem around a less contentious subject - the devotion of the "peevish heart."

The transition in "Sion" occurs between the first and second stanzas. The first stanza in "Sion" shows what was - the building of the majestic temple in a previous age. It reads:

Lord, with what glorie was thou serv'd of old, When Solomons temple stood and flourished!

Where most things were of purest gold;

The wood was all embellished

With flowers and carvings, mysticall and rare:

All show'd the builders, crav'd the seers care. (1-6)

The language of the embellished temple has echoes of "Affliction" (I)'s fine furniture. If read typologically as a rejection of Catholicism, the gold, once dismissed, may also echo 
the rejection in "The H. Communion" of God's presence being conveyed through golden vessels. The last line shows the potential problem with the grandiose temple: it functions not to show the care of God, but of those who built and came to visit the temple. ${ }^{162}$ Intent matters, and, here, Herbert rejects those who value the temple as a symbol of (human) eloquence rather than a symbol of God's magnificence. This becomes apparent in the second stanza, with the shift to the internal:

Yet all this glorie, all this pomp and state Did not affect thee much, was not thy aim; Something there was, that sow'd debate:

Wherefore thou quitt'st thy ancient claim:

And now thy Architecture meets with sinne;

For all thy frame and fabrick is within. (7-12)

The first two lines of this stanza are often read as an absolute rejection of the external trappings of the temple itself. ${ }^{163}$ However, "not thy aim" and "did not affect thee much" do not dismiss the temple altogether but subordinate it to the inner fabric of groans and prayer. This is seen in the last couplet, which has multiple interpretations, whether architecture refers to man-as-temple contesting with Original Sin or if a Protestant "now" refers to the Catholic or Jewish temples overwrought with ornament. Accompanying the transition from external to internal is the value of man and God, and God values what is in the heart.

The second half of "Sion" reiterates the valuation of the heart to reveal that a sincere groan serves as a better externalization of the inner fabric than an empty monument. The final couplet of the third stanza perhaps best reflects the theme of the poem: "All Solomons sea of brasse and world of stone / Is not so deare to thee as one good grone" (17-18). Clearly, in the speaker's conception, God privileges groans over 
brassy temples. Yet, "not so deare" is not "not deare." The external temple by itself does not spur devotion. It requires something else. The final stanza speaks to this as well:

And truly brasse and stones are heavie things, Tombes for the dead, not temples fit for thee:

But grones are quick, and full of wings, And all their motions upward be;

And ever as they mount, like larks they sing;

The note is sad, yet musick for a king. (19-24)

Like the tomb in "Church-monuments," the golden temple in an earthy thing, weighed down with its physicality. On the other hand, the heart (or its groans) may be the "temple[] fit for" God, as the line itself is ambiguous enough to suggest that some temples - physical or aortic - may be fit for God. Unlike "Church-monuments," the speaker escapes the earthy and moves heavenward. Quick groans, perhaps recalling the quickness of prayer, have an association similar to the larks' ascendant song in "Easterwings." ${ }^{164}$ Regardless, the message of this poem is not antithetical to early Laudianism: external signs reflect internal reflection; they are not a substitute for it. ${ }^{165}$

With the previous poems speaking to the inward Christian, "The British Church" abruptly shifts gears to talk about the institutional church, one of Herbert's few poems on the topic. ${ }^{166}$ This poem epitomizes Herbert's moderation, though scholars disagree on how the purported via media functions - inclusively or as a critique against Catholicism and Calvinism, or just Catholicism. ${ }^{167}$ For as much as "Sion" purportedly rejects the external fabric of the temple, "The British Church" concerns itself directly with the lineaments of the church, so much so that Guibbory identifies the poem as "the clearest indication of Herbert's commitment to ceremonial worship." 168 The conceit of the poem places the British Church, the "deare Mother," as the perfect compromise between 
Roman Catholicism's superficial ornateness and Genevan Calvinism's zealous

nakedness. The first four stanzas establish the comparison:

I joy, deare Mother, when I view

Thy perfect lineaments, and hue

Both sweet and bright.

Beautie in thee takes up her place,

And dates her letters from thy face,

When she doth write.

A fine aspect in fit aray,

Neither too mean, nor yet too gay,

Shows who is best.

Outlandish looks may not compare:

For all they either painted are,

Or else undrest. (1-12)

Notably, the speaker takes joy through the viewing the presumably British lineaments (outside the title, the poem makes no explicit reference to the church's British identity).

Making no comment on whether this act is a sinful delight, the speaker's concern lies

only with the proper dress and the sweetness that beauty brings. The emphasis on beauty

aligns with an Andrewesian beauty of holiness in the church's worship: the speaker sees no superstition in this presentation of the via media. The church's "fine" and "fit aray" suggests a certain level of ornament can be appropriate. This perhaps echoes Cranmer's own moderation, though Wilcox cites The Country Parson, where Herbert also cites 1 Corinthians 14 and writes to "keep the middle way between superstition, and slovenliness." 169 Returning to the Platonic imagery of "Jordan" (I), cosmetics easily give way to falsehood. Within the British church's moderation, Herbert finds truth in beauty.

This moderation appears when compared to the polar extremes found on the continent. The following stanzas make clear that the "Outlandish looks" belong to Rome and Geneva. ${ }^{170}$ The second grouping of four stanzas compare how the Roman church, "She on the hills, ... wantonly / Allureth all" with her "painted shrines" that in turn make 
her face painted $(13-14,16)$ stands as the polar opposite to the Genevan church, "She in the valley" (19). The Calvinist extreme is "so shie / of dressing . . While she avoids her neighbours pride, / She goes wholly on th' other side, / And nothing wears" (19-20, 2224). Where the British Church preaches decency and order, the continental extremes lack both. The conclusion of the poem credits God with bestowing the British Church with her sense of appropriate meanness:

But dearest Mother, (What those misse)

The mean thy praise and glorie is, And long may be.

Blessed be God, whose love it was To double-moat thee with his grace, And none but thee. (25-30)

As in the "Church Militant," Herbert advances a providential view of the English Church, placing it as the standard bearer of the true church. God's grace comes not in overdecorated vessels but to a church not committed to zealous extremities. This is as close as Herbert comes in The Church to being polemical about the institutional church. Naturally, the conformist praises the writings of the church, but he does so without excessive belittlements of the opponents, so there is an attempt of politic behavior even if "none but thee" condemns all non-British churches. To read this poem in close proximity to "Sion" shows that the "perfect lineaments" of the church's moderate dress can bring pleasure to the Christian devotee. The difference between the two poems is that in "Sion," the outward stands by itself. In the last lines of "The British Church," the speaker acknowledges that the praise and glory of the church come from God - not those who build the church or her ornaments. Such a view is consistent with other early seventeenthcentury ceremonialists. 
VII. The Apocalyptic Culmination: "The Invitation" to "sit and eat"

The last sequence is an apocalyptic culmination of The Church, in as much as it concerns the judgment of the soul upon death. Like Stanley Stewart, I begin this sequence with "The Invitation" - however, because the first four of these poems were not in the Williams MS, like so many of the other sequential poems were, the "authorial intention" of this sequential unity may be dubious. ${ }^{171}$ Recalling the initial sacrificial-sacramental sequence of The Church, "The Invitation" reiterates the salvific importance of the Eucharist. The poem draws heavily on the $B C P$ Orders for communion, inviting all to partake in the Eucharist. Despite the refrain of "Come ye hither all," scholars read all stripes of theology in Herbert's Eucharistic invitation. ${ }^{172}$ Because the invitation is to all, not the predestined few, this call to partake with its salvific importance - "Come ye hither all, whose love / Is your dove, / And exalts you to the skie" (25-27) - aligns with the sacramentalism of the Avant-Garde Conformists. ${ }^{173}$ The next lines, "Here is love, which having breath / Ev'n in death, / After death can never die" (28-30), show the spirit (breath) of God instilling eternal life to all who partake. Bauer reads a pun on invitation, drawing upon the Latin vita, which makes this poem an invitation to the feast of eternal life, an apropos wordplay that begins the apocalyptic sequence with a communal feast before culminating in a private one. ${ }^{174}$

Integral to the invitation to partake is the transformative benefit of communion that turns sin into salvation. The poem illustrates this transformation through a juxtaposition of images in individual stanzas. Take the first two stanzas as example: 
Come ye hither all, whose taste

Is your waste;

Save your cost, and mend your fare.

God is here prepar'd and drest,

And the feast,

God, in whom all dainties are.

Come ye hither all, whom wine

Doth define,

Naming you not to your good:

Weep that ye have drunk amisse,

And drink this,

Which before ye drink is bloud. (1-12)

In the first stanza, the sinful taste contrasts the mending fare of the feast (in which God is present among the elements - an idea repeated in the third stanza); the well-dressed God matches the presumably bare sin. The second stanza turns to the wine, which, in

drunkenness, defines the sinner. Yet, through the sacrament, the blood-wine remedies the sin that was named not to good. In several ways, this poem fulfills "The Church-porch." Where earlier the poet preached moral behavior, the sacrament here transforms that immoral behavior to forgiveness and salvation. Similar comparisons continue in each stanza, until the final stanza varies the invitation: "Lord I have invited all, / And I shall / Still invite, still call to thee" underscores the speaker's logic that to bring someone to the Eucharist is to bring someone to (the presence of) God (31-33). The speaker concludes, "For it seems but just and right / In my sight, / Where is all, there all should be" (33-35). Wilcox reads "just and right" as an echo of the $B C P$ 's "meet and right so to do" call-andresponse in offering thanksgiving to the Lord. ${ }^{175}$ Thanksgiving would be an appropriate act, if all indeed can come and partake in the banquet and be unified with the Lord. ${ }^{176}$ This democratic openness is not limited to this poem; just four poems later, "The Elixer" - the first poem in The Temple since "Sion" to be in the Williams manuscript - declares "All may of thee partake" (13), with "thee" referring to "my God and King" (1). 
Herbert's preparation of the soul for death is not prejudicial and invites a communal attitude, even if "Love" (III) focuses on the individual.

"The Banquet," one of the few poems in The Temple to repeat the meter and rhyme of the preceding poem, continues the themes of "The Invitation," and may better exemplify the praise of the Eucharistic elements themselves. ${ }^{177}$ The opening stanza concretizes the desire for a literal presence between God and man:

Welcome sweet and sacred cheer, Welcome deare;

With me, in me, live and dwell:

For thy neatnesse passeth sight, Thy delight

Passeth tongue to taste or tell. (1-6)

"Sacred cheer" recalls "God is here / In this cheer" of "The Invitation." While Wilcox cites the $B C P$ 's prayer before consecration, which commemorates the eating and drinking of flesh and blood so "that we may ever more dwell in him, and he in us," the "passeth sight" and "tongue" also recalls the post-communion Benediction of "The peace of God, which passeth all understanding, keep your heartes and mindes in the knowledge and love of God, and of his sonne Jesus Christ our Lord." ${ }^{178}$ As the rest of the poem makes clear, this knowledge stems from the blood and the wine (the "Sweetnesse from the bowl" and the "Sweetnesse in the bread" in lines 7 and 13). The two penultimate stanzas again link the Eucharist with Easter-like salvation:

Having rais'd me to look up, In a cup

Sweetly he doth meet my taste.

But I still being low and short, Farre from court, Wine becomes a wing at last. For with it alone I flie To the skie:

Where I wipe mine eyes, and see 
What I seek, for what I sue;

Him I view

Who hath done so much for me. (37-48)

The stanza begins with another admonition to direct the gaze - though not necessarily at the cup - which seems to pick up on the Laudian focus on gazing toward Christ.

Contextually, the raising is a chiasmic distinction from the previous stanza's "God ... found me on the ground" $(34,36)$. While Wilcox and Hunter allege that "meet my taste" is a multilayered phrase that serves as the heart of the poem, I would note it, phonetically, inverts the invitation in "Love" (III) to "taste my meat" (17). ${ }^{179}$ "Farre from court" contextually refers to heaven, but there may be an urge to read it as Herbert's self-exile from court where wine may be the gateway to drunkenness, rather than the wing toward heaven. While this poem picks up on "Easter" themes (the layout of a stanza might be two wings laid oblong), the second stanza's "with it alone I flie" makes the Eucharist the grace from imbibing the wine - the most important part of Christ's sacrifice, for it is the enlightening grace that allows the speaker to fulfill his seeking of God by seeing God.

After "The Banquet," the sequence proceeds to the more overtly apocalyptic poems of "Death, "Dooms-day," "Judgement," and "Heaven," which question the relationship with God. Of these, I will focus on "Death" and "Dooms-day" with their low-high, dead-alive Christian dichotomizing, wherein the salvific importance of Easter is realized. Where "The Invitation" showed the transformation of the mortals through grace, "Death" shows Christ's sacrifice to have transformed the dull apparel of Death into a vibrant new array - an interesting image considering the various uses of dress and arrays throughout The Temple. At the start of the poem, Death is bare and almost naked: 
Death, thou wast once an uncouth hideous thing,

Nothing but bones,

The sad effect of sadder grones:

Thy mouth was open, but thou couldst not sing. (1-4)

The speaker paints what once was the insufficiency of mortal man onto death.

Theologically speaking, without Christ's sacrifice, groans would not wing their way to heaven as they do so often throughout the Temple. ${ }^{180}$ While Christ's sacrifice enlivens the believer, so too does it dress up death:

But since our Saviours death did put some bloud Into thy face;

Thou art grown fair and full of grace,

Much in request, much sought for, as a good.

For we do now behold thee gay and glad,

As at dooms-day;

When souls shall wear their new aray,

And all thy bones with beautie shall be clad. (13-20)

The truth in this beauty is that Christ's blood, sacrificial and sacramental, allows death and doomsday not to be occasions of woe and despair, but celebration. In "Doom," Herbert offers no singing or physical elevation, but the sense of beauty resembles what was seen in the Easter festivities.

That payoff, instead, appears in "Dooms-day." The opening of "Dooms-day" picks up on the "shells of fledge souls left behind, / Dry Dust" and the final "dust" of "Doom" $(11-12,24)$ and raises them: "Come away, / Make no delay. / Summon all the dust to rise" (1-3). Again picking up on apocalyptic imagery from Corinthians (see note 180 above), the speaker continues:

Come away, Make this the day. Dust, alas, no musick feels, But thy trumpet: then it kneels, As peculiar notes and strains Cure Tararntulaes raiging pains. (7-12) 
Like the dust in "Church-monuments," the mortal element of humans has no feeling and cannot feel the joys of salvation and resurrection. Dust (Wilcox: "humbled by the music of the trumpet") again kneels showing the humility of the mortal before the eternal. ${ }^{181}$ “This . . day" makes "Dooms-day" the Christian's Easter. The link to "Easter" themes reoccurs in the last couplet: "Lord, thy broken consort raise, / And the musick shall be praise" (29-30). The "decay" (26) of the flesh gives way to musical joy, so where "Easter" may have been a superficial poem of praise, the fulfillment of the significance of the day applies it more broadly. With this celebratory poem, the sequence turns confessional in "Judgement" before the heavenly feast in "Love" (III).

Though not technically the last poem of The Church - that honor extends to the Gloria postscript under the FINIS - "Love" (III) culminates the entire Church and Church-porch sections of The Temple. ${ }^{182}$ The poem answers the spiritual cleansing of The Church-porch, if at first reluctantly, and reaffirms the sacramental and sacrificial opening sequence with the speaker's final acceptance in "So I did sit and eat" (18). ${ }^{183}$ The poem captures the hesitancy in which the speaker relates that "my soul drew back" from Love's bidden welcome (1). After a mortal existence full of sin and unworthiness, how is the soul to respond to being sinless in heaven? The motif of the unworthy art of the speaker, not comparable or equal to God's, is not easily broken. The transition between the first and second stanzas shows the speaker's concern to avoid presuming to sit in the presence of Love: Love sweetly questioning, If I lack'd any thing. A guest, I answer'd, worthy to be here: Love said, you shall be he. (5-8) 
As seen throughout this dissertation, the controversy around sitting at communion was that it was too common an act that debased the reverence of the occasion. The speaker has internalized this attitude, as the immediate response to Love's judgment is to deny the estimation: "I the unkinde, ungratefull? Ah my deare, / I cannot look on thee" (9-10). Love reminds the speaker that Christ's sacrifice - "know you not, sayes Love, who bore the blame [for mortal shame]?" (15) - makes the soul a bidden guest worthy to sit. However, the response of the speaker exemplifies the Christian duty to serve because of Christ's sacrifice: "My deare, then I will serve" (16). ${ }^{184}$ This again is rejected through Love's gentle reproach of "You must sit down, sayes Love, and taste my meat" (17). Only then does the speaker relent: "So I did sit and eat" (18). One of the critical questions of this poem interrogates whether this is more a "communion poem" or a "love poem." The answer to that question often informs the importance of the verb sit. I am partial to Wilcox's compromise that "It is, of course, possible to see the poem as about both immediate and eternal feasts, particularly since the Eucharist itself functions as an earthly anticipation of the heavenly banquet." 185 The sequential logic suggests the eternal reading. While Herbert himself was a proponent of kneeling at communion, he here expresses an intimate banquet. The poetic fiction of this setting (though, for him, it was a depiction of what was to come) grants the poem a lenience that does not stake out polemical ground in the kneeling-sitting debate. Because Love made the speaker a bidden guest, no presumption or profanation occurs. Because so much of the sequence - of The Temple as a whole or the apocalyptic sequence itself - makes much of communion, there are other poems that emphasize the earthly act of communion. Nonetheless, from the sacrificial beginning to the final consumption, The Church emphasizes the importance of 
the sacrament for the believer: in order for the Christian to sit with God, they must confess and partake in communion. Liturgy grounds this process and leads to salvific joys - as made manifest in ending The Church with the Gloria: "Glorie be to God on high, and on earth / peace, good will towards men."

\section{Conclusion}

Most of the sequences in The Temple occur within The Church. The third and final part of The Temple, The Church Militant in some ways frustrates the attempt to read sequential unity in the entire work. "The Church Militant" brings the focus back to earth, tracing the evolution of Christ's church on earth. While the second finis and the printing of a trinitarian doxology recapitulate some of the liturgical ethos of the Gloria, the third section lacks sustained relevance to the project here. ${ }^{186}$ While the third section may suggest ways for the Christian to act as a part of the institutional church spreading the Gospel, Herbert's Laudian proclivities are more prominent in the first two parts of The Temple. The Church-porch focuses on moral actions, some of which are generalized while others orient themselves more directly to Common Prayer or sermon piety. Once inside The Church, the need to reflect on sinfulness and Christ's sacrifice and redemption becomes a prominent motif, with the sacraments offering the salvific solution and satisfaction for the inward meditations. A strong undercurrent of biblical liturgy pervades Herbert's lyrics, which provide instruction for readers and comment on the joys of Christian belief and practices. To return to the Veith epigraph that opens this chapter, Herbert's religion privileges and elevates moderation. His ecumenicalism invites readings 
from all Christians, as he avoids overt condemnation of any particular sect. To say he has

Laudian sympathies is not to say that he, like the stereotypical portrait of the Charles- and

Laud-led Church, wants all to be forced to worship as he does. In the spirit of "The

Invitation," all are called to participate, but, as the preceding lyrics make clear, the

willingness and efficacy of religious worship depends on the ability of individuals to

reflect on their own state and their relation to the creator, which is the didactic thrust of

Herbert's poetic project. It this relationship that edifies the heart and makes fruitful the

religious actions one undertakes in worship.

${ }^{1}$ Veith, Reformation Spirituality, 30, 39.

${ }^{2}$ Wilcox, ed., The English Poems of George Herbert, xxii. All quotations of Herbert's verse are from this edition, which, because of its relative recency (2007) and variorum-style commentary, I tend to cite the summaries of the secondary criticism tangential to my larger argument.

Methodologically, The Temple echoes the Sidney psalter, which uses the rigid frame of the Psalms, but employs 150 different verse forms. See also Fish, Living Temple, 26, where he talks of the divide between "order and unpredictability" in Herbert's verse.

${ }^{3}$ See for instance Frances Cruickshank, "Broken Altars: The Work of Form in George Herbert's Temple," Christianity \& Literature 66.1 (2016): 29-30, who characterizes the "pinning the poet down on doctrine" as "putting the cart before the horse." She is more interested in Herbert's formal games - where the idea of a "broken altar" embodies both the ideal perfection of form and the inability of form to reach such lofty ideals - than his doctrine. As a result, she simplifies the nuance what confessional identifies can mean. See for instance, 25: "At first glance, Herbert does seem like the pattern-card of high church formality and rigidity, playing with shapes and word games for no other purpose than to exercise his ingenuity." My argument goes against this view of Laudianism as formal, rigid, and soulless.

${ }^{4}$ As elsewhere in this project, while scholars often quote Calvin directly to show the influence, they often ignore the stronger influence on Herbert's contemporaries of second- and thirdgeneration Calvinists. Strier, Love Known, xi-xix, offers Luther as an influence, but connects Luther to Calvinism in a manner that suggests Laudian influences are anti-Protestant. Cf. Brian Cummings, "Prayer, Bodily Ritual, and Performative Utterance: Bucer, Calvin, and the Book of Common Prayer" in Prayer and Performance in Early Modern English Literature: Gesture, Word and Devotion, edited by Joseph William Sterrett, (Cambridge: CUP, 2018), 36, which cites Calvin's Institutes to show Calvin arguing that bodily gestures "are exercises whereby we try to rise a greater reverence for God."

${ }^{5}$ Parry, Arts of the Anglican Counter-Reformation, 133. Parry claims Herbert for the protoLaudians. For a Calvinist rendering of this tradition, see Doerksen, "George Herbert, Calvinism, and Reading 'Mattens," 437, or Christopher Hodgkins, "The Church Legible: George Herbert and the Externals of Worship," The Journal of Religion 71.2 (1991): 218-20.

${ }^{6}$ See Wilcox, xxxiii, for another overview. 
${ }^{7}$ For "Sacramental Puritanism," see Whalen's article of the same name. The epithet seems to assume a false dichotomy between word- and sacrament-centered piety. For the political legacy, see Sharon Achinstein, "Reading George Herbert in the Restoration," English Literary Renaissance 36.3 (2006): 430-65. I assume that Shuger, Habits of Thought, 12, had Herbert in mind when she wrote "both sides of any given contradiction may be held by a single individual, sometimes in a single work." See also Guibbory, "Devotional Poetry and the Temple of God," 102: "Many poems actually invite contradictory readings: from one point of view, they are about the inwardness of devotion; from another, they exalt the importance of priests and ceremonial worship. We might see such equivocation as Herbert's attempt to grasp the multiple aspects of devotion, but it is also a way of bridging differences, having his poetry speak to people on both sides of the controversy."

${ }^{8}$ Veith, "Religious Wars," 21. Strier in Love Known, Veith relies on the influence of Luther and continental Lutheranism to help explain the apparent disconnect between ceremony and inward devotion. That scholars still struggle with dichotomy, see comments by Swanner, 551, or Christopher A. Hill, “George Herbert's Sweet Devotion," Studies in Philology 107.2 (2010): 23658, or James Knapp, Immateriality and Early Modern English Literature: Shakespeare, Donne, Herbert (Edinburg: Edinburgh University Press, 2020), 230: "the reader is invited to find solid theological ground on the quicksand of Herbert's verse."

${ }^{9}$ This argument is similar to those who argued Herbert's poetry as being representative of the Jacobean via media, but, as subsequent citations will show, those scholars, like Ryrie, assume Laudianism is an exclusive movement of a minority fringe whose concern seems to lie exclusively with the external.

${ }^{10}$ The latter is discussed below. For avoiding controversy, see chapter 22 of Priest to the Temple, 92-93: "For the manner of receiving, as the Parson useth all reverence himself, so he administers to none but to the reverent. The Feast indeed requires sitting, because it is a Feast; but man's unpreparednesse asks kneeling. Hee that comes to the Sacrament, hath the confidence of a Guest, and hee that kneels, confesseth himself an unworthy one, and therefore differs from other Feasters: but hee that sits, or lies, puts up to an Apostle: Contentiousnesse in a feast of Charity is more scandall then any posture."

${ }^{11}$ This, perhaps, is in direct opposition to Doerksen, Conforming to the Word, 74-5: "Herbert's liturgical preoccupation has been greatly exaggerated, and that the Book of Common Prayer has effects on Herbert's poetry largely through its reinforcement of scriptural pattern." Given Herbert's proclivity, Priest to the Temple, 12, for the parson's "diligent Collation of Scripture with Scripture" and Ryrie, Being Protestant, 322-24, who contextualizes the $B C P$ as "propaganda for the Bible" and "a Scripture delivery mechanism," it seems asinine to distinguish the Bible from the $B C P$ when the sequential context of the poems has clear liturgical echoes in addition to the biblical allusions. The influence cuts both ways: yes, Herbert was scripturally minded, but he was liturgically minded too, and the English liturgy is almost nothing but scriptural pastiches.

${ }^{12}$ For my purposes, it does not matter whether the sequences were intentional. Fredson Bowers, "Herbert's Sequential Imagery: 'The Temper,"” Modern Philology 59.3 (1962), 202, may be the first to argue that Herbert's sequences are authorial and enhance our understanding of the poems on multiple layers, from the individual poem, to the sequential cluster, to the Temple as a whole. Louis Martz, The Poetry of Meditation: A Study in English Religious Literature of the Seventeenth Century, (New Haven: Yale University Press, 1954 [1962 reprint]), 292, argues a "sacramental introduction," but ends the sequence with "H. Baptisme" rather than "The H. Communion" as I do here. See also Fish, Living Temple, 123.

${ }^{13}$ Cf. Hodgkins, "The Church Legible," 229-30: "most of Herbert's poetic references to ecclesiastical externals are clearly metaphorical from the beginning, so that, while they reveal a mind favorably disposed to liturgical orderliness, they do not provide models for direct meditation on places and physical objects." While The Church-Porch concerns itself with models and moral precepts, the influence of the $B C P$ should be seen as informing Herbert's viewpoint. 
His poetry is not replicating the $B C P$, as they are two different genres (just as The Country Parson is a manual for preachers, rather than a devotional aid). Rosemary Van Wengen-Shute, George Herbert and the Liturgy of the Church of England, (Drukkerij de Kempenaer: Oegstgeest, 1981), 21, notes both a cursory and integral relationship with the liturgy. She also comments, 137, that Herbert's mysticism gradually takes him away from the liturgy which features so prominently in the first half of The Temple.

${ }^{14}$ Little Gidding is perhaps best known via Eliot's Four Quartets. It was attacked in an anonymous Puritan pamphlet titled The Arminian Nunnery (London: 1641). Cf. Cosin, pages 4-5 of the pamphlet attack Little Gidding for its use of the IHS inscription with a cross, "the proper Character of the Jesuites in every Booke and Exhibite of theirs." Izaak Walton's biography also establishes an Anglicanization of Ferrar, to which Hodgkins, "The Church Legible," 224, and Doerksen, Conforming to the Word, 43, object on account of his, citing Doerksen, "emphatically Protestant faith and his non-Arminian associations."

${ }^{15}$ See Wilcox, 39-40, for uses of the temple as a Jewish cite for worship, a New Testament symbol of Christ, the Christian church symbolically succeeding the Old Testament Temple, and the human body as temple for Christ to Dwell. John Drury and Victoria Moul, eds. George Herbert: The Complete Poetry, (New York: Penguin, 2015), 360-61, suggest Ferrar's script in the Bodleian manuscript labeling "The Temple" on each page makes the title his invention, while "Sacred Poems and Pious Ejaculations" more closely resemble Herbert's intent. Barbara Lewalksi, Protestant Poetics and the Seventeenth-Century Religious Lyric (Princeton: Princeton University Press, 1979), 135-42, offers other typological readings of the temple resonant with Wilcox's summary.

16 "Divine majesty" is the phrasing of The Printers to the Reader (Wilcox, 42); Herbert's "The Dedication" simply addresses God as "Lord" in line 1.

${ }^{17}$ Wilcox, 42-43. She notes that dignity refers to his Bemerton prebendary, where he renovated the church and tried to pass the credit for that onto Ferrar. Chapter 13, A Priest to the Temple, 5759, is "The Parson's Church" which has strong echoes of the $B C P$ (Cranmer) and the 1604 Canons in which "all things there be decent" having taken "order, that all things be in good repair" including walls, windows, the floor, seats, pulpit, communion table and font. He also writes that the church should be cleaned of dust" (Cf. "Church-monuments"), "that images be grave and of scripture, and that the appointed books be present." This is done not to put "a holiness in the things, but as desiring to keep the middle way between superstition, and slovenliness" as seen through adherence of 1 Corinthians 14, where all things are done decently and in order and to edification, as "these two rules comprise and include the double object of our duty, God, and our neighbor." Hodgkins, "Church Legible," 222-23, cites this as evidence of a Protestantly Calvinist Herbert, though this is the same source for Laudian ceremony. Watt, 132, categorizes "radicals" who condemned "images in themselves" in addition to "'abused' images" and "moderates [who] were primarily cocnered with images in churches" - Herbert aligns with the moderate depiction in this case.

${ }^{18}$ Wilcox, 45-46.

${ }^{19}$ Wilcox 46. It is her annotation that "make again" means rereading. She does not relate the financial imagery to the first line, but turns to "The Pearl" $(13,34-5)$ and the opening stanza of "The Church-porch."

${ }^{20}$ I was mildly disappointed to discover that Veith, Reformation Spirituality, 57, makes a similar claim about "The Church-Porch" preaching the Law as "essential preparation" for Christ's Gospel in "The Church," though he does not emphasize the ceremonial elements. This is just one of a number of purported archetypal relationships: see Wilcox 47-9 for a sampling of critical perspectives. Doerksen, "Preaching Pastor," 419-420, identifies a confessional difference in that Calvinists prefer preaching the Gospel while Laudians prefer preaching the Law. (Such a dichotomy ignores the relationship of the law to the Gospel). 
${ }^{21}$ Wilox, 48, cites Elizabeth McLaughlin and Gail Thomas, "Communion in The Temple," Studies in English Literature, 1500-1900, 15.1 (1975): 111, who compare the "Church-Porch" to the "proverbs and laws of the Old Testament" and suggest that the 77 stanzas could correspond to the 77 words in the creed.

${ }^{22}$ Dyck, 543: "The poem goes on to warn the reader against vices, including lust, drunkenness, boasting, and idleness, and proceeds to summarize good conduct in all aspects of life, before concluding with instruction for going to church, calling for reverent behavior both external (403ff.) and internal: 'Christ purg'd his temple; so must thou thy heart' (423)."

${ }^{23}$ My use of the italicized The Church-porch refers to the section, while the words inside quotation marks refers to the poem itself. Scholars are inconsistent on the differentiation, but few seem to refer to the poem by its subtitle Perirrhanterium. Wilcox, 63 cites Mary Ellen Rickey, Utmost Art: Complexity in the Verse of George Herbert, (New Brunswick: Rutgers University Press, 1966), 6, who notes the distinction between the Greek Perirrhanterium and the Catholic aspergillum.

${ }^{24}$ Wilcox, 86. For Herbert, profaneness does not discriminate between laity and clergy. See "Aaron" which distinguishes "Holinesse on the head" of "true Aarons drest" $(1,5)$ to the "Profaneness in my head ... Poor priest thus am I drest" $(6,10)$ before admitting the new and well drest of those who take Christ as the "onely head" who renews the old and profane defects of all humans.

${ }^{25}$ See variously Wilcox, 64, Kronenfeld, 74, or John Bienz, "Images and Ceremonial in The Temple: Herbert's Solution to a Reformation Controversy," Studies in English Literature, 1500190026.1 (1986): 80.

${ }^{26}$ There are 77 stanzas, each of which is an ABABCC sestet. For instance of repeated themes, the fourth stanza rails against drunkenness and not drinking the third glass. Drunkenness or wine then appears in the four following stanzas (and the third glass appears in the fourth of the five stanzas). ${ }^{27} \mathrm{I}$ am not the first to suggest interplay between epigrammatic poetry and sermons with this poem. Wilcox, xxx, cites Wendy Cope's descriptions, George Herbert: Verse and Prose (London: SPCK, 2002), xx, of the "The Church-porch" as a "rhyming sermon," a "Self-help manual," and "brilliantly epigrammatic verse."

${ }^{28}$ Wilcox, 63, cites Ben Jonson who called Bartas a verser rather than a poet because he did not write fiction; she also cites the OED to equate verser with a swindler.

${ }^{29}$ Wilcox, 64, cites Ch. 21 of A Priest to the Temple to record Herbert's complaint of men who may "sleep or wander" during a sermon." Such a critique goes hand-in-hand with the Laudian complaints of idle sermon-goers - and is a thing Bayly, for instance, advised against.

${ }^{30} \mathrm{Cf}$. Fish, Living Temple, 25-26, where he suggests the relationship between poet and reader is akin to catechist and pupil, or 49, commenting on these lines "It is not simply that in both texts a comparison is made at the expense of sermons, but the virtues of poetry and catechizing are the same: they do not allow the reader-auditor to be passive . . . he is asked to make a sacrifice, that is, to perform both an act of holiness (a communion) and an act of submission." Fish's use of the catechistical method resembles the Laudian drive for doing. On the adaptations of Herbert's verse in other types of texts, see 51-52.

${ }^{31}$ Anne Myers, "Restoring 'The Church-porch': George Herbert's Architectural Style," English Literary Renaissance 40.3 (2010): 439-40 and 455.

${ }^{32}$ Regarding behavior at the Eucharist, however, Herbert endorses kneeling, but not so much as to make it controversial. In Priest to the Temple, Herbert endorses kneeling in prayer and reverent communion in chapters 6 ("The Parson Praying"), 10 ("The Parson in his house" - where he invites visitors to kneel in prayer), and most notably 22 ("The Parson in Sacraments"). He also, 89, advocates the Parson "cheerfully crosseth the child" in Baptism because he "thinketh the Ceremony not onely innocent, but reverend." Appealing to the liturgy and other devotional material, Herbert likely thinks that all humans should come to the Eucharist meditating on their unworthiness but does note that feasts properly deserve sitting. Because he seeks to avoid 
contention, he does not belabor the point, but overconfidence and "put[ting] up to an Apostle" seems to speak to over-presumption of one's position in relation to Christ. Hodgkins, "Church Legible," 239, also states that "Herbert would never 'sit and eat"' (his emphasis).

${ }^{33}$ Wilcox, 80-81. She suggests "six and seven" could refer to small praying groups or be a reference to carelessness in gambling. "brave, adj., n., and int.". OUP: OED Online. June 2020. The "showy" denotation comes through the Scottish braw, which has a second definition of excellent and worthy that is also relevant.

${ }^{34}$ Doerksen, Conforming to the Word, 90-91, sees these lines reflecting Hooker's privileging public over private prayer.

${ }^{35}$ Prayer also is "a kinde of tune" (8) presumably heard as "Church-bels beyond the starres heard" (13) which ties into both "The Knell" (Williams manuscript) and the reference to the bell in "The Church Porch" 387-88. The line "Heaven in ordinarie, man well drest" ties into lines 410. This also perhaps draws in lines 387-8, "Sundaies observe: think when the bells do chime, / 'Tis angels musick; therefore come not late," where bells are a sign to observe the Sabbath (cf. Hodgkins, "Church Legible," 232, which takes the "The Knell" as the only "'Anglican' meditation"?).

${ }^{36}$ Wilcox, 81, provides this gloss without referencing the OED, and cites that Puritans and Quakers wore their hats in church to flaunt the authority of the church. "bare, adj., adv., and n.". OUP: OED Online. June 2020.

${ }^{37}$ Wilcox, 81: "Humility in church is appropriate even for those of elevated social status."

${ }^{38}$ For Bayly, see chapter 3 above. Lake, "Lancelot Andrewes," 125. He continues, in line with Herbert's "Prayer" poems (see below), that prayer, together with sermons, link God to man and man to God. See also Fincham 232-33, on the Arminian promotion of prayer. Cf. Doerksen, Conforming to the Word, 67-8, that argues "That pronouncement [in lines 409-10] should be balanced off by others in the poetry, and by what Herbert says in his prose work." However, as Bienz, 80 argues, audience matters: the intended reader of "The Church-porch" is not the country parson of Herbert's preaching manual.

${ }^{39}$ OED 2a, 1a, and 1b, respectively. 1b, however, specifies "a course of action, esp. an extreme or undesirable one, in order to resolve a difficult situation." If Herbert was following the literal sense, the appositive extreme/undesirable would have a weird ironic undercutting to it. "resort, v.1". OUP: OED Online. June 2020.

${ }^{40}$ Davies, Caroline Captivity, 67-68, quoting Works of William Laud, vol 6., edited by J. Bliss and W. Scott (Oxford: 1847-1860), 114-15. The citation of Davies merits a mention of methodology: he continues, on the basis of Herbert placing his reading-desk opposite the pulpit in Leighton Bromswold) to say that sermons and prayer for Herbert are equal, whereas Laud favors prayer. This poem, however, suggests that prayer is more important, although Davies does not provide the context for whom sermons and prayers are more important - for preacher or parishioner.

${ }^{41}$ Wilcox, 81.

${ }^{42}$ Wilcox, 82-3. She also notes that accounts works both on the level of narrative (of what you have to do/have done) and financially (making the debits and credits agree).

${ }^{43}$ On "The Altar" as title page, see Lynch, "George Herbert's Holy 'Altar,' Name and Thing" or Dyck, passim. Dyck, 569, notes the Laudian potential of "The Altar," especially because a sacrifice demands a priest. See also Guibbory, Ceremony and Community, 46-47, who suggests the poem speaks to the Laudian Altar policy (which did not begin until 1637).

${ }^{44}$ In looking just at the titles in The Church, the liturgical year appears in order, starting with Holy Week, before progressing to Easter, Whitsunday, and Trinity Sunday, which is then followed by poems for Christmas and Lent. Thematically, a second Holy Week sequence appears with "Longing" and "The Bag." See Wilcox, 521 and Rosemond Tuve, A Reading of George Herbert (Chicago: University of Chicago Press, 1952), 129, for the Eucharistic significance of the latter poem. 
${ }^{45}$ Guibbory's claim, Ceremony and Community 50, that "'The Altar' seeks to avoid the worship of the self, or 'will-worship' as puritans called it" may be undercut if we read the shape of the poem as a giant $I$, though, again Herbert's ironies eschew any one interpretation. Much work has also been done on Herbert parodying earlier traditions of altar poems. She suggests, 46-7, that the capitalization of Altar and Sacrifice may have triggered puritan antipathy to Roman and Jewish rites.

${ }^{46}$ Watt, 134, outlines radical and moderate divisions of iconoclasm and iconophobia among English Protestants.

${ }^{47}$ See Dyck's discussion, 546-50, where he suggests the altar may be poetic or liturgical and raises questions about human presumption toward the divine; see also Strier, 192-95.

${ }^{48}$ Hannibal Hamlin, Psalm Culture and Early Modern English Literature, (Cambridge: CUP: 2004): 201-202. Quoted in Dyck, 559.

${ }^{49}$ Most notably, perhaps, in "Jordan" (I), but multiple poems question the value of human eloquence.

${ }^{50}$ For overview and further analysis of the use of Lamentations as well as commentary on scholarship that sees this poem as engaging with Catholic and Jesuit tradition, see Wilcox, 94-5 and 104.

${ }^{51}$ McCullough, "Transforming Passions," 585, notes the use of the Improperia by Andrewes and his tendency in his Lenten sermons to create "verbal crosses" amidst an iconoclastic age.

${ }^{52}$ One of the ironies of the poem consists in Christ lamenting his sacrifice benefiting all mankind except for himself. See variously, 27: "Curing all wounds, but mine; all, but my fears"; 203: "the tree of life to all, but onely me"; 225-7: "In healing not my self there doth consist / All salvation, which ye now resist; Your safetie in my sicknesse doth subsist."

${ }^{53}$ See overview, Wilcox, 95. If Herbert is aligning with Catholic meditational practice, that does not necessarily invoke a Laudian sense of tradition (cf. Reformed sense), as many early English devotionals were translations of Catholic texts. Also worth noting is Ryrie, Being Protestant, 289, who argues most Protestant treatments of the passion focused on the mental anguish rather than affective. For another Eucharistic reference, see lines 119-20: "I the prince of peace; peace that doth passe / All understanding," an echo of the BCP Eucharistic blessing, derived from Philippians 4:7.

${ }^{54}$ Herod's Greek title, Latinized as Antipatros is more commonly rendered Antipas. It means "like the father" rather than "against the father." It is notable that Wilcox has no annotations for these lines.

${ }^{55}$ See also line 90: "If stonie hearts will melt with gentle love" which seems to recall "The Altar."

${ }^{56}$ See Wilcox, 107, who brings in the disagreement between Tuve's liturgical reading and Empson's straightforward reading of Christ not being a political agitator.

${ }^{57}$ Wilcox, 109.

${ }^{58}$ Philippians 2:10 and 11. Much of the chapter frames this worship after Christ's humble incarnation into a servant who died on the cross, which God turned into a moment of exaltation (2:5-12).

${ }^{59}$ The Prosperity Gospel (along the lines of those televangelists who say God will reward you for tithing to their church) is of course anachronistic. Wilcox, 111-12, describes the speaker as a zealous follower of God, but who lacks Christian knowledge. She also gives an overview of scholarship that sees this poem as a critique of Catholic devotional tradition in favor of Christian humility as expressed in Protestant spirituality.

${ }^{60}$ Wilcox, 115, reads this line as an ironic reference to Ovid's Ars Amatoria, which is itself an ironic how-to manual in winning the game of love. Ilona Bell, "'Setting Foot into Divinity" George Herbert and the English Reformation," Modern Language Quarterly, 37 (1977): 235, reads this as Herbert turning from the image of Christ crucified toward the Bible - from Catholicism to Protestantism. 
${ }^{61}$ It probably bears mentioning that line nine (“My God, my God, why dost thou part from me?") recreates the entire verse that "The Sacrifice" line 215 cuts short. The speaker can quote the scriptural referent because he does not adequately feel the grief that Christ does and did while on the cross.

${ }^{62}$ J. Max Patrick, The Editor as Critic and the Critic as Editor (Los Angeles, CA: William Andrews Clark Memorial Library, 1973), 15-16. Cited by Wilcox, 116. In the Williams manuscript, the first part of "Good Friday" - which I allege is more cruciform than this - follows this poem instead of "The Agonie" and "The Sinner" as in The Temple.

${ }^{63}$ Wilcox, 117.

${ }^{64}$ As noted by Wilcox, 119.

${ }^{65}$ Wilcox, 120, cites the intervention of Todd who compared Herbert's violent press with the Schola Cordis emblem, which was also used by Andrewes in his 1605 Good Friday sermon as a metaphor for the cross. This linking, based on looking upon Christ, recalls McCullough's "Transforming Passions," which also called for an active looking upon Christ's crucifixion as a tool for meditation. On the Isaiah epistle, see Wilcox 118, 120-21, and the BCP, sig. E5r-v.

${ }^{66}$ Wilcox, 126.

${ }^{67}$ Wilcox cites both Luke 2:7 and line 7, where "one starre show'd thy first breath."

${ }^{68}$ See, for instance, Andrewes's Christmas and Whitsunday sermons. See also Anne-Marie Miller Blaise, "“Sweetnesse readie penn'd': Herbert's Theology of Beauty," George Herbert Journal 27.1/2 (2003/2004): 2 and 6, for the influence of the Byzantine Fathers to show Herbert's use of Incarnational theology for the "reaching down of God towards humanity" through aesthetic images.

${ }^{69}$ See Featley's citation of Leo's "He that is not more religious in Lent then at other times hath no religion at all" in Chapter Two above.

${ }^{70}$ Hodgkins, "Church Legible," 236-37. Cosin, ed. Stanwood, 199.

${ }^{71}$ Hodgkins, "Church Legible," 233. Hodgkins argues that the "lesson" of these poems is that the absence of "Easter" is its ubiquity to everyday, Christian life. While I think this is generally true, it is not the case for "Easter" and "Easterwings." "Praise" (II)'s declaration that "Sev'm whole days, not one in seven, / I will praise thee" (17-8) or the Easter imagery in "Sunday" better supports the argument: "O day most calm, most bright. . . writ by a friend, and with his bloud" (1, 4); "The week were dark, but for thy light ... This day my Savior rose, / And did inclose this light for his" (6; 36-7); "Sundaies the pillars are / On which heav'ns palace arched lies: / The other dayes fill up the spare / And hollow room with vanities" (21-5); and "The Sundaies of a mans life ... Make bracelets to adorn the wife / Of the eternall glorious King" (29, 31-2). Sunday, as an elaborate and ornate day, reflects the glory of Christ's sacrifice and resurrection. $721604 B C P$, sig. G2r-v. Wilcox, 151, cites this collect as part of the source material for "H. Baptisme" making connections between Baptism and Easter, but does not cite it in relation to this poem.

${ }^{73}$ As noted by Wilcox, 138, 140-41.

${ }^{74}$ Tuve, 144-45. She connects this conceit to the Speculum humanae salvationis, where Christ is extended as a harp. Salve Festa Dies (Hail, festival day) is a hymn that praises the festival day, the restoration of earth and nature, Christ's triumph (a muted element in Herbert's poem), and the now-rescued humanity.

See also Hymn Descants.org 's "Salve Festa Dies," April 2019, https://hymndescants.org/salvefesta-dies, (accessed Feb. 23, 2021), or Catholic Culture's "Easter Hymn," 2021 https://www.catholicculture.org/culture/library/view.cfm?recnum=124 (accessed Feb. 23, 2021).

${ }^{75}$ Wilcox, 141. She also notes, 142, that "most high day" may reference sacred hymns being keyed higher than madrigals and secular music, for a "sweet-sounding" effect.

${ }^{76} 1604 B C P$, sig. G3v. Wilcox, 141, notes the OED's "just note" that precedes the musical imagery of the next stanza and cites an accordance with Milton's "To Mr. H. Lawes" third line with its "just note and accent." 
${ }^{77}$ Strier, 59, makes the connection between the second half of "Easter" and the Marys of Mark 16.

${ }^{78}$ Wilcox, 140, comments on communion during the church year. Herbert's use of the lute suggests that he favors instrumental music, which would align him with Hooker (see Lawes V.XXXVIII.159: "A thing which delighteth all ages and beseemeth all states; a thing as seasonable in grief as in joy; as decent being added unto actions of greatest weight and solemnity"). More tendentiously, one could argue that the union and harmony between Christ and man in song are allegorical for the sacraments, which for Hooker, V.L.3.219-220, "concern a far better life than this" and "are the powerful instruments of God to eternal life. . . our life supernatural in the union of the soul with God" which is made possible because "the Sacraments do serve to make us partakers of Christ." Herbert's later poems "Christmas" and "Ungratefulness" play with similar themes of ornateness in language and celebrating the union between man and Christ.

${ }^{79}$ While I do not have much else to say about the shape of the poem, John Poch offers a fairly unique reading that, under the influence of the Williams manuscript, argues for a right-justified layout that precludes reading the poem as an hourglass in "Birds of a Feather: George Herbert's "Easter-wings," Christianity \& Literature 68.3 (2019): 475-490. He argues the resultant white space gives room to God's presence and might be an arched wing, so that a non-textual set of wings matches the poem's text. Other scholars have read the influence of Psalms 68:13 (a silver winged dove) to make reference to priests, referring to the priestly function of both Herbert himself as well as Christ, see Wilcox, 147 or Tuve, 157. Wilcox, 148, cites F. D. Klingender, Animals in Art and Thought, (London: Routledge \& Kegan Paul, 1971): 371, 444, who reads "larks" as the Latin alauda to reference praise (laud) and a symbol of both priesthood and humility.

${ }^{80}$ This repetition doubtlessly falls into Fish's paradigm, 27, of The Temple as catechism, with the repetition of themes serving as a type of corrective questioning.

${ }^{81}$ Wilcox, 148.

${ }^{82}$ Wilcox, 148.

${ }^{83}$ This process - focusing on the external and moving inward - resembles Fish's "catechistical" method, 44, where the pupil first faces what "is known" (in Scripture) and must self-discover or be led to "interiorize its significance."

${ }^{84}$ Other sacramental sequences have been identified. Martz, 292, for instance, notes a "Sacramental Introduction" to The Church that ends with "H. Baptisme" rather than "The H. Communion." This is cited in Wilcox, 154.

${ }^{85}$ Cf. Wilcox, 153, cites Leah Marcus, Childhood and Cultural Despair: A Theme and Variations in Seventeenth-Century Literature (Pittsburgh: University of Pittsburgh Press, 1978), 101-04, who sees the stanza form of "H. Baptisme" (II) as the "pattern of grace" and identifies an outsideinside dynamic between the two poems to show the "transmuting effects" of baptism.

${ }^{86}$ Wilcox, 149, also cites the $B C P$ baptismal service and the Easter week collects. See also Andrewes, Sermon . . Easter last, 48-50, who connects baptism to Easter. On another liturgical note, the resolution of "H. Baptisme" (II) that "Childhood is health" (15) reflects Jesus's admonition to receive the kingdom of Heaven as children, which appears in Mark 10:14-15. Mark 10 serves as the $B C P$ Gospel reading for Public Baptism.

${ }^{87}$ Lake, "Laudian Style," 174; see also Milton, Catholic and Reformed, 470, which argued for the emphasis Avant-Garde Conformists "placed upon the importance of liturgical ceremonies and the sacraments as fountains of grace."

${ }^{88}$ Wilcox, 150, cites two formal interpretations. Summers argues Herbert inverted the octet and sestet - the first six lines are a backwards reflection and the "octet" redirects towards a Christ-like apostrophe. Ottenhoff maintains that, despite the unconventionality, the sonnet is "firmly balanced and controlled." 
${ }^{89}$ Wilcox, 153. Each stanza has lines of 4, 8, 10, 8, and 4 syllables. Unlike "Nature" which has an almost mirrored orientation, the word heart does not appear. Baptismal shells may date to the $12^{\text {th }}$ century and were used assigns of pilgrimages (the journey in this poem is figurative), but they do not appear in the $B C P$ - sig. N8r (1604) allows for children to be dipped or have water poured over them but does not mention what tool the priest should use. On the $12^{\text {th }}$ century origin, see "Shell," Catholic Culture, 2021, https://www.catholicculture.org/culture/library/dictionary/index.cfm?id=36454, (accessed Feb. $23,2021)$. On the role in pilgrimages, Thomas, Waldron, "The Sign of the Scallop Shell," The Furrow 30.10 (1979): 646.

${ }^{90}$ Wilcox, 160, cites Bell "Setting Foot," which argues for Herbert's churchmanship with a focus on custom rather than doctrine. This article focuses on Herbert's increasing Protestantism as distinguished from the Catholic modes of devotion found in his earlier poems. She does not mention "Affliction" (I). However, in "Revision and Revelation" 78, she argues "Herbert's sympathies [in "Affliction" (I)] turned away from Hooker and the high Anglicans toward Calvin and the reformers." Bell equates the poet's fascination with material wealth with the church finery of the first stanza. Her argument, 87 , assumes that the notion of humility preceding from faith is distinctly Calvinist. She also, 89 , sees Herbert finding resolution in the Bible, although the poem does not make that distinction clear.

${ }^{91}$ Its linear structure: the speaker is first enticed and lives in pleasure and sweetness (lines 1-22), then begins to pain in sorrow (23-26) before moving to an unfulfilling academic life (37-54), before ending in a temporal present (55: "Now I am here") with an uncertain outlook on the future where the speaker declares "I will change the service, and go seek / Some other master out" (63-4) before ending with an abrupt, paradoxical apostrophe to God, writing "though I am clean forgot, / Let me not love thee, if I love thee not" (65-66).

${ }^{92}$ Wilcox, 164.

${ }^{93}$ E.g., Doerksen, Conforming to the Word, 35: "the Laudians were more interested in simply imposing outward order" as opposed to care for spiritual well-being or religious discipline (his emphasis).

${ }^{94}$ Wilcox, 168, notes that the Williams MS has "Ah my deare King" for The Temple's "Ah my deare God" in line 65.

95 The conceit of "Affliction" (V) of Original Sin avoids the Laudian or Catholic potential present in "Affliction" (I): "At first we liv'd in pleasure; / Thine own delights thou didst to us impart: / When we grew wanton, thou didst use displeasure / To make us thine: yet that we might nto part, / As we at first did with thee, / Now thou wouldst taste our miserie" (7-12). A similar image appears in "Decay" (I), where Herbert writes of God's interactions with Old Testament figures: "Sweet were the dayes, when thou didst lodge with Lot" (1).

${ }^{96}$ Cf. "Sion." While "Affliction" (I)'s seeking another master seems to be replicate "did not affect thee much," it does not make explicit that the groans of affliction are pleasing to God.

${ }^{97}$ Wilcox, 165.

${ }^{98}$ Wilcox, 167. Read literally, this might negate Bell's argument about turning away from the crucifixion (viewing the crucifixion as Catholic devotion).

${ }^{99}$ See Chapter One above, or Buckeridge, A Sermon, 12, 17, or 26.

${ }^{100}$ Wilcox, 169, notes the echoes of the Penitential Psalms and cites Wengen-Shute's observation of Psalm 39's use in the Burial of the Dead Service, 171, identifies line 15 as a conflation of Psalm 51 and suggests the confession of foolishness might be a specific reference to the final stanza of "Affliction" (I).

${ }^{101}$ Wilcox, 180, compares line 10 to the Catholic elevation of the Host as well as lifting Christ up on the cross.

${ }^{102}$ Wilcox, 181-2, provides the overview. Miller comments the revision of the last stanza from the Williams MS shifts the emphasis from prayer to communion, makes "the prayerful observations sacramental ones," and makes the feeling/meaning dichotomy. Freer argues the first 
half of the poem is more complex (10-6-6-8-6, ABBACC) while the back half has a "simple form" - quatrains in 8.6.8.6 $\mathrm{ABAB}$ hymn meter.

${ }^{103}$ Wilcox, 184.

104 "Sacramental Puritanism," 1287. In a footnote, he dismisses an earlier interpretation of Clarke that "discerns a dual motion of outward form toward inward spirituality and the subsequent movement of the grace-inspired soul toward heaven" separated by the two parts of the poem because he sees it in in "the first half alone."

${ }^{105} \mathrm{Cf}$. McLaughlin and Thomas, 116: "The meaning of communion in the largest sense includes prayer to a personal deity, mystical experience of union with the divine, participation in the body of Christians, acceptance of forgiveness through Christ, and the sacrifice of self."

${ }^{106}$ Noted by Wilcox, 185.

${ }^{107}$ As in the $1604 B C P$, sig. N4r.

${ }^{108}$ As discussed in Wilcox, 186-87.

${ }^{109}$ As noted by Wilcox's annotation to "Jordan" (I), 203.

${ }^{110}$ The sequence could begin with "Antiphon" (I). I am not the first to designate such a sequence: Bowers, 202-13, delineates the sequence with the "Love" poems establishing the appropriate poetic subject, the "Temper" poems establishing the poet's mood and training, with "Jordan" (I) debating the poetic style. See also Wilcox's treatment, 198.

${ }^{111}$ Blaise does something similar but argues for a Laudian-leaning use of tradition, 1: "The purpose of my discussion is not to defend the idea of a typically Laudian understanding of the Church in The Temple and to deny the importance of Calvinist doctrine in Herbert's conception of theology, but rather to show that his knowledge of patristics prior to the Reformation is the grounds for an implicit theology of beauty in his poetical work."

112 That the repeated need for restoration comes through the sacrament and is invoked through the recursive cycle of greater and lesser heat plays out in other poems, such as "Love I" $(3,12)$ and both "The Temper" poems. It is not until "Love" (III) that the reciprocal relationship is finally broken, once the soul enters heaven.

${ }^{113}$ See Doerksen, Conforming to Word, 96 on this poem: "any devout Christian, conformist, puritan, or papist - could agree with the thrust of this [positive allusion to Phil 2:10]."

${ }^{114}$ See Wilcox's overview, 197-201.

${ }^{115}$ See Hooker, Lawes, V.XXXVIII, "Of Music with Psalms," especially 160-62: "The Prophet David having therefore singular knowledge not in poetry alone but in music also, judged them both to be things most necessary for the house of God. . . In which considerations the Church of Christ doth likewise at this present day retain it as an ornament to God's service, and an help to our own devotion ... In church music curiosity and ostentation of art . . . such that only pleaseth the ear . . . doth rather blemish and disgrace that we do than add either beauty or furtherance unto it."

${ }^{116}$ See variously Herbert's "Wreath:" "Give me simplicitie" (9); Achinstein, 430, on the puritans seeking "simplicity and immediacy" in Herbert's poems and religious attitudes; Guibbory, "Devotional Poetry," 105, linking Sion to the "Jordan" poems as a journey from an "elaborate form of worship to reformed, simple, heartfelt devotion;" or Guibbory, Ceremony and Community, 62: "For all Herbert's attraction to beauty, "Jordan (II)" is strikingly close to [Peter] Smart in suggesting that the attempt to create a suitably glorious worship inevitably turns to idolatry - a suggestion that distances Herbert significantly from the Laudians."

117 Ancilla Pietatis, 22, cited in Wilcox, 368.

${ }^{118}$ All three of these poems are in close proximity, with "Prayer" (II) following "Jordan" (II) and "Sion" appearing three poems later.

${ }^{119}$ Wilcox, 614, cites five references to the phrase in Psalms and two in Isaiah and Hosea.

${ }^{120}$ Regarding sweetness, this poem may speak to "Affliction" (I)'s pleasure and delight.

${ }^{121}$ Sara William Hanley, "Temples in The Temple: George Herbert's Study of the Church," Studies in English Literature, 1500-1900 8.1 (1968): 123. Hanley's is perhaps the seminal work 
on the church sequence. Like Bowers (and myself), she identifies multiple sequences. Her "nature of the church" poems stem from "Mattens" to "Trinity Sunday," which she, 121, subdivides into poems "that exemplify the prayer of the church" and five 'furniture-poems' on the symbol of the church as heart, as building, as body of the faithful, and as the New Jerusalem."

${ }^{122}$ Cf. McLaughlin and Thomas, "Communion," 121, where the church is a house for liturgy. I concur with Van Wengen-Shute, 21: "Superficial evidence of Herbert's preoccupation with the liturgy may be seen even from a cursory glance through the titles of the poems . . . Herbert's debt, however, goes far deeper than these obvious references. The liturgy forms an integral part of his intellectual and emotional make-up, and permeates his whole view of life."

${ }^{123}$ Hodgkins, "Church Legible," 230.

${ }^{124}$ Fish, 54-5; Whalen, 1288: "This" - referring to Herbert's "poetic descriptions" that border on "Roman Catholic sacramental positions" - "would be keeping with Calvin's point that God uses material means to communicate a more rarefied grace."

${ }^{125}$ It should be noted that "Sunday," "Christmas," and "Lent" fall outside this sequence. Since The Temple begins "during" Holy Week, the latter two poems still flow chronologically within the church year laid out by various poem titles.

${ }^{126}$ Pace Doerksen, Conforming to the Word, 27, who claims that Herbert conforms to the Bible instead of the liturgy, as if he cannot do both. Ryrie, Being Protestant, 322-24, contextualizes the $B C P$ as "propaganda for the Bible" or "a Scripture delivery mechanism."

${ }^{127}$ Wilcox, 212.

${ }^{128}$ Compare the image with that of "The Search" where the speaker shows a dichotomy in gesture, where humility is earthbound while looking upon Christ is heavenly: "My knees pierce th' earth, mine eies the skie" (5).

${ }^{129}$ Wilcox, 232, cites Anthony Low, Love's Architecture: Devotional Modes in SeventeenthCentury English Poetry (New York: New York University Press, 1978): 87-8.

${ }^{130}$ Wilcox, 213, cites Sidney Gottlieb, "The Social and Political Backgrounds of George Herbert's Poetry," in Summers and Pebworth, 'The Muses Common-Weale': Poetry and Politics in the Seventeenth Century (Columbia, MO: UM Press, 1988): 115.

${ }^{131}$ McCullough, ed. Selected Sermons, 433: "For Andrewes, Whitsunday was the culmination of the church's liturgical year." See, e.g., his 1606 Whitsunday sermon, XCVI 596: "Howsoever we make it, sure it is that all the rest, all the feasts hitherto in the return of the year from His Incarnation to the very last of His Ascension, though all of them be great and worthy of all honour in themselves, yet to us they are as nothing, any of them or all of them, even all the feasts in the Calendar, without this day, the feast which now we hold holy to the sending of the Holy Ghost."

${ }^{132}$ Bruce Demarest, The Cross and Salvation: The Doctrine of Salvation (Wheaton, IL: Crossway, 1996; 2006 ebook edition), 293: "Regeneration is that work of the Spirit at conversion that renews the heart and life (the inner self), thus restoring the person's intellectual, volitional, moral, emotional, and relational capacities, to know, love, and serve God. . . it is the making alive of what was dead." Furthermore, Wikipedia suggests that for Lutherans and Catholics, regeneration occurs at baptism, whereas Calvinism and Arminian theology suggest regeneration follows baptism, whether in an attempt to overcome depravity or offered through the prevenient grace of Christ's sacrifice. https://en.wikipedia.org/wiki/Regeneration (theology) (accessed July $6,2020)$.

${ }^{133}$ Hanley, 123, argues the church is the "source of grace."

${ }^{134}$ The titles Matins and Even-song seem to be interchangeable with Morning and Evening Prayer, but the connotations must have varied. Only the 1549 BCP retained Matins and Evensong, whereas all later editions, starting in 1552, replaced them with Morning and Evening Prayer. Elizabeth's 1559 Act of Uniformity calls the services Matins and Even-songs, even though it authorizes the $1552 B C P$. The $O E D$ has a number of concordances for the terms, though the presence of matins monger and matins mumbling suggests some level of distaste for the 
ceremonial aspects of the services. "matins, n.”. OED Online. June 2020. Oxford University Press.

1351604 BCP, sig. A1r. Wilcox, 225-7, cites Psalms 8, 51, and 95 as being central to the poem. The latter two feature prominently in the Morning Prayer in the Sentences and the Venite.

${ }^{136}$ Wilcox, 227, cites Cosin's Private Devotions, 80, and St. Basil who says when the day begins the Christian should already be at prayer.

${ }^{137}$ Because I draw heavily from her annotations, I will note that Wilcox does not cite any of these verses.

${ }^{138}$ Wilcox, 227-8. Psalm 95:4-5 is in line 15 (creation of heaven and earth from "In [God's] hands are all the corners of the earth ... he made it") and Psalm 95:6 (featured so prominently above) from "work and workman" from "the Lord our Maker." She cites Noel Kinnamon, "Notes on the Psalms in Herbert's The Temple" George Herbert Journal 4.1 (1980): 10-29.

$1391604 B C P$, sig. A8r.

${ }^{140} 1604 B C P$, sig. A7v, which is from Luke 2:29. Wilcox, 233 suggests the parable of the talents in Matthew 25:21 ("Well done thy good and faithful servant"), though I think John 14:8-10 also seems relevant with Philip asking "Lord, shew us the Father and it sufficeth us" to which Jesus rebukes him, "but the Father that dwelleth in me, he doeth the works." She later, 234, annotating "I rest," cites Matthew 11:28, "Come unto me, all ye that labour and are heavy laden, and I will give you rest" which seems relevant.

${ }^{141}$ Wilcox, 234, cites Cosin's Private Devotions, 141, on praying thanksgiving in the evening where night provides rest from daily labors. She also cites Hanley, who contrasts "rest" with "climbe" and "live" of "Mattens" and "Sinne" (II).

${ }^{142}$ See Priest to the Temple, ch. X, 42, "Even the wals are not idle, but something is written, or painted there, which may excite the reader to a thought of piety" or ch. XIII, 58, with the "all the painting be grave, and reverent" having instructional value. (XIII, 57, also says "that the Church be swept, and kept cleane without dust, or Cobwebs" - which is not the case in these poems). See also Bienz, "Images," 88: "For Herbert the problem posed by images and ceremonial to a biblical faith was less a doctrinal than a pedagogical or a rhetorical problem; and his solution was a rhetorical one."

${ }^{143}$ While some scholars admit that the meditation occurs during the prayer, no one that I have seen comments on the fact that the speaker is not devoting their entire attention to their prayers. ${ }^{144}$ Wilcox, 236.

${ }^{145}$ Wilcox, 236, OED 2 is returns. She offers mend as a pun.

${ }^{146}$ Wilcox, 237. She also cites Vickers who identifies auxesis in which the words are arranged in ascending order of importance.

147 "Businesse," lines 37-8: "Who in heart not ever kneels, / Neither sinne nor Saviour feels." Herbert, as always, is about the submission of the heart. To take this as a defense of kneeling resembles Buckeridge, where the heart must kneel before the body's gesture can mean anything. 148 Wilcox 237, cites Summers, George Herbert: His Religion \& Art (London: Chatto and Windus, 1954; NY: Center for Medieval and Early Renaissance Studies, 1981), 131. Time is also a prominent feature of the preceding "Even-song."

${ }^{149}$ Wilcox, 240. Her citation of Hooker is Lawes V.XXXVI.1.

${ }^{150}$ See Wilcox's overview, 246. In "Love-joy" the stained glass anneals the letters $J$ and $C$ into grapes, which represent joy and charity and Jesus Christ.

${ }^{151}$ Wilcox, 247, citing $O E D 1$.

${ }^{152}$ Cf. Strier, "George Herbert and Ironic Ekphrasis," Classical Philology 102.1 (2007): 101-2, who takes place "as a word that we should clearly take in its social rather than its spatial sense." ${ }^{153} \mathrm{Cf}$. Fish, 45, where man is simultaneously the brittle crazie glasse and the glorious transcendent place, or 54, where Herbert's Temple is building up the temple inside man, where man is the dwelling place of God.

${ }^{154}$ Wilcox, 248. 
${ }^{155}$ Wilcox, 248, notes the Collect and Readings for Trinity being a source for the poem's Trinitarian undergirding. The Williams MS version seems more Trinitarian and credal, gathering nature, grace, and glory together to "attaine thy face" (6), but also shows sin falling from heaven through earth to hell, and then ends with a trinity of God with his saints and angels.

${ }^{156}$ Wilcox, 249, citing Mark Taylor, The Soul in Paraphrase: George Herbert's Poetics (The Hague: Mouton, 1974), 67, though the traditional order would be rise, run, rest, rather than the redemptive pattern Herbert uses.

${ }^{157}$ Van Wengen-Shute, 137. This is not to say that Herbert quits citing the $B C P$, but that the parallels to the liturgical year are less prominent. Another factor to the lack of sequences might be that the 75 poems between "Conscience" and "A Parodie" are not in the Williams MS. See also Fish, 103, whose three steps of catechistical instruction begin with the liturgical before progressing to stational and educational. His metaphor, however, is not confined to The Church. ${ }^{158}$ The actual order of the poems discussed here is: "Jordan" (II), "Prayer" (II), "Conscience," "Sion," "Home," and "The British Church." Cf. Guibbory, Ceremony, 59, where the "The paired poems, 'Sion' and 'The British Church,' most explicitly define the contradictory attitudes toward worship that characterized the early Stuart English church and that shape The Temple, with its concern with form and ritual, one the one hand, and its radical privileging of the heart and spirit, on the other."

${ }^{159}$ For an overview of criticism, see Wilcox, 378. On 380, she draws attention to noted puritan dislike of church music. See also "The Familie," in which Herbert calls for the Lord to "turn out these wranglers, which defile they seat" (7). The poem privileges the decorum of the church: "For where thou dwellest all is neat. . . Order plaies the soul; / And giving all things their set forms and hours, / Makes of wild woods sweet walks and bowres" $(8,11-12)$.

${ }^{160}$ See Wilcox's overview, 381.

${ }^{161}$ Cf. Hodgkins's reading in "'Betwixt This World and That of Grace': George Herbert and the Church in Society," Studies in Philology 87.4 (1990): 463, which argues that Herbert's Tudor church views, privilege of the pastoral over the liturgical (in The Country Parson) mark him as anti-Laudian. To reiterate a point, Laudian views of ceremony do not preclude an emphasis on the heart (they emphasize it). There is no contradiction between a promotion of Laudian ceremony relegated to its decent and orderly place - and Chauncey Wood's assessment in "Solomon's Temple, 'The British Church,' and the Central Role of the Heart in The Temple," George Herbert Journal 35.1/2 (Fall 2011/Spring 2012). See 131, "The contrast between the restrained ornamentation and ritual of the British church and the overdressed Temple of Solomon and the underdressed Puritan church is important, but the real contrast is between the privileged heart and churches of any kind," and 134: "We have a little group of poems: 'Sion' and 'The British Church,' about church ornamentation, and one in between them, 'Home,' about hearts and heaven. What is said in 'The British Church' deals with proper ornamentation, to be sure; what is left unsaid is Herbert's extraordinary privileging of the heart. In fact, beneath the issue of church ornamentation Herbert suggests the even more radical issue of the ultimate importance of the struggles of the heart for individual salvation, which supersede any kind of church."

${ }^{162}$ Wilcox, 384, notes the Bodleian MS's spelling of "seeers" which emphasizes those who see, whereas The Temple has seers, which allows for a pun on prophets. See also Strier, Love Known, 180, who comments that the "artistic transaction described is directed at the art of the temple, not at the object of the art" and compares it to anti-Catholicism.

${ }^{163}$ See for instance, Hodgkins, "Church Legible" 237; Dyck, 548 on the "conclusively iconoclastic impulses" of this poem; and Guibbory, Ceremony, 56, "If 'The British Church' defends the traditional ceremonies of the Church of England, 'Sion' presents an explicitly anticeremonial position' or her "Devotional Poetry," 105, with Herbert "sharply departing from Hooker" about whether architecture pleases God. To the last point, see Hooker, Lawes V.XLVIII.2.201: "Every good and holy desire though it lack the form, hath notwithstanding in itself the substance and with him the force of a prayer, who regardeth the very moanings, groans, 
and sighs of the heart of man. . . We thereby declare unto God what our own desire is that he by his power should effect." Hooker speaks of the power of prayer, which Herbert here echoes. As with the temple, Hooker would agree it is not the form that imbues it with power or pleasantness, but the intention of those who use it. Herbert dismisses here the valuation of the temple for the temple itself.

${ }^{164}$ Another poetic parallel is "Affliction" (III): The heart "did heave" an "O God!" (1), resulting in "A gale to bring me sooner to my blisse" (12).

${ }^{165}$ In the Andrewesian "Beauty of Holiness" the sumptuousness of the temple reflects God's presence in it; "Sion" does not address God's presence, but the following poem "Home" does, with its pleas for God to be present for the Speaker.

${ }^{166}$ One of the others being "Lent," a polemically charged poem about following worship practices instituted by the church. Herbert's position resembles Featley's, though comparisons to Andrewes and Cosin can be made. See Hampton, "Welcome Dear Feast," passim.

${ }^{167}$ See Wilcox, 390. Doerksen sees it as inclusive; Strier reads it attacking Catholicism; Summers and Pebworth suggest it even-handedly critiques both Catholicism and Genevan Calvinism. Hodgkins places "The British Church" "exactly midway in the lyrics of "The Church"” and finds the Anglican "fit array' concordant with the spiritual "fabric within" of "Sion." Wilcox also cites the influence of Hooker's via media and Spenser's Medina, the golden mean in, who is described as "sober," "rich arayd, and yet in modest guize, / In goodly garments that her well became," without vanity but with gravity, "sober grace, and goodly carriage: / With equal measure she did moderate / The strong extremities of their outrage ... So kept she them in order, and her selfe in heed."

${ }^{168}$ Ceremony and Community, 51.

${ }^{169}$ Wilcox, 392, citing chapter 13 of Country Parson. She leaves out the preceding line, Priest to the Temple, 58-9, about the "fitting, and sightly Communion Cloth" done "not as out of necessity, or as putting a holiness in the things." As Andrewes preached in 1617, it is not that the temple should be holy itself, but that there be holiness in the temple.

170 "Church-rents and schism" also concerns the "Mother" church, but, begging the question that there is a difference, Herbert makes no attempt to differentiate whether the church between the British church and the universal church.

${ }^{171}$ Wilcox, 623, cites Stanley Stewart, George Herbert (Boston: Twayne Publishers, 1986): 105.

${ }^{172}$ Wilcox, 623-5, provides a succinct summary. She begins, 623, with Booty's comments on the "rarely celebrated and poorly attended" sacrament that suggests the poem "was thus no doubt inspired by H[erbert]'s practical experience as a priest," which then suggests a certain sacerdotalism. She cites Veith (himself a Lutheran) with his comments on the "clear and unambiguous" Lutheran stance on the "efficacy of the bread and wine," while Benet suggests a "more Protestant" (read: Calvinist) take on mending and weeping in a repentant state. Hunter offers a quotation of the Institutes that suggests all are invited, but only the faithful can receive it; Strier echoes this saying that the "Protestant tradition is to "call "all" to God' but not 'invite all to the Eucharist." Herbert does not make such a distinction, though "Lord I have invited all, / And I shall / Still invite, still call to thee" (31-33), suggests that he calls all to both the Sacrament and to God.

${ }^{173}$ Openness to partake in the sacrament was not uniform across all Protestants. Arnold Hunt, “The Lord's Supper in Early Modern England," Past \& Present, 161 (1998): 75, comments on the difference between Tymme (with whom Herbert seems to be closer) and Bayly: "While Tymme [in Silver Watch-bell] invited everyone to communion as long as they repented of their sins, Bayly was, in effect, advising people to withhold themselves from the sacramentif they were unable to satisfy this far more stringent set of conditions."

${ }^{174}$ Wilcox, 625, cites Matthius Bauer, “"A Title Strange, Yet True': Toward an Explanation of Herbert's Titles" in George Herbert: Sacred and Profane, edited by Wilcox and Todd, (Amsterdam: Free University Press, 1995), 110. 
${ }^{175}$ Wilcox, 627.

${ }^{176}$ Cf. Ephesians 4:4-6 (KJV): "There is one body, and one Spirit, even as ye are called in one hope of your calling; One lord, one faith, one baptism, One God and Father of all, who is above all, and through all, and in you all." Biblehub connects this to Psalm 133:1 - "Behold, how good and how pleasant it is for brethren to dwell together in unity!" and 1 Corinthians 1:10 "Now I beseech you brethren, by the name of our Lord Jesus Christ . . . that there be no divisions among you; but that ye be perfectly joined together in the same mind and in the same judgment" which also warns against contentions within the church.

${ }^{177}$ Wilcox, 627, notes that the meter (lines of 7-3-7-7-4-7 syllables, AABCCB) "appears to derive from the Sidney translation of Psalms 38." The Psalm (Domine, ne in furore) touches on several similar themes, especially the last two verses (21-22) which Sidney renders as "Do not, Lord, then, me forsake / Doe not take / Thy deere presence farre from me, / Haste, O Lord, that I be staid / By thy aid, / My salvation is in thee" (61-66). Text from The Psalms of Sir Philip Sidney and the Countess of Pembroke, ed. J.C.A Rathmell, (New York: Anchor Books, 1963). Digitized by the Internet Archive. Both "The Banquet" and the following "A Parodie" share themes lamenting the possibility of God's absence from the speaker.

${ }^{178}$ Wilcox, 629. She also cites Ephesians 3:19 - "to know the love of Christ, which passeth knowledge." 1604 BCP, sig. N4r.

${ }^{179}$ Wilcox, 630, offers three groupings of three within meet my taste: meet as meaning come face to face with, satisfy, pay in full; taste being the sensual experience of Christ in the elements, preference of Christ being everything, and the spiritual condition; both of which work together for "three main emphases" of the sensual aspect of the Eucharist, spiritual satisfaction, and recognition of Christ's prevenient sacrifice.

${ }^{180}$ As such, though the rhyme is sing instead of sting, the opening recalls 1 Corinthians 15:55, 57: "O death where is thy sting? O grave, where is thy victory? ... But thanks be to God, which giveth us the victory through our Lord Jesus Christ." Wilcox, 649, cites 15:52 “. . f for the trumpet sall sound, and the dead shall be raised incorruptible, and we shall be changed" after the beauty-clad bones in line 20, as a response to the dry bones in Ezekiel.

${ }^{181}$ Wilcox, 652; she notes that music was assumed to be the cure for being bitten by a tarantula. 182 The third section, The Church Militant has two more poems and a second Finis. Aside from placing a liturgical song in a prominent place of The Temple, Herbert's use of the Gloria at the end has strong Hookerian echoes. See both Lawes, V.LXXXI.11.406: "this in effect is the very song that all Christians feasts do apply as their several occasions require" which marks it as timeless and XLII.7.182: "Touching the Hymn of Glory, our usual conclusion to Psalms . . if that joyful Hymn of Glory have any use in the Church of God whose name we therewith extol and magnify, can we place it more fitly than where it now serveth as a close or conclusion to psalms?" While neither "Love" (III) nor The Church are themselves Psalms, the devotional aspect of Herbert's lyrics is similar and the ethos of the Gloria likewise applies.

${ }^{183}$ Moreover, Wilcox, 658, notes that the poem draws heavily on the "Exhortation to the Lord's Supper" (in attendance and proper preparation) and the "Prayer of Humble Access" (in which divine mercy grants communicants hope of worthiness) in the $B C P$ 's communion service. Her overview, 658-9, contains scholarly interpretations that the poem is about heaven, the heavenly feast, the earthly Eucharist, and God's charitable agape love focused on man. McLaughlin and Thomas, 111, read "Love" (III) as the priest's exhortation to sinners.

${ }^{184}$ On this duty, see Andrewes's 1617 Gunpowder Plot sermon in Chapter One.

${ }^{185}$ Wilcox 659. Strier, Love Known, 78-9, draws attention to the "host-Host" pun and argues "The poem is about agape" (more so than the Eucharist). Guibbory, Ceremony, 77 expresses my views as well: This poem "could be appreciated by ceremonialist and puritan alike ... [and] is the culmination of The Temple's attention to ritual. Yet the plainness and simplicity . . could appeal to puritans. . [Sitting] assumes the posture puritans preferred at Communion, avoiding the gesture of kneeling that was a sharp point of contention. But, as the poem describes the ultimate 
communion in heaven, Herbert may imply that only in heaven (not on earth, in the church) is the egalitarian posture of sitting appropriate. . . Herbert thus allows readers of different ideological bents to find his poetry expressive of their view of worship. Doerksen, Conforming to the Word, 100, suggests Andrewes's would be outraged by Herbert's familiarity and the last line would "have been the last straw," but does not distinguish between an earthly or heavenly communion. Cf. Hodgkins, "Church Legible," 239: "The communion of 'Love' (III), like the entire 'mystical repast' of 'The Church,' cannot refer to the literal sacrament ordered by the Prayer Book, for if it did, Herbert would never 'sit and eat' (emphasis mine). In The Country Parson he rejects such a Eucharistic posture ... Ironically, it is because of Herbert's known loyalty to the Church of England's external forms that 'Love' (III), like the whole of The Temple, must refer to the Christian's internal, eternal fellowship with the risen Christ."

186 This liturgical act is repeated through "L'envoy" and the trinitarian doxology that ends The Church Militant. Stephenie Yearwood, "The Rhetoric in The Temple," Studies in English Literature, 1500-1900 23.1 (1983): 143-44, comments that the doxology is "a communal prayer, one which we are all invited to speak." It would be tempting to see "The Church Militant" as a Laudian expression of the universal church, but Laudians do not have exclusive claim to that lineage - they just claim it more strongly than Calvinists. Many scholars cite the lines about the American strand (235) as being the source of contention for the Laudian censors; see, for instance, Wilcox, 683-4, or Doerksen, Picturing Religious Experience: George Herbert, Calvin, and the Scriptures (Newark: University of Delaware Press, 2011), 43. 
Conclusion: The "Manifold Inconveniences" of Laudianism

"But if these accounts of the Jacobean bishops were only half true, then Archbishop Laud was indeed the greatest calamity ever visited upon the English Church."

To take Collinson's conditional at face value, it was Laud who exaggerated the divide between puritans and the orthodox English Church, which resulted in religious schism and the English Civil War. ${ }^{2}$ This dissertation has attempted to challenge this truism of Laudianism, fueled more by the influence of Civil War polemics than Laud's own writings and the assumption that his churchmanship was aggressively radical, egregiously innovative, and inimical to any strand of Calvinism, not just puritanism. ${ }^{3}$ While the state church under Laud and Charles did enact punitive measures for nonconformity, the anti-puritanism has roots in James's reign (if not earlier) as do many of their policies. If we recognize the lineage to which Laudianism ascribed, we can diminish the claims of innovation. One of the more prominent examples of this, especially as reiterated by the Avant-Garde Conformity of Hooker and Andrewes, is Cranmer's methodology in revising the English prayerbook, relying on scriptural authority and the Ancient Church tradition to promote a Pauline sense of decent and ordered worship. Although it is true that many of the prominent Laudian voices belonged to bishops, even non-episcopal ministers preached and wrote for conformity in this vein, as seen in all but Chapter One. While the Calvinist and anti-Calvinist dichotomy becomes starker in the years leading up to the English Civil War, the doctrinal and theological positions of the Laudians still resembled those earlier ceremonial positions. These arguments, for the most part, did not seek to ouster Calvin's influence altogether, but do away the elements brought in by second- and third- generation Calvinists. ${ }^{4}$ As shown in the Introduction, 
even Calvin supported moderate ceremony. This dissertation has privileged Laudian voices in an effort to take what they say seriously and not merely as anti-Calvinist propaganda. At the same time, it has sought to avoid the anachronistic tinge characteristic of the Victorian scholarship that tried to position the English Chuch as a via media through reading avant la lettre Anglicanism in these early seventeenth-century divines.

By disregarding the prevalence of this binary and stereotypical portraits of the state of the English Church, this project has given more room to see the variety of beliefs promulgated by religious writers in this period. This has played out in two facets, in the content and the genres of the texts considered. Chapter One challenged the equivocal tendency to treat court sermons as theological tracts. Through examining the hortatory elements of Andrewes's and Buckeridge's sermons, we saw that while both preachers were responding to political events, they framed issues of gesture to show the mutual relationship between internal and external elements of piety in outward acts of physical worship. Chapter Two juxtaposed two different private devotionals that ultimately urged conformity to Church practices and revealed the puritan polemics that attacked Cosin relied on a deliberate misreading and misrepresentation of his text. Chapter Three turned to authors not commonly considered Laudian (many of whom were deemed at one point to be "anti-Laudian") to show how the "elite matter" of bishops was presented to common households. With George Herbert, Chapter Four again turned to a non-bishop (but court-adjacent) preacher whose poetry demonstrates the fluidity of religious ideas and the potential fallacy in maintaining strict doctrinal allegiances and prescriptions. In all of these, issues of the centrality of gesture, the sacraments, sermons, humility, and 
presumption were present, and the positions of conformity rarely seemed to be extreme or outside of the mainstream.

In the space that remains, I want to address the specter that has loomed over this entire project, the viewpoints of Laud himself. I have, for the most part, avoided Laud's works for a few reasons. One was for the sake of chronology, to showcase the voices that may have influenced a younger Laud, to maintain that the underpinning ideas of Laudianism did not develop in a vacuum, and to demonstrate that Laudianism was not wholly dependent on Laud himself. While any periodization has its shortcomings, the 1633 cutoff also tried to separate the early forms of Laudianism from the more polarizing forms that materialized in the post-Laud era of the Civil War and Interregnum. On the other hand, Laud's writings show both the continuities and discontinuities throughout his career, which, in his own words, was marked by puritan libels of innovation. This brief survey (pace Prynne) of selective works overlaps with most of the genres found in the preceding chapters, excepting poetry, and ends with a juxtaposition of Laud's death (January 1645) to Parliament's authorization of the Directory of Public Worship. The lengthy quotations from these works align with many of the approaches and keywords seen in preceding chapters. Much of the Laudian legacy, as it were, found in later authors has been relegated to the endnotes. ${ }^{5}$ What we will see in these excerpts is Laud refusing to let his detractors define his beliefs or religious sympathies, remaining adamantly Protestant unto his dying breath, and insisting that his "innovations" were simply the preservation of Reformation traditions. Acknowledging Laud's self-identity is critical to the understanding of Laudianism because, as John Reeks has articulated, "the 
gravitational pull of Prynne's narrative pervades more recent scholarship" and undermines the effort to understand Laudianism in its own terms. ${ }^{6}$

While Bishop of St. David's (1621-26), Laud preached in a manner that resembled Buckeridge, his Oxford tutor, in form and content. In two elite-facing sermons, Laud argued that the inward acts of religion make it worthwhile and joyful, which may (or may not!) manifest in external forms. In a 1621 sermon on James's inauguration, Laud preached trickle-down joy, where the divine blessings of the king were passed onto the people through the practice of true religion. Unlike in the sermons of Buckeridge and Andrewes where the internal and external coexist without a clear delineation of which occurs first, Laud's joy originates with the internal: "if the King will looke to the [sic] presevation of his owne joy, he must seeke it where these cannot hinder it, at $T u$ laetificasti, Thou Lord hast joy'd him. And the word in my Text is $\chi \alpha \rho \alpha$ [chara], which signifies a joy that is inward, and referred to the mind. . . Let the Intentions be right and honourable, and joy will follow them." ${ }^{.7}$ This joy manifests itself through what, later in the decade, Cosin would describe as "The three Theologicall Virtues" of faith, hope, and charity. ${ }^{8}$ The following quotation would not seem out of place in the start of Buckeridge's 1618 Passion Sunday sermon, where true religion, the inward worship of the heart, follows the king's example:

And since we have found Faith and Hope in this action of Trusting God (as our English well expresses it) let us never seeke to shut out Charitie; And if Faith, Hope, and Charity bee together, as they love to goe, then you may understand the Text, Quia Sperat, because he Hopes, de toto cultu, of the entire worship of God. For (as S. Isidor observes) in all inward worship, which is the heart of Religion, are these three, Faith, Hope, and Charity. And in the most usuall phrase of Scripture, (though not ever) scarce one of these is named, but all are understood to be present; and if so, then, because he trusts, is as much as Quia colit, because he worships. . . It is in the Text then, that a Kings Religion is a great cause of his happinesse. The greatest Politicians that are, have confessed thus farre, that 
some Religion is necessary, to make a King a Blessing to his People, and a Common-wealth happy: But the matter is not great with them, whether it be a true, or a false Religion, so it be one. But they are here in a miserable errour; for since they suppose a Religion necessary (as they must) my Text will turne all the rest upon them; that true Religion is most apt, and most able, to Blesse and Honour both King and People. (77-78)

The important element of this passage is the interplay between (true) religion and worship - "true Religion breeds true Faith" (78). In order for Christians to receive blessings, they have to worship God, which stems from internalized religious attitudes. Another element this passage highlights is the interplay between church and state. One can hardly see a mention to Laudianism without seeing a rigid church-state structure, so seeing a somewhat typical expression of the king's role in the religion of his people, shows that, if Laud were ever corrupted by power, his pre-ascendant preachings were not highly innovative. ${ }^{9}$

Lest Laud's 1621 sermon seem too far afield of the discussions of internal and external worship seen in this project, his 1625 sermon on the opening of Parliament turns to the role of ceremony. With its explicit mention of the liturgy and worship in the temple and the role of the state in comparison to the church, the sermon better sets up some of the motifs that become turbulent in subsequent decades. ${ }^{10}$ Laud speaks in language reminiscent of Cranmer's $B C P$ essay on ceremony, which affirms the tradition of the church and the sacrificial nature attached to ceremonies. This passage also speaks to the concerns Prynne and Burton raise against “Judaizing” ceremonies present in Cosin's Collection of Private Devotions and the elevation of the name of the Lord (Cosin's defense for including the $I H S$ in his frontispiece):

Therefore assembling and meeting at publike service in the Church is no humane Institution, but from God himselfe. Nor is this Ceremony Jewish or Ambulatory, to cease with the Law, and that Temple; but omnino perpetuum, altogether 
permanent in the Church of Christ, Christians must to the Church and place of service too...

The 70. and the Vulgar have it, To confesse to the name of the Lord. It comes all to one. For be the word Thanke or Confesse, it stands here expressive of the whole Liturgie, of all the publike externall Service of God: All which if it be not accompanyed with the inward service of the heart, is worth nothing. So they went to the Temple, as we must goe to the Church, to confesse, to pray, to worship, to praise, to give thanks to God, which even under the Law was preferred before Sacrifice it selfe, Psal. 50. (111-12, underline added for emphasis)

While later opponents of religious ceremony attack it for external superstition, Laud privileges that worship begins with the heart (yet another echo of Buckeridge's sermondefense of kneeling). Moreover, though the liturgy represents external service and is communal in nature, that communion depends upon the state of each participating individual. This has been a through-line in arguments against profaning the temple through hypocritical acts of service, as demonstrated in Chapter Three. The external without the internal is empty and worthless; the outward is the physical manifestation of the joy and grace of the Christian in their worship of a deity who offers them salvation. The actions Laud promotes here are not inherently gestural but the result of the service whether through sermon hearing or service participation. ${ }^{11}$

Proceeding to 1637, four years into Laud's tenure as Archbishop, the Laudian "beauty of holiness" campaign was starting, with the promotion of external rites and the altar rail extending to non-cathedral churches (the latter of which was seemingly enforced through "fair persuasions" and visitation articles, rather than legislative force). ${ }^{12}$ In June, Laud delivered a speech to the Star Chamber, which was later published by Richard Badger, responding to the censure of (John) Bastwick, Burton, and Prynne. ${ }^{13}$ While Laud seeks to dismiss Burton and Prynne as odious and seditious libelers (2, 5, 9, inter alia), his defense rests upon familiar argumentative lines: that the ceremonial lineage is 
consistent with the reformed and true church, that worship is done to God, that sermons are only a part of worship, and that ceremonial practices are an indifferent topic. The printing of this speech perhaps inverts the polemical situation of Chapter Two in that he publicly responds to the critiques of his work. Laud sums the critiques as such: "For my care of this Church, the reducing of it into Order, the upholding of the Externall Worship of God in it, and the setling of it to the Rules of its first Reformation, are the causes (and the sole causes, what ever are pretended) of all this malicious storme, which hath lowred so black upon Me \& some of my Brethren" (4-5). Although Laud frames his position with almost Cranmerian terms, the moderation gives way to tinges of blatant anti-Calvinism, where he condemns lay consistories, "Calvins new-fangled device at Geneva," as an assault on iure divino episcopacy (7). Laud rejects the premise that "the externall decent worship of God" is inherently Romish superstition, which assumes that decent worship cannot happen without popery (11-12). Perhaps the most interesting development in this speech is the development of the debate over sermon-centered piety. While the Project Canterbury gloss that the "central portion is a justification of . . the superiority of the Eucharist over the sermon" is misleading at best, Laud does diminish the sermon's role in the beauty of holiness. ${ }^{14}$

This diminution occurs chiefly in two sections of his speech. First, responding to Prynne's anti-prelatical Newes from Ipswich, Laud rebuts the premise "Whereas Sermons are the onely meanes to humble men" (17). ${ }^{15}$ In his rebuttal, Laud does not offer an alternative source for humility and instead attacks Henry Burton's recently published sermons. ${ }^{16}$ Here, Laud does not juxtapose sermons to the sacrament, preferring instead to 
offer only a slight concession for their edifying value and suggest that there are times to avoid them altogether:

Nor Thirdly is that true, that Sermons are the Onely meanes to humble men. For though the preaching of Gods word, where it is performed according to his Ordinance, be a great meanes of many good effects in the soules of men; Yet no Sermons are the only meanes to humble Men. And some of their Sermons are fitter a great deale for other operations: Namely, to stirre up sedition, as you may see by Mr. Burtons; for this his printed Libel was a Sermon first, and a Libel too. And 'tis the best part of a Fast to abstaine from such Sermons. (18)

This rebuttal alludes to what is appropriate during fasting and during times of plague. The puritan attack against ceremonies suggests that they are profane, external acts without much humility. While Laud stays consistent with the blending of piety of body and soul "For my owne part I take my selfe bound to worship with body, as well as in Soule, when ever I come where GOD is worshipped" (46) - the external is amplified when in God's presence. It is in this later, second section, that an argument for Eucharistic real presence seems likely. Laud conflates the beauty of holiness with the debate of centering piety around sermons, echoing the prescriptions for reverence and holiness inside the church and at communion, seen earlier in Chapters One and Three:

And you my Honourable Lords of the Garter, in your great Solemnities, you doe your Reverence, and to Almighty God, I doubt not, but yet it is Versus Altare, towards his Altar, as the greatest place of Gods Residence upon earth. (I say the greatest, yea greater then the Pulpit. For there 'tis Hoc est corpus meum, This is my Body. But in the Pulpit, tis at most, but; Hoc est Verbum meum, This is my Word. And a greater Reverence (no doubt) is due to the Body, then to the Word of our Lord. And so, in Relation, answerably to the Throne, where his Body is usually present, then to the Seate, whence His Word useth to be Proclaimed. . . And this Reverence yee doe when ye enter the Chappel, and when you approach nearer to offer. And this is no Innovation, for you are bound to it by your Order, and that's not New. And Idolatry it is not, to worship GOD towards His Holy Table. (47-8) ${ }^{17}$

The beauty of holiness, when regarding the use of the altar, emphasizes God's presence in the sacrament, which can serve to privilege the altar over the pulpit. Laud makes this 
elevation more prominent and explicit than Andrewes did in his 1617 Gunpowder sermon. This elevation, however, does not diminish the sermon to nothing. While ordinances may have forbidden sermons for reasons of public health, such measures were not permanent. ${ }^{18}$ Given the polemical urge to distort, it is easy to see how Laud's view can be stretched to mean that the sermon and sacrament are not complementary. ${ }^{19}$ Laud's speech did have some effect as, instead of receiving punishment himself, Burton, Prynne, and Bastwick were censured. This reprieve would be temporary, however, and Laud himself would end up imprisoned before his execution.

It was during his imprisonment, in 1644, that Parliament authorized the Directory for the Publique Worship of God and outlawed the use of the $B C P .{ }^{20}$ In many ways, the Directory serves as an anti-Laudian monument. The Directory codified the puritan complaints against the chief elements of Laudian conformity by prohibiting the offending elements of worship, those "manifold Inconveniences that have arisen by the Book of Common-Prayer" that allegedly have no scriptural warrant (n.p.): the set prayers of the liturgy, vanity of superstitious ceremonies, and festival days. ${ }^{21}$ While the Directory would be temporary, with the $B C P$ being reinstituted after the Restoration (Cosin playing a key role in the 1662 revision), the complaints it expresses were longstanding and doubtlessly amplified by the publication of the 1637 Scottish $B C P .{ }^{22}$ Whereas the charges against Laud were for innovation, the Directory argues that it was Cranmer and his associates who did not do enough to conform to the Reformed tradition, which kept the English Church largely compliant with Rome. ${ }^{23}$ The lengthy quotation that follows shows the juxtaposition of attitudes, which is important to consider in terms of the responses that would be published to it. This excerpt summarizes the puritan complaint against the 
use of liturgy and its apparent damage to the church's health due to its exclusive

promotion:

Howbeit, long and sad Experience hath made it manifest, That the Leiturgie used in the Church of England, (notwithstanding all the pains and Religious intentions of the Compilers of it) hath proved an offence, not only to many of the Godly at home; but also to the Reformed Churches abroad. For, not to speak of urging the Reading of all the Prayers, which very greatly increased the burden of it; the many unprofitable and burdensome Ceremonies, contained in it, have occasioned much mischief, as well by disquieting the Consciences of many godly Ministers and people who could not yield unto them, as by depriving them of the Ordinances of God, which they might not enjoy without conforming or Subscribing to those Ceremonies. Sundry good Christians have been by means thereof, kept from the Lords Table, and divers able and faithfull Ministers debarred from the exercise of their Ministery (to the endangering of many Thousand Souls, in a time of such scarcity of faithfull Pastors) and spoiled of their livelyhood, to the undoing of them and their Families. Prelates and their Faction have laboured to raise the Estimation of it to such an height, as if there were no other Worship, or way of Worship of God amongst us, but onely the ServiceBook; to the great hinderance of the Preaching of the Word, and (in some places, especially of late) to the justling of it out, as unnecessary; or (at best) as far inferior to the Reading of Common-Prayer, which was made no better then an Idol by many Ignorant and Superstitious People, who pleasing themselves in their presence at that Service, and their Lip-labour in bearing a part in it, have thereby hardened themselves in their ignorance and carelesnesse of saving knowledge and true piety. (2-4)

The Directory specifically targets ceremonial ministers and bishops (prelates) for their promotion of the $B C P$. To elevate preaching, the Directory undersells the scriptural bases of the liturgy. As a whole, the Directory seeks to make the worship service grave and somber. Where, from a puritan perspective, the $B C P$ induced vanity - self-serving ceremonies, errant and heartless set forms, undo actions in worship - the Directory sought simple biblical edification. In laying out the subject and method of a sermon (2836) and instructions for the reading of Scripture (not mandating a particular translation, 12), the Directory nonetheless ignored the $B C P$ 's prescriptions that would submit churchgoers to the whole of the Bible in a year of services (with some parts repeated 
multiple times). Instead of set forms for the minister to repeat, the Directory gave a sense of what and whom should be prayed for, and in what order. Perhaps the biggest change is that, while the $B C P$ could be used by priest and parishioner alike, the Directory focused only on the pastor; the duty of the parishioner was to listen and sing Psalms, not repeat versicles and hymns.

I include the above quotation because, aside from the more polemical tracts, it provides the Laudian (or here, proto-Anglican might be proper) base something to unite around and combat. ${ }^{24}$ It also shows the malleable and competed-for identity of the Church of England - it is after the publication of the Directory that several of the authors in Chapter Three ran into legal trouble for their (non)conformity. While later Laudian tracts would defend the Church's Reformed tradition and criticize the puritan views, Laud himself spoke much on the Church's identity. In giving his own funeral sermon, Laud praised the church which "hath flourished and been a shelter to other neighbouring Churches, when stormes have driven on them, but alas, now it is in a storme it self . . that in every cleft prophanenesse and irreligion is creeping in apace . . that Church which all the Jesuites machinations in these parts of Christendome could not ruine, is now fallen into a great deal of danger by her owne." 25 This leads to his reaffirmation of his Protestant identity, stubbornly defiant of the charges of reintroducing Popery to England that lead to his execution on the scaffold:

I was borne and baptized in the bosome of the Church of England, as it stands yet established by Law, in that profession I have ever since lived, and in that profession of the Protestant Religion here established I come now to die: this is no time to dissemble with God, least of all in matter of Religion; and therefore I desire it may be remembred: I have alwayes lived in the Protestant Religion established in England, and in that I come now to die: what Clamors and Slanders I have endured labouring to keep an Uniformity in the external service of God, according to the Doctrine and Discipline of this Church, all men knows, \& I have 
abundantly felt ... and I take it now on my death, that I never endeavoured the subversion of the Laws of the Realme, nor never any change of the Protestant Religion into Popish superstition, and I desire you all to remember this Protest of mine, for my innocency in these, and from all manner of Treasons whatsomever. (8-9)

Even at his death, Laud maintained that the "innovations" he brought into the church were nothing new but uniform with the longstanding tradition of the Church, even if the Directory sought to undo the lineage invoked by Cranmer in the mid-sixteenth century and re-invoked by Hooker and the later Jacobean divines. ${ }^{26}$

This leaves us at a culmination of where this project began, with a distinctly Protestant view of Laudianism. The Laudian-puritan dialectic stems from the domineering presence of the more vociferous critics of Laud being given the most space in press and scholarship - even if recent scholarship has shown the presence of "moderate puritans" that make Prynne and Burton "hardly representative" English puritans. ${ }^{27}$ By unprivileging puritan biases, we can better understand Laudians as they promoted their churchmanship. While the external elements of worship were certainly a Laudian focus, time and time again, they pushed for eloquent and sumptuous worship so that the external could inspire the heartfelt internal piety and reverence (and vice versa), which they felt was what God wanted for his followers. Moreover, these viewpoints were often consistent not only with Reformed and Lutheran practices but with the traditional and ancient church that existed long before the corruption of popery. ${ }^{28}$ Although issues of gesture became bipartisan leading up to the Civil War, early Laudian writers sought not to attack Calvinist beliefs (with exceptions for predestination) but to reform manners for all who worshipped. This push for more reverent behavior, often expressed in didactic modes, resonated in several locations, whether the pulpit at Whitehall, the family 
household, or the private lyric poetry of a retiring country parson. All writers in this project saw themselves as loyal children of the Church of England, the Protestant identity of which was both catholic and Reformed.

One of the undercurrents of this project is that Laudianism was present in multiple genres. Rather than flatten generic differences, this consistency serves to enliven what genres can do. It was the flattening of sermons as dry theological tracts that diminishes the rhetorical nuances of sermons being occasional pieces. ${ }^{29}$ Perhaps the most important broadening concerns private devotionals. While scholars have longed used private devotionals to see how individuals practiced, they have nevertheless been reluctant to use them to engage with the more "serious" theological debates that were seen to be exclusive to the court. As Laudianism is, at its core, concerned with individual practice (in corporate settings), this omission in scholarship has been puzzling. Future enterprise into Laudian devotionals, then, seems to be promising. A broader view of Laudianism also has implications with other poets. While poets like Robert Herrick and Henry Vaughan seem to exemplify the antagonistic strains of Laudianism, understanding Laudianism as not being wholly external or the domain of bishops may alter the way we view Donne, whose later sermons show an evolution toward Arminian thought, or the "young" Milton who may have flirted with Laudianism before renouncing it in the editorial apparatus of his 1645 Poems. ${ }^{30}$ Rather than being the diametric opposite of puritanism (which itself was ununified), Laudian thought encapsulated a wide variety of ceremonial opinions and conformity to the $B C P^{\prime}$ 's liturgy.

${ }^{1}$ Collinson, Religion of Protestants, 90.

${ }^{2}$ Contextually, Collinson's declaration comes at the summation of his argument, 82, that "Calvinism can be regarded as the theological cement of the Jacobean Church." The subsequent overemphasis on Calvinism "may divert attention from the distinctiveness of the churchmanship 
exhibited by those representing 'Calvinist episcopalianism', as well as somewhat falsifying the principles of some ... who believed in theological reconciliation and strove to mediate between the Calvinist and Arminian positions." For Collinson's conceptualization of the Jacobean Church, Laudianism meant that "Orthodox" viewpoints had evolved from Calvinism to Arminianism, and that while puritans were the polemical antithesis to both, Laud's partisanship undid the laissezfaire attitude of his predecessor, Abbott who was more tolerant than Bancroft.

${ }^{3}$ In a review of a recent book on Laud's entanglement in Scotland, Benjamin Guyer calls this an assumption of "the descriptive validity - the fundamental truthfulness - of the claims made by Laud's critics." "Review: 'This Great Firebrand': William Laud and Scotland 1617-1645," Anglican and Episcopal History 88.2 (2019): 210-12, here 211-12.

${ }^{4}$ To a certain extent, the anti-Calvinism of Laud came not in the substance of his churchmanship as in the enforcement of it. See Maltby, 86, on the redefinition of Laudian innovations as differing from Jacobean churchmanship "more in degree than in substance" or Fincham, 262: "After the Restoration, [one biographer suggested] that had the episcopate treated their clergy courteously they might have avoided the misfortunes which befell them in the 1640s. This is clearly an exaggeration, but it does echo Sir Edward Dering's condemnation in 1641, not of Laud's desire for uniformity of public worship, so much as the manner in which he pursued it." The citation of Dering is A Collection of Speeches, (London: 1642), 4: "His intent of publike uniformity was a good purpose, though in the way of his pursuit there of he was extreamely faulty." That the claim of aggressive enforcement might be overstated, see Reeks, passim. ${ }^{5}$ The omission of poems in this chapter stems simply from Laud not writing poems. One need not venture far into the works of Henry Vaughan to see an anti-Calvinist perspective or Robert Herrick for pro-ceremonial views in poetry. Herrick's ceremony in "Mattens, or morning Prayer" in Hesperides (1648) could be construed as the most sympathetically Catholic literature in this dissertation:

When with the Virgin morning thou do'st rise,

Crossing thy selfe; come thus to sacrifice:

First wash thy heart in innocence, then bring

Pure hands, pure habits, pure, pure every thing.

Next to the Altar humbly kneele, and thence,

Give up thy soule in clouds of frankinsence.

Thy golden Censors fil'd with odours sweet,

Shall make thy actions with their ends to meet. (1-8)

Quoted from The Complete Poetry of Robert Herrick, edited by J. Max Patrick, (New York:

W.W. Norton, 1968).

${ }^{6}$ Reeks, "'Fair Persuasions'?," 177. Without saying as much explicitly, Reeks intimates a certain skepticism at this received narrative. His outline, 177-79, of the historiographical debate surrounding Laudianism is excellent. See also McGrath, passim.

${ }^{7}$ Laud, Seven Sermons (London: 1651), 70. This publication collected already published sermons Laud had preached before Parliament or the king, most from the 1620s. This sermon is on Psalm 21:6-7: "For thou hast set him as Blessings for ever: thou hast made him glad with the joy of thy countance. Because the king trusteth in the Lord: and in the mercy of the most High he shall not miscarry." The Greek transliteration comes from Strong's Bible Concordance (https://biblehub.com/greek/5479.htm), which suggests awareness of God's favor through grace and has overtones of sacramental importance, though this is not a sacramental sermon.

${ }^{8}$ Cosin, Private Devotions, sig. C11v.

9 "Somewhat typical," cf. Buckeridge or Donne's inaugural sermon to Charles in 1625 on Psalm 11:3.

${ }^{10}$ This sermon shows Laud's prescience. His sermon-text is Psalm 122:3-5: "Jerusalem is builded as a citie that is at unity in it selfe, (or compacted together.) For thither the Tribes goe up, even the Tribes of the Lord, to the Testimony of Israel, to give thanks unto the Name of the Lord. For 
there are the Seats (or the Thrones) of Judgment; even the Thrones of the house of David." Laud, Seven Sermons, 96, uses typology to show that the state functions for the happiness of its people and the temple for God's service: The temple is "the Type of the Church, that's for God's service. No Temple but of that. The City the Type of the State, that's for the peoples peace. No happy State but in that." Later, 106, he preaches "doctrine and discipline" to coexist in the unity between church and state before concluding, 128-9, with the Jacobean notion of "no bishop, no governor" to warn against lay consistories and overpowered civil courts.

${ }^{11}$ Cf. Herbert's "prayer's the end of preaching." Laud continues with an emphasis on necessary actions, and the appropriateness of blending law and gospel (or ceremonial with the good news), 114-15: "Well then, To pray, To praise, To worship, To give thanks; here's a great deale of service mentioned to God, and yet sure no more than needs. But in the antient Church of the Iewes, was there no Reading, no Preaching of the Law to informe people? Yes, out of question: They heard Moses, \& the Prophets in their Synagogues every Sabbath day, Acts 13. yea, and in the Temple too, if S. Basil be right. But marke then. The Originall Copy of the Law, The word of God written in Tables of Stone, was in the Temple at Ierusalem; And there the Priests, which were to judge according to the Law, Deut. 17. This Law they might and did expound, but they might not crosse with it. No preaching in their severall Synagogues, and Parishes (that I may so terme them,) but was according to the Law, conteined in the Arke, at the Temple, the Mother Church. And 'twas fit. For if every man may preach as he list, though he pretend the Law and the Gospell too, Ierusalem will be quickly out of unity in it selfe. And if they leave comming to the Arke and the Testimony, the world will soone have as many differences in Religion, as there be yong, ignorant, and bold Priests in Parishes."

${ }^{12}$ On the altar rail, see Reeks "“Fair persuasions'?," 185-189, who seeks to offer a corrective to Fincham and Tyacke's Altars Restored: The Changing Face of English Worship, 1547-c.1700 (Oxford: OUP, 2007), which assumes a more rigid enforcement of the altar policy beginning around 1637, as seen in their chapter, 227-73, on the beauty of holiness. For a non-Laud opinion on the beauty of holiness, see Edward Boughen, A Sermon concerning decencie and order in the church (London: 1638), preached on 1 Corinthians 14:40 ("Let all things be done decently, and in order). While Boughen does suggest that it was under Edward VI that 5, "The externe Rites and Ceremonies are APPOINTABLE BY SUPERIOR POWERS; in choosing whereof WE MUST OBEY THE MAGISTRATES" and clarifies, 17, that it is kings and bishops who are those powers, he nevertheless reiterates the party line of Andrewes and Buckeridge that these are to do be done 8 "with due and lowly reverence, as it hath been accustomed" so that, 10, "if a stranger, or unbeleevr should look in upon us (by chance) at our devotions, our reverent and devout demeanor might work ... and winne him to Christ, whom we thus serve, and reverence."

${ }^{13}$ A Speech delivered in the Starr-Chamber (London: 1637). The rhetoric of the Laudian press should not be ignored: Richard Badger was the king's printer, and the title page even dismisses the censure as "pretended innovations in the Church." Nonetheless, the focus here is on what Laud said in his defense, 14, that he was not part of a plot to alter the established religion.

${ }^{14}$ John D. Lewis, transcriber, "A Speech Delivered in the Star Chamber, Concerning Pretended Innovations the Church, 14 June 1637," Project Canterbury,

http://anglicanhistory.org/laud/laud1.html (accessed Jan. 27, 2021).

${ }^{15}$ Prynne, Newes from Ipswich (Ipswich, 1636). The source of the contention comes from II2: they "have cunningly caused all Sermons (the very life and soule of a fast, as being the onely means to humble men for their sins: \& bring them to repe[n]tance,) to be prohibited on the fastday, both in London and the Suburbs, and in al other infected places, during the time of the infection in them." Laud's response, Speech, 17, plays with the title of this Conclusion: individuals "may learn to avoid any visible Inconvenience ... And there was visible Inconvenience observed in mens former flocking to Sermons in Infected places." ${ }^{16}$ Henry Burton, For God, and the King (Amsterdam, 1636). The sermons were November 5 Sermons. 
${ }^{17}$ See Guibbory, Ceremony and Community, 21-2, for her reading of this passage, where Laud "defies not only the word-centered worship of the puritans (and of the Elizabethan and Jacobean church), but also the reformed concept of a physically 'absent' God."

${ }^{18}$ The contemporary echoes are not lost on me.

${ }^{19}$ Burton, For God, 65-6, cites Elizabeth's Uniformity Act which did "publish such further Ceremonies or Rites, as may bee most for the advancement of Gods glory, the edifying of his Church, and the due reverence of Christs holy Mysteries and Sacraments." He continues, "Hereupon they ground all their Innovations ... To bring our new Rites to this Rule. First, doe they make to the Advancement of Gods glory? What? Superstitious, Idolatrous worship, of wooden Aultars ... And do reverence to Christs Sacraments. What? by possessing the people with an opinion of a Popish reall presence? What? by offering Christ in sacrifice upon a Wooden Altar. . . But now our New Reformers are tooth and nayle for setting up Popery againe: witnesse their hoysing up Altars in most places, as also of Images, Crucifixions with adorations, putting downe of the means of knowledge, as Preaching, and bringing in of Ignorance, also preaching for sundry points of Popery." To Burton, the prelates are both putting down sermons while nevertheless using sermons to reintroduce auricular confession, saintly invocation, and prayers for the dead.

${ }^{20}$ A Directory for the Publique Worship of God (London, 1644). As Peter Heylyn notes in The History of the Troubles and Tryal of Laud (London, 1695), 453, January 4, 1644 was the day Parliament passed an ordinance of attainder against Laud and an ordinance banning the use of the $B C P$.

${ }^{21}$ The Directory redresses several concerns raised in this project: bowing and kneeling, 10: "Let all enter the Assembly, not irreverently, but in a grave and seemly manner, taking their seates or places without Adoration, or Bowing themselves towards one place or other"; sitting at the communication table, 50-1: "After this Exhortation, Warning, and Invitation, the Table being before decently covered, and so conveniently placed, that the Communicants may orderly sit about it, or at it"; and festival days, 85: "There is no Day commanded in Scripture to be kept holy under the Gospell, but the Lords day, which is the Christian Sabbath. Festivall daies, vulgarly called Holy daies, having no warrant in the word of God, are not to be continued."

${ }^{22}$ For an "Anglican" take, see the citation of Dauerty in Chapter Three about the DPW ushering in the "dark ages" of the Church of England. Edward P. Elchin, "Was Laud's Liturgy Wholly Laud's?," Historical Magazine of the Protestant Episcopal Church 37.2 (1968): 105-115, explores the "Laudian myth" that the prayerbook, with its distasteful-to-puritan elements, was wholly the work of Laud.

${ }^{23}$ Directory, 4: "In the mean time Papists boasted, that the Book was a compliance with them in a great part of their Service, and so were not a little confirmed in their Superstition and Idolatry, expecting rather our return to them, than endeavouring the Reformation of themselves: In which expectation they were of late very much incouraged, when, upon the pretended warrantablenesse of imposing of the former Ceremonies, new ones were dayly obtruded upon the Church."

${ }^{24}$ See variously Peter Heylyn's response included in The History and Troubles of the Tryals, 447: "The day before they pass'd the Ordinance for Establishing their New Directory; which in effect, was nothing but a total Abolition of the Common-Prayer-Book; and thereby shewed unto the World, how little hopes they had of setling their new Form of Worship, if the Foundation of it were not laid in the Blood of this Famous Prelate, who had so stoutly stood up for it, against all Novellism and Faction, in the whole course of his Life;" Charles's proclamation against the ordinance, published independently, but also included in Henry Hammond's A View of the New Directorie and a Vindication of the Ancient Liturgie (Oxford 1646), which dismisses the manifold inconveniences (6: "There are no such inconveniences") as "pretended names" and defends the Ancient and non-popish lineage of the liturgy.

${ }^{25}$ The Arch-bishop of Canterburie his speech, or His Funeral sermon (London: 1645), 8. 
${ }^{26}$ I specify Jacobean due to the prefatory materials of the $1604 B C P$ revision which reaffirms Cranmer's dedication to the Ancient Church and patristic evidence deemed non-Catholic. Laud gave a similar speech in response to the charges brought against him. In the History and Troubles of the Tryals, he gives the following defense, 156-157 (not a part of his diary): "I never endeavoured to alter or subvert God's true Religion established by Law in this Kingdom; or to bring in Romish Superstition. Neither have I declared, maintained, or Printed any Popish Doctrine, or Opinion, contrary to the Articles of Religion established, or any one of them, either to the end mentioned in this Article, or any other. I have neither urged nor injoyned any Popish or Superstitious Ceremonies without warrant of Law; nor have I cruelly persecuted any Opposers of them. But all that I laboured for in this particular was, that the external Worship of God in this Church, might be kept up in Uniformity and Decency, and in some Beauty of Holiness. And this the rather, because first I found that with the Contempt of the Outward Worship of God, the Inward fell away apace, and Profaneness began boldly to shew it self. And secondly, because I could speak with no conscientious Persons almost, that were wavering in Religion, but the great motive which wrought upon them to disaffect, or think meanly of the Church of England, was, that the external Worship of God was so lost in the Church (as they conceived it;) and the Churches themselves, and all things in them, suffered to lye in such a base and slovenly Fashion in most places of the Kingdom. These, and no other Considerations, moved me to take so much care as I did of it; which was with a single Eye, and most free from any Romish Superstition in any thing. As for Ceremonies; all that I injoyned, were according to Law. And if any were Superstitious, I injoyned them not. As for those which are so called by some Men, they are no Innovations, but Restaurations of the ancient approved Ceremonies, in, and from the beginning of the Reformation, and setled either by Law or Custom; till the Faction of such as now openly and avowedly separate from the Church of England, did oppose them, and cry them down. And for the Censures which I put upon any, I presume they will to all indifferent Men, which will Understandingly and Patiently hear the Cause, appear to be Just, Moderate, and according to Law."

${ }^{27}$ On moderate puritans, see Lake's work by the same title, but also the works of Doerksen. The "hardly representative" judgment is Stanwood's, Sempiternal Season, 113.

${ }^{28}$ While McCullough, "Transforming Passions," 580, identifies Lutheran "as an English Calvinist term of opprobrium" by the 1590 s, in the 1630 s, at least one Laudian preacher named them without condemning them. Boughen, Sermon concerning decencie, 10-11: "When the whole congregation shall appear in the presence of God as one man, decently kneeing, rising, standing, bowing, praising ... like men of one mind and religion in the house of God; as I have heard it credibly reported of the Lutherans." On the role of continental Lutheranism, see the citations of Veith in the Introduction.

${ }^{29}$ This is especially prominent, perhaps, in the reading of Andrewes's 1617 "beauty of holiness" where scholars cite or quote its appearance and assume it conforms with the 1630s stereotype of the campaign just because Andrewes's chapel appeared that way (e.g., Fincham, 281) but disregard how Andrewes discusses the notion in its actual context.

${ }^{30}$ On Donne, see Gimelli Martin, or Guibbory, "Reconsidering Donne," both passim. On Milton, see Parry, Arts of the Anglican Counter-Reformation, 246, McDowell, passim, or Debora Shuger, “Milton's Religion: The Early Years," Milton Quarterly 46.3 (October 2012): 137-53. 


\section{Bibliography}

Abraham, Peter. "The Use of Hierarchy in the Post-Reformation Church: Laudian Altar Policy in the Diocese of Winchester." Anglican and Episcopal History 72.2 (June 2003): 166-96.

Achinstein, Sharon. "Reading George Herbert in the Restoration." English Literary Renaissance 36.3 (2006): 430-65.

Andrewes, Lancelot. A Sermon Preached before His Maiestie, At Whitehall the fift of Nouember last. London: 1617.

Andrewes, Lancelot. A Sermon Preached before his Maiestie at Whitehall, on Easter day last. London: 1618.

Andrewes, Lancelot (with Henry Isaacson). Institutiones Piae or Directions to Pray. London: 1630.

Andrewes, Lancelot. Opuscula Quaedam Posthuma. London: 1629.

Andrewes, Lancelot. The Private Devotions. London: 1647.

Andrewes, Lancelot. Selected Sermons and Lectures. Edited by Peter McCullough. Oxford: OUP, 2005.

Andrewes, Lancelot. XCVI Sermons. London: 1629.

The Arminian Nunnery. London: 1641.

The Articles or, Charge Exhibited in Parliament against D. Cozens of Durham. London: 1641.

“bare, adj., adv., and n.”. OED Online. June 2020. Oxford University Press. https://wwwoed-

com.proxy.mul.missouri.edu/view/Entry/15500?rskey=jft0I4\&result=1\&isAdvan ced=false (accessed June 4, 2020).

Baskerville, S. K. "Puritans, Revisionists, and the English Revolution." Huntington Library Quarterly 61.2 (1998): 151-71.

Bastwick, John. The Answer of John Bastwick. London?: 1637.

Bayly, Lewis. The Practise of Pietie. London: 1613.

Bell, Ilona. "Revision and Revelation in Herbert's 'Affliction (I)."' John Donne Journal 3.1 (1984): 73-96.

Bell, Ilona. "'Setting Foot into Divinity' George Herbert and the English Reformation." Modern Language Quarterly 37 (1977): 219-44.

Bible Gateway. No date. http://biblegateway.org (accessed February 11, 2021).

Bienz, John. "Images and Ceremonial in The Temple: Herbert's Solution to a Reformation Controversy." Studies in English Literature, 1500-1900 26.1 (1986): 73-95.

Blaise, Anne-Marie Miller. "'Sweetnesse readie penn'd': Herbert's Theology of Beauty." George Herbert Journal 27.1/2 (Fall 2003/Spring 2004): 1-21.

Boughen, Edward. A Sermon concerning decencie and order in the church. London: 1638.

Bowers, Fredson. "Herbert's Sequential Imagery: 'The Temper.'” Modern Philology 59.3 (1962): 202-13.

“brave, adj., n., and int.”. OED Online. June 2020. Oxford University Press. https://wwwoed- 
com.proxy.mul.missouri.edu/view/Entry/22790?rskey=JPbYwo\&result=1\&isAdv anced $=$ false (accessed June 4, 2020).

The British Library. English Short Title Catalogue. http://estc.bl.uk/ (accessed February 5, 2021).

Brown, Matthew P. "The Thick Style: Steady Sellers, Textual Aesthetics, and Early Modern Devotional Reading." PMLA 121.1 (2006): 67-86.

Buckeridge, John. A Sermon Preached before His Maiestie At Whitehall, March 22. 1617. being Passion-Sunday, Touching Prostration, and Kneeling in the worship of God. To which is added a Discourse Concerning Kneeling at the Communion. London: 1618.

Burton, Henry. For God, and the King. Amsterdam: 1636.

Burton, Henry. A Tryall of Private Devotions. Or, A Diall for the Houres of Prayer. London: 1628.

Calderwood, David. Perth Assembly. Leiden: 1619.

“canon, n.1”. OED Online. September 2020. Oxford University Press. (accessed November 9, 2020).

Capp, Bernard. "The Religious Marketplace: Public Disputations in Civil War and Interregnum England.” The English Historical Review 129.536 (February 2014): 47-78.

The Church of England. The Booke of Common Prayer, and administration of the sacraments, and other rites and ceremonies of the Church of England. London: 1604.

The Church of England. Constitutions and Canons Ecclesiastical. London: 1604. https://www.anglican.net/doctrines/1604-canon-law (accessed February 10, 2021).

Collinson, Patrick. The Religion of Protestants: The Church in English Society 15591625. Oxford: Clarendon Press, 1982.

Cosin, John. A Collection of Private Devotions. Edited by P.G. Stanwood and Daniel O’Connor. Oxford: Clarendon Press, 1967.

Cosin, John. A Collection of Private Devotions or the Houres of Prayer. London: 1627.

Cosin, John. The Correspondence of John Cosin, vol. 1. Edited by George Ornsby. Durham: Surtee Society, 1829.

Cosin. John. The Works of Bishop Cosin, vol. 1. Edited by John Henry Parker. Oxford: 1843.

Cromartie, Alan. "King James and the Hampton Court Conference" in James VI and I: Ideas, Authority and Government. Edited Ralph Houlbrooke, 61-80. Farnham: Ashgate, 2006.

Cruickshank, Frances. "Broken Altars: The Work of Form in George Herbert's Temple." Christianity \& Literature 66.1 (2016): 24-38.

Cuming, Geoffrey. The Godly Order: Texts and Studies Relating to the book of Common Prayer. London: Alcuin Club/SPCK, 1983.

Cummings, Brian. "Prayer, Bodily Ritual, and Performative Utterance: Bucer, Calvin, and the Book of Common Prayer" in Prayer and Performance in Early Modern English Literature: Gesture, Word and Devotion. Edited by Joseph William Sterrett, 16-36. Cambridge: CUP, 2018. 
Dauerty, J. Shackelford. "The Recovery of Worship (continued)." Journal of the Presbyterian Historical Society (1943-1961) 37.3 (1959): 177-90.

Davies, Julian. The Caroline Captivity of the Church: Charles I and the Remoulding of Anglicanism 1625-1641. Oxford: OUP, 1992.

Demarest, Bruce. The Cross and Salvation: The Doctrine of Salvation. Wheaton, IL: Crossway, 1996; 2006 ebook edition.

Dering, Edward. A Collection of Speeches Made by Sir Edward Dering Knight and Baronet, in Matter of Religion. London: 1642.

Dighton, Thomas. Certain Reasons of a Private Christian Against Conformitie to kneeling in the very act of receiving the Lords Supper. Leiden: 1618.

A Directory for the Publique Worship of God. London: 1644.

Dominiak, Paul Anthony. Richard Hooker: The Architecture of Participation. London: T\&T Clark: 2020.

Donne, John. The Oxford Edition of the Sermons of John Donne, vol. III. Edited by David Colclough. Oxford, OUP: 2014.

Doerksen, Daniel W. Conforming to the Word: Herbert, Donne, and the English Church before Laud. Lewisburg: Bucknell UP, 1997.

Doerksen, Daniel W. "George Herbert, Calvinism, and Reading 'Mattens'.” Christianity \& Literature 59.3 (2010): 437-451.

Doerksen, Daniel W. “The Laudian Interpretation of George Herbert.” Literature and History 3.2 (1994) 36-54.

Doerksen, Daniel W. Picturing Religious Experience: George Herbert, Calvin, and the Scriptures. Newark: University of Delaware Press, 2011.

Doerksen, Daniel. "Preaching Pastor Versus Custodian of Order: Donne, Andrewes, and the Jacobean Church." Philological Quarterly 73.4 (1994): 417-29.

Doerksen, Daniel and Christopher Hodgkins, eds. Centered on the Word: Literature, Scripture, and Tudor-Stuart Middle Way. Newark: University of Delaware Press, 2004.

Dowden, Edward. Puritan and Anglican: Studies in Literature. London: Kegan Paul, Trench, Trubner, 1900.

Dyck, Paul. "Altar, Heart, Title-Page: The Image of Holy Reading." English Literary Renaissance 43.3 (Autumn 2013): 541-571.

"Easter Hymn." Catholic Culture. 2021. https://www.catholicculture.org/culture/library/view.cfm?recnum=124 (accessed February 23, 2021).

Edlin, T. P. J. "Tymme, Thomas (d. 1620), translator and devotional writer." Oxford Dictionary of National Biography. 23 Sep. 2004; (accessed December 8, 2020).

Elchin, Edward P. "Was Laud's Liturgy Wholly Laud's?” Historical Magazine of the Protestant Episcopal Church 37.2 (1968): 105-115.

Featley, Daniel. Ancilla Pietatis: Or, the Hand-Maid to Private Devotion. London: 1626.

Featley, Daniel. The Summe of Saving Knowledge: Delivered in a Catechisme, consisting of fifty two Sections answerable to the Sabbaths throughout the Yeere. London: 1626.

Fincham, Kenneth and Nicholas Tyacke. Altars Restored: The Changing Face of English Worship, 1547-c.1700. Oxford: OUP, 2007. 
Fincham, Kenneth. Prelate as Pastor: The Episcopate of James I. Oxford: Clarendon Press, 1990.

Fish, Stanley. The Living Temple: George Herbert and Catechizing. Berkeley: University of California Press, 1978.

Ferrell, Lori Anne. Government by Polemic: James I, the King's Preachers, and the Rhetoric of Conformity, 1603-1625. Palo Alto: Stanford UP, 1998.

Garrett, Cynthia. "The Rhetoric of Supplication: Prayer Theory in Seventeenth-Century England." Renaissance Quarterly 46.2 (Summer 1993): 328-57.

Gibbs, Lee W. "Richard Hooker and Lancelot Andrewes on Priestly Absolution" in Richard Hooker and the Construction of Christian Community. Edited Arthur Stephen McGrade, 261-274. Tempe, AZ: Medieval \& Renaissance Texts \& Studies, 1997.

Gibson, William. "The British Sermon 1689-1901: Quantities, Performance, and Culture" in The Oxford Handbook of the British Sermon 1689-1901. Edited by Keith Francis, et al., 3-30. Oxford: OUP, 2012.

Gimelli Martin, Catherine. "Experimental Predestination in Donne's Holy Sonnets: SelfMinistry and the Early Seventeenth-Century 'Via Media."' Studies in Philology 110.2 (2013): 350-81.

Greaves, Richard. Society and Religion in Elizabethan England. Minneapolis: University of Minnesota Press, 1981.

Greek Concordances. BibleHub.com https://biblehub.com/greek/ (accessed February 22, 2021).

Green, Ian. The Christian's ABC: Catechisms and Catechizing in England c. 1530-1740. Oxford: Clarendon Press, 1996.

Green, Ian. Print and Protestantism in Early Modern England. Oxford: OUP, 2000.

Guibbory, Achsah. Ceremony and Community from Herbert to Milton: Literature, Religion, and Cultural Conflict in Seventeenth-century England. Cambridge: CUP, 1998.

Guibbory, Achsah. "Devotional Poetry and the Temple of God." George Herbert Journal 37.1 (2013): 99-116.

Guibbory, Achsah. "Reconsidering Donne: From Libertine Poetry to Arminian Sermons." Studies in Philology 114.3 (Summer 2017): 561-590.

Guruswamy, Rosemary Fithian. "The Sweet Defender of New England.” The New England Quarterly 63.2 (1990): 294-302.

Guyer, Benjamin. "Review: 'This Great Firebrand': William Laud and Scotland 16171645. Studies in Modern British History by Leonie James." Anglican and Episcopal History 88.2 (2019): 210-12.

Hamlin, Hannibal. Psalm Culture and Early Modern English Literature. Cambridge: CUP: 2004.

Hammond, Henry. A View of the New Directorie and a Vindication of the Ancient Liturgie. Oxford: 1646.

Hampton, Stephen. “'Welcome Dear Feast of Lent': Rival Understandings of the Fortyday Fast in Early Stuart England" The Journal of Theological Studies 63.2 (2012): 608-48.

Hanley, Sara William. "Temples in The Temple: George Herbert's Study of the Church.” Studies in English Literature, 1500-1900 8.1 (1968): 121-35. 
Hanson, L.W. “John Cosin's Collection of Private Devotions, 1627." The Library 13.5 (1958): 282-87.

"Henry Tozer (1602-1650): A Puritan minister, and member of the Westminster Assembly." A Puritan's Mind, 2021. https://www.apuritansmind.com/puritanfavorites/henry-tozer-1602-1650/ (accessed February 17, 2021).

Herbert, George. The Complete Poetry. Edited by John Drury and Victoria Moul. New York: Penguin, 2015.

Herbert, George. The English Poems of George Herbert. Edited by Helen Wilcox. Cambridge: CUP, 2007.

Herbert, George. A Priest to the Temple, or: The Countrey Parson. London: 1652.

Herle, Charles. Ahab's Fall by his Prophets Flatteries. London: 1644.

Herle, Charles. Contemplations and Devotions on the several passages of our blessed Saviors Death and Passion. London: 1631.

Herrick, Robert. The Complete Poetry of Robert Herrick. Edited by J. Max Patrick. New York: W.W. Norton, 1968.

Heylyn, Peter. The History of the Troubles and Tryal. London: 1695.

Hill, Christopher A. “George Herbert's Sweet Devotion.” Studies in Philology 107.2 (2010): 236-58.

Hodgkins, Christopher. "'Betwixt This World and That of Grace': George Herbert and the Church in Society." Studies in Philology 87.4 (1990): 456-75.

Hodgkins, Christopher. "The Church Legible: George Herbert and the Externals of Worship." The Journal of Religion 71.2 (1991): 217-41.

Hooker, Richard. The Works of that Learned and Judicious Divine Mr. Richard Hooker with an Account of His Life and Death by Isaac Walton, vol. 2. Edited by John Keble. Oxford: Clarendon Press, 1888, $7^{\text {th }}$ edition. (accessed February 1, 2021). https://oll.libertyfund.org/title/keble-the-works-of-richard-hooker-vol-2.

Hunt, Arnold. Art of Hearing: English Preachers and their Audiences, 1590-1640. Cambridge: CUP, 2010.

Hunt, Arnold. "Featley [Fairclough], Daniel (1582-1645), Church of England clergyman and religious controversialist." Oxford Dictionary of National Biography. OUP: 23 Sep. 2004; (accessed February 11, 2021).

Hunt, Arnold. “The Lord's Supper in Early Modern England." Past \& Present 161 (1998): 39-83.

Hunt, Arnold. "Shelford, Robert (c. 1563-1638/9), Church of England clergyman and religious writer." Oxford Dictionary of National Biography. OUP: 23 Sep. 2004. (accessed September 9, 2020).

“IHS, n.”. OED Online. September 2020. Oxford University Press. https://www-oedcom.proxy.mul.missouri.edu/view/Entry/91271?redirectedFrom=ihs (accessed November 2, 2020).

James, Anne. Poets, Players, and Preachers: Remembering the Gunpowder Plot in Seventeenth-Century England. Toronto: University of Toronto Press, 2016.

Janacek, Bruce. "Thomas Tymme and Natural Philosophy: Prophecy, Alchemical Theology, and the Book of Nature." The Sixteenth Century Journal 30.4 (1999): 987-1007.

Jeffrey, David Lyle. In the Beauty of Holiness: Art and the Bible in Western Culture. Grand Rapids, MI: William B. Eerdmans Publishing Company, 2017. 
Jones, J. Gwynfor and Viviene Larminie. "Bayly, Lewis, (c. 1575 - 1631)," Oxford Dictionary of National Biography. OUP: 2004 and 2008 (accessed February 22, 2020).

Klemp, P. J. "Lancelot Andrewes, Plagiarism, and Pedagogy at Hampton Court in 1606," Philological Quarterly, 77.1 (1998): 15-33.

Knapp, James. Immateriality and Early Modern English Literature: Shakespeare, Donne, Herbert. Edinburgh: Edinburgh UP, 2020.

Knight, Alison. "The Odious Original: Andrewes and Scriptural Indecorum.” Paper presented at the Lancelot Andrewes and Early Modern Religious Culture Conference. March 26, 2021.

Kronenfeld, Judy Z. "Probing the Relationship between Poetry and Ideology: Herbert's 'The Windows.'” John Donne Journal 2.1 (1983): 55-80.

Lake, Peter. Anglicans and Puritans? Presbyterian and English Conformist Thought from Whitgift to Hooker. London: Unwin Hyman, 1988.

Lake, Peter. "Calvinism and the English Church 1570-1635." Past \& Present 114 (1987): 32-76.

Lake, Peter. "Lancelot Andrewes, John Buckeridge, and the Avant-Garde Conformity at the court of James I" in The Mental World of the Jacobean Court. Edited by Linda Levy Peck, 113-33. Cambridge: CUP, 1991.

Lake, Peter. "The Laudian Style: Order, Uniformity and the Pursuit of the Beauty of Holiness in the 1630s" in The Early Stuart Church, 1603-1642. Edited by Kenneth Fincham, 161-185. London: Palgrave, 1993.

Lake, Peter and Michael Questier. The Anti-Christ's Lewd Hat: Protestants, Papists and Players in Post-Reformation England. New Haven, CT: Yale UP, 2002.

Lambert, Sheila. "Richard Montagu, Arminianism and Censorship." Past \& Present, 124 (1989): 36-68.

Lane, Calvin. The Laudians and the Elizabethan Church: History, Conformity, and Religious Identity in Post-Reformation England. London: Pickering \& Chatto Publishers, 2013.

Larminie, Vivienne. "Herle, Charles," Oxford Dictionary of National Biography, OUP: 25 May 2006.

Larminie, Vivienne. “Tozer, Henry,” Oxford Dictionary of National Biography, OUP: 03 January 2008.

Laud, William. The Arch-bishop of Canterburie his speech, or, His funeral sermon preached by himself on the scaffold of Tower-hill on Friday the tenth of January. London: 1645.

Laud, William. Seven Sermons Preached upon Severall Occasions by the Right Reverend and Learned Father in God, William Laud, late Arch-Bishop of Canterbury. London: 1651.

Laud, William. A Speech Delivered in the Starr-Chamber. London: 1637.

Laud, William. "A Speech Delivered in the Star Chamber, Concerning Pretended Innovations in the Church, 14 Jun 1637." Edited by John D. Lewis, Project Canterbury. http://anglicanhistory.org/laud/laud1.html (accessed January 27, 2021).

"Laudian, adj. and n.". OED Online. June 2020. Oxford University Press. https://wwwoed- 
com.proxy.mul.missouri.edu/view/Entry/106239?redirectedFrom=laudianism. (accessed July 21, 2020).

Lewalksi, Barbara. Protestant Poetics and the Seventeenth-Century Religious Lyric. Princeton: Princeton UP, 1979.

MacCulloch, Diarmaid. "Richard Hooker's Reputation." The English Historical Review 117. 473 (2002): 773-812.

MacKenzie, Iain. God's Order and Natural Law: The Works of the Laudian Divines. Farnham: Ashgate, 2002.

Maltby, Judith. Prayer Book and People in Elizabethan and Early Stuart England. Cambridge: CUP, 1998.

Martz, Louis. The Poetry of Meditation: A Study in English Religious Literature of the Seventeenth Century. New Haven: Yale University Press, 1954 (1962 reprint).

"matins, n.". OED Online. June 2020. Oxford University Press. https://www-oedcom.proxy.mul.missouri.edu/view/Entry/114993?rskey=PVhAlD\&result=2\&isAd vanced=false (accessed July 6, 2020).

McCullough, Peter. "Absent Presence: Lancelot Andrewes and 1662," in Comfortable Words: Polity, Piety, and the Book of Common Prayer. Edited by Stephen Platten and Christopher Wood, 49-68. London: SCM Press, 2012.

McCullough, Peter. "Andrewes, Lancelot (1555-1626), bishop of Winchester. Oxford Dictionary of National Biography. January 03, 2008. OUP.

McCullough, Peter. "Buckeridge, John (d. 1631), bishop of Ely." Oxford Dictionary of National Biography. January 03, 2008. OUP.

McCullough, Peter. "Making Dead Men Speak: Laudianism, Print, and the Works of Lancelot Andrewes, 1626-1642." The Historical Journal 41. 2 (June 1, 1998): 401-24.

McCullough, Peter. "Lancelot Andrewes's Transforming Passions." Huntington Library Quarterly 71.4 (2008): 573-89.

McCullough, Peter. Sermons at Court, 1559-1625: Religion and Politics in Elizabethan and Jacobean Preaching. Cambridge: CUP, 1998.

McDowell, Nicholas. "How Laudian was the Young Milton?” Milton Studies 52 (2011): 3-22, 253-256.

McGrath, Patrick J. "Reconsidering Laud: Puritans and Anglican Asceticism." Prose Studies 34.1 (April 2012): 32-49.

McGovern, Jonathan. "The Political Sermons of Lancelot Andrewes." The Seventeenth Century 34.1 (2019): 3-25.

McLaughlin, Elizabeth and Gail Thomas. "Communion in The Temple." Studies in English Literature, 1500-1900 15.1 (1975): 111-124.

McQuade, Paula. Catechisms and Women's Writing in Seventeenth-Century England. Cambridge: CUP, 2017.

Middleton, Arthur. Fathers and Anglicans: The Limits of Orthodoxy. London: Gracewing, 2001.

Milton, Anthony, "Arminians, Laudians, Anglicans, and Revisionists: Back to Which Drawing Board?" Huntington Library Quarterly 78.4 (2015): 723-742.

Milton, Anthony. Catholic and Reformed: The Roman and Protestant Churches in English Protestant Thought, 1600-1640. Cambridge: CUP, 1995. 
Milton, Anthony. "Laud, William (1573-1645), archbishop of Canterbury." Oxford Dictionary of National Biography. 23 Sep. 2004. https://doiorg.proxy.mul.missouri.edu/10.1093/ref:odnb/16112 (accessed March 3, 2021).

Morrissey, Mary. "Interdisciplinarity and the Study of Early Modern Sermons." The Historical Journal 42:2 (1999): 1111-1123.

Morrissey, Mary. Politics and the Paul's Cross Sermons, 1558-1642. Oxford: OUP, 2011.

Morton, Thomas. A Defence of the Innocencie of the Three Ceremonies of the Church of England. London: 1618.

Myers, Anne. "Restoring 'The Church-porch': George Herbert's Architectural Style." English Literary Renaissance 40.3 (2010): 427-57.

Narveson, Kate. "Flesh, Excrement, Humors, Nothing: The Body in Early Stuart Devotional Discourse." Studies in Philology 96.3 (1999): 313-333.

Overall, John. Articles to be Enquired of in the Diocesse of Norwich. London: 1619.

The Oxford History of Anglicanism, Volume 1: Reformation and Identity, c.1520-1662. Edited by Anthony Milton. Oxford: OUP, 2017.

Parry, Graham. The Arts of the Anglican Counter-Reformation: Glory, Laud and Honour. Rochester, NY: Boydell \& Brewer, 2006.

Parry, Graham. "The Tradition of High Church Prayer in the Seventeenth Century" in Prayer and Performance in Early Modern Literature: Gesture, Word, and Devotion. Edited by Joseph William Sterrett, 37-49. Cambridge: CUP, 2018.

Patrick, J. Max. The Editor as Critic and the Critic as Editor. Los Angeles, CA: William Andrews Clark Memorial Library, 1973.

Perkins, William. The Arte of Prophecying, or, A Treatise Concerning the Sacred and Onely True Manner and Methode of Preaching. London: 1607.

Perkins, William. A Golden Chaine, or the Description of Theology Containing the Order of the Causes of Salvation and Damnation, According to Gods Woord. London: 1591.

Poch, John. "Birds of a Feather: George Herbert's "Easter-wings.” Christianity \& Literature 68.3 (2019): 475-490.

“precept, n.”. OED Online. September 2020. Oxford University Press. https://www-oedcom.proxy.mul.missouri.edu/view/Entry/149594?rskey=SYy7UH\&result=1\&isA dvanced=false (accessed November 9, 2020).

Prynne, William. A Briefe Survay and Censure of Mr Cozens his Couzening Devotions. London: 1628.

Prynne, William. Newes from Ipswich. Ipswich: 1636.

The Psalms of Sir Philip Sidney and the Countess of Pembroke. Edited by J.C.A Rathmell. New York: Anchor Books, 1963. Digitized by the Internet Archive.

Quantin, Jean-Louis. The Church of England and Christian Antiquity: The Construction of a Confessional Identity in the 17 th Century. Oxford: OUP, 2009.

Rastell, John. A confutation of a sermon, pronounced by M. Iuell, at Paules Crosse, the second Sondaie before Easier (which Catholikes do call Passion Sondaie. Antwerp: 1564.

Reeks, John. "'Fair Persuasions'? The Implementation of Laudian Altar Policy in the Diocese of Bath and Wells." Reformation 23.2 (2018): 175-190. 
"Regeneration (theology)." Wikipedia. 2020.

https://en.wikipedia.org/wiki/Regeneration_(theology) (accessed July 6, 2020).

Richards, Jennifer, and Fred Schurink. "Introduction: The Textuality and Materiality of Reading in Early Modern England." Huntington Library Quarterly 73.3 (2010): $345-61$.

"resort, v.1". OED Online. June 2020. Oxford University Press. https://www-oedcom.proxy.mul.missouri.edu/view/Entry/163756?rskey=J6nryy\&result=2 (accessed June 4, 2020).

Ryrie, Alec. "The Afterlife of Lutheran England" in Sister Reformations: The Reformation in Germany and England - Schwesterreformationen Die Reformation in Deutschland und in England. Edited by Dorothea Wendebourg and Alec Ryrie, 213-234. Tübingen: Mohr Siebeck, 2010.

Ryrie, Alec. Being Protestant in Reformation England. Oxford, OUP: 2013.

Ryrie, Alec. "The Strange Death of Lutheran England." The Journal of Ecclesiastical History 53.1 (2002): 64-92.

Salazar, Gregory. "Daniel Featley and Calvinist Conformity in Stuart England." PhD diss., University of Cambridge, 2018.

"Salve Festa Dies." Hymn Descants.org. April 2019. https://hymndescants.org/salvefesta-dies (accessed February 23, 2021).

Sechler, Michael J., and Janelle Greenberg. " "There is Scarce a Pamphlet that doth not Triumph in Bracton': The Role of 'de legibus et consuetudinibus angliae" in Stuart Political Thought." History of Political Thought 33.1 (2012): 25-54.

Shelford, Robert. Five Pious and Learned Discourses. Cambridge: 1635.

"Shell." Catholic Culture, 2021, https://www.catholicculture.org/culture/library/dictionary/index.cfm?id=36454 (accessed February 23, 2021).

Shuger, Debora K. Habits of Thought in the English Renaissance: Religion, Politics, and the Dominant Culture. Toronto: University of Toronto Press, 1997.

Shuger, Debora K. "Milton's Religion: The Early Years." Milton Quarterly 46.3 (October 2012): 137-53.

Sparke, Michael. Crumms of Comfort, The Valley of Tears, and The Hill of Joy. London: 1627.

Spinks, Bryan D. The Rise and Fall of the Incomparable Liturgy: The Book of Common Prayer, 1559-1906. London: SPCK, 2017.

Spinks, Bryan D. Sacraments, Ceremonies and the Stuart Divines: Sacramental theology and liturgy in England and Scotland 1603-1662. Farnham: Ashgate, 2002.

Smart, Peter. A Sermon Preached in the Cathedral Church of Durham, July $7^{\mathrm{t}} 1628$. London(?): 1640.

Stanwood, P.G. Sempiternal Season: Studies in Seventeenth-Century Devotional Writing. New York: Peter Lang, 1992.

Stewart, Laura. "'Brothers in Treuth': Propaganda, Public Opinion and the Perth Articles Debate in Scotland" in James VI and I: Government, Authority and Ideas. Edited by Ralph Houlbrooke, 151-68. Farnham: Ashgate, 2006.

Stewart, Laura. "The Political Repercussions of the Five Articles of Perth: A Reassessment of James VI and I's Religious Policies in Scotland." The Sixteenth Century Journal 38:4 (2007): 1013-36. 
Stranks, C.J. Anglican Devotion: Studies in the Spiritual Life of the Church of England between the Reformation and the Oxford Movement. London: SCM Press, 1961.

Strier, Richard. "George Herbert and Ironic Ekphrasis." Classical Philology 102.1 (2007): 96-109.

Strier, Richard. Love Known: Theology and Experience in George Herbert's Poetry. Chicago: University of Chicago Press, 1983.

Swanner, Seth. "The Beauty of Ho(me)liness: The Unhandsome Sacramentality of Almost-Shape Poems in George Herbert's The Temple." Studies in Philology 115. 3 (2018): 544-79.

Taylor, Jeremy. A Collection of Offices or Forms of Prayer. London: 1657.

Taylor, Jeremy. The Worthy Communicant. London: 1667.

“Thomas Tymme.” Wikipedia. 2 October 2019. https://en.wikipedia.org/wiki/Thomas_Tymme (accessed December 8, 2020).

Tozer, Henry. Directions for a Godly Life: Especially for Communicating at the Lord's Table. Oxford: 1628.

Trevor-Roper, Hugh. Catholics, Anglicans, and Puritans: Seventeenth Century Essays. London: Martin Secker \& Warburg, 1987.

Tuve, Rosemond. A Reading of George Herbert. Chicago: University of Chicago Press, 1952.

Tyacke, Nicholas. Anti-Calvinists: The Rise of English Arminianism c. 1590-1640. Oxford: Clarendon Press, 1987 [1991 reprint].

Tymme, Thomas. A Chariot of Devotion. London: 1618.

Tymme, Thomas. The Figure of Antichrist. London: 1586.

Tymme, Thomas. The Poor Mans Pater Noster. London: 1598, second impression.

Tymme, Thomas. Preparation against the Prognosticated Dangers of this Year. London: 1588.

Tymme, Thomas. A Silver Watch-bell. London: 1605.

Valentine, Henry. Private Devotions digested into Six Letanies. London: 1631.

Vallance, Edward. "Preaching to the Converted: Religious Justifications for the English Civil War." Huntington Library Quarterly 65, no. 3/4 (2002): 395-419.

Van Wengen-Shute, Rosemary. George Herbert and the Liturgy of the Church of England. Drukkerij de Kempenaer: Oegstgeest, 1981.

Veith Jr., Gene. E. Reformation Spirituality: The Religion of George Herbert. Eugene: Wipf \& Stock: 2013 (reprint of Associated University Presses, 1985).

Veith Jr., Gene E. "The Religious Wars in George Herbert Criticism: Reinterpreting Seventeenth-century Anglicanism." George Herbert Journal 11.2 (1988): 19-35.

Waldron, Thomas. "The Sign of the Scallop Shell." The Furrow 30.10 (1979): 646-49.

Watt, Tessa. Cheap Print and Popular Piety, 1550-1640. Cambridge: CUP, 1993.

Whalen, Robert. "George Herbert's Sacramental Puritanism” Renaissance Quarterly 51.4 (2001): 1273-1307.

White, Helen. English Devotional Literature, 1600-1640. University of Wisconsin Studies in Language and Literature 29. Madison: University of Wisconsin Press, 1931.

White, Helen. The Tudor Books of Devotion. Madison: University of Wisconsin Press, 1951. 
Wilkinson, Robert. Barwick Bridge: or England and Scotland coupled. In a sermon tending to peace and unitie. London: 1617.

Wood, Chauncey. "Solomon's Temple, "The British Church," and the Central Role of the Heart in The Temple." George Herbert Journal 35.1/2 (Fall 2011/Spring 2012), 127-141.

Yamamoto-Wilson, John R. "The Protestant Reception of Catholic Devotional Literature in England to 1700." Recusant History 32.1 (2014): 367-390.

Yearwood, Stephenie. "The Rhetoric in The Temple." Studies in English Literature, 1500-1900 23.1 (1983): 131-44. 


\section{VITA}

Travis Knapp was born to a Catholic father and a Lutheran mother. Naturally, as his interests in literature and history grew, he gravitated toward the Protestant Reformation. After spending a majority of his childhood in Fort Smith, Arkansas, Travis attended Oklahoma State University in Stillwater, Oklahoma where he majored in English and History, earning honors degrees in both. It was there he met Dr. Edward Jones, who would go on to spark his interest in the early modern period and supervise an honors thesis on the King James Bible, just after the $400^{\text {th }}$ anniversary of its initial publication. A few years later, in his first graduate seminar at the University of Missouri, Travis kept coming across the name Lancelot Andrewes in the writings of T.S. Eliot (familiar because of the bishop's work in translating the King James Bible), which led him to research the influence of Anglicanism on Eliot's career and write a master's thesis on one of Andrewes's initial sermon publications. This project led into an interest in Laudian thought, which manifested in this dissertation project along with an interest in genre and form. Travis's other research interests include satire, classical reception, and rhetoric. 